


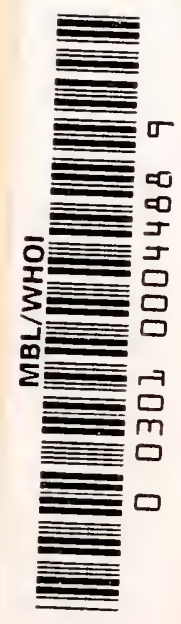







\section{SCIENCE AND HUMAN}

\section{AFFAIRS}

FROM THE VIEWPOINT OF BIOLOGY

BY

WINTERTON C. CURTIS, Ph.D.

PROFESSOR OF ZOÖLOGY IN THE UNIVERSITY OF MISBOUR

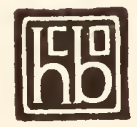

NEW YORK

HARCOURT, BRACE AND COMPANY

1922 
COPYRIGHT, 1922, BY HARCOURT, BRACE AND COMPANY, INC.

Printed in the U. S. A. 
TO THE MEMORY OF MY FATHER WILLIAM CONWAY CURTIS

WHO THROUGHOUT A LONG LIFE EXEMPLIFIED THE SPIRIT OF THE OPEN MIND 



\section{PREFACE}

The present volume sets forth certain of the humanistic aspects of natural science with illustrations largely from the field of biology. The work is an outcome of the author's experience as a teacher of zoölogy, although much that is here contained forms no part of routine zoölogical instruction. The interest of college students in the broader aspects of science, as viewed by the biologist, leads him to believe that the matter presented may interest a wider audience. We often hear the statement that "we live in a scientific age." But what does this mean historically, and what does it imply for the future? Again, it is said that the present is a period of "readjustment." Readjustment to what, and because of what? The present volume seeks in a modest way to answer these questions. The writer has also found an incentive in his conviction that the world has arrived at an age of science, that the necessary readjustments have not been completed and that the future belongs to the scientific frame of mind.

Acknowledgments are due to many friends and associates who have consciously or unconsciously contributed to the work during the course of numerous discussions. Among my fellow zoölogists, who have read extended portions of the manuscript and made valuable suggestions, are Caswell Grave, F. B. Isely, the late W. E. Kellicott, E. G. Conklin, S. O. Mast, and George Lefevre. I am particularly indebted to Professor George Twiss of the Ohio State University, and to Professor A. H. R. Fairchild of the University of Missouri, for the critical reading of preliminary drafts. But most of all, I am under obligation to my friend and colleague Professor N. M. Trenholme for his reading of earlier and later drafts of certain chapters, as well as the final manuscript. 
His constructive criticism of all phases of the work has been of inestimable service. Thanks are also due to Mr. George T. Kline, biological artist of the University of Missouri, for the drawing of Figs. 28, 29, and 30, and for assistance with some of the other figures.

Formal acknowledgments are due to the Scientific American for Fig. 7; to the Clarendon Press for Fig. 8; to the Pierpont Morgan Library, as the source of Fig. 9, reproduced from the paper by W. A. Locy; to the Macmillan Company for the reproduction of Figs. 23 and 24, and for the quotation from Metcalf's "Organic Evolution," as it appears on page 61; to the American Museum of Natural History and the F. A. Stokes Company for Fig. 25; and to Henry Holt and Company for the tabulation of the linked characters in Drosophila, which appears on page 133. Lesser quotations from copyrighted works are duly acknowledged in the footnotes.

W. C. C.

University of Missouri,

Nov. 10, 1921. 


\section{CONTENTS}

\section{PART I}

The History and Significance of Science

CHAPTER

PAGE

I. Thie Meaning of Science to Mankind .......... 3

II. The Origins of Science in the Ancient World. 11

III. The Decline of Ancient Learning . . . . . . . . . . 42

IV. The Emergence of Modern Science. . . . . . . . 66

V. The Further Growth of Science. . . . . . . . . . . 94

\section{PART II}

\section{The Science of Biology}

VI. The Biological Science of the Modern Period: The Cell-Doctrine. . . . . . . . . . . . . . . . 119

VII. The Biological Science of the Modern Period:

The Theory of Organic Evolution......... 155

VIII. Current Problems and Methods of Zoölogical SCIENCE. . . . . . . . . . . . . . . . . . 187

\section{PART III}

The Present Importance of Science

IX. Philosophical and Psychological Aspects of Science. . . . . . . . . . . . . . . . . . . . . . . . . 223

X. The Nature and Meaning of Scientific Research 242 XI. The Rôle of Science in the Solution of Social Problems. . . . . . . . . . . . . . . . . . . . 263

XII. The Higher Values of Science. . . . . . . . . . . . . 290

XIII. Mankind and the Further Progress of Science . 314

INDEX . . . . . . . . . . . . . . . . . . . . . 321

vii 



\section{PART I}

THE HISTORY AND SIGNIFICANCE OF SCIENCE 



\section{CHAPTER I}

\section{THE MEANING OF SCIENCE TO MANKIND}

Science is the product of human reason applied to the phenomena of nature. It is, therefore, as old as rational thought. The straight-thinking man was always a scientist. The minor facts of science, which arise from the interpretation of simple phenomena, have been apprehended from the beginning, though not subjected to critical examination. The major facts of science, which are called scientific laws, and conscious analysis of the methods by which such laws are discovered have been acquired within the period of recorded history. Comprehending at last the meaning of natural knowledge, man has discovered during the recent centuries, the network of relationships which constitutes modern science. But the foundations of science have existed since the dawn of rationality.

Organized science, although it seems so recent a product of the human understanding, may be recognized in its beginnings at an earlier time than is commonly supposed. Reason is constantly striving to bring order out of seeming chaos. This undertaking is not of recent origin. Stripped of their purely mythological features, primitive cosmogonies are comparable to the larger groupings of fact which characterize modern scientific knowledge. Those who believed the earth to be flat were making what was essentially a scientific generalization, so long as it conformed to the appearance of things. Among the Egyptians, the Babylonians, and related peoples, the germs of the physical, astronomical, mathematical, and medical sciences made their appearance at an early date. Among the ancient Greeks, the scientific spirit is discernible, despite the limitations imposed by ignorance, superstition, and unbridled speculation. Among the Euro- 
pean peoples, during the Middle Ages, science was obscured by theological dogma and by the loss of most of the ancient learning. During the Modern Period, which might be termed the Scientific Period, science has become an organized endeavor of overwhelming importance. It has entered its growth-period and has become, with amazing rapidity, the most influential factor in the thought and action of the modern world.

The dominant influence which science now exercises in western culture is a natural outcome of the spectacular changes wrought by science upon the environment of man. Within less than two hundred years, man has succeeded in controlling the conditions of his existence to an extent hitherto unthinkable. The material effects of this new power are seen wherever "the destroying hand of economic civilization" does its work. It is this deplorable aspect of science which has captured the popular imagination. But science has gone deeper. Human thinking has been revolutionized by scientific knowledge and method. It is this spiritual aspect of modern science that is its most significant feature. By comparison, the material aspect is insignificant. So profound, so comprehensive, and so rapid have been the transformations in human thought in modern times, that even scientists have been forced often to change their point of view over night. The end of the revolution, which has thus been forced upon the world, is not yet apparent. Its effects are spreading, its advance shows no signs of abatement, its ultimate results are incalculable. Extensive as the material transformations have been, thrilling as the conquest of physical nature has been, they are surpassed in importance by the changes in human thought. Modern thought is the outcome of modern science. The scientific habit of mind is the unpredictable factor in the life of mankind to-day. Its possibilities for the future defy all estimate or prophecy. The spiritual revolution wrought by scientific thought is illustrated in the changing concept of authority. Suffi- 
cient medievalism survives to enable us to appreciate the intellectual atmosphere which existed in Europe from the decline of the Greco-Roman culture to the dawn of the Renaissance. For more than a thousand years, the final authority, in temporal as in spiritual matters, was scriptural phraseology and the traditional teachings of the masters of antiquity. The writings of Galen were law in human anatomy; the Bible was regarded as a trustworthy textbook in natural history. This condition of mind was an outcome of the enthronement of authoritative statement in the place of critical judgment. It reflected the theological doctrine of authority inherent in every phrase of a Scripture conceived to be inspired. In contrast to this manner of thinking, science recognizes only nature as the ultimate authority in the interpretation of nature. Facts, which any one may verify for himself, are the justifications for the authoritative statements of science. Insensibly, the popular mind is reaching this scientific concept. The older authority may stand, apparently well buttressed and secure, but in reality it has been undermined by the progressive recognition of the authority of nature.

The craftsman of the Middle Ages never doubted the reality of the universe depicted by theology. Performing all the labor incident to the creation of a finished product out of raw material, he could think in terms of a Deity who had made man with $\mathrm{His}$ hands and who arbitrarily changed the course of nature. The modern industrial worker, who performs a small part of the process incident to factory output, and whose universe is the universe of scientific fact, is more likely to regard himself as controlling and directing forces of nature which are represented in his machine. This latter point of view has its limitations and calls for corrective treatment, lest the individual engaged in industry come to regard himself as merely a cog in a mechanism. But it is accomplishing one beneficial result. It is instilling into the worker's mind, and so into the minds of all mankind, the 
idea of natural causation; and once this idea becomes a major factor in human thinking, nature will become for all time the one and only source of authority in explaining phenomena. Even unconsciously, the workman feels the worthlessness of authoritative knowledge of the older sort, and thus stands with the scientist, who regards the traditional explanations as negations of a rational explanation of the world.

Recent tendencies in education further illustrate the influence of this changing concept of authority. The asceticism and scholasticism of the Middle Ages gave way before the humanism of the Renaissance. The new ideal found its counterpart in the thought of ancient times. The literature of Greece and Rome was ardently studied and read for its humanistic values. Latin, being already the language of the learned, became one vehicle of the new philosophy. Greek, being the only pathway to the elder source of European humanism, assumed a corresponding importance. Thus Latin and Greek became associated with modern humanistic philosophy, a union which has been maintained until the present day. The teaching of the Greek and Latin languages per se assumed a commanding position in the educational scheme of western Europe, and was maintained therein long after the original need for such teaching had disappeared. But the authority of tradition, voiced by the pronouncements of classical scholars, no longer convinces. The public in general, and the leaders of education in particular, have turned from the authority of custom to that of psychology, of pedagogy, and of everyday experience. The claim that humanistic values inhere within the very languages of Greece and Rome must rest upon a more secure foundation than educational tradition, if Greek and Latin continue as vital elements in general education.

The authority in education from now on must be scientific authority. We are still profoundly ignorant of what constitutes scientific procedure within so complex a field. We 
shall discover this procedure only by long and painstaking study. Merely to have changed time-honored standards is no guarantee that the new ones are final. If analysis of educational experience shows that the only road to an understanding of the ancient humanism lies through the original languages, and if it appears, as a further result of scientific analysis, that herein lies the greatest reservoir of humanistic thought, study of these languages will continue to be widely required. If, as in the case with our ethical ideals, the average man in a busy world can secure the essence of this humanism by means of translations and interpretations, the classical languages will be primarily for the classical scholar, and not for those who merely aspire to a liberal education. The acid of the scientific method is being applied in education. In time it will destroy the baser metal, not alone in the teaching of the classics but in the teaching of science as well. In education, as in other fields, the day of passive acceptance of what is because it has been seems gone never to return. Here, as elsewhere, an appeal to the facts results in the undoing of traditional authority and establishes the authority of science. The changing classical requirements in modern education illustrate our point, although such changes are insignificant when compared with the possible revolution in education as a whole.

Recent changes in religious belief may be cited as a further example of the influence of scientific thought. By insensible degrees, theology has been losing its hold upon the western mind. The early Christian cosmogony has long been discarded by the educated laity, and is not taken seriously by many of the clergy. What the Copernican Theory did to the Heaven and Hell of an earlier period, the Higher Criticism, which consists of the method of science applied to the study of the Old and New Testaments, is doing in our own day to belief in a revealed religion. Facts! Facts! Facts that cannot be denied have everywhere rendered ancient beliefs untenable. Wonderfully interesting legends and fables the 
Bible stories now appear to be-records of attempted solutions of the mysteries of life. The science of comparative mythology is fascinating reading and is of even more than academic interest, because it explains the origin of many concepts which still exercise a profound influence upon the bulk of mankind. Because of scientific thinking, theology is being recognized as a barren form of speculation and is rapidly being separated from what may be termed religion. The latter maintains its hold upon men in terms of the human sympathy and ethical idealism essential in man's nature, without which social coöperation could not exist. Comparative study shows the various religions of mankind to have their foundations in these fundamental qualities of the human mind. The religion of the future will be scientific in that it will be all-comprehending.

In its sifting out of facts, science spares nothing, not even the most sacred of traditions, for science has its own sacred tradition of the open mind. One cannot view dispassionately the history of religious belief during the recent centuries without recognizing the changes which have occurred. And does any one believe that these changes will not endure or that others will not follow? Will not religion or what men will call religion in the future be at one with science, be, indeed, mainly a practical application of the ideas and achievements of science; and will not the scientific habit of mind satisfy the ethical and philosophical desires which have been hitherto formulated as religion and theology? The influence of science is manifest. Eventually, it will reconstruct the very foundations of religious thought.

Again, the scientific point of view appears in the changing philosophy of life. The old formulas, by which man long explained the riddles of existence, have failed in the light of scientific knowledge, even though they color much of our thinking. We may well consider the possibility of a life to come, but our immediate concern is with the life that is here and now. The ignoring of temporal affairs, emphasized so 
long as the thoughts of men were directed toward another world, has left an historical record in which we can take little pride. The humanistic philosophy of life, which flowered in Greece and which has blossomed again, is not the crude materialistic desire to eat, drink, and be merry. It is a spiritual joy in living and a confidence in the future, which makes this life a thing worthwhile. The otherworldliness of the Middle Ages does not satisfy the spiritual demands of modern times.

It was this humanistic ideal which strove for domination in the ancient world but at last went down defeated by that fear of the unknown which was man's heritage from savagery. The Greek ideal of life declined, despite the beginnings of scientific knowledge, because the bulk of mankind still beheld in nature a great unknowable filled with malignity toward men. Terror of the dark brought victory to that philosophy which made this world a vale of tribulation wherein man prepared himself for the next. From primitive times, blind fear swept on, unchecked save by the naked strength of the Greek mind. When Greece and Rome declined, fear chilled the hearts of men until in modern times, man mastered fear by scientific knowledge. To-day, men can face the unknown, strong in their conviction that mankind will ultimately comprehend much that has seemed unknowable. Nature now appears orderly, not capricious; causal, not magical. For those who come after us, if not for ourselves, the life that now $i s$ will possess greater possibilities than those ascribed in the past to a life beyond the grave. We have ceased to look upon nature with the dumb terror of the savage mind. We no longer grovel before her as an unknown power whose caprice may work us good or ill. Because of modern scientific knowledge, we look upon a world which is mainly, perhaps wholly, organized without reference to the desires of individual men, a universe of which we are a part and whose course we may hope to influence, if only to an infinitesimal degree. Our fate may be "on the knees of the 
gods," but the gods do not help us to that which we desire; we help ourselves, by understanding nature and by ordering our lives in conformity to her laws. Courage and high resolve are needed thus to face the realities of life. The night of fear is still about us, though we face the new day. At times, we lose all hope that a scientific philosophy of life can ever prevail within the hearts of men. In the faith that it will prevail, we lay hold upon scientific truth as we see it around us, believing that in the end no other state of mind will satisfy as well.

As a final illustration of the part played by science in this spiritual revolution which is the distinctive feature of modern times: The facts of biological science are profoundly modifying human thought. Their effects are seen in the present; and such facts have unbelievable possibilities for the future, because they deal with man's relation to his environment and with the nature of human personality. Biological science seeks to answer the question whence came man, and to explain what man is at the present time. It is also concerned with the whither of man upon this earth; it even dreams that research may some day solve the mystery of death. To-day, the philosopher recognizes the biological basis of philosophy, the theologian the biological development of theology, the historian the biological background of primitive historical events, and the man in the street the biological nature of his own existence. Indeed, biology occupies a pivotal position in human understanding.

But above all the applications of particular branches of science, man must apply the scientific method in the solution of social and of individual problems, lest civilization perish through its failure to progress. Biology in particular and science in general are fundamentally related to the welfare of mankind. Human life itself is the most absorbing of all scientific problems. If its riddles are ever to be solved it must be primarily through science and in the terms of science. 


\section{THE ORIGINS OF SCIENCE IN THE ANCIENT WORLD}

HAVING established the meaning and importance of science in general, the next step is to examine the historical origins of scientific thinking and knowledge, as a further introduction to biological science in particular. In such an inquiry, attention may be confined to the Near East, since isolation rendered India and China unimportant factors in the early intellectual development of the Mediterranean peoples. Commerce is known to have existed between Egypt and the Indian Peninsular at an early date. There were contacts between India and the primitive Mesopotamians. But the very early development of civilization in the Nile valley makes it probable that the tide of cultural influences flowed from west to east and not in the reverse direction.

\section{BEGINNINGS OF SCIENCE IN THE VALLEY OF THE NILE}

Beings capable of fashioning flint implements existed in western Europe as early as the Third Inter-Glacial Periodestimated as some 125,000 years before our era. ${ }^{1}$ Rock carvings and other remains indicate that cultural levels similar to, although not necessarily contemporaneous with, those reached by palæolithic races of Europe were also attained by implement makers who inhabited northern

1 Osborn, H. F., "Men of the Old Stone Age," p. 41. This estimate is a moderate one, as some other authorities place the appearance of the PreChellean flint workers even earlier than the Glacial Period. Buttel-Reepen, H. v., "Man and His Forerunners," p. 10. In the table given by J. C. Merriam, Sci. Monthly, p. 338, Apl., 1920, no time estimate appears, but the Palæolithic Period begins with the Second Glacial, and the Eolithic Period is extended well into the Tertiary. 
Africa during glacial times. The Sahara appears to have been a habitable region and to have possessed a temperate climate, at least during the earlier periods of European glaciation. With the close of the Ice-Age and the advent of the present climate, the southern shores of the Mediter-

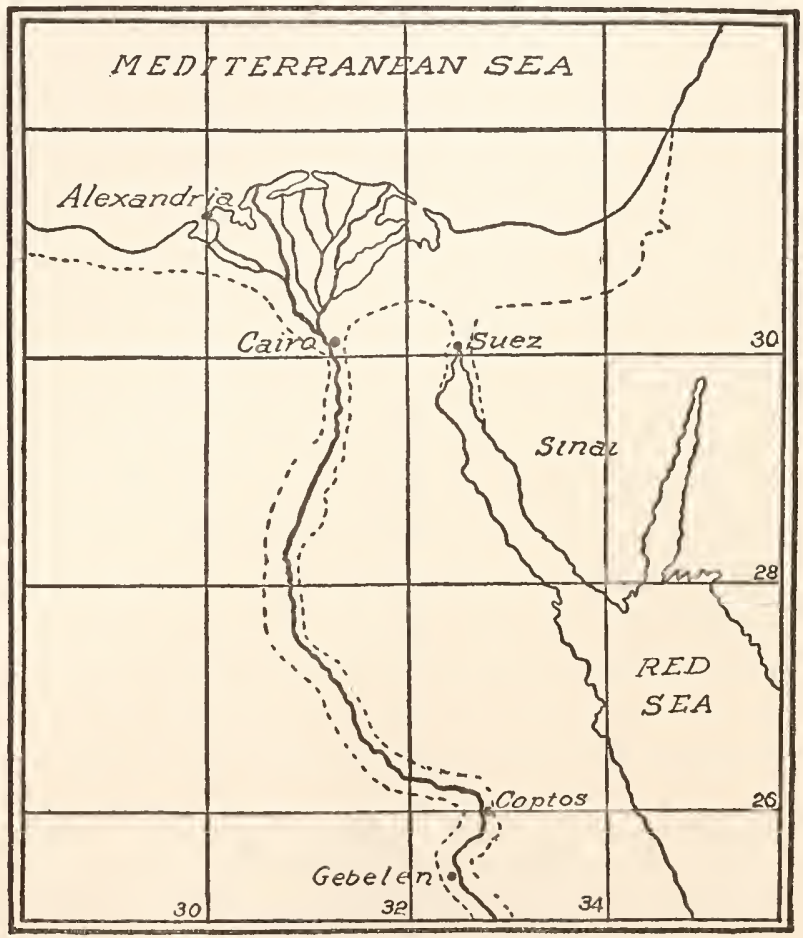

Fra. 1. Map of Egypt. Showing outline of the great fault-rift, which produced the Nile Valley, and of the former coast line. (Adapted from Blanckenhorn.)

ranean were populated by peoples whose cultural level was similar to that attained in southwestern Europe only in later times. It is not improbable that similar conditions had long prevailed and hence that a truly human culture emerged in northern Africa far earlier than in Europe. Egypt, in particular, exhibits not only the record of an indigenous civilization, but also evidences of antecedent neolithic and palæo- 
lithic cultures that extend to a very remote period in the past. ${ }^{2}$

The geological history of the Nile region ${ }^{3}$ has been such that we may determine the sequence of cultural remains in quite a definite fashion. Their actual age is, of course, subject to the limitations of all geological estimates of time. An exact time correlation with Europe is exceedingly difficult, if not impossible with our present data. Nevertheless, these remains are of great importance, because the completeness of the record is hardly duplicated in any other locality. The Nile valley originated, shortly before the European Glacial Age, in what is called a block or rift-fault. As shown by Figs. 2 and 3, a narrow section or fault-block (a $a^{\prime}$ ) of the Eocene limestone, extending from the former coastline near Cairo as far south as Coptos (Fig. 1), settled eight hundred or more feet below the general surface of the plateau. Lesser faults extended the valley southward a total distance of almost four hundred and fifty miles to Gebelen. The northern end of this rift, as shown by marine fossils, was for a time occupied by a fiord of the sea while to the south a fresh-water lake or chain of lakes existed for thousands of years. Later the fiord also became converted into a lake (Fig. 2). Eventually, this series of waterways became the River Nile, which in its early history carried a greater volume of water than at the present time.

Existence of the lake or lakes is evidenced by the extensive beds of lacustrine deposits which still appear along the valley walls (Fig. 3). The heavy rainfall of earlier times swept quantities of sand and gravel from the plateau. Many feet of this material were deposited in the lake upon the top of the fault-block (Fig. 2). After the river was established, its erosion cut the lake-beds almost to their bottom before the

${ }^{2}$ Breasted, J. H., "The Origins of Civilization," Sci. Monthly, Oct., 1919, pp. 304-8.

${ }^{3}$ Blanckenhorn, M., "Geschichte des Nil-Stroms," Zeitsch. der Gesell. für Erdkunde, 1902. 


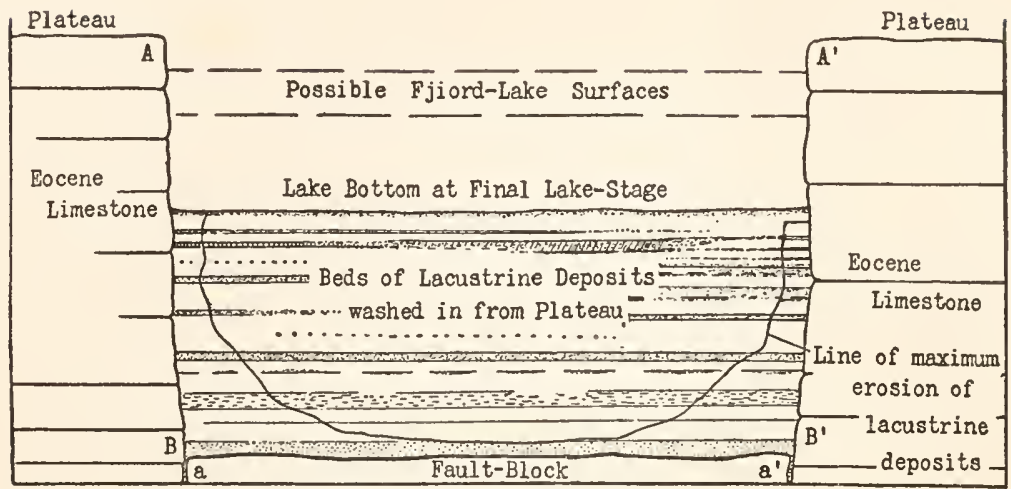

FIg. 2. Schematic Cross-Section of the Nile Valley, at a stage when the fiordlake had reached its maximum development. The lacustrine beds are shown filling a considerable portion of the rift produced by sinking of fault-block $a a^{\prime}$ from its original position $A A^{\prime} B B^{\prime}$. The downward displacement of the fault-block amounted to some 900 feet, as shown by the present height of the valley walls. The distance across the rift, as it now exists, varies from 4 to 15 miles. The extent to which the lacustrine deposits have since been eroded is indicated by the profile of the present valley which is outlined as in Fig. 3. The vertical dimension is greatly exaggerated. Compare with Fig. 3. (Adapted from Breasted and Blanckenhorn.)

dwindling stream became converted into the modern Nile and began to deposit the present alluvium. As shown by Fig. 3, the remains of the old lake-beds are exposed along the sides of the great rift. Below them are the remains of two so-called river terraces, marking stages during which the stream maintained its volume for a time sufficient to establish flood planes and lay down alluvial terraces that have since been washed down to rounded contours.

The peculiar features of the foregoing geological events enable us to trace the cultural record in a definite manner. The numbers on the right hand side of Fig. 3 indicate the location of the items which may now be enumerated in the order of their antiquity.

1. Many implements and flint workings, similar to palæolithic remains elsewhere in Northern Africa, are found scattered over the plateau. 


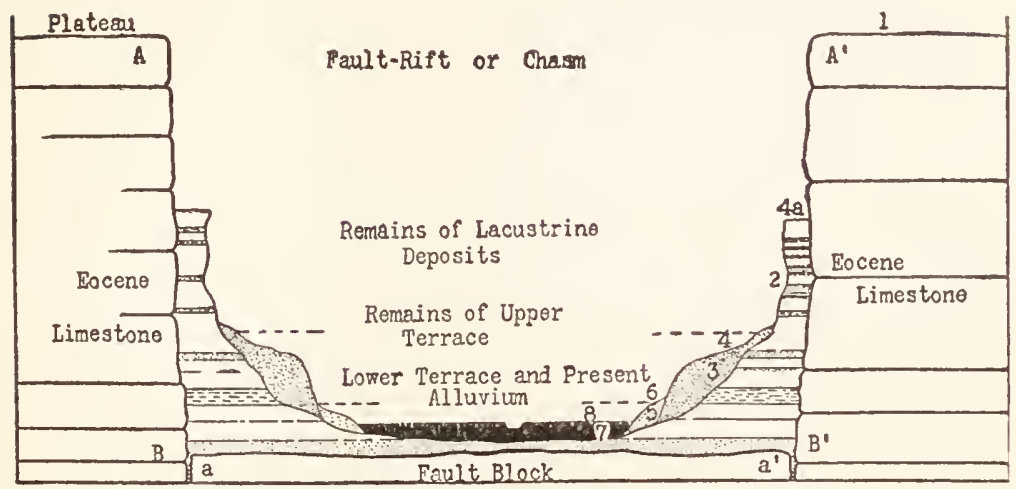

FIG. 3. Schematic Cross-Section of the Nile Valley at Present Day. Showing remains of lacustrine deposits and of two river terraces. The alluvium of the modern valley floor and the present Nile appear below. Vertical dimension is exaggerated. Compare with Fig. 2. Location of human artifacts is indicated by figures on the right hand side as explained in text. (Adapted from Breasted and Blanckenhorn.)

2. Implements similar to (1), but found embedded at various levels in the lake deposits, are believed to have been washed in from the plateau, since this was the source of the material composing the lake deposits. Hence some at least of the plateau implements antedate the formation of the lake deposits.

3. Many implements are found embedded within the upper river terrace. These are similar to (1) and (2). The material of this terrace was derived by washings from the older lake deposits or from the plateau.

4. Implements on any undisturbed surface of this terrace are of later origin than (3).

4a. Prehistoric cliff pictures of game animals, primitive boats, and the like, now found upon the upper cliffs are believed to be contemporaneous with (4).

5. Implements within the lower terrace would be regarded as more recent than (4), or as washed down from the earlier formations above, since the material of this terrace had such an origin.

6. Implements upon any undisturbed surface of this lower terrace would be later than (5).

7. Implements, fragments of pottery, etc., have been found deeply embedded in the present alluvial plain. The transition 
from a palceolithic culture to a dawning civilization would be looked for in these deposits, reading from the bottom upward.

8. The archæological and early historic record of Ancient Egypt is found upon the surface and within the upper layers of the alluvium.

Assuming that the foregoing geological interpretations are correct, the record is tolerably complete from the times when flint-working beings inhabited the plateau and lived along the precipitous shores of the fiord and lakes, through the diminishing stages of the river to the period in which a primitive civilization made its appearance among the dwellers of the modern valley. If the lacustrine deposits are correctly placed in the late Pliocene and First Glacial periods and if the presence of flint artifacts within these lake deposits and upon the plateau has been correctly interpreted, beings capable of producing rough stone implements existed in Egypt even as early as the First Glacial Period of Europe, which may be conservatively estimated as some 500,000 years from the present time. Only the most extreme placing of the earliest European flint workers (Pre-Chellean) would take us so far into the past. ${ }^{4}$

Perhaps the age of the lake deposits, by which the age of the plateau implements is determined, has been overestimated. The interpretation of the lacustrine flints as washed in from the plateau may be incorrect. But in any case it appears that implement-making beings existed in northeastern Africa at a very remote period. It is generally accepted that the Pre-Chellean flint workers entered Europe from another continent. The region of southeastern Asia has been most commonly looked to as their point of origin. In view of the geological and cultural records of the Nile valley we may well entertain the hypothesis that the immediate migration into Europe may have been from Africa.

${ }^{4}$ The vexed question of the so-called eoliths is disregarded, since the flints of the lake-beds and the plateau are comparable with the Chellean and PreChellean implements of western Europe. 
Further search for palæolithic remains in northern Africa and correlation with those of western Europe seems highly desirable.

Whatever the period of the beings who produced the flints now found upon the plateau and within the lake deposits, the implement record within the valley itself is complete, beginning with the oldest river terraces. The earliest known archæological remains are comparatively recent, appearing within the present valley floor, and are estimated as belonging to a period about 15,000 в. с. ${ }^{5}$ They have been obtained by borings in the alluvium and consist of fragments of pottery. Elsewhere, pottery is characteristic of an early neolithic stage of development. Between 15,000 в. с. and 5000 в. с., the inhabitants of the Nile valley advanced through a neolithic culture to a primitive civilization. The earliest known burials are placed at approximately 4000 B. c. and show, in addition to pottery and flint implements of remarkable perfection, hand-bored vessels of stone, implements and ornaments of ivory, and occasional articles of copper. Barley, millet, wheat, and flax were under cultivation, as shown by the contents of the pottery jars found in the graves. Some of the bodies are wrapped in linen which exhibits considerable textile skill. Sheep, goats, long-horned cattle, and donkeys are pictured as domesticated animals. It is a fair presumption that the domestication of the animal and plant life here represented consumed many centuries. The development of pottery-making as early as 15,000 B. C. take us still further into the past. We see stretching back of the dawning age of metal, as shown by the burials (4000 в. с.), a period of life on the alluvium, beginning perhaps as early as 20,000 years before our era. Future investigations will probably make the record complete, both palæontologically and archæologically, from the original occupation of the valley by the flint workers of the plateau, perhaps 200,000 years or more ago, to the earliest fixed date ${ }^{5}$ Breasted, J. H., loc. cit. 
in history (4241 в. c.), as established by the Egyptian calendar with its year of twelve months and three hundred and sixty-five days.

What is known concerning earliest civilized Egypt, therefore, pictures a society in which the rudiments of the practi-

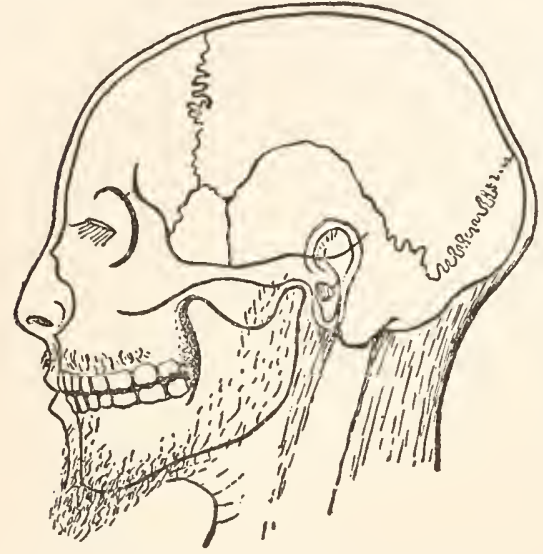

FIG. 4. Profile of a Pre-historic Egyptian. Restored by Elliot Smith from an early pre-dynastic skull. (Redrawn from Breasted.) cal sciences were well established not later than 4500 B. C. If it is true that Egyptian civilization antedates that of Mesopotamia, the latter, although of independent origin, probably received from Egypt more than it gave. Most authorities maintain that civilization had its earliest beginnings in Egypt. It may have arisen independently in Mesopotamia and in the Far East at a later date. But with our present data we must look to the Nile valley for the earliest known transition from palæolithic and neolithic men to those whose accomplishments mark the earliest beginnings of extensive scientific knowledge. There seems to exist in northern Africa, a continuity through the palæolithic savagery and the neolithic barbarism of the Ice-Age, to a cultural level which was the forerunner of the Greco-Roman, and hence of our own western civilization.

It appears that Egyptian craftmanship was of the greatest significance to the Greeks, who received their earliest models largely from this source. The civilization of Greece, which was the first emergence of a strictly European people from barbarism, now appears to have been initiated by contact with the Egyptian and Mesopotamian cultures through the 
Phœnicians. The Ageans, whom the Greeks conquered, were highly civilized, but their culture seems to have been obliterated rather than absorbed. The Greek alphabet arose through imitation of the Phœnician, mathematical concepts were received from Mesopotamia, Greek architec-

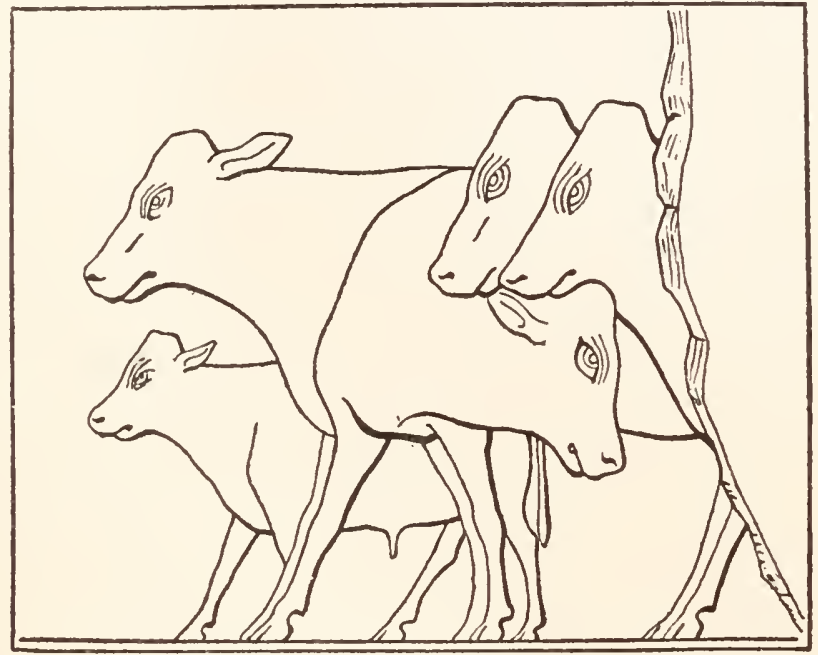

Fic. 5. Hornless Breed of Egyptian Cattle. From a tomb relief at Gizeh, 29th century B. C. (Redrawn from Breasted.)

ture, as shown by the derivation of the colonnaded Greek temple and many lesser features, had its prototypes in Egypt. In like manner, many of the earliest intellectual and mechanical accomplishments of the Hellenic race are traceable to what existed in the civilizations previously established at the eastern end of the Mediterranean.

The scientific achievements of the Egyptians during the thirty-five centuries preceding 1000 в. с. may now be summarized, without too great emphasis upon the exact dates, since it is our purpose merely to indicate the total legacy of natural knowledge which passed from Egypt to Europe by way of Greece. Extensive archæological records appear after 4500 в. с. A steady though slow development may be 
noted during the millenium which follows. Fire, implements, and finally domesticated animals and plants had been the great achievements of the human race during the ages of stone. Metals, writing, and government were the more important achievements in the early advance of the Egyptians toward civilization. The extensive domestication and

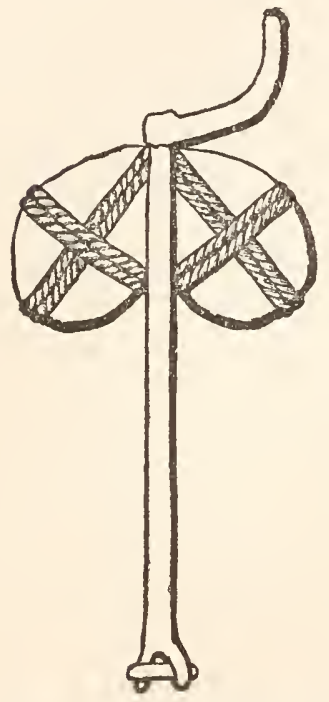

Fig. 6. The Earliest Known Machine. An Egyptian crank drill, about 3400 to 3000 B. C. (Redrawn from a figure by Borchardt in Breasted.) specialization of a wide range of animal and plant life are examples of a practical knowledge which was the beginning of biological science. In medicine, the Egyptians excelled all other ancient peoples. Only the study and treatment of mental diseases seem to have been neglected. The earliest known machine is an Egyptian crankdrill invented before 3000 в. c. (Fig. 6). The potter's wheel was of similar early origin. The ox-drawn plow arose as a modification of the peasant's hoe.

For a long time the advance was gradual. But with the opening of the Pyramid Age (3000-2500 B. c.) there appears a single century, which, alone of all the centuries, is comparable to our nineteenth century in its mechanical achievement. In 3050 B. c., the first stone masonry had not been laid. Less than one hundred and fifty years later the great pyramid of Gizeh was under construction. The transition from barbarism thus culminated suddenly in this "Wonderful Century" of the ancient world. The pyramids and other architectural productions of the Egyptians are important as indications of the perfection of their mechanical skill. A marvelous manual dexterity is exhibited, alike by their sculpture, their architecture, and their craftsmanship. The earliest sea-going ships appear in the 30th century B. C. 
The laying out of buildings and the construction of irrigation ditches are examples of engineering feats which excite admiration. Perhaps the most remarkable of all is the recording of the levels of the Nile in all latitudes, which resulted in a line being carried in one plane around all the bends of the river for some seven hundred miles. Although in the same plane throughout its length, this line is not exactly parallel to the flood slope for the entire distance. But when it was later extended some two hundred miles up the river the plane and the flood slope became more closely parallel. ${ }^{6}$

If, as some maintain, there exists a correlation between climatic conditions and the character of a civilization, a parallel may be drawn in ancient Egypt. The climate of the Nile valley offered an appropriate setting for a civilization which was intensely material, but at the same time peaceful and benign. But the Egyptian, despite his practical accomplishment, exhibits certain mental crudities. ${ }^{7}$ In abstract thinking, there seems to have been much confusion of thought. There is no clear evidence of a conspicuous ability to generalize, and with this may perhaps be correlated a certain planlessness in architecture and an inaccuracy of artistic representation. If these were characteristics of Egyptian thought, we can the better understand their scientific limitations. Wonderful in their grasp of mechanical processes, in the confidence with which they undertook great enterprises like the building of the pyramids, and in their governmental organization, they give no evidence of the transcendent imagination which led the Greek in his quest for natural causation. No other people in history ever persisted for so long a period without external invasion or serious internal revolution. Their material foundation was early assured. Yet the Egyptians seem never to have passed beyond the more immediate problems of science and philosophy. It is this failure to progress which constitutes

${ }^{6}$ Breasted, J. H., loc. cit.

7 Taylor, H. O., "Ancient Ideals," p. 12. 
the strongest suggestion of their mental limitations. We cannot ascribe to them, as to certain of the Greeks, the intellectual qualities of the modern scientific mind. Nevertheless, the classical tradition of the debt to Greco-Roman culture should not conceal the fact that many of the mechanical and artistic elements of western civilization originated in the valley of the Nile, and were merely passed over to western Europe by the Greco-Roman world.

\section{DEVELOPMENT OF SCIENCE AMONG THE PEOPLES OF MESOPOTAMIA}

The climatic and racial background of ancient Mesopotamian culture is in marked contrast with that of Egypt. In the Nile valley we see a homogeneous people, apparently of a stock similar to the Mediterranean race of a later period, living in a land well protected by natural barriers and with agricultural conditions of great stability. The Mesopotamian plain was, by contrast, the meeting place of conflicting races from the desert to the south and west and from the mountains to the north. From the period of the Sumerian peoples, whose documentary record begins about 3000 B. c., we find a recurring struggle between established civilizations and barbarian invaders. Moreover, agricultural conditions were less stable than in Egypt.

The absence of an abundant supply of stone led to the use of brick for most building purposes. Hence the record is less extensive in certain lines. The sun-dried bricks have crumbled to ruins, but the records upon the baked cylinders and tablets have proved almost indestructible and whole libraries have been preserved. In the main, the civilization thus depicted appears to have originated independently in Mesopotamia, despite extensive trade, and consequently exchange of ideas, with Egypt after 2500 B. c. That one item, at least, was actually derived from Egypt is indicated by the fact that split-wheat was called by its Egyptian name. 
Many elementary facts of mathematical and physical science were established as early as the third millennium B. C. In Babylon, we find standard measures of length, weight, and capacity issued by governmental authority. Our own unit of weight, the pound, has descended from the Sumerian mina. Our time unit sixty had a similar origin. The earliest writing which was exclusively alphabetic was that of the Aramean Syrians, in contact with Mesopotamia to the north and west. The multiplication table, tables of squares and cubes, a duodecimal and a decimal system appear in the sculptured records, bearing testimony to the intelligence which made so admirable a beginning in the basic sciences. ${ }^{8}$ The elements of geometry arose, apparently in connection with the measurement of land. A calendar was developed to meet the demands of Agriculture. Among the items of modern life, illustrative of applied science and independently originated by the Mesopotamians or through them transmitted to Europe, may be enumerated: the wheel, as a burden-bearing device (3000 B. C.); cotton, derived from India at an early date; the domestic horse, coming to Babylonia from the north about 2100 B. C.; and iron, which was first extensively used by the armies of Assyria. The beginnings of a postal system under Sennacherib (700 в. с.) may also be mentioned. ${ }^{9}$

The record of the Chaldean civilizations, as drawn from the inscriptions on temple and palace walls and on the cylinders and tablets of clay, is tolerably complete. It tells us of civilizations in which astronomy, mensuration,

${ }^{8}$ The original discovery of what might be called the properties of the various numbers must have been a wonderful experience for the human mind. It is not surprising that merit and demerit were ascribed to numbers which behaved so differently in computation. For an interesting discussion along this line see: Slocum, S. E., "The Romantic Aspect of Numbers," Scientific Monthly, July, 1918.

9 Whetham, W. C. D., and C. D., "Science and the Human Mind." Draper, J. W., "History of the Conflict between Religion and Science." Sedgwick, W. T., and Tyler, H. W., "A Short History of Science." 
arithmetic, agriculture, and the calendar were recognized as worthy the attention of priest and administrator. Thus the first astronomer's were probably the Chaldean astrologerpriests, whose vigils in the clear atmosphere of an arid region led them to watch the stars and to recognize order and law in the heavens. Astrology was their dominant motive. But astronomical events were carefully observed and are recorded in the inscriptions as early as 2000 B. C. Subsequently, these early astronomers were able to predict the eclipses of the moon. Our present names for the signs of the zodiac-the Crab, the Scorpion, and the like-are lineal descendants of the Chaldean astronomy, in which the sky was mapped and the names of animals, symbolic of gods, given to the several divisions. Intermingled with religious beliefs, this modicum of knowledge became a system by which it was claimed that future events and the fates of men could be foretold. The sorcery and magic of Chaldea, along with its astrology, spread westward, exerting its influence, first upon Greek and Roman thought, and later upon that of western Europe. Thus, the idea of the virtues inherent in certain numbers, so potent throughout the Middle Ages, appears to have originated in Mesopotamia and even to-day fortune tellers claim for their art descent from the soothsayers of Chaldea and Babylonia.

Speculative science and rational philosophy might have arisen from the practical scientific knowledge which thus came into being. That such was not the case is perhaps explained by the fact that the gods of the Mesopotamian peoples were regarded as hostile and ever in need of propitiation. Fate hung heavy on the human mind and men's thoughts were always seeking to avert its decrees. "Strange mingled streams of foolishness and knowledge" arose in Mesopotamia and flowed west, north, and perhaps east. ${ }^{10}$ Religious beliefs were hopelessly intermingled with scientific and philosophical thought. The Hebrew story of the ${ }^{10}$ Taylor, H. O., loc. cit., p. 13, Vol. I. 
Temptation of Eve, which was of Babylonian origin, and in which the acquirement of knowledge was a form of sacrilege, is an echo of a conception of the universe unfavorable to the development of scientific thinking. The tumultuous existence of these peoples of Mesopotamia throughout many centuries, during which one conqueror followed another, may have emphasized the concept of unfriendly gods, while the peace of Egypt may have been largely responsible for gods who smiled on men. ${ }^{11}$ The practical scientific achievements of these Near-Eastern peoples, before the advent of any European civilization, constitute the first great advance of science. If there remained for the Greeks the first important advance toward a theoretical explanation of the universe, the material accomplishments of the Near East should not be disregarded. The orientalist has done an inestimable service in showing the foundations upon which the first strictly European civilization was reared.

CONTRIBUTION OF GREECE TO THE ADVANCE

OF SCIENCE

In Greece, the seeds of scientific thought, which had germinated among the earlier peoples of the Eastern Mediterranean, reached their full fruition in the ancient world. We have been taught to regard the rise of Hellenic civilization as a social and intellectual phenomenon unparalleled in history. How Greece so suddenly came to her glory was long a mystery. But the archrological investigations of recent years have established certain facts of continuity, previously unknown. Investigations in Crete have shown the existence of the so-called Minoan civilization, originating from an indigenous neolithic foundation, which can be followed in the lower strata of the hill of Cnossus, back to a period perhaps as early as 7000 B. C. This neolithic culture artic-

${ }^{11}$ Jastrow, J., "Aspects of Religious Belief and Practice in Babylonia and Assyria." 
ulates on the one hand with the late palæolithic of western Europe and northern Africa and on the other is transformed into the early Minoan about 3400 B. C. Subsequently, the Minoan civilization was in intimate contact, first with Egypt, and later, with Mesopotamia, although never wholly dominated by either. ${ }^{12}$

The indigenous origin in Crete of this Agean culture is of prime importance. Egypt, Mesopotamia, and Crete, although interacting at a subsequent period, appear to be three separate lines of evolution connecting the barbarism of the Late Stone Age with the civilization of later Europe. The first towns upon the European continent were the settlements of the Ageans at Mycenæ, Tiryns and elsewhere upon the mainland of Greece. The cultural level established upon the shores of the Egean Sea constitutes a third great civilization of independent origin in the near-eastern world. After 2500 B. c., the contact of the Egeans with Egypt was increasingly intimate. Crete became a dependency of Egypt following the development of Egyptian naval power. Cretan envoys bringing tribute are recorded during the fifteenth century B. c. By the beginning of the second millennium the Egeans upon the island of Crete were highly civilized, their "Grand Age" being the sixteenth century B. C. Later, this high civilization spread to the mainland of Greece. These facts are important in determining the period of the actual dominance of the Greeks in the Egean region, which began about the twelfth century before our era. ${ }^{13}$

${ }^{12}$ Evans, Sir Arthur, "New Archæological Lights on the Origins of Civilization in Europe." Address of the President of the British Association for the Advancement of Science, 1916. Reprinted in Science, Sept. 22, 1916. See also: Baikie, J., "The Sea Kings of Crete"; and Hawes, C. H., and H. B., "Crete the Forerunner of Greece."

${ }^{13}$ One of the most specific intimations of the ejection of the Egeans, by the incoming Greeks, is found in the record of a naval battle pictured on the wall of a temple at Thebes. The conflict, which took place off the coast of Syria, was between Cretan fugitives and Egyptians. Breasted, J. H., Scientific Monthly, Feb., 1920, p. 206. 
Thus, some two thousand years before our era there existed upon the shores and islands of the Egean Sea a civilization which had already attained a high level. The ethnic stock of these Egean folk was the long-headed, dark complexioned, delicately molded Mediterranean race made familiar through studies upon European anthropology. During the early centuries of this second millennium there came from the north, by way of the Black Sea and the Balkans, a flood of barbarians. It is clear from the references to their stature, their blue eyes, and their tawny hair, as well as from their cultural traditions and the anatomical evidence derived from skeletal remains, that this invading people was of the Northern European or Nordic stock. Their use of the funeral pyre, as described in Homer, is one custom among many which differentiates them sharply from the Egeans. The Homeric tales are, presumably, founded upon certain of their early exploits, just as the fabuluous stories of King Arthur have some sort of an historical foundation. The original Hellenes were perhaps in possession of the mainland for centuries, before they learned to build ships and voyage to the islands. The period of their original invasion is uncertain, since they possessed no written language until a much later period. But their occupation of the Peloponnesus can be placed in the eleventh century B. c.

Following the Hellenic conquests, the Ægeans in Crete and on the mainland survived in large part as a subject population. In the course of centuries, the stock of the original invaders, and others who doubtless followed them, must have become somewhat intermingled with that of the conquered Egeans. The Greek population some four or five centuries later, at the dawn of its written history, was thus of double origin. The extent to which the two elements had then fused together is, of course, impossible to ascertain. ${ }^{14}$ It is fair to surmise that for many centuries a land-

${ }_{14}$ The fact that the Philistines of Biblical times are known to have originated from a group of Cretans, who fled before their conquerors, shows that 
holding aristocracy of Nordic origin was superimposed upon a larger group of dependents which was almost wholly Ægean. For example, in Sparta and Crete the citizens were virtually military garrisons commanding a hostile population. The helots or serfs were controlled with difficulty. Gradually the conquering stock died out or mingled with the conquered as the two intermarried and the more competent Egean strains came to the fore. It is not clear to what extent the Nordic element existed throughout Greece at a later date, but there is evidence that the Egean strain was more extensive among the Athenians than in many other communities. We know that there was present everywhere a relatively large population of slaves. The modern student of racial heredity finds even these meager facts of interest as a clue to the Hellenic genius. Some critics have believed that there exists a causal connection between the dilution of the northern blood and the final decline of the Greek states. The attainments of the Ageans before the advent of the invading Hellenes renders such a belief less plausible.

Continuity between the culture of Hellas and the three preceding civilizations of Egypt, Mesopotamia, and Crete has thus been established. It does not appear that the northern conquerors brought to their new home a culture which nearly approached that of the Egeans. Civilization was, for the time being, obliterated and barbarism prevailed. The original invaders were still in a neolithic stage. They did not bring civilization with them, but only strong bodies, and minds capable of assimilating some measure of the culture they trampled upon. The Agean civilization was crushed, but some influence must have remained. In the course of time there was increasing contact, through the Phœnician traders, with Egypt and Mesopotamia. Greek civilization was, therefore, not a spontaneous product, as there was a certain amount of forced emigration eastward and southward. But the majority of the Egeans no doubt remained as serfs and slaves. 
was long supposed to be the case. Its most unique feature was the receptivity of the primitive Hellene to the legacy of the ancient East and his capacity to make this legacy his own. ${ }^{15}$

The distinctive accomplishments of the three antecedent civilizations had been practical and materialistic. Despite their diversified attainments, the analytical quality appears to have been lacking in both Egypt and Mesopotamia. Of the Minoan culture we know little in this regard, because the inscriptions are, as yet, mainly undecipherable. The importance of the Hellenic culture in relation to science lies in its philosophical analysis of natural phenomena, including those of human social organization. Explanation of the physical universe, which is now the function of natural science, was first seriously attempted by the Greek philosophers. Their intellectual superiority lay in their ability to generalize and to abstract. Hard thinking and close reasoning were distinctive traits. These appear in their art, their literature, their philosophy and their science. They generalized and grasped the principles that lie behind the products of human eyes and hands. They showed an ability to separate meaning from existence. Nothing approaching their capacity for abstraction appears in the records of antecedent civilizations, unless the monotheism of the Hebrews can be taken as an example of a similar capacity within the ethical field. In any history of science, the Greek is of overshadowing importance because of his scientific turn of mind. ${ }^{16}$

${ }_{15}$ We seem to see a race suddenly coming to its own- "False, boastful and licentious perhaps, but with a sense of beauty, a confident joy in life, a warmth of affection that bespeak a gallant, vigorous, open-minded, conquering people, a people of extraordinarily brilliant original intellectual endowment, tempered and purified by the rigors of the North, and then placed in a land of glorious beauty, where the wine-dark sea brought the trade and knowledge of the world to their doors, where the climate smiled upon their fortified homesteads, where abundant slaves made life easy, and gave leisure for the growth of the highest forms of philosophy, literature and art." Whetham, loc. cit., p. 33.

${ }^{16}$ Mahaffy, J. P., "What Have the Greeks Done for Modern Civilization?", Chap. VIII. 
The origin of democratic institutions in Greece is no doubt to be correlated with the type of mind above described. The Oriental had acquiesced in a subjection of mind and body to political and religious tradition. Democracy in any sense was unknown. Corporate and class spirit was characteristic of ancient oriental society. The Greeks developed the idea of the individual and his intellectual worth and so gave scope to genius. They enthroned the citizen above the king, as well as natural law above the gods. The wonder is not that in the end they failed to conquer the world but that they wrought so well. Man rather than nature was, however, their culminating concern. "Know thyself" is a phrase significant as a clue to an underlying philosophy. In this respect our present age may well profit by the Greek spirit, which at its best was too well balanced to subordinate human aspiration to the materialities of existence.

We are more particularly concerned with the place of science among this many-sided race. But this cannot be discussed aside from their philosophy and their religion. In the religion of Greece is seen reflected the Greek mind with its joy in living. In the main, the gods smiled on men and stood ready to help them. There was no established church or priesthood, tending towards the crystallization of current doctrines into dogmatic beliefs. As time went on, the idea of a single God, the supreme and righteous Zeus, was developed among the more advanced thinkers. As with the Hebrews, this conception arose by gradual stages, finding its culmination in Plato's reconstruction of religion and in the mysticism that was taken over from Platonic thought by the early Christian theologians. In general, Hellenic monotheism was intellectual rather than ethical. It, therefore, tended to supply the deficiencies in the Hebrew system when the latter was taken over by Christianity. ${ }^{17}$

Philosophy, distinct from religion in name as well as in

${ }^{17}$ Dickinson, G. Lowes, "The Greek View of Life." Also: Farnell, L. R., "The Higher Aspects of Greek Religion." 
spirit, is here first recognizable. Inquiry did not stop with everyday experience, but leaped beyond to theories of the universe and of ultimate reality. "All things have arisen from water and will return to water," not water but "air or fire or the four original elements or atoms are the universal principles of reality," are examples of Greek speculative thought. The intellectual failure of the Greek was his inability to see the point at which philosophic speculation so far outruns fact as to become unprofitable. That his speculations on the evolution of life and on the atomic nature of matter are in line with the facts established by modern science is not mere coincidence. It is rather the insight of master minds groping towards the truth without sufficient factual knowledge. The Greek in his theorizing had the advantage of a rationalistic point of departure, since the Greek religion offered no compelling philosophical system as did Christianity at a later day. Deductive logic was formally organized, while the inductive method was practiced, if not clearly apprehended. ${ }^{18}$ The concept of physical causation was apprehended. Thus the Greek perceived the general in the midst of the particular more truly than did any other ancient people. Moreover, the part played by intellect was for the first time, consciously recognized.

It is unsafe to generalize regarding racial traits even among our contemporaries. But the capacity of certain of the Greeks for abstract and analytical thinking marks them as the intellectual forebears of modern scientific thought. The Greek mind showed its ability to grasp the scientific

18 The following example of the inductive method is cited by Sedgwick and Tyler, "A Short History of Science," p. 54: "We may recognize here the characteristic elements of the inductive method, first, observation of the particular fact that in a certain right triangle, with sides, 3,4 , and 5 , the sum of the squares on the two sides is equal to that on the hypotenuse; second, the formation of the hypothesis that this may be true also for right triangles in general; third, the verification of the hypothesis in other particular cases. Then follows the deductive confirmation of the hypothesis as a law for all right triangles." 
spirit of truth by the work of Hippocrates and his school (c. 400 в. с.) in medicine, by that of Archimedes (287-212 B. c.) in mechanics, and of Aristarchus (c. 270 B. C.) in his heliocentric theory of the universe. ${ }^{19}$ But everywhere speculation outran ascertained fact. Although Greek philosophy permeated the theology of Christendom for many centuries, and although the science of Hippocrates, of Archimedes, and of Aristarchus, and the great Aristotelian tradition flowed into Europe through Rome and Constantinople, only to be fully acknowledged as Greek in origin in the period of the Renaissance, the birthplace of modern science was not Greece but western Europe. In Hellenic thought, science was as a rising tide, while philosophy was at the flood. Among the causes for the decline of Greek civilization may have been the failure to appreciate the solid ground of scientific fact upon which has been founded the material and spiritual progress of modern times.

The Greek did not sufficiently acknowledge science, with its demand for sure even though slow progress, as distinct from the speculations of philosophy. Nor can one consider the science of Greece apart from its philosophy, since the Greeks were philosophical scientists to a degree which even philosophers have not surpassed in later days. Of all the speculations, non-scientific at the time but since brought within the realm of science, those concerning the nature of matter and the origin of life are of most interest at the present day. The very existence of such speculations indicates a remarkable advance in thought. When indulging in them, these philosopher-scientists were reflecting upon and offering hypotheses for problems which twenty centuries later became subject matter for exact science. Empedocles separated energy from matter, and Democritus developed a

${ }^{19}$ Libby, Walter, "An Introduction to the History of Science." Also: Sedgwick, W. T., and Tyler, H. W., "A Short History of Science"; and Browne, C. A., "Four Anniversaries in the History of Greek Philosophy," The Open Court, Dec., 1915. 
theory of all matter as composed of atoms-theories which failed to establish themselves because they lacked observational and experimental support. But what a contrast to the mental attitude of earlier peoples and to that of early Christendom is here presented!

Speculations concerning the origin of life proceeded along two lines-the origin of the individual and the origin of the race. These two problems, which have so concerned the biologist of modern times, were not always clearly separated. They have, of course, certain features in common. The speculations of the earlier Greek philosophers culminated in the doctrine of Aristotle that living things originated from germs, composed of soft masses of matter, or, in the case of higher forms, sprang directly from the earth. We find here the beginnings of the controversy over spontaneous generation, which was not settled until the third quarter of the nineteenth century. The explanation of racial originswhat we now term evolution-was developed among the Greeks as an outgrowth of their observation that nature was in a state of constant change. Seeing the apparent flux of all material things, the Greek philosopher speculated, not only upon the existence of a permanent element in nature, but also upon the nature of the change that was forever in progress. Thus arose the idea of living things as changing; and, finally, the concept of a succession of animal types, and of descent with modification, was vaguely expressed. Again, the concept of a survival of the fittest was dimly recognized by Empedocles; and Aristotle clearly stated the problem, if not the solution, of the phenomenon of adaptation in organic nature. As a result of these speculations, the Greeks, as one writer expresses it, "left the later world face to face with the problem of Causation in three forms: first, whether Intelligent Design is constantly operating in Nature; second, whether Nature is under the operation of natural causes originally implanted by Intelligent Design; and third, whether Nature is under the operation of natural causes due 
from the beginning to the laws of chance, and containing no evidences of design, even in their origin." 20

Aristotle, the greatest of all the Greek philosopherscientists, is especially interesting to the biologist, because he has been called the father of zoölogical science. Taken as a whole, his work represents the culmination of the scientific genius of the Hellenic race. He was the first individual of whom it is recorded that he took notes and collected books, with a view to an encyclopadic organization of existing knowledge; he was also the first to definitely formulate the principles of deductive logic. He was the greatest systematizer of knowledge that the ancient world produced, and was in general the founder of most of the sciences which originated in the ancient world. This in part accounts for the fact that his works were looked upon as authoritative in science and philosophy until modern times. It is no wonder that Dante designated him as "the master of them that know." But more than this, Aristotle possessed the mind of scientific genius.

Aristotelian philosophy, in opposition to the supernaturalism of Plato, was the philosophy of the concrete and particular substance or thing; and was, despite its coloring of Platonic supernaturalism, the logical antecedent of modern scientific realism. In his scientific conclusions, Aristotle was influenced by his philosophical preconceptions, but the fact that his dominant philosophy was realistic rendered this influence of less significance. In biological science, he seems to have been familiar with a large number of animals by actual dissection, and to have possessed a factual knowledge greater than any student of animal life until the period of the Renaissance. He illustrates the Hellenic genius, on its intellectual side, more completely than any one individual. His works, in garbled and fragmentary form, constitute the greatest single item in the philosophical and scientific legacy inherited from the ancient world. In him was epitomized 20 Osborn, H. F., "From the Greeks to Darwin," p. 68. 
the genius for generalization so characteristic of the Greek mind.

But the attainments of the Hellenic mind can be illustrated by institutions as well as by individuals. The conspicuous example, in science, is the Museum at Alexandria. Here, the Macedonian rulers brought together the literature of the ancient world in a great library and, by attracting scholars from the entire Mediterranean region, created what more nearly approaches the great university of the present day than any other institution of ancient times. The $\mathrm{Mu}$ seum was the institutional culmination of the intellectual genius of the Greeks as Aristotle was the personal. Stimulated no doubt by the older eivilizations with which the conquests of Alexander had made them familiar, the Greeks in this cosmopolitan city of the Ptolemies assumed the intellectual leadership of the ancient world. Founded about 300 в. с., the Museum continued in existence for some 700 years. The three-fold object of this ancient university was the perpetuation, increase, and diffusion of knowledge. We shall comment only upon its encouragement of natural science.

Fortunately, the Aristotelian doctrine of factual knowledge and inductive reasoning were dominant at the outset. To observation, there was added an increasing amount of experimentation. We find here the beginnings of the method which has yielded such important results at the hands of the physical scientist during the Modern Period. Archimedes and Ptolemy were the intellectual forebears of Galileo and Copernicus. Here Ctesibius and Hero invented the fire engine; and the first steam engine was produced. In geographical science, the technique of map making and surveying were examined, and the circumnavigation of Africa was proposed. The globular nature of the earth was accepted, and attempts were made to determine its circumference. In the field of geological science, the submergence and the elevation of land masses, and such problems as the origin 
of a strait, like that of Gibraltar or the Dardanelles, were considered in terms of the rationalistic explanations of the present day. The attempts to discover an elixir of life were a foreshadowing of the work of the later alchemists from which our modern chemistry arose. Biological science was not neglected, for the medical traditions of Hippocrates were known in Alexandria and there mingled with those of ancient Egypt. The examination of the human body was permitted, and the dissecting room of the Museum was the earliest anatomical laboratory. The existence of zoölogical and botanical gardens is also recorded.

For the purposes of this discussion, these particular items are of interest, but it is of more importance that the Alexandrian Museum represents the earliest institutional attempt at the systematic organization and extension of scientific knowledge. Moreover, the science of Alexandria did not restrict itself to observation, but relied also upon experiment. Although the great days were gone centuries before the Mohammedan conquest, it is not without significance that the Arabs became proficient in the same fields of knowledge which had been highly developed in Alexandria at an earlier period. ${ }^{21}$

In the hands of a race politically and morally dominant, these material and spiritual attainments of the ancient Greeks might have conquered the world. But in Alexandria, even before the Roman conquest, the government was insecure. Dissipation was rife; and the paralysis born of moral skepticism had become almost universal among the upper classes with the decay of paganism. In the technical operations of science, there were certain limitations that were not removed until long after the period in question. For example, physical science was handicapped by the lack of

${ }^{21}$ Draper, J. W., "History of the Intellectual Development of Europe." An excellent account of the Alexandrian Museum will be found in Chapter VI. See also: Browne, C. A., loc. cit.; and Mahaffy, J. P., "The Progress of Hellenism in Alexander's Empire." 
accurate and convenient instruments for the recording of both time and of temperature. Another deficiency was in the means and method of arithmetical computation. We can appreciate the clumsiness of the Roman numerals in this particular, but these were superior as a means of computation to the numerals of the Greeks. Only one who has followed the history of mathematics in relation to physical science can appreciate the advances in knowledge which have been made possible by the introduction of the decimal point and the figure zero of our present Arabic numerals.

Greek thought thus stamped itself upon the ancient world, through Macedonian imperialism, despite the failure of the Greek city-states to unite into a great nation. During the three centuries which preceded the Christian Era, Hellenic culture came to dominate the peoples of the entire region about the middle and eastern Mediterranean, and was influential even to Gibraltar and to the shores of the Indian Ocean. This Hellenistic Age (323-23 в. c.) established the cultural inheritance of the Roman Empire. The learning of the Roman Period was the learning of Greece. Having survived the attacks of the barbarians from the east, Greece was overthrown politically by internal strife and by the barbarism of early Rome. But she set her mark upon her conqueror. Hellenic philosophy, at its best, had banished the fear of malevolent natural forces. The finer spirits among the Greeks had lived in a harmony with the world which we of the present can well afford to envy. Although this harmony proved only a temporary solution of the problem, it is the hope of modern life that mankind will eventually establish, through science, a harmony which shall rest upon a surer foundation.

\section{UTILIZATION OF SCIENCE BY ROME}

The racial sources of the original Romans are not so clearly traceable as those of the Greeks. There seems 
again to have been superposition of a Nordic element upon a Mediterranean one. But the fusion was more complete. The sunny shores of the Middle Sea attracted the barbarian long before the centuries during which Roman legions held back the northern hordes. A transition occurred in Italy as well as in Greece from the simple unimaginative standards of neolithic culture to the luxurious and thoughtful tastes of civilization, under the influence of Egypt, Mesopotamia, and Crete. Later, the Hellenic culture became dominant in the intellectual life of Rome.

In contrast to the Greeks, the Romans were active in the practical application of science rather than its theoretical extension. Their cultural contribution was government and the internationalizing of civilization. Rome was, however, a bulwark against the barbarians, and thus made possible a further development of science in Alexandria and in the lesser centers which preserved the Greek tradition. Again there occurred a great advance in the material aspects of civilized life, this time in the means of communication and transportation and in the stabilizing of the entire civilized world. But through it all, the Roman was not distinguished for originality in science or philosophy. Interest in nature seems to have consisted mainly in the practical applications of principles already ascertained. After two centuries of peace, following the conquests, Roman genius was still imitative in speculative science.

Energy and fortitude, prudence, endurance of long and arduous labor for the sake of ultimate gain, and hence an unremitting toil, practical sense, and capacity to profit by experience were distinctive Roman characteristics. The Greek ideal of a noble enjoyment of leisure and the pursuit of knowledge was but superficially comprehended by the majority of cultured Romans. ${ }^{22}$ The influence of racial traits is a possible key to the situation. The Roman by nature was practical and utilitarian rather than philosophical ${ }_{22}$ Taylor, H. O., "Ancient Ideals," Chap. XII. 
and speculative. Mechanical inventions were developed in many instances, but Rome more and more neglected the aspects of Hellenic learning which might have advanced science. Compendiums were produced during the later empire, containing information regarding arithmetic, geometry, astronomy, and the like. The knowledge of nature, accumulated in Greece, passed over into Italy and throughout the Roman Empire. But the creative scientific spirit did not flourish. The elder Pliny illustrates the Roman mind in its scientific development. His work upon natural history exhibits a lively interest in biological nature, but also the borrowing by which the intellectual life of Rome sustained itself from that of Greece.

Many individuals, who attained distinction in intellectual lines during the Roman Period, were not of Roman stock. Galen the Roman physician, whose knowledge of human anatomy dominated Europe throughout the Middle Ages, was a Greek by birth and not a Roman, although resident in Rome during his later years. He was, moreover, trained to dissection at Alexandria and in the rival center of medical learning at Pergamum, a Greek city of Asia Minor. He became a worthy successor to Hippocrates. Ptolemy of Alexandria (c. 127-151 A. D.), also a Greek rather than a Roman, became an authority in astronomy and geography, whose hold was only loosened by the Copernican Theory and by the voyages of discovery. We have already described the Museum of Alexandria, founded before the Roman conquest and continuing in existence during the first four centuries of the present era. The inception and later continuation of this institution were alike the product of Greek and not of Roman genius, although its progress was not discouraged by the Roman culture. Its domination by scholars of Greek descent, illustrates the persistence of Hellenic influences.

The practical scientific accomplishments of the Romans are seen in their adaptation and development of practical 
inventions and in their scientific organization of military affairs. Bridge and road building proceeded in a systematic fashion not unlike modern engineering. The construction of aqueducts and other public works, if less arduous than pyramid building, nevertheless exhibits greater aptitude in the application of scientific principles. The mechanical devices of the Hellenistic Age were improved and widely applied.

The writings of Titus Lucretius Carus (96-55 B. c.) ${ }^{23}$ represent the highest level of Roman genius as applied in synthetic and speculative thought. Lucretius seems to have derived his initial inspiration from Greek sources. In his famous didactic poem "De Rerum Natura," he elaborates the ideas of Democritus regarding the origin of the cosmos from atoms in motion. But he becomes more definite. The progressive development of life from mother earth by spontaneous generation, and the origin of man from brutish ancestry are proposed. The origin of language from animal sounds and of religious ideas from dreams is conjectured. The idea of selection in a struggle for existence is vaguely suggested. Above all, Lucretius is notable for his grasp of speculative ideas and their application to human life and nature. His great aim was the liberation of mankind from superstition and from the fear of death. He was not atheistic and Epicurean in the sense often supposed. Happiness through self-control and a feeling for the dignity of human life were his ideals. His attempt to synthesize knowledge and establish a sound philosophy of life represents the most comprehensive effort of the Greco-Roman world in this direction. By a refinement of the Epicurean philosophy, he believed that man could find an harmonious solution to the problem of existence. Despite the limitations of ignorance, his interpretations of human life and of nature resemble those of modern science. His mind runs in the scientific channel. The conflict between superstition and the laws of nature is 23 "Lucretius on the Nature of Things," translation by H. A. J. Munro. 
clearly presented. He has been maligned as a pagan, but his ideas find a sympathetic response at the present day. Thus the Christian Era dawned upon a world in which science had made a noble beginning, although the ancient learning had begun its decline. 


\section{CHAPTER III}

\section{THE DECLINE OF ANCIENT LEARNING}

Whatever the causes for its decline, the scientific spirit, which had made a favorable beginning in the ancient world, gradually disappeared with the oncoming of the Medieval Period. From the time when the pagan schools were finally closed until the Renaissance in Italy, the history of science is largely a blank among the Christian nations, in so far as the production and promulgation of new ideas is concerned. On the scientific side the Middle Ages are at their worst. From a scientific point of view the period may be fitly called the "Dark Ages." It is not surprising that the scientist has been harsh in his criticism of the mental attitude of mankind during a period which was everywhere dominated by blind faith and by ignorant prostration before the authority of the Church. But the artistic and literary accomplishment of these centuries and their final issue in the Modern Period should not be disregarded.

DECLINE OF SCIENCE DURING THE EARLY CENTURIES OF THE CHRISTIAN ERA

The religious beliefs of a people exert a far-reaching influence upon their philosophy and their science. Since the decline of science in the ancient world corresponds to the expansion of Christianity, we may ask whether there is evidence of a causal connection between these two historical events, whether there were not elements in the early Christian religion inimical to the growth of science or which hastened a decline already begun. Just as the freedom of the Greek religion favored scientific speculation, and the gloomy 
religious atmosphere of Babylonia retarded its growth, so the religious beliefs and practices of the early Christian centuries may have possessed qualities unfavorable or even hostile to the scientific spirit.

It has been widely believed, among those interested in science, that the advent of Christian dogma was mainly responsible for the decline of the ancient spirit of investigation. It is certainly true that the intellectual atmosphere, which came into existence during the first centuries of our era and which culminated in the Dark Ages, was one in which the rational analysis of natural phenomena became almost an impossibility. But there were many factors involved. Fundamental social changes were in progress, in the face of which the decline of science cannot have been solely due to dogmatic theology. The internal decay of the Roman Empire, the gradual change in the population from Roman and classical to Teutonic and Christian, were important factors in addition to the antagonism of Christianity to pagan culture. The barbarian invasions of the fifth and sixth centuries tended to obliterate the heritage of ancient learning. The intellectual backwardness of the Teutonic invaders, reinforced by the animosity of the Church, but gave the death blow to a culture which had already lost its initial inspiration and vitality. ${ }^{1}$

The decline of science was but one aspect of the collapse of the Roman world. The entire social and economic situation must be taken into account. The period of the Hannibalic or Second Punic War (218-202 в. с.) may be regarded as the summit of Rome's spiritual achievement. Conquest and material greatness came in the centuries which followed. But the seeds of an internal decay had germinated before the opening century of the Christian Era. As we have seen, the Romans made no important additions to the intellectual legacy which they derived from the earlier civilizations,

'Uhlhorn, G., "The Conflict of Christianity with Heathenism." Also: Taylor, H. O., "The Classical Heritage of the Middle Ages." 
excepting only along lines of government and law. The intellectual decline of Greece began with the collapse of her political influence, despite the extension of Greek culture during the Hellenistic Age. The apex of the curve had been reached by the ancient learning before the first century A. D. Christendom inherited from Greece and Rome a philosophy already divorced from the sure ground of science. We have seen how the cultural, and perhaps racial, traits of the Romans prevented the complete assimilation of the Greek spirit of investigation. It is important that this replacement of the scientific spirit by the ignorance and superstition, which culminated in the Dark Ages, was in progress during the two centuries that preceded the Christian era. At the most, Christianity but hastened what was already begun.

The causes of the disintegration of the Roman Empire, while the subject of much controversy, have become tolerably clear to the historian. ${ }^{2}$ Notable among them was the failure of Rome to use and to extend scientific knowledge. In her feats of engineering and architecture, she did indeed utilize and develop the knowledge of an earlier day. But in agriculture and in the more difficult field of social phenomena she failed to establish an enduring civilization. The scientist of to-day is particularly interested in some of the biological factors which seem to have been involved. From the standpoint of heredity there are signs of a physical degeneration resulting from the elimination of the more competent human strains by war, by the administration of distant provinces, and by the race-suicide and general deterioration

${ }^{2}$ The terrible picture of the degenerate spiritual life of the capital is pictured by Uhlhorn, Chap. II, loc. cit. Specific evidence of physical degeneration is suggested by the fact that portrait busts and statues of the last centuries of pagan Rome, which are still extant, "display an increasing ugliness. Their forms look unhealthy, either bloated or shrunken," p. 313. Also: Adams, G. B., "Civilization during the Middle Age," 77-88, for a well considered résumé of the complex of factors involved in the decline of this race which was the strongest the world had then produced. 
incident to a luxurious standard of living. Disease, particularly malaria ${ }^{3}$ and soil-exhaustion, along with the unwholesome economic conditions of slavery and of an over-developed urban life, were environmental factors that contributed to the decadence alike of ideals and of physical vigor. ${ }^{4}$ Rome squandered the accumulated savings of the earlier Mediterranean civilizations, and when the bank was empty she possessed neither the racial stamina nor the material resources to longer resist the barbarians. Appreciation of the significance of scientific knowledge in the perpetuation of any civilization might have saved the day. But if we of the twentieth century fail to appreciate the possibilities involved in man's squandering of the resources accumulated by nature during millions of years, and also the signs of our own deterioration, we need not marvel that Rome did not appreciate the possibilities inherent in the scientific achievements of the ancient world. ${ }^{5}$

Having thus recognized the decline of science as an incident in the collapse of the Greco-Roman culture and not primarily due to the advent of a new religion, the specific infiuence of Christianity may be considered. The fact to be grasped at the outset is that the actual teachings of Jesus were ethical, not theological. What we have long designated as Christianity is in many respects a direct inheritance from paganism. The spread of its initial doctrines was due to their ethical idealism and to the appeal which the promise of a future life made to the afflicted and oppressed. Reorganization of society was proposed. Slavery was to be abolished, charity was created, self-sacrifice was inculcated. The brotherhood of all mankind was proclaimed. The unifica-

${ }^{3}$ Jones, W. H. S., "Malaria: A Neglected Factor in the History of Greece and Rome."

"Ferrero, Guglielmo, "The Greatness and Decline of Rome." The evils of Rome's excessive urbanization are here set forth at length.

${ }^{5}$ Ferrero, Guglielmo, "Ancient Rome and Modern America." The parallel between the urbanization in Rome and in the United States of America is here discussed in an interesting, if not wholly convincing, manner. 
tion of the civilized world in the Roman Empire and also the moral dissolution of Rome facilitated the rapid development to a position of power. Christianity was at the outset strictly a religion. In the first century A. D., men said "See how these Christians love one another." But theological controversy soon intervened, and in the fourth century, it was said "There are no wild beasts so ferocious as Christians who differ concerning their faith." 6 After the third century, the new faith became largely a set of intellectual propositions. The victory in matters temporal was a triumph of paganism as well; for it consisted in an accession to pagan power and in an absorption of heathen beliefs and customs of ancient origin. Thus, Mariolatry, the Doctrine of the Trinity, Image Worship, and other widely accepted aspects of later Christianity can be traced to pagan origins which far antedate the Christian Era. It is important for Christianity in our own day that we distinguish between the doctrine which Jesus seems actually to have taught his disciples and the heterogeneous mass of pagan traditions with which the original nucleus soon became encrusted and which many still regard as essential features in the religion of the Occident.

The decline of the scientific spirit during the early Christian Era was due, primarily, not to prohibitions of the theologians, but rather to a change in mental attitude of the Mediterranean population, and to the intellectual backwardness of barbarian peoples from the north and west. In correlation with this changing point of view we find: philosophy becoming a part of religion, and hence intolerant of changes in the established system; salvation, in another world, coming to be regarded as the chief end of man; the second coming of Christ and the end of the world being expected at any time, and hence a failing interest in the visible universe. "To discuss the nature and position of the earth," says St. Ambrose, "does not help us in our hope of the life to

\footnotetext{
"Lerky, W. F., "History of Rationalism in Europe."
} 
come." "It is not through ignorance, but through contempt of such useless labor that we think little of these matters and turn our souls to better things," writes Eusebius. "It is a matter of no interest to us," writes Basil, "whether the earth is a sphere or a cylinder or a disc." These and many similar pronouncements are representative of prevailing convictions that were unfavorable to scientific progress.

As time went on, the dogma that the Scriptures were the direct word of God to man, to be interpreted as literally true in all respects, led to the doctrine that anything in conflict with Biblical statements was sinful; and further, that promulgation of such an error should be punished. The famous saying of St. Augustine, "Nothing is to be accepted save on authority of Scripture, since greater is that authority than all the powers of the human mind," came to be the basis of faith; and in this atmosphere of blind belief it is small wonder that ignorance reigned. The idea of God's will as the source of all causation was fostered by the doctrine of the inscrutability of God's ways to man, while always and everywhere there was a tendency to warp facts to fit theological conceptions. In brief, the Scriptures, and not the book of nature, became the authority in the interpretation of natural phenomena, while the existence and overwhelming importance of supernatural phenomena were accepted as a matter of course. ${ }^{7}$

${ }^{7}$ The following pagan characterization of the Christian view of knowledge illustrates the existence of a measure of active hostility to knowledge: "The Christians passed with the heathen as a race averse to all that is great, fair and noble in our humanity, as even hostile to it, and haters of mankind. In its origin their religion was barbarian: they despised all science. This is the rule laid down by them, writes Celsus: 'Let no one come to us who has been educated, or who is wise or prudent, for such qualifications are deemed evil by us; but if there be any ignorant, or uncultivated, or unintelligent, or foolish person, let him come with confidence.' Their teachers, he affirms, say: "See that none of you lay hold of knowledge! Knowledge is an evil. Knowledge causes men to lose their soundness of mind; they perish through wisdom.". Uhlhorn, G., loc. cit., p. 229. 
In such an environment it was inevitable that science and rational philosophy should languish, and steadily decline with the extension of the spiritual and temporal power of the medieval Church. ${ }^{8}$

It is interesting to find that this mental attitude was not universal. The ideas of Origen (c. 185-253 A. D.), a Greek Christian of Alexandria, bear some resemblance to those of modern Higher Criticism, in that he denied the exact and literal meaning of certain passages of the Scriptures. He was, moreover, opposed to the doctrine of damnation and hell. But these beliefs brought persecution during the lifetime of Origen and were anathematized in 553. Had they triumphed, in the absence of the allegorical interpretations to which Origen gave credence and which were later extended to a ridiculous degree, the evolution of Christianity might have taken a different course. Synesius, a pupil of Hypatia of Alexandria and who afterwards became Bishop of Cyrene, although accepting Christianity, declines to surrender his freedom of thought. In a statement of his difficulties in accepting the appointment of bishop, he writes as follows: "I must insist upon one other point, beside which all other obstacles are as nothing. It is difficult, if not altogether impossible, to eradicate from one's soul those convictions which have been gained by means of science. You know that philosophy rejects many of those dogmas which are generally accepted as true. I could never persuade myself, for example, that the soul was of later origin than the body; nor would I ever say that the world or any of its parts is doomed to destruction; the resurrection, an object of common belief, is for me only a sacred allegory and I am far from accepting the views which are ordinarily held." 9 This declaration was like a dying challenge of Greek thought to the gathering spirit of blind belief and superstition. The murder of Hypatia, by a rabble of fanatics (415), was one of

${ }^{8}$ White, A. D., "A History of the Warfare of Science with Theology."

${ }^{9}$ Quoted from the article by C. A. Browne, cited in the preceding chapter. 
the final steps in the obliteration of the ancient spirit of rationalism. There are also instances of opposition, by whole groups of individuals, to this spread of blind faith with its consequent ignorance. Gnosticism, although not, as is often erroneously supposed because of its name, a creed of the efficacy of natural knowledge, was nevertheless more acceptable than Christianity to individuals of scientific mind, in Alexandria and elsewhere. But eventually these opposing beliefs seem only to have hastened the consolidation of doctrines which triumphed as the Christianity of Rome and of Constantinople. Thus it appears that early Christian theology was antagonistic to scientific thought and knowledge and, while not the sole cause of the decline of science, helped to bring about an age of ignorance.

\section{THE DARK AGES OF SCIENCE}

The period from the close of the fifth century to the beginning of the Renaissance in Italy was one of gradual assimilation into the life of western Europe of new forces and factors. The Teutonic invaders, who had overrun the western portion of the Roman Empire, were on a cultural level not much above the best of the North American aborigines. They and their culture became, for the time being, the dominant factor in the western world. Greece and Rome, Christianity and the Teutonic barbarians were the immediate sources of our western civilization. The important service of the Church, which is not always recognized, was her influence upon the barbarians. Christianity became the intellectual power of the world. The Church was mainly responsible, despite other influences, for the gradual reconstruction of society, which made possible the return to scientific thinking. "To make out of the barbarized sixth century, stagnant and fragmentary, with little common life, without ideals or enthusiasms, the fifteenth century in full possession again of a common world civilization, keen, 
pushing, and enthusiastic. This was what the Middle Ages had to do, and this was what they did." 10

It is difficult for the scientist to understand the intellectual outlook of the Middle Ages. Society was dominated, during the greater portion of the period, by theological ideas. Interest in secular studies had been obliterated. Belief in the Bible, as the direct word of God to man, gave rise on the one hand to allegorical and on the other to intensely literal interpretations of the Scriptures. Obsessed with the belief in allegories, men sought for occult meanings in nature, as well as in the Biblical phraseology. The habits of animals, the characteristics of birds, reptiles, plants, and various natural objects such as stones and minerals were supposed to possess a spiritual significance and to carry with them lessons in conduct or morality. The people were credulous, and stories of weird animals, like the phœnix and the unicorn together with even stranger stories of real animals, were received without question. ${ }^{11}$ In biological science, the accounts of animals appearing in the "Physiologi" or "Bestiaries" are further examples of these forced interpretations. ${ }^{12}$ Even when the scriptural statements were matter-of-fact and easy to understand, allegorical explanations were often employed, or, if a natural explanation was used, the application to current events was frequently made with a literalness that now seems absurd. This state of

${ }^{10}$ Adams, G. B., "Civilization During the Middle Ages," p. 11.

11 The subsequent medical doctrine of signatures, by which the fancied resemblances in shape or color between objects in nature and the parts of the human body were held to be divine indications of the medicinal values of certain plants or minerals, was an outgrowth of this belief in the allegorical significance discoverable in the works of the Creator.

12 The writings generally known under the title "Physiologus" or "Bestiarius" were the most important source of knowledge concerning animals during the Medieval Period. They seem to have originated in the utilization of natural history as a means of enforcing Christian doctrines. For almost a thousand years these mystical and symbolic interpretations of animals mentioned in the Bible and others of a purely mythical character continued as an authoritative source of information. See: Carus, J. V., "Geschichte der Zoologie," Munich, 1872. 
mind, which was so well established during the early centuries of the Medieval Period, has not become extinct even in our own times. ${ }^{13}$

The work of Cosmas (c. 535 A. D.), entitled "Christian Opinion Concerning the World," well illustrates this medieval attitude in the interpretation of nature and also the existing state of geographical and astronomical knowledge. Cosmas set out to refute, among other heresies, the existence of the Antipodes. But his work was of a comprehensive nature and proclaimed itself "a Christian topography of the universe, established by demonstrations from Divine Scripture, concerning which it is not lawful for a Christian to doubt." His conclusions regarding the said topography are interesting, as summarizing the ideas then current. ${ }^{14}$ But his

${ }^{13}$ A nineteenth century example of this manner of reasoning, cited in Lecky's "History of Rationalism," runs as follows: "a geologist deeply impressed with the mystery of baptism-that mystery by which a new creature is formed by means of water and fire-would never have fallen into the absurdities of accounting for the formation of the globe solely by water or solely by fire. He would have suspected that the truth lay in the union of both." Modern geology, of course, acknowledges both fire and water and also other agencies as causcs in the evolution of the earth's surface, but not on grounds of allegorical mysticism.

14 "According to Cosmas, the world is a flat parallelogram. Its length, which should be measured from west to east, is the double of its breadth, which should be measured from north to south. In the centre is the earth we inhabit, which is surrounded by the ocean, and this again is encircled by another earth, in which men lived before the deluge, and from which Noah was transported in the ark. To the north of the world is a high conical mountain, around which the sun and moon continually revolve. When the sun is hid behind the mountain, it is night; when it is on our side of the mountain, it is day. To the edges of the outer earth the sky is glued. It consists of four high walls rising to a great height and then meeting in a vast concave roof, thus forming an immense edifice of which our world is the floor. This edifice is divided into two stories by the firmament which is placed between the earth and the roof of the sky. A great ocean is inserted in the side of the firmament remote from the earth. This is what is signified by the waters that are above the firmament. The space from these waters to the roof of the sky is allotted to the blest; that from the firmament to our earth to the angels, in their character of ministering spirits." Lecky, W. E. H., "History of Rationalism in Europe." The diagram of the universe as conceived by Hebrew thought (Fig. 22, in the present volume) may be referred to in this conncction. 
method of reasoning, by the adroit manipulation of phraseology and by an appeal to mysticism and allegory, is of greater importance for our present purpose as a key to the medieval state of mind. Cosmas reprimands those who are misled by Greek fables or the deceit of human science and who forget that the intimations of the nature of the universe contained in Scripture have far greater value and authority than anything which man can attain through his now unaided reason. He tells us that he would appeal "to the law and the testimony" and not to the writings of pagans. He disposes of the question of the Antipodes by strictly Biblical arguments, such as St. Paul's words that all men are made to live upon "the face of the earth," and therefore, could not live upon more faces than one or upon the back. Having such proof as this, a true Christian should not "even speak of the Antipodes." In discussing the structure of the universe, he takes the tabernacle of Moses as the model, because St. Paul refers to the earth as a tabernacle. Other examples need not be cited. His argument throughout is along these general lines.

The scientist does not profess to a sympathetic treatment of the Middle Ages, ${ }^{15}$ although he recognizes the value to mankind of mental attitudes which are unscientific. Some of the specific traits of medieval man which impress us as significant in relation to science are: his ideas regarding the taint of sin, that was assumed to be inherent in nature; the belief in the damnation of the unbeliever, and its outcome in persecution and the suppression of all spirit of criticism; the constant suggestion of the infinite not in terms of the unfathomed depths of science but in terms of mysticism; the dominance of emotionalism over rationalism; and the development of asceticism. ${ }^{16}$

${ }^{15}$ Taylor, H. O., "The Medieval Mind."

${ }^{10}$ The asceticism of the Middle Ages has been characterized as follows: "Beauty is a snare, pleasure is a sin, the world a fleeting show, man fallen and lost, death the only certainty, judgment inevitable, hell everlasting, heaven hard to win, ignorance acceptable to God as a proof of faith and submission, 
Despite all this, it is unfair to this important period of European history to suppose that its science amounted to nothing more than what could be gleaned from tradition and later an infusion from the Arab learning. The scientific knowledge of the past often seems curious and amusing in the light of the present. We forget how knowledge grows from half truths and sometimes from positive errors. For example, it is now universally acknowledged among intelligent persons that it is idle to regard the Scriptures as a source of scientific information. Nevertheless the most interesting and original constructive work of the Middle Ages, in the field of science, was done on the basis of evidence furnished by the Bible. This may be illustrated by the work of Cosmas to which we have previously alluded. The point is, that the men who desired to know something of natural phenomena, turned to the supposed source of wisdom in the Written Word. The efforts of the medieval scholar who struggled under the cloud of supernaturalism are pathetic and not ridiculous. In spite of the prevailing doctrine, the Middle Ages produced a number of enlightened scientific thinkers as well as sane men who condemned the popular errors and beliefs.

Occasional men and events prove that there was intellectual progress in spite of persecution and a stifling mental atmosphere. St. Augustine (354-430), with all his orthodoxy, seems to have doubted some of the current beliefs; for he explicitly declared that neither good nor evil necessarily flowed from the conjunction of the planets; and from time to time men of real scientific attainments came to the fore. Charlemagne's reformation of the Church was a period of intellectual culture which has been characterized as an "Earlier Renaissance." 17 Agobard (779-840), an

abstinence and mortification the only safe rules of life: These were the fixed ideas of the ascetic medieval church." Symonds, J. A., "Renaissance in Italy."

${ }^{17}$ Burckhardt, Jacob, "The Civilization of the Renaissance in Italy." 
archbishop of Lyons, attacked popular superstitions such as belief in witchcraft and the ordeal of fire. His point of view was theological rather than scientific, but he exhibits a clear intellect and an independent judgment. Gerbert of Rheims (940-1003), afterwards Pope Silvester II, was a master of the knowledge of his day, and was reputed to be the ablest mathematician and mechanician of his time. Educated in the science of the Arabs in Spain, he became the head of a famous school at Rheims. He obtained great reputation as a scientist, but because his science was rationalistic in character and because his knowledge was so far in advance of his associates he was suspected of being in league with the Evil One. He was the first to use the Arabic numerals and he also invented a timepiece which was regarded as wonderful in its day. But to the Middle Ages he was a magician and a sorcerer whose tomb grew moist and whose bones clattered whenever a pope was about to die. The mystic, Joachim of Flora (1145-1202) seems to have caught a glimpse of a better future for mankind on this earth when he proclaimed that "the Gospel of the Father was past, the Gospel of the Son was passing, the Gospel of the Spirit was to be," although his Age of the Spirit was to be one of contemplation rather than action. Abelard (1079-1142) protested against the state of mind which ascribed too great significance to mere words.

But the isolated individual had little influence upon the current of the times. Minds no doubt rebelled of whom we have no record. The effect of the persecutions must have been frightfully selective both as to rational ideas and as to individuals capable of developing them. The Middle Ages fulfilled their task of the cultural unification of Europe, but, as Burckhardt puts it, "if those elegaic natures which long to see them return could pass but one hour in the midst of them, they would gasp to be back in modern air." Selfconfidence was lacking, life was hard and there was scant joy in living. The terrors of another world beyond were added 
to those of the present. Men lived with no extensive knowledge of the past and with no conception of the possibilities held in store by the future.

A constructive side of the period, in relation to science, is seen in the preservation of the older learning and in the protection afforded to scholars by the monasteries. Knowledge of the ancient world descended in manuscripts that were preserved by the Church, though not widely known until the Revival of Learning. This service of conservation was of inestimable value, despite the pious frauds of the copyists which cast suspicion upon the accuracy of many of the writings transmitted. As to the protection of scholars, it appears that the monasteries and cathedrals were the only places, in which there was opportunity for the practice of scholarly pursuits, during the welter of social and economic unrest of the five centuries that followed the year 500 A. D., since they offered the first opportunity for an intellectual life protected from the turmoil of the world. The celibacy of the clergy was unfortunate, in so far as it tended to check the reproduction of minds capable of intellectual attainment. But the intellectual and ethical idealism of the monastic life, when at its best, was a potent factor in the eventual development of a greater measure of intellectual activity. The universities of Europe arose in intimate union with the scholarly activities of the Church and clergy. In biological science, the knowledge of medicine was transmitted, if not extended, because of the service of religion to the afflicted. In these respects, the Middle Ages appear as the conserver of the older learning and to some extent the protector of the new.

\section{INFLUENCE OF THE ARAB CIVILIZATION}

Leaving Europe, we now turn to another continent and to another race which inherited and extended the ancient learning in science. The Arabs, during their century of con- 
quest (650-750 A. D.), had expanded their empire, not only throughout the Mesopotamian region, but to India on the east and westward along the southern shores of the Mediterranean until they occupied Spain. In the East, they came into contact with the tradition of Greek science in Asia Minor and at Alexandria, and with the mathematical science of the Hindus in India. In the West, they threatened to overrun Europe both in Spain and at Constantinople. In contrast to the intellectual backwardness of the northern barbarians, who conquered the Roman empire, the Arabs showed an immediate aptitude for the older learning. Their civilization exhibited an intellectual quality, particularly along scientific lines. At a time when science seemed hopelessly lost in Christendom, they quickly assimilated the learning of the ancient world, and also received with enthusiasm suggestions from other sources. In Spain, the Moorish Kingdom attained a cultural and material level above anything that existed in Europe before the Italian Renaissance. Paved and lighted streets, running water, architecture of wonderful grace, public libraries, the encouragement of literature and science, and a spirit of toleration were the marks of a civilization that was remarkable for its intellectual superiority.

In their earlier conquests the Arabs exhibited the spirit of the barbarian. They destroyed libraries and other works of civilization. ${ }^{18}$ But within a century they were establishing colleges and collecting manuscripts. The court of the Khalifate of Al-Mamun (813-833 A. D.) at Bagdad became an intellectual center rivaling ancient Alexandria. Schools were attached to the mosques throughout the empire. At Bagdad and elsewhere there were colleges for the higher branches. A surprising toleration prevailed, as shown by the

${ }^{18}$ The Khalif Omar is said to have replied, to a request that he spare the remnant of the great Alexandrian library, "If the books agree with the Koran, the Word of God, they are useless, and need not be preserved; if they disagree with it, they are pernicious. Let them be destroyed." And the story is that the books were distributed as fuel to the baths of the city. 
frequent commission of the superintendence of these schools to Nestorian Christians or to Jews. "It mattered not in what country a man was born, nor what were his religious opinions; his attainment in learning was the only thing to be considered." 19 The medical colleges at Cairo in Egypt and at Salerno in Italy, and the astronomical observatories in Spain were centers from which a quickening influence extended to Europe. The Arabs for a time succeeded, where the Greeks had failed, by recognizing the sure ground of generalization based upon observation and experiment as opposed to speculation. Their work in many lines exhibits a surprising aptitude for scientific investigation. While not making revolutionary discoveries, they performed inestimable service in preserving and consolidating the ancient knowledge in scientific lines. The ancient learning, inherited at Alexandria and elsewhere, was passed over to Europe in far better condition than when the Arabs received it at the eastern end of the Mediterranean.

The Arab predilection for experimentation appears in the fact that his conclusions were almost invariably based upon an experiment or an instrumental observation. Thus the foundations of modern chemistry were laid; while in astronomy and physical science instruments and apparatus were developed. The adoption of the Indian numeration in arithmetic greatly facilitated calculation and surprising progress was made in the mathematical sciences, particularly in algebra, which was received from the Hindus but was elaborated by the Arabs into its present form. Astronomical tables of eclipses and the like were extensively developed. The forerunners of modern surveying instruments were invented. The specific weights of many chemical elements

19 The Khalif Al-Mamun declared that scholars were "the elect of God, his best and most useful servants, whose lives were devoted to the improvement of their rational faculties; that the teachers of wisdom are the true luminaries and legislators of the world, which, without their aid, would again sink into ignorance and barbarism." Quoted from: Draper, J. W., "History of the Conflict between Religion and Science." 
were approximately ascertained. Methods of distillation, filtration, and crystallization were elaborated. The circumference of the earth was calculated after several measurements of the arc of a degree on the surface. The principal of position in numbers and the idea of infinite series were received, like Algebra, from the Hindus; and the so-called arabic numerals were likewise passed on to Europe, where they quickly superseded the clumsy Roman notation. The mariner's compass and gunpowder appear also to have reached Europe through Arab channels.

Among their great teachers, Avicenna (980-1037) wrote on medicine and became an authority in European schools for centuries; while Averroes (1126-1198), who was so largely instrumental in making known to Europe the works of Aristotle, became the greatest philosopher of the later Middle Ages. Anticipating the Renaissance, the Arab seemed to catch the Greek spirit of the individual as opposed to the horde composing the race, and to grasp the subjective in the midst of the objective. It is, doubtless, indicative of an unrecorded survival of the ancient learning in Alexandria, after the destruction of the Museum, that Arab science advanced along the very lines that were highly developed by the Museum during the Hellenistic Age and the early centuries of the Christian Era.

The turning point in the intellectual development of Europe came about the year 1200. It is significant that Arab science began its more intimate contact with Europe during the preceding centuries. In general, the Arab culture was much more important in southern Europe during the Middle Ages than during the Renaissance. It appears that most of the scientific ideas of the later Middle Ages, of any value in mathematics, astronomy, geography, medicine, and natural history, are traceable directly or indirectly to the Arab learning. Men like Gerbert of Rheims and Roger Bacon seem to have owed their initial knowledge and inspiration to this source. Despite their superstitious quests for 
the elixir of life and the philosopher's stone, the Arabs built up a fairly solid body of scientific knowledge upon the foundation acquired from the ancient world. Arab science must, therefore, be regarded as the most important bond of continuity between the science of antiquity and that of modern times. In this account of the services of an alien race to the development of European science, may also be mentioned the services of the Jews, who were the chief interpreters to Europe of the Arab learning. They seem to have been second only to the Moors of Spain in their cultivation of natural science. But this may have been due merely to the fact that the Arab learning was more accessible to the Jews because of their commercial activities. ${ }^{20}$

The Arabs, with their dawning appreciation of science, might have won to power throughout Europe, had not internal dissensions produced a division of their Empire and had not the accession to power of barbarian Turks and Berbers in the East interposed a final check upon their scientific progress. The influence of Arab culture upon the intellectual life of Christendom was more lasting than its influence upon the life of Islam. Contact with Arab civilization, through the Crusades, through the commerce of the Mediterranean, and more directly in Spain and at Constantinople, aroused in Europe a zeal for the science and literature of antiquity. Arab science was, therefore, one of the most important cultural influences during the later Middle Ages.

\section{THE APPROACH TO MODERN SCIENCE}

It is a mistake to suppose that the Renaissance, which is now recognized as the period at which modern science

${ }^{20}$ The history of the Arab and the Jew in relation to the origins of modern scientific ideas seems never to have been adequately studied by the historian. Enough is known of the facts to indicate the importance of the contributions thus made, but further historical investigation would doubtless yield many interesting details. 
began to be firmly established, was either a mere revival of the ancient science or a miraculous development of the new. We find in the Renaissance many survivals of medieval superstitions and we likewise find in the late Middle Ages the mental stirrings which presage the Renaissance. It is a truism to say that every age has its roots in the past, but in the face of striking cultural changes, the antecedent factors are not always clear. Because of these indications of the new day, which appear during the last two centuries of the Medieval Period, the dawn of modern science is coming to be set about the year 1200, instead of during the Renaissance or at an even later date, as is done by those who assume that nothing important was accomplished before the nineteenth century. We have considered some of the scattered indications of a more scientific attitude during the Middle Ages and also the nature and influence of the Arab learning. We may now consider certain men and events that evidence the dawn of science during the thirteenth and fourteenth centuries.

By the opening of the thirteenth century, certain elements of stability had appeared in Europe which had not been in existence since the period of the Roman Empire, although the Empire of Charlemagne came near to their realization. The northern barbarians had been finally checked and in part absorbed, the Christian nations had been unified by the influence of the Church of Rome, and the governments of the existing European states had become sufficiently strong to preserve order. The irrational state of mind characteristic of the Middle Ages was still dominant, but the influence of Arab science was being felt and individuals who struggled against the prevailing current became more numerous. Thus Albertus Magnus (1193-1280) appear's as the earliest botanist. In addition to other botanical studies, he examined the artificial propagation of plants in a hothouse attached to his convent garden. He also made numerous chemical experiments and first used the chemical term af- 
finity in its modern scientific sense. In the field of natural history, he dissented from the then accepted belief "that certain birds spring from trees and are nourished by the sap, and also from the theory that some are generated in the sea from decaying wood." 21 His studies on the influence of geographical features upon races and his position in opposition to those who ridiculed the existence of the Antipodes entitle him to a place as one of the founders of geographical

21 White, A. D., loc. cit., Vol. I, p. 37.

The name goose-barnacle, which survives in modern zoölogy, arose in connection with this belief.

For example, Sylvester Giraldus, in his "Relations concerning Ireland," (1187) writes as follows: "Chapt. II, Of Barnacles which grew from fir timber and their nature."

"There are likewise here (in Ireland) many birds called barnacles, which nature produces in a wonderful manner, out of her ordinary course. They resemble the marsh geese, but are smaller. Being at first gummy excrescences from pinebeams floating on the water, and then enclosed in shells to secure their free growth, they hang by their beaks, like seaweeds attached to the timber. Being in process of time well covered with feathers, they either fall into the water or take their flight into the free air, their nourishment and growth being supplied, while they are bred in this very unaccountable and curious manner, from the juices of the wood in the water. I have often seen with my own eyes more than a thousand minute embryos of birds of this species on the sea-shore, hanging from one piece of timber, covered with shells, and already forıned. No eggs are laid by these birds . . .; the hen never sits on eggs in order to hatch them; in no corner of the world are they seen either to pair, or build nests. Hence, in some parts of Ireland, bishops and men of religion make no scruple of eating these birds on fasting days, as not being flesh, because they are not born of fiesh, but these men are curiously drawn into error. For, if any one had eaten part of the thigh of our first parent, which was really flesh, although not born of flesh, I should think him not guiltless of having eaten flesh. Repent, O unhappy Jew."

As late as 1676 this same belief was seriously maintained, when Sir Robert Murray reported his observations to the Royal Society of England: "In many shells I opened, I found a perfect Sea-Fowl; the little Bill like that of a Goose; the Eyes marked; the Head, Neck, Breast, Wings, Tail, and Feet, formed; the Feathers everywhere perfectly Shaped, and Blackish colored; and the Feet like those of other Water-Fowl, to my best Rememberance. The biggest I found upon the Tree, was but about the size of the Figure (an inch long); nor did I ever see any of the little Birds alive, nor meet with any Body that did; only some credible Persons have assured me that they have seen some as big as their Fist." (Quoted from Metcalfe, M. M., "Organic Evolution," published by the Macmillan Co. Reprinted by permission.) 
science. Like Gerbert of Rheims, he was regarded as in league with the Devil, but his ecclesiastical standing saved him from persecution.

The greatest of medieval scientists was Roger Bacon, born about the year 1214 and known as the "Admirable Doctor." Familiar with Latin, Greek, Hebrew, and Arabic, Bacon was well versed in the older learning, but more than this he was a man of new ideas. He seems to have practiced in the thirteenth century what Francis Bacon advocated in the seventeenth, proclaiming that man by the use of science could do all things. Realizing the danger of reliance upon traditional authority, he advocated the scientific method of critical observation and experimentation, and he shows throughout his work an insight into the spirit of modern science which is remarkable. Bacon placed mathematics first among the sciences. He was one of the first real astronomers in western Europe and his recommendation to Pope Clement II to rectify the calendar, as was done three centuries later, shows how far he was in advance of his time. He discovered the use of spectacles, described the use of the telescope and microscope, and foresaw the application of various optical devices to instruments for the measurement of angles. In a wonderful letter that has come down to us he practically foretells the steamship, the steam engine, the automobile, the suspension bridge, and the flying machine. His scientific imagination was great enough to rise above the practical limitations of his time and see into the future. Yet his greatest contribution was his insistence upon real reasoning and upon experiment and research into the workings of nature rather than subtilizing on empty propositions and fruitless study of Aristotle.

But the spirit of the times was averse to these ideas. Bacon was so much in advance of his age, that his inventions were regarded as "suspicious novelties." The leaders in church and state accused him of magical practices and of being in league with Satan. The ignorant minds of the age 
could not sustain new truths which were in opposition to the Bible and dogmatic theology. They cried "Atheist!", "Infidel!" and "Magician!"; and thus won the day. To his critics Bacon replied that "because these things are beyond your comprehension, you call them the works of the Devil, your theologians and canonists abhor them as the production of magic, regarding them as unworthy of a Christian."

Bacon's attempt to show that much which was ascribed to demons resulted from natural means merely added to the flame; for to limit the power of Satan was deemed hardly less impious than to limit the power of God. When he attempted to perform a few simple experiments before a select audience at Oxford the whole city arose in horror and alarm. A riot was precipitated; for all believed that Satan was to be summoned to appear. The news spread like wildfire and from every house rushed priests, lecturers, students, and townspeople crying "Down with the magician." When Clement IV, Bacon's friend and protector, died, Bacon was persecuted by the Church for his free views and finally thrown into prison where he spent over ten years, being released shortly before his death in 1294. Tradition has it that almost his last words were "would that I had not given myself so much trouble for the love of science." Europe was not to see such a true man of science for two centuries, at least, and no better criticism of the narrowness of medieval theology and the domination of irrational superstition can be cited than the treatment he received in his own life and by posterity which long failed to recognize his greatness in the intellectual history of Europe. ${ }^{22}$

The recovery of the complete works of Aristotle occurred during the second decade of the thirteenth century, first in Arabic translations and later in the original Greek. During the Middle Ages these writings had been known only in a

${ }^{22}$ Taylor, H. O., "The Medieval Mind," I, Chapter on Roger Bacon. White, A. D., loc. cit., I, pp. 387-391. Draper, J. W., "The Intellectual Development of Europe," II, pp. 153-55. 
fragmentary form. Being eagerly devoured by the schoolmen, they at once became a part of the traditional teachings, rather than a stimulus to a renewal of the Greek spirit of investigation. It is for this reason that the Ptolemaic astronomy and the science of Aristotle were looked upon with suspicion by many of the scholars of the Renaissance. The Arab influence is seen throughout these closing decades of the Middle Ages. Those who struggled against the established authority seem continually to have drawn inspiration from this source rather than from the ancient masters as interpreted by Europe. The philosophical aspects of the Aristotelian doctrines were set forth by the Spanish-Arabian scholar Averroes (1126-1198) and assumed such importance that the Church was at great pains to counteract them. Despite these attacks, the intellectual vistas that were being opened to Europe continued to unfold.

The union of science and theology, which had been criticized by Averroes, was further protested by Duns Scotus (1265-1308) and by William of Occam (d. 1347), the latter denying that theological doctrines were rationally demonstrable and showing the irrational nature of many of the current teachings. ${ }^{23}$ Thomas Aquinas (1227-1274), although a defender of orthodox theology, shows a more scientific spirit than many of his contemporaries, when he declares that "the object of the study of philosophy is not to learn what men have thought but what is the real truth of the matter." But Aquinas represents the spirit of Scholasticism rather than the spirit of science. He is admired at the present day as an earnest seeker after truth, possessed of great intellectual acumen but dominated by the prejudices of his age, rather than one whose ideas were in line with modern thought.

The culmination of distinctively medieval ideas is seen in the scholasticism of the thirteenth and fourteenth centuries.

${ }^{23}$ Whetham, W. C. D., and C. D., "Science and the Human Mind." Also: Taylor, H. O., "The Medieval Mind," Chap. XLII. 
Scholasticism is of interest to science as a sign of an intense intellectual activity and not because of its accomplishments. The harbingers of the modern spirit were not the theologians, but Roger Bacon, and the other scientist-philosophers of the thirteenth and fourteenth centuries, who seem to have drawn their knowledge and inspiration so largely from the Arab sources. As was emphasized at the beginning of the present chapter, the Middle Ages are not to be judged by their scientific accomplishment, but rather by their unification of a discordant world in preparation for the reëstablishment and extension of the scientific spirit of antiquity. These centuries were always lacking in the modern rationalistic spirit, being dominated by supernaturalism. Reasoning was taught and practiced as a form of mental gymnastics. The preëminence of theology attracted to theological studies minds that might better have been employed in science. The dominant thought at the close of the period was still without any clear conception of scientific reasoning. The true and the false were hopelessly intermingled. Facts "that would not be denied" were at length the means by which the rationalism of modern times triumphed over supernaturalism. 


\section{CHAPTER IV}

\section{THE EMERGENCE OF MODERN SCIENCE}

We think too much of the Renaissance as mainly characterized by literary and artistic revival and achievement. The history of science shows that the period was one of diversified activity and that its scientific achievements were even more important than those in other lines. It was during the Renaissance that science became securely established; and the scientific spirit of the modern world is but a continuation of the spirit which appeared in southern and western Europe during the fourteenth, fifteenth, and sixteenth centuries. The limits of such an historical period, of course, are arbitrary. In literature and art, the time at which the Renaissance culminates is recognized as differing in different countries. Considering science alone and the western world as a whole, we may apply the term to a period (1350-1700) which includes both the century of the awakening in Italy and also the centuries during which science became strongly established within the nations that succeeded Italy in the intellectual domination of Europe. During the Renaissance a thoroughly scientific spirit appears for the first time in history. For not only was the older learning recovered and rated at its true value, but there also occurred a new development of natural knowledge, which has brought forth the science of the present time.

MEDIEVAL ANTECEDENTS OF THE RENAISSANCE IN SCIENCE

The culture of the Renaissance, like that of ancient Hellas, was formerly regarded as a spontaneous development. But investigation has told us more of its origins. 
Like other historic cultures, it now appears as a natural outgrowth from preceding centuries. The Middle Ages culminated in the Renaissance by a natural process, and this historical fact puts a better face upon the Middle Ages. The Crusades, which were so distinctively a product of the medieval frame of mind, are now recognized as the precursors of the intellectual awakening of Europe. Beginning as a response to what was believed to be the call of God, they eventuated in developments that were of far-reaching importance along intellectual lines.

Such, for example, was the commercial development of the Italian cities, initiated by the transportation of the crusaders, and the consequent rise of an industrial aristocracy possessed of wealth and leisure. Contact with the infidels brought respect for their courage, their morality, and their learning. Mohammedan learning, which, as we have seen, had been filtering into Europe during the preceding centuries, became the basis for a renewed growth of science, although its influence was not generally acknowledged. The secularization of many activities tended toward greater intellectual freedom. New vistas were opened to the human mind, not only by the partial recovery of the ancient learning but also by geographical discoveries and by the renewed incursions within the field of natural knowledge. The maritime experiences of the Italians and their sudden economic advancement, along with the intellectual leadership of the Church at Rome, made the Italian peninsula the starting point from which the awakening spread westward and northward. We have seen that the dawn of European science dates from Roger Bacon and the thirteenth century. By the opening years of the fourteenth century, the spirit most typical of the Middle Ages had disappeared in the more progressive centers of the western world, and the time was ripe for the re-birth that was to follow. ${ }^{1}$

${ }^{1}$ Adams, G. B., "Civilization during the Middle Ages," Chapters XI and XII. 
Even scholasticism, the traditional spirit of which was so repellent to that of science, was a sign of the renewal of intellectual activity. The story of its development is a revelation of how human ability may be perverted and misdirected through limited knowledge. The schoolmen give evidence of great intellectual acumen, although so largely ignorant of the older learning and so mistaken in their concept of authority. Beginning in the abortive revival of the schools under Charlemagne, scholasticism culminated during the thirteenth century in a broader outlook, but still in conflict with the spirit which soon prevailed. The complete works of Aristotle became known between 1210 and 1225 and proved a wonderful stimulus. But the schoolmen were mainly content with the authority of Aristotle and the Scriptures in matters of natural knowledge. Only rare individuals among them, like Roger Bacon, recognized the authority of nature. Nevertheless, if their conclusions were false their systems of thought were comprehensive, and often scientific save for their premises. Many of their discussions revolved upon important problems in speculative philosophy which even to-day can be attacked only through speculation. Again, the older universities of Europe were established under the stimulus of scholasticism. When we understand that the great century of the schoolmen (1200-1300) was one of the most intellectual periods in all history, we recognize in scholasticism a prediction and an introduction of the age of new thought which followed.

The greater social stability, which appeared in western Europe during the twelfth and thirteenth centuries, the decline of papal authority, incident to the failure of the Crusades, the rise of national states, and the growing political freedom of the Italian cities were additional factors. When the whole situation is taken into consideration, there is abundant evidence of a changing outlook, during the final century of the Middle Ages. The spirit of other-worldliness was beginning to wane and the bonds of traditional authority 
were already loosened. Thus, the Renaissance appears as a product of the Middle Ages, and not merely as the ancient spirit restored to power.

It was necessary for the men of the Renaissance to become masters of the old. But the re-birth was not merely a revival of learning, it was a new creation as well. In science, at least, the Renaissance began where the older knowledge had reached the limits of its understanding. Here, for the first time, science found itself, came to take the ancient learning at its true value, and began to shape new courses. Philosophy became distinct, on the one hand from science and on the other from current theology. The authority of nature came to be acknowledged, and the rationalistic point of view was established in a manner distinctive of modern thought. During the first century of the Renaissance (1350-1450), many of the older beliefs and superstitions survived, and even flourished with renewed vigor, like the false sciences of alchemy and astrology. But with the growth of skepticism, rationalism more and more prevailed. Thus, through a critical attitude toward the old knowledge, the way was prepared for the development of more positive and constructive thinking after the middle of the fifteenth century.

DISTINCTIVE FEATURES OF THE SCIENCE OF THE RENAISSANCE

The terms Revival of Learning and Renaissance, which are both applied to this great period of European history, are descriptive of its best known features-the restoration of the older knowledge and the rebirth of its spirit. The ancient culture was restored to Europe in part by its survivals in Italy and Constantinople, ${ }^{2}$ and by transfer from the Arab

${ }^{2}$ The Greek tradition had survived continuously in Constantinople, but the limited means of communication during the Middle Ages and the lack of intellectual interest on the part of western Europeans rendered its influence unavailing. The fall of Constantinople in $\mathbf{1 4 5 3}$ is an overrated event from the point of view of culture, as the revival of the classics had already taken 
civilization. The Greek language had practically disappeared in Italy during the darkest centuries, but was recovered toward the close of the scholastic period. This revival of the older learning, which was effected mainly during the fourteenth and early fifteenth centuries, was a point of departure, but the distinctive feature of the Renaissance in science was the acquisition of factual knowledge that was wholly new and the change of spiritual outlook which this knowledge gradually forced upon mankind.

A feature of the Renaissance which is of more vital significance is that its intellectual development falls into two periods which form a natural sequence but which are rather clearly separated. From the early fourteenth to the middle fifteenth century the spirit was one of skepticism toward traditional explanations and a growing rationalism regarding scientific questions. After 1450 constructive thought was increasingly evident. During the earlier period many medieval superstitions survived and false sciences like astrology continued to flourish. During the later period these hindrances were removed by the increase of factual knowledge. By the close of the seventeenth century the calm and consciously rational spirit of science is seen among progressive thinkers, and thus the characteristic feature of the modern mind becomes established.

But the most distinctive aspect of the period under discussion was the widening of intellectual horizon and the resultant effects upon imagination. The science of the Renaissance is, therefore, in contrast with that of our own day which has been distinguished by its material achievements. During the Renaissance, man came for the first time to know himself and to know the world. The horizon of human experience became suddenly extended to an undreamed of distance. This spiritual influence of the new learning may be visualized by an exhibition, in tabular form,

place. However, it did bring to western Europe a number of scholars and some new manuscripts. 
of the more important factors which thus influenced the mind of Europe. In the tabulation, as given, the names of individuals commonly associated with particular factors appear to the left, while to the right is a phrase characterizing the factor in question.

FACTORS INFLUENTIAL IN WIDENING OF INTELLECTUAL HORIZON DURING RENAISSANCE OF SCIENCE (1350-1700)

IN GEOGRAPHICAL SCIENCE

\begin{tabular}{|c|c|}
\hline $\begin{array}{l}\text { Paolo Toscanelli } \\
\quad(1397-1482)\end{array}$ & Making of Map used by Explorers \\
\hline $\begin{array}{l}\text { Prince Henry, the "Navigator" } \\
(1394-1460)\end{array}$ & $\begin{array}{l}\text { Exploration of African Coasts, Discovery } \\
\text { of Madeira and the Azores }\end{array}$ \\
\hline $\begin{array}{l}\text { Bartholomew Dias } \\
\quad(1445-1500)\end{array}$ & Rounding Cape of Good Hope \\
\hline $\begin{array}{l}\text { Christopher Columbus } \\
\quad(1446-1506)\end{array}$ & Discovery of America (1492) \\
\hline $\begin{array}{l}\text { Amerigo Vespucei } \\
\quad(1452-1512)\end{array}$ & Naming and better Knowledgc of America \\
\hline $\begin{array}{l}\text { Vasco da Gama } \\
\qquad(1469-1524)\end{array}$ & Discovery of Sea-Route to India \\
\hline $\begin{array}{l}\text { Ferdinand Magellan } \\
\qquad(1480-1521)\end{array}$ & $\begin{array}{l}\text { Circumnavigation of Globe (1519-21), Es- } \\
\text { tablishment of Earth's Sphericity by } \\
\text { means of Geographical Evidence }\end{array}$ \\
\hline $\begin{array}{l}\text { Gerhard Kramer, "Mercator" } \\
(1512-1594)\end{array}$ & $\begin{array}{l}\text { More Accurate Map-Making of New } \\
\text { World, Introduction of Mercator's Pro- } \\
\text { jection }\end{array}$ \\
\hline $\begin{array}{l}\text { Gilbert of Colchester } \\
\quad(1540-1603)\end{array}$ & $\begin{array}{l}\text { Studies in Magnetism and Electricity, } \\
\text { Adoption and Development of Mariner's } \\
\text { Compass }\end{array}$ \\
\hline $\begin{array}{l}\text { Numerous Explorers and } \\
\text { Geographers }(1500-1700)\end{array}$ & $\begin{array}{l}\text { Detailed Exploration and Mapping of } \\
\text { Globe }\end{array}$ \\
\hline
\end{tabular}


IN THE MATHEMATICAL, ASTRONOMICAL, PHYSICAL, AND CHEMICAL SCIENCES

\begin{tabular}{l|l}
\hline $\begin{array}{l}\text { Lucas Pacioli } \\
(1450-\text { ? })\end{array}$ & $\begin{array}{l}\text { Rapid Development of Mathematical } \\
\text { Science following Adoption of Arabic } \\
\text { Numerals }\end{array}$ \\
\hline $\begin{array}{l}\text { Albrecht Dürer } \\
(1471-1528)\end{array}$ & $\begin{array}{l}\text { Geometrical Theory of Perspective De- } \\
\text { veloped in Connection with Artistic } \\
\text { Representation }\end{array}$ \\
\hline $\begin{array}{l}\text { Nicolas Copernicus } \\
(1473-1543)\end{array}$ & $\begin{array}{l}\text { Heliocentric Theory revived with Evidence } \\
\text { in its Favor }\end{array}$ \\
\hline $\begin{array}{l}\text { Tycho Brahe } \\
(1546-1601) \\
\text { Stevinus of Bruges }\end{array}$ & $\begin{array}{l}\text { Confirmation of Copernican Theory by } \\
\text { Telescope and Intensive Work upon } \\
\text { Galileo Galilei } \\
(1564-1642)\end{array}$ \\
\hline $\begin{array}{l}\text { Johann Kepler } \\
(1571-1630)\end{array}$ & $\begin{array}{l}\text { Accumulation of Adequate Data } \\
\text { Isaac Newton } \\
(1642-1727)\end{array}$ \\
\hline $\begin{array}{l}\text { Robert Boyle } \\
(1627-1691) \\
\text { Georg Ernst Stahl } \\
(1660-1734)\end{array}$ & $\begin{array}{l}\text { Discovery of Gravitation as the Law of } \\
\text { the Heavens }\end{array}$ \\
\hline Beginnings of Chemical Science \\
\hline
\end{tabular}


IN THE BIOLOGICAL SCIENCES

\begin{tabular}{|c|c|}
\hline $\begin{array}{l}\text { The Medical Humanists } \\
(1450-1550)\end{array}$ & $\begin{array}{l}\text { Revival of Writings of Hippocrates and } \\
\text { Galen }\end{array}$ \\
\hline $\begin{array}{l}\text { Philippus von Hohenheim, } \\
\text { "Paracelsus" (1493-1541) }\end{array}$ & $\begin{array}{l}\text { Teaching in Common Tongue, Increasing } \\
\text { Reliance upon Direct Observation, } \\
\text { Chemical Medicine }\end{array}$ \\
\hline $\begin{array}{l}\text { Andreas Vesalius } \\
\quad(1514-1564)\end{array}$ & $\begin{array}{l}\text { Establishment of Human Anatomy as a } \\
\text { Science, First Modern Textbook }\end{array}$ \\
\hline $\begin{array}{l}\text { Conrad von Gesner } \\
\quad(1516-1565)\end{array}$ & $\begin{array}{l}\text { Knowledge of Strange Animals and Plants } \\
\text { Collected from Remote Regions }\end{array}$ \\
\hline $\begin{array}{l}\text { William Harvey } \\
(1578-1657)\end{array}$ & $\begin{array}{l}\text { Discovery of Circulation of the Blood, } \\
\text { Growth of Physiological and Embryo- } \\
\text { logical Knowledge }\end{array}$ \\
\hline $\begin{array}{l}\text { Francesco Redi } \\
\text { (1626-1698) }\end{array}$ & $\begin{array}{l}\text { Disproof of Spontaneous Generation in all } \\
\text { but Microscopic Forms }\end{array}$ \\
\hline $\begin{array}{l}\text { John Ray } \\
\qquad(1628-1705)\end{array}$ & $\begin{array}{l}\text { Preliminary Steps toward Modern Classi- } \\
\text { fication of Plants and Animals }\end{array}$ \\
\hline $\begin{array}{l}\text { Marcello Malpighi } \\
\quad(1628-1694)\end{array}$ & $\begin{array}{l}\text { Increasing Knowledge of Animals and } \\
\text { Plants both Gross and Microscopic }\end{array}$ \\
\hline $\begin{array}{l}\text { Anthony van Leeuwenhoek } \\
\quad(1632-1723) \\
\text { Jan Swammerdam } \\
\quad(1637-1680)\end{array}$ & $\begin{array}{l}\text { Introduction of Microscope and Study of } \\
\text { Microörganisms }\end{array}$ \\
\hline
\end{tabular}




\section{MISCELLANEOUS FACTORS}

Laurens Coster

(1370-1440)

Johannes Gutenberg

(1397-1468)

Leone Battista Alberti

(1404-1472)

Leonardo da Vinci

(1452-1519)

Giovanni Pico della Mirandola (1463-1494)

Giordano Bruno

(1548-1600)

$(1500-1700)$

Michel Montaigne

(1533-1592)

Francis Bacon

(1561-1626)

Thomas Hobbes

(1588-1679)

Renć Descartes

(1596-1650)

Blaise Pascal

(1623-1662)

John Locke

(1632-1704)

Baruch Spinoza

(1632-1677)

Gottfried Leibnitz

(1646-1716)
Introduction of Printing from Movable Type (c. 1440)

Stimulus of Individuals of Universal Genius

Open Criticism of Dogmas of the Church, culminating in the Religious Toleration of Present Time

Economic Development stimulated by Beginning of Trade with World and continuing to the Present

Outspoken Skepticism concerning Many Traditional Beliefs

Widely Advertised Formulation of Steps Necessary for Man's Control of Nature

Growth of Rationalism

Development of Mathematics in Relation to Philosophy

Foundation of Theory of Probability, important as a Rationalistic Explanation of Many Complex Phenomena

Profound Changes in Theological and Philosophical Thought, Separation of Philosophy from Theology and Establishment of the Former upon a more Rationalistic Basis 
Within the period covered by the foregoing table the universe was literally made anew. For the primitive ideas regarding geography and astronomy, surviving since the dawn of history about the shores of the Mediterranean and essentially like those of savage peoples the world over, were cast aside. Only the establishment of the evolutionary theory during the nineteenth century can compare with the revolution in human thinking thus produced. But evolution made its way in a more tolerant age when freedom had been won and its story is less dramatic. As one writer says, "There came, one after the other, five of the greatest men our race has produced-Copernicus, Kepler, Galileo, Descartes, and Newton-and when their work was done the old theological conception of the Universe was gone. 'The spacious firmament on high'- 'the crystalline spheres'the Almighty enthroned upon 'the circle of the heavens,' and with his own hands, or with angels as his agents, keeping sun, moon and planets in motion for the benefit of the earth, opening and closing the 'windows of heaven,' letting down upon the earth the 'waters above the firmament,' setting his bow in the cloud, hanging out 'signs and wonders,' hurling comets, 'casting forth lightnings' to scare the wicked, and 'shaking the earth' in his wrath: all this had disappeared." 3 And with its disappearance came the knowledge of a new heaven and a new earth. Truth had begun to triumph over ignorance. An age of Science was replacing an age of Superstition.

\section{GROWTH OF SCIENTIFIC AND RATIONALISTIC KNOWLEDGE}

The appearance of individuals of genius and the occurrence of events of revolutionary import are indicative of the dawn of a new age. It was so with the Renaissance. The great Italian national poet, Dante Alighieri (1265-1321) is in

${ }^{3}$ White, A. D., "A History of the Warfare of Science with Theology," Vol. I, p. 15. 
many respects a medieval figure but in others he is of the Renaissance. His science and theology were those of Thomas Aquinas, but his independence of judgment, his conception of the worth of the individual, and his appreciation of beauty are signs of the awakening. The existence of a rising skepticism toward the traditional teachings is suggested by the language of orthodoxy throughout the later years of the thirteenth century. The most conspicuous example of an individual who is known to have questioned the accepted doctrines is Peter of Apono (1260-1316), a disciple of Averroes and influential in the promulgation of Averroism in Italy. He seems to have denied the existence of demons and of miracles, although his beliefs were tainted by astrological superstitions. In his old age he was imprisoned by the Church on the charge of magic and intercourse with spirits, but as he died before sentence was pronounced the inquisitors could only burn him in effigy. Like Roger Bacon he descended to posterity as one of the greatest magicians of the time. ${ }^{4}$

Francesco Petrarca or Petrarch (1304-1374) is fully representative of the early Renaissance. His humanism was that blending of the old and the new which is characteristic of modern thought. Although a literary man and in no sense a scientist, Petrarch exhibits a rebellion against the traditional authority and a critical attitude indicative of the scientific spirit. He well represents the state of mind that characterized the Renaissance before the period of constructive thought. Petrarch contributed to the advancement of science by denouncing the astrologers as charlatans and rogues. The medical men of the time he regarded as no better, but he forecast the way to a science of health and disease which was later exemplified in modern medicine and surgery. He ridiculed the pious beliefs regarding animals inherited from the Bestiaries as childish superstitions, and of no value to man. In common with all humanists or men of

$$
{ }^{4} \text { Lerky, loc. cit., Vol. I, p. } 103 .
$$


the new learning, he abhorred the teachings of scholasticism and scoffed at the authority of Aristotle. He was the first great figure in the valiant battle, waged against makebelieve and superstition, by the rationalists of the fourteenth, fifteenth, and sixteenth centuries.

Neither the reputation which is popularly attached to Giovanni Boccaccio (1313-1375), and others of the humanists who are known chiefly by the laxness, from a modern viewpoint, of their standards of morality, ${ }^{5}$ nor prejudice toward the classical requirements that have hitherto dominated western education should conceal the fact that these men occupy an important place in the transition from medieval to modern scientific thought. Humanism may have acted as a temporary check upon the development of interest in the natural sciences. But the study of ancient literature was the most important single factor in the liberation of the intellect. Humanism did yeoman service in the advancement of the critical frame of mind which was a necessary preliminary to the constructive rationalism of modern science. In view of their limited knowledge of facts, it is remarkable that the humanists wrought so well.

By the year 1450 the recovery of the ancient learning was almost complete and the essentially modern culture of the humanists was fast displacing the gloom of the Middle Ages. As we have seen, the first century of the Renaissance (1350-1450) was an age of increasing skepticism and negation while the positive and constructive activities of the period were later accomplishments. After 1450 the study of nature assumed increasing importance. Facts began to accumulate and men awoke to the obvious truths of natural science, so that rapid advances in scientific knowledge became possible.

More than any other individual Leonardo da Vinci (1452-

5 The significance of the literary work of Boccaccio is not to be estimated by the salaciousness of the Decameron, but on the basis that, in opposition to the asceticism of the medieval spirit, he "proclaimed the beauty of the world, the godliness of youth and strength and love, unterrified by hell, unappalled by the shadow of impending death." Symonds, J. A., "The Renaissance in Italy." 
1519) embodies the spirit of the period. Whether one man can ever again grasp the learning of his day as Leonardo did is doubtful, in view of the present extension of knowledge. But in any era such a man would exert widespread influence. Known mainly as an artist, he was preëminent also as a man of science, an architect, and an engineer. For us, his importance lies in his apprehension of the scientific method and in his unique personality. Of him it has been well said, "He was not a scholastic, and neither was he a blind follower of classical authority, as were many of the men of the Renaissance. To him, observation of nature and experiment were the only true methods of science. Knowledge of the ancient writers, useful as a starting point, could never be conclusive." He grasped the fundamental concept that true science begins with observation. "Those sciences are vain and full of errors, he tells us, which are not born from experience, the mother of all certainty, and which do not end with one clear experiment. Science gives certainty, and science gives power. Those who rely on practice without science are like sailors without rudder or compass." Could there be a clearer statement of the nature and value of science even in the twentieth century?

As indicative of his grasp of fundamentals in scientific method and fact, may be cited his understanding of the nature of fossils and of the changes by which mountains have been upraised, together with the effects of erosion. For example, he says that the Po will eventually lay dry land in the Adriatic as in the past it has deposited a great part of Lombardy. For Leonardo, nature was devoid of magic and subject to immutable necessity. If his fragmentary notes, apparently taken with a view to publication in encyclopædic form had become accessible, it is hard to tell what force they might not have exerted in the advancement of science. ${ }^{6}$ It is of interest, in view of his renown as an artist,

${ }^{6}$ Among many remarkable passages is the following upon the saltness of the sea. After considering various explanations notably those of Pliny, Leonardo 
that Leonardo's reputation in this field rests not alone upon his creation of a few great paintings but upon the fact that he possessed so wide a perception of the possibilities of this form of artistic expression. He has been characterized as "not so much a painter as a great inventor in painting." Corot, for example, proclaimed him, "The creator of modern landscape," although the landscape feature in Leonardo's paintings is seemingly an insignificant part. His attitude as an artist was rather that of the man of science than that of the traditional man of art. For him, reality and perfection were the same. This explains the seemingly incongruous union of the artist and the scientist. The list of the mechanical devices to which he devoted intensive study, is amazing in its extent and diversity. Some of the more interesting cases are the following: He was the real pioneer worker in aviation, as a science in which air currents, specific gravity, the flight of birds, and the like were studied, along with the production of a heavier-than-air flying-machine (Fig. 7). He seems to have made as much speculative and observational progress with the problem as was possible before the creation of modern machinery and the invention of internal combustion engines. He devised a variety of machine guns and other similar mechanisms, a machine for excavating

concludes "that the saltness of the sea is due to the numerous springs of water, which, in penetrating the earth, find the salt mines, and dissolving parts of these carry them away with them to the ocean and to the other seas, from whence they are never lifted by the clouds which produce the rivers. So the sea would be more salt in our times than it has ever been at any time previously; and if it were argued by the adversary that in an infinite course of time the sea would either become dried up or congealed into salt, to this I reply that the salt is restored to the earth by the setting free of the earth which is raised up together with the salt it has acquired, and the rivers restore it to the earth over which they flow." His arguments against the explanation of marine shells of fossil deposits as having been left by the Noachian deluge display a knowledge of geological fact and method which did not become common information until after the work of James Hutton toward the close of the eighteenth century. Numerous quotations from his scientific writings are easily accessible in the volume entitled: "Leonardo da Vinci's Note Books," by Edward McCurdy. See also: Wetham, loc. cit. 
canals, a large number of hydraulic devices, a smelting furnace, and so on through a list of unbelievable length. $\mathrm{He}$

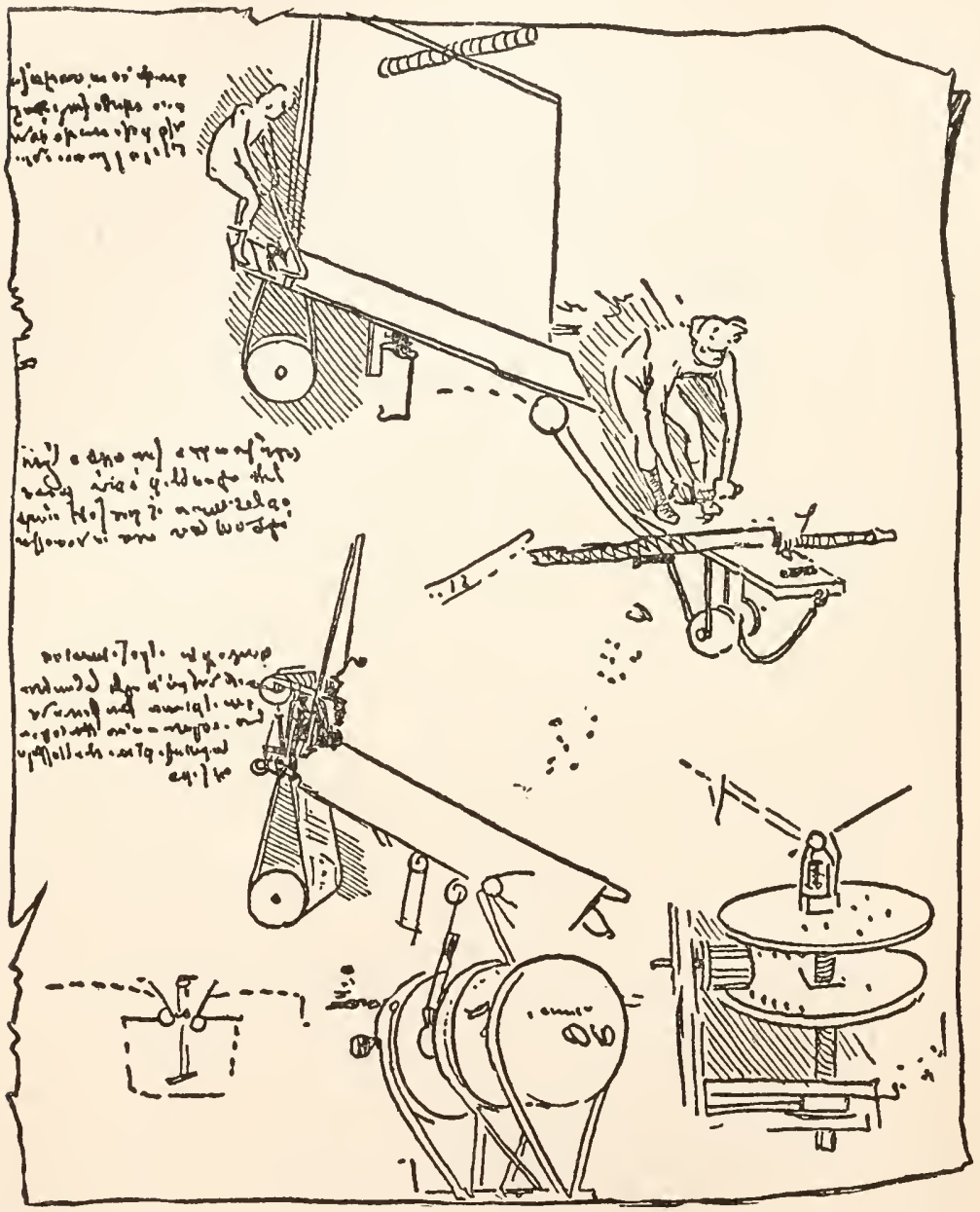

Fig. 7. Sketches Relating to Flying Machines. From the note books of Leonardo da Vinci. (Courtesy of Scientific American.)

forecast the coming of steam engines and steam navigation. He drew plans of model towns and cities and was thus the originator of the modern concept of the city beautiful. His 
manuscript notes describe a modern system of factory efficiency. More than any other individual who has lived, Leonardo seems the superman of human intelligence.

Leonardo was not entirely alone, although he is clearly

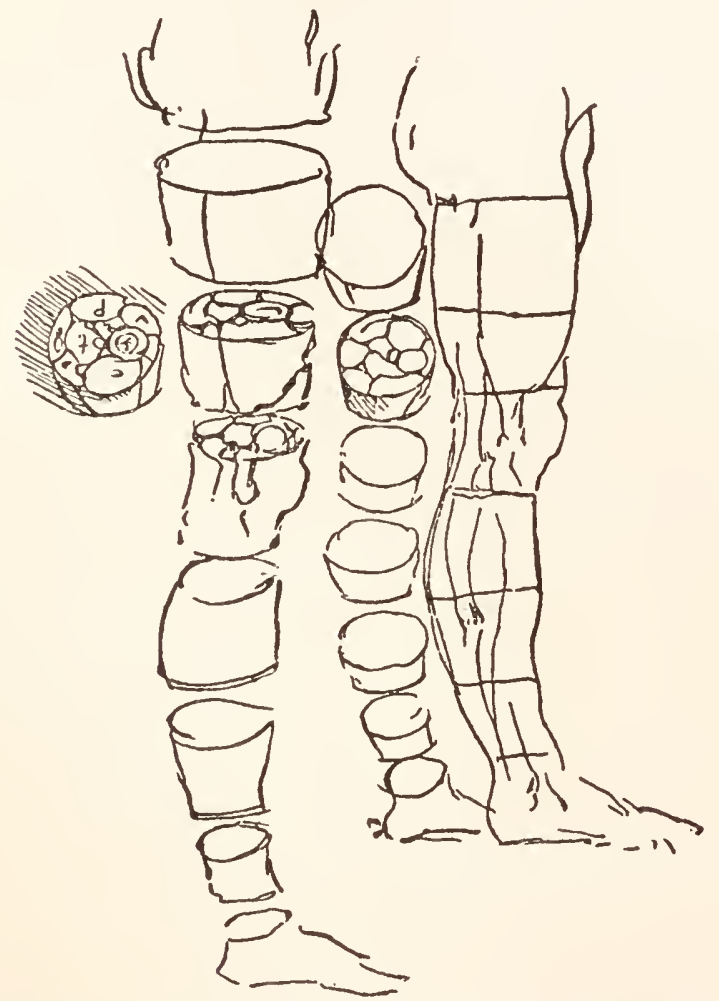

Fig. 8. Leonardo's use of Cross-Sections to illustrate Anatomy. From the note books of Leonardo da Vinci. (Reproduced from a Figure in Singer after Hopstock.)

the greatest among the men of genius developed by the Italian Renaissance. Giovani Pico della Mirandolla (14631494) possessed the most catholic view of learning and scholarship of any man of his time. His most important service to science was his refutation of astrology, which accomplished 
the final overthrow of this false view of astronomy. Leone Battista Alberti (1404-1472), an earlier contemporary, had for his motto "Men can do all things if they will." His interest in science together with his proficiency in physics and mathematics greatly aided the forward movement of enlightenment which so aroused his enthusiasm. Modern experimental science begins with Galileo in the sixteenth century. But the services of the humanists, and of the workers and thinkers from Peter of Apono to Leonardo da Vinci, were an essential part in the development from the supernaturalism, still dominant in the thirteenth century, to the established rationalism of sixteenth and seventeenth century science.

The scientific methods of observation and comparison were first applied by the Renaissance in the field of literary and historical criticism. They appear in Petrarch and others of the humanists who applied the principles of textual criticism to historical documents. ${ }^{7}$ This spirit of literary criticism was not without importance for the Reformation, although the later Protestant orthodoxy was not well disposed toward the extension of critical study. The publication of the work of Copernicus in 1543 was the climax in this development of observational and descriptive science. The older geo-centric theory of Ptolemy, promulgated in Alexandria during the second century of the Christian Era, had become an integral part of Christian theology. The Copernican system proposed what was literally a new universe. The story of the controversy which was thus precipitated is familiar to all. We have alluded to its significance in a previous section.

The Renaissance did more than extend the scientific methods of observation and comparison. Its claim to be the period in which modern science became established is based

${ }^{7}$ The case of Laurentius Valla may be cited in illustration. "At the request of King Alfonso of Naples he subjected the so-called Donation of Constantine to the tests of the new criticism and showed its historical impossibility to the conviction of the world, thus depriving the papacy of one source of argument in support of its pretensions." Adams, G. B., loc. cit. 
primarily upon the development of experimental and analytical methods. While the spirit and appreciation of science appear in da Vinci, the modern intensive attack appears first in the investigations of Galileo (1564-1642). Building upon the work of Copernicus, Galileo continued the advance in astronomy despite theological opposition. By the year 1700, Descartes (1596-1650) and Pascal (16231662), by establishing the theory of probability had eliminated evil spirits from many hitherto inexplicable phenomena on the earth, while Kepler (1571-1630) and Newton (1642-1727) had enthroned natural law in the heavens.

Geographical and astronomical science were established by the voyages of discovery, and by the scientific work of Copernicus and Galileo. Chemistry, which had existed as alchemy since the early Christian Era and which had been defined during the eleventh century as "the preparation of silver and gold," received an impetus through the chemical medicine of Paracelsus (1493-1541); while the foundation of modern chemistry was laid by Boyle (1627-1691) who defined chemistry as "the composition of substances," and emphasized the methods of experimentation and inductive reasoning. Boyle defined the elements as substances incapable of decomposition, and the compounds as substances composed of elements, but the development of this generalization was subsequently held in abeyance by the promulgation of the erroneous Phlogiston-Theory. ${ }^{8}$

Within the field of physical and mathematical sciences, Galileo had established the science of dynamics by his experiments with falling bodies. His laws of motion had made possible the explanation of the continuous movement of the planets, but their orbital movement remained unexplained. Newton applied to the heavens the simple, though even now inexplicable, phenomenon of gravitation; and calculated the sweep of the planets in the same terms as the fall of a stone. His emotional excitement during the conclusion of his cal${ }^{8}$ See: note, p. 97 of the present volume. 
culations is said to have been "so great that he could hardly" see his figures"; and certain it is that of all the generalizations of science none is more marvelous than the theoretical extension of the simple phenomena of motion and gravitation, observed on the surface of the earth, to the farthest star.

Mathematical science was keeping pace. Indeed the work above indicated would have been impossible at an earlier period, when methods of calculation were little developed. Space will not permit a further elaboration of the progress of science along these mathematical-physical lines during the period under discussion. We may emphasize, in conclusion, the growing significance of the philosophical aspects of mathematics and physics, in addition to their value as practical tools of science.

In the biological sciences, the Middle Ages had, as we have seen, produced little beyond a garbled and childish account of some of the ancient knowledge of Aristotle and Galen. Gradually the study of human anatomy by dissection became possible. In 1315, da Luzzi had published a manual of anatomy, based not upon Galen but upon actual dissection. Vesalius (1514-1564) now laid bare the secrets of the human frame and overthrew many traditional errors. Harvey (1578-1657) not only discovered the circulation of the blood but also established the experimental method which has since dominated the science of physiology. Botany was widely cultivated through the search for herbs of medicinal value. The first Botanical Gardens came into existence for the cultivation of rare and interesting plants. Stimulated by medical science and by the general awakening, the biological sciences were proceeding along two great lines: knowledge of the number and kinds of animals and plantsNatural History; and knowledge of minute structures and organisms-Microscopy. The microscope did not come into use as an instrument of biological investigation until the latter half of the seventeenth century, but the more general facts of microscopic structure, aside from the cell-theory, had 
been ascertained before the year 1700 . The bacteria, the protozoa, and a host of minute organisms were discovered by Swammerdam (1637-1680), Leeuwenhoek (1632-1723), and their contemporaries. Redi, in 1668, disproved spontaneous generation in macroscopic forms; but the mode of generation in the microörganisms was not entirely established until the nineteenth century. Malpighi (1628-1694) made known the facts of microscopic anatomy. ${ }^{9}$

A work which illustrates the transition from medieval to modern concepts in natural history is the "Puch der Nature" by Conrad von Megenberg. Although first printed in 1475 , this volume dates from an earlier period, for it was a German translation, with some changes, from the Latin "De Naturis Rerum" completed by Thomas of Cantimpré about 1248. It is, therefore, truly medieval but a great advance upon the Physiologus. The figures are crude, yet they give some internal evidence of having been drawn from nature and being specially prepared for the volume in question (Fig. 9). The popular interest in such works is attested by the fact that the volume passed through numerous editions and was followed by others which were the first crude beginnings of modern studies in natural history. Interest in first-hand knowledge of animals is thus evidenced during the later Middle Ages. ${ }^{10}$

The collection of animals and plants in zoölogical and botanical gardens further illustrates the advancing knowledge and interest in natural history. This custom originated in Italy with the increase of wealth and economic stability. Botanical gardens were attached to large estates and to public establishments. Collections of animals from foreign countries became popular among the wealthy. These not

${ }^{9}$ Further elaboration of these advances in the study of microscopic structures and microörganisms is omitted here, since the subject has been used as an illustration in a subsequent chapter. See: pp. 246-250 of the present volume.

${ }^{10}$ Locy, W. A., "The Earliest Printed Illustrations of Natural History," Scientific Monthly, Sept., 1921. 
only served the same purpose as the modern menageries and zoölogical gardens, by gratifying curiosity, but served also the higher purpose of observation and experiment. The im-

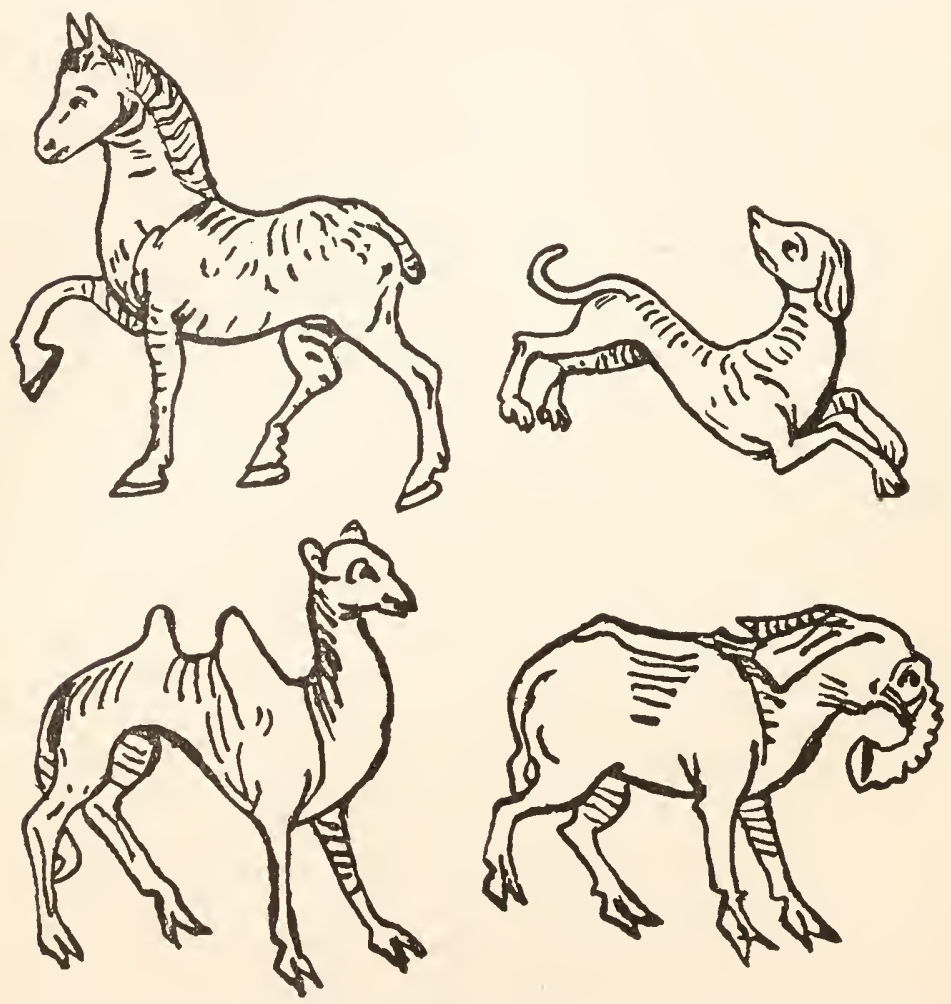

Fig. 9. Four Figures of Quadrupeds. Traced from a plate of twelve figures in "Das Puch der Nature" by von Megenberg. Although printed in 1475 and showing figures some of which bear internal evidence of having been drawn from nature, this work was based mainly upon the earlier manuscript and figures of the truly medieval volume "De Naturis Rerum" by Thomas Cantimpré about 1248. Contrast with the more accurate and artistic figure from Gesner (Fig. 10). (Reproduced from Locy, Scientific Monthly, Sept., 1921.)

portation of strange animals from distant regions was not difficult because of the geographical situation of the Italian peninsular and because the mild climate rendered possible the keeping of animals from warmer latitudes. Lions were 
especially numerous, because of their symbolic interest and because of the excellent way in which they stood captivity. They were used at times as executioners and their presence near the palace of an Italian tyrant had doubtless a measure of political and social effectiveness. A present of lion cubs is frequently mentioned in diplomatic documents. The city of Florence also kept leopards and other wild beasts, employing a special keeper.

By the close of the fifteenth century large menageries were in existence. Matarazzo, the chronicler of Perugia, tells us that: "It belongs to the position of the great to keep horses, dogs, falcons, and other birds, court jesters, singers and foreign animals." The point for our purpose is that the presence of elephants, giraffes, zebras and other strange animals helped to open men's minds to the wonders of animate nature and to acquaint them with the various sorts of animal life. True it is that no attempt was made to improve on the Aristotelian system of zoölogical classification, but at the same time a more rational and scientific attitude toward animal life developed. People no longer believed in the ridiculous myths and fables of the medieval bestiaries or natural history treatises. There are, moreover, interesting evidences of successful efforts towards scientific breeding and improvement of stock in connection with the stud of Francesco Gonzaga, duke of Mantua, and along this special line considerable advances were undoubtedly made. ${ }^{11}$

The Swiss, Conrad von Gesner (1516-1565), must have been aided in his studies on natural history by the existence of these zoölogical gardens. His great work, "Historia Animalium," is indicative of the decline of the medieval absurdities, and proved of great educational value in the popularizing of scientific facts concerning the larger animals (Fig. 10). But there was no immediate advance toward a more scientific classification, even with the work of Gesner. In contrast

${ }^{11}$ Burckhardt, J., loc. cit. The further account of an anthropological menagerie given by this author is of interest in this connection. 
to the dramatic discoveries attendant upon the advent of the microscope, the study of natural history was distinguished, during the seventeenth century, by the slow and laborious collection of facts regarding the number and kinds of animals

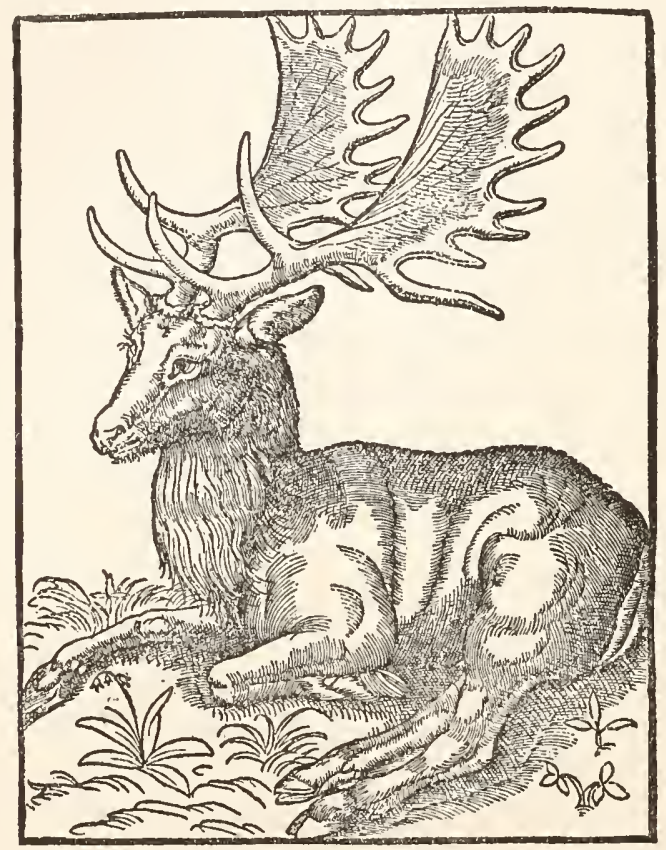

FIG. 10. Representative Illustration from Gesner. Photographic reproduction of one of the original woodcuts. (Reproduced from Brooks, Popular Science Monthly, May, 1895.)

and plants. Upon this foundation, John Ray (1628-1705) established the first exact concept of a species; and Linnæus, in the succeeding century, set forth the first universal classification.

The numerous societies and academies, which arose first in Italy and Southern France, are indicative of the intellectual activity of the period. The older universities were founded during the twelfth and early thirteenth centuries and hence were a product of scholasticism. To the early 
reformers of the Renaissance, the universities appeared as strongholds of the old order. They were, according to Petrarch, "nests of gloomy ignorance." Even later, the humanists were grudgingly received within the schools; and not infrequently, when the humanistic learning had been assimilated, it was rendered sterile by the erection of the ancient masters to a place of authority, not in harmony with the spirit that had developed with the advance of critical scholarship. Under these circumstances, the more independent spirits sought their inspiration in organizations outside the established intellectual institutions, where freedom of thought was unhampered. ${ }^{12}$ These early scientific societies were reproductions of similar organizations which had formerly existed among the Moors, in Grenada and Cordova. Some of them, like the Academy of Toulouse, founded in 1345, have survived to the present day. As the Renaissance spreads northward, the same tendency is apparent. The Royal Society of London was incorporated in 1662 and has survived through a long and illustrious career. In the beginning, it was accused of "destroying the established religion, of injuring the universities, and of upsetting ancient and solid learning." 13 Eventually, there was not a capital in Europe without these organizations which were thus independent of the formal educational system. Thus ended the isolation of the workers in science. Moreover, the academies gave the scientists a degree of solidarity, and encouraged all who opposed the traditional doctrines.

12 "The Accademia del Cimento, established at Florence, 1657, held its meetings in the ducal palace. It lasted ten years, and was then suppressed at the instance of the papal government; as an equivalent, the brother of the grand-duke was made a cardinal. It numbered many great men, such as Torricelli and Castelli, among its members. The condition of admission into it was an abjuration of all faith, and a resolution to inquire into the truth." Draper, J. W., "History of the Conflict between Religion and Science." p. 300.

${ }_{13}$ Draper, loc. cit., pp. 307-310. 
POSITION OF SCIENCE AS ESTABLISHED BY THE RENAISSANCE

In the foregoing sections, the scientific awakening of Europe has been traced from its beginnings in the later Middle Ages to its culmination during the sixteenth and seventeenth centuries. In such a complex of men and events it is difficult to keep in mind the larger changes. We shall, therefore, enumerate the broader features of this momentous step in human development by a brief characterization of particular periods. In this, one must remember that dates are arbitrary, that round numbers have no meaning as such, and that such an outline necessarily disregards the overlapping which is so important a factor in the growth of ideas. With these reservations, the intellectual development considered in the preceding pages may be summarized as follows:

750-800 Revival of the schools under Charlemagne.

Evidence of an abundance of intellectual ability.

800-1150 Failure of the schools, because of unstable political conditions.

Glimmerings of intellectual progress in isolated individuals.

Influence of the Arab science during this period.

1150-1200 Intense intellectual eagerness culminating in scholasticism.

1200-1300 The century of scholasticism-a great intellectual period, although its point of view was not in line with subsequent developments.

The dawn of European science is seen in the cumulative influence of the Arab science, and in the scientific insight and vision of Roger Bacon.

1300-1350 Disappearance in the progressive centers of Europe of the frame of mind most distinctive of the Middle Ages.

Growing skepticism regarding traditional authority.

1350-1450 Period of destructive criticism and growing rationalism which prepared the way for the constructive scientific work of the later Renaissance. 
1450-1500 Beginnings, in Italy, of the constructive period of the scientific Renaissance.

1500-1600 Rapid accumulation of facts and development of rationalistic explanations of natural phenomena.

1600-1700 Dawning concept of the rational explanation of all natural phenomena.

Not only were the broader facts of modern science made apparent by the workers of the Renaissance, but also the significance of science began to be appreciated in its relation to civilized life. What Roger Bacon had foreseen with prophetic vision, and what was beyond the comprehension of his contemporaries, his more superficial namesake, Francis Bacon (1561-1626), helped to establish in the popular imagination. While the latter was given too high a position, when he was called the father of the inductive sciences, he undoubtedly deserves the credit of giving publicity to the failure of the deductive scholastic reasoning and of having formulated, in such a manner as to secure its general acceptance, the claim that the scientific method possesses unbelievable possibilities. During the seventeenth century men began to be persuaded that there must be natural solutions to problems, although they were unable to discover them. And the fact that this attitude of mind has become almost an obsession in modern times illustrates better than almost anything else how far we have departed from the supernaturalism of the Middle Ages.

The Renaissance, taken as a whole, marks the intellectual awakening of the western world. If we have seemed to include too much under the head of Science in the Renaissance, it is not because we would claim all for science but because the manifestations of science are everywhere present. The Renaissance in its broadest meaning marks the beginning of modern culture. It was not alone the revival of the old it was also a creation of the new, first by the Italian people and later by the other western nations. The Protestant Reformation and the English and French Revolutions 
were the natural extensions of the scientific and rationalistic developments which had their beginnings in Italy during the fourteenth and fifteenth centuries. These religious and political revolutions were a contribution by the northern peoples to the larger movement. We must have in mind the whole social complex, material as well as intellectual, if we are to reach a proper evaluation of the Renaissance in relation to science and human affairs.

The two outstanding features of the period were the discovery of the human mind and the discovery of the world of nature. Knowledge of antiquity was important, because it helped the humanist to discover himself and to feel his kinship with the minds of other days; knowledge of nature, because it brought into being the modern scientific spirit. Once set in motion, these factors and many others became inextricably interwoven. In art, the human body was rediscovered as a thing of beauty, while nature lost its "taint of sin" and became again beautiful to the eyes of man. Having passed that painful period in which doubt is not yet regarded as innocent and having undergone the sufferings of suspended judgment, the human mind was liberated as from a dungeon during this wonderful intellectual outpouring that was, as Symonds puts it, "the first transcendent spring-tide of the modern world." A sense of human dignity appeared, different from anything in evidence during the Middle Ages and on an even higher level than the sense of human worth of ancient times. Excessive individualism and worldliness were vices of the period, but were not necessary adjuncts of the new and scientific humanism. The distinctive feature was not the recovery of the older arts and inventions nor the discovery of the new, but "the attainment of self-conscious freedom by the European peoples." In science, we may catalogue the specific discoveries of these centuries of the awakening, but the more important factor was the establishment of the modern scientific spirit. Freedom and self-consciousness found ex- 
pression in science; and the spirit thus generated continues, dominant throughout the western world. Not alone in science but in the whole sweep of our activities, we of the present are carrying forward that which the men of the Italian Renaissance began. 


\section{CHAPTER V}

\section{THE FURTHER GROWTH OF SCIENCE}

The year 1700 is chosen as the beginning of the modern scientific period, because the theoretical and practical applications of science began to be widely comprehended during the eighteenth century. Many important facts in astronomy, in geography, and even in biological science were, indeed, ascertained before this time. The scientific method was recognized by certain individuals. But the great extensions of detailed knowledge and appreciation of the meaning of many scientific facts had not taken place. By the middle of the eighteenth century scientific thinking had become emancipated from superstition and started on its own path of unprejudiced observation and experimentation.

During the latter half of the century there was rapid advancement in many lines. In the biological sciences, foundations were being laid for the later Cell-Theory, and the first definite statement of Organic Evolution was being promulgated; while comprehension of physiological processes was opening the way to a science of medicine. In astronomy and the physical sciences, the concept of a dynamic as opposed to a static universe came to be recognized as a scientific fact, and the theories of Conservation of Energy and of Chemical Combination began to assume definitive form. In the field now designated as that of political and social science, the secularization of many activities, the progress of individualism, of rationalism, and of toleration indicate a growing scientific temper. The attempts to apply scientific fact and method in the solution of larger social problems indicate the hold which science had obtained upon mankind by the close of this first century of 
modern scientific times. In the material applications of science, the later decades of the century witnessed the beginnings of the Industrial Revolution. The rise of modern industry and the rise of modern democracy were almost simultaneous. The scientific frame of mind developed during the Renaissance was mainly responsible for these momentous changes as well as for the technical progress of eighteenth century science.

\section{FOUNDATIONS OF THE MODERN SCIENCES}

The history of natural science during the seventeenth and the early eighteenth centuries is characterized by the rapid accumulation of minor facts. Just as the manifold details were added to the outline of geographical knowledge furnished by the earlier centuries of discovery, so astronomical and other branches of science became increasingly comprehensive. Biological knowledge, for instance, received an impetus during the latter half of the seventeenth century by the serious use of the microscope in scientific investigation. The discovery of microörganisms immediately followed, and the minute anatomy of larger forms was made known. In studies with the microscope, as well as in natural history, examination of new kinds of animals and plants presented seemingly endless fields for discovery. Hence the broader biological problems were commonly disregarded. Nevertheless, the generalizations of present-day biology were rooted in the detailed knowledge thus acquired. A similar situation existed in other scientific fields. The knowledge of scientific fact and method, then acquired by the popular mind, marks the beginning of a persistent inclination toward scientific explanations, which had far-reaching consequences even during the eighteenth century. ${ }^{1}$

${ }^{1}$ The dilletantism of many individuals, who posed as savants at this time, tends to obscure the situation which actually existed. The underlying stimulus to such pretensions among the upper classes was the position of unprecedented esteem in which scientific men were held. 
In geographical science, to cite further examples, the nature and extent of the earth had become known among the educated and traveled classes. This popular knowledge of geography did not, of course, lead to scientific generalizations, but proved influential along social and political lines. The peoples of western Europe became conscious of their position in the world and of the coexistence of other peoples in all the stages from barbarism to civilization. Foundations were being laid for a science of human society.

In astronomical science, the nature of the solar system had been ascertained by Copernicus and Galileo and the laws of motion and gravitation had been extended to the heavens by Newton. It remained to set forth the way in which the heavenly bodies had reached their present form. Cosmic Evolution, with its implication of a dynamic universe, found definite expression in the Nebular Hypothesis of Laplace (1796). ${ }^{2}$ By this hypothesis, the laws of mass and motion, as applied by Newton to the present solar system, were extended to the past. The existing system was conceived as having reached its present state through the action of natural forces. The nebular hypothesis is not the only theory, of the origin of solar systems, maintained by astronomers at the present day. But the idea of our own and other solar systems as having undelgone evolutionary modification, is to-day the accepted historical generalization of astronomy. Laplace and his associates among the French Encyclopædists believed they were on the threshold of an explanation of the universe in terms of matter and motion. If their generalizations were premature, they were nevertheless in agreement with the explanations since established by science. The concept of cosmic evolution, which the nebular hypothesis implies, is now accepted as a matter of course.

${ }^{2}$ The prevailing statement that the Nebular Hypothesis originated with Kant seems to be incorrect. Lovejoy, A. O., "Kant and Evolution," Popular Scientific Monthly, Dec., 1910. 
Again, the later years of the eighteenth century were important in the history of chemistry and physics. Such generalizations as the Atomic Theory, and the theories of Chemical Combination, Conservation of Energy, and Indestructibility of Matter were at least tentatively established. When the nature of elements, compounds, and solutions became sufficiently clear, chemistry could progress. When the distinction between matter and energy was recognized, the great advance made by physical science during the nineteenth century became possible. ${ }^{3}$

The development of the atomic theory is an example of how the theories of science may have their beginnings and may reach their existing limits in philosophical speculation. The doctrine that matter consists of invisible and indivisible particles between which is a void appears in Hindu philosophy at a remote period. Among the Greco-Roman philosophers, Democritus and Lucretius were its ardent exponents. During the Middle Ages theological beliefs sufficed. In the seventeenth century Boyle and also Newton recognized its advantages. The former had even grasped the idea of permanent elements and changeable compounds, and had defined chemistry as "the composition of substances." But the Phlogiston-Theory intervened. ${ }^{4}$

${ }^{3}$ These generalizations have persisted as the foundations of modern physicochemical theory, although the structure and possible divisibility of the atom is a subject of present-day investigation. The facts discovered in connection with radium have made the chemist skeptical regarding the permanency of unchanging elements. The theory of the conservation of energy is, of course, based upon experimentation within limited fields. Nevertheless, these fundamental hypotheses, which made their appearance toward the close of the eighteenth century, have constituted the point of departure for subsequent physico-chemical investigation.

${ }^{4}$ Robert Boyle $(1627-1691)$ stated the principle that only tangible and ponderable substances should be recognized as elements, a chemical element being a substance from which other substances could be made. Georg Stahl (1600-1734) developed the Phlogiston-Theory. Phlogiston was "the principle of combustion," and was considered as a definite body and hence material. All chemical action was explained as due to the presence of this all-important substance. This concept delayed the establishment of the atomic theory, but 
The advance of biological science during the century under discussion was mainly important as a preparation. The Cell-Theory was not formulated until the second quarter of the nineteenth centuly. Organic Evolution was not generally accepted until the publication of Darwin's "Origin of Species" (1859). The development of biological science during the closing centuries of the Renaissance has already been summarized. During the eighteenth century, the facts regarding the number and kinds of animals and plants were organized by Linnæus (1707-1778). His was the first system of classification which pretended to an arrangement of all the known forms of life. If Linnæus did not originate the binomial nomenclature, ${ }^{5}$ by which each kind of animal is given a double name, he may be said to have established its use. His general scheme, of species, genera, and families exists at the present day, despite the progressive changes in the larger groupings and the wholly new concept of classification which was necessitated by the doctrine of evolution. Linnæus introduced order into the study of animal life, and

it was a good theory for the time being and did not hamper chemical progress in many lines. It was finally overthrown when Lavoisier (1743-1794) showed, by means of the balance, that combustion was a process and not a substance, since it possessed no weight. The way was then open for the establishment of the atomic theory through the work of Dalton (1808). At the present time physicists speak of the structure of the atom, of the continuous ether, and of all matter as energy, and even challenge the philosophers with interesting theories of ultimate reality. But despite modifications, the atomic theory with its concept of relatively indivisible atoms, which combine into molecules, is the working assumption of physico-chemical science. The atoms and the void, now called the ether, have never been seen. Belief in their existence, despite the fact that it explains visible phenomena, is a theoretical generalization which is useful because it gives a summary basis for the explanation of tangible facts.

${ }^{5}$ Here, as elsewhere, use of a second or even a third name had been made as a matter of course. It now became universal in biological science. Its value lies in the fact that the naming can be more definite the greater the number of names applied. But more than two is cumbersome. Thus we speak of the Smiths, and to be specific, of John Smith; going further, of John Henry Smith: just as we designate the cats, Felis, and the domestic cat, Felis domestica. 
though he is not known to have favored the evolutionary theories promulgated during his lifetime, he made an important contribution in this direction by so classifying plants and animals that men could visualize the resemblances and differences now explained in terms of evolution.

The discussion of a generalization so important as the theory of organic evolution must be deferred. For the purpose here, it is only necessary to state that the doctrine of descent with modification was first promulgated in scientific terms by Buffon (1707-1788) and his contemporaries. It is important, in considering the eighteenth century as a period during which the larger generalizations of modern science were being formed, that the theory of evolution was then proposed upon a scientific basis. Many significant facts in anatomy, embryology, heredity, and variation, had been established. Attention was directed to the close anatomical resemblance between man and the apes. Moreover, evolution or the Theory of Transmutation, as it was then called, was openly and widely discussed in intellectual circles. ${ }^{6}$ This early attempt to formulate organic evolution in terms of science culminated in the Lamarckian theories during the first quarter of the nineteenth century. The temporary failure of the evolutionary hypothesis was due to insufficient knowledge and to prejudice in favor of an explanation of organic nature in terms of the Biblical account of creation. The Transmutationists of the later eighteenth century were expressing the spirit of their day when they attempted to organize the facts of biological science into a fundamental theory of the origin and development of all living things.

The phrase origin of life may be used in a twofold sense. It may refer either to the origin of the species (evolution) or to the origin of the individual. The latter problem appears in the eighteenth century controversies over the theory of

${ }^{6}$ Lovejoy, A. O., "Some Eighteenth Century Evolutionists," Popular Science Monthly, July, 1901. 
Spontaneous Generation. This theory, although restricted to the origin of microscopic organisms, was actively championed. Redi had show (1668) that insect larvæ, which had been supposed to arise spontaneously in decaying flesh, actually arose from the eggs of parent forms, as did larger animals like the birds and reptiles whose eggs are of conspicuous size. It was, of course, recognized that the higher plants developed from seeds. The discovery of microörganisms (c. 1675) reopened a question which might otherwise have been regarded as settled. Admitting that larger animals and plants arose from parents, and not by a process of spontaneous generation, it might still be maintained that simpler and microscopic types originated without the intervention of living matter. The early investigators beheld their infusions teeming with microscopic organisms that appeared literally over night. Some naturally believed there could be no other explanation of this sudden appearance but that of spontaneous generation. Although the work of Spallanzani (1775) and others during the eighteenth century produced evidence against this spontaneous origin of living bodies, it was impossible to secure a conclusive verdict until the cell-theory was established and until complete life-cycles for representative microscopic forms were made known toward the middle of the nineteenth century. The later eighteenth century was concerned with this problem, as it was with the broader generalizations in other scientific lines. In view of the absence of a cell-theory, it is perhaps remarkable that the advocates of spontaneous generation were not more numerous.

In medicine, the final steps, which divorced the treatment of disease from superstitions such as belief in demoniacal possession and in the visitations of Providence, were taken during the eighteenth century. This happened in spite of popular survivals of such beliefs. Disease was increasingly acknowledged to be an abnormal bodily state, and as such to be subject to investigation by science. Jenner's discovery of 
vaccination against smallpox (1796) was the precursor of the vaccinations of the present time. The Germ-Theory of disease was forecast by the increasing emphasis upon the analogy between the spread of disease and the spread of living organisms. But the generalizations, which ushered in the existing science of medicine, were made possible only by further extensions of biological knowledge in the early nineteenth century.

Other examples might be cited. The foregoing suffice to show that the great generalizations in the older sciences began to assume their present form during the eighteenth century. Some of these, like the theory of the transmutation of species, were unable to maintain themselves. Acceptance was delayed until a later time. In other cases, such as the cell-theory, the eighteenth century failed to discover the thread of common meaning. Yet to a surprising degree the men of this early modern period arrived at generalizations that were points of departure for scientific progress during the century which followed.

In brief, the larger regions of science were mapped and charted, and the scientific method was acknowledged as the correct procedure within the realm of nature. There was still confusion over what constituted natural knowledge. Important fields, such as the mental phenomena since claimed by the psychologists, were excluded from the scientific domain. But even to-day non-scientific explanations are offered for phenomena which may eventually be explained in terms of science. Toward the close of the century the distinction between science and philosophy attained wider recognition; while supernaturalism began to receive its present valuation. It should again be emphasized that any separation between the Scientific Renaissance and modern times is arbitrary, for since the days of Leonardo and Galileo science has gone forward with increasing momentum. 


\section{APPLICATIONS OF SCIENCE TO MODERN INDUSTRY}

The value of science in modern industry, commerce, and agriculture is so generally appreciated that any lengthy discussion is quite unnecessary. Exploitation of nature by means of scientific knowledge is the most conspicuous feature in the history of civilization during the past two hundred years. Since the middle of the eighteenth century, the western world has undergone almost as complete a metamorphosis as it did in the thousand years during which the Teutonic barbarians were changed into the civilized peoples of the Renaissance. The steps in this profound reorganization, which has produced a culture based upon science, must be considered, if we would understand the place of any particular science in the twentieth century.

In the past, commercial intercourse has brought exchange of ideas as well as goods; and as a result, civilizations have been made anew. Ideas, like diseases, follow the routes of trade. The Phenœcians were the earliest common carriers of the world; through them the influence of the Egyptian and of the Mesopotamian cultures was extended along the shores of the Mediterranean until it quickened western Europe. Later, the commerce of Greece was the initial impulse to the establishment of Greek colonies in Sicily and southern Italy and to the westward spread of Hellenic civilization. During the Medieval Period, commerce with the countries about the eastern end of the Mediterranean was an important factor in preserving the tradition of an ancient learning commensurate with the majestic ruins of the Roman world which Europe beheld in Italy, France, and Spain. We have referred earlier to the development of an industrial aristocracy, founded upon the trade of the Italian cities with the Orient, and its relation to the intellectual awakening of the Renaissance. The Mediterranean was the great trade-route of the world before the geographical discoveries of the fifteenth and sixteenth centuries. Until the 
opening of the Modern Period, the Near East was the principal source of ideas, as well as the finer products of industry, both of which were transmitted mainly by following established routes of trade.

The discovery of a broader world by the Portuguese and Spanish navigators was the first step in the commercial supremacy of western Europe. The Mediterranean became insignificant, as a means of communication with the East, upon the discovery of the sea-route to India and upon the domination by the Turks of the caravan routes from the Red Sea and Persian Gulf. The wealth of the western hemisphere and of the Orient tempted both merchant and adventurer. And thus the Europeanization of the world, which has been characterized as "one of the most fateful events of all history," was set in motion. Dissemination of knowledge concerning the world and its peoples has been rightly regarded as one of the major influences in the broadening of the mental horizon that was distinctive of the Renaissance. Much of this dissemination was due to the intercourse of commerce and to the increased wealth and leisure which was thus brought to western nations.

While Arab civilization and later the Revival of Learning were leavening the mind of Europe, the trade of the Italian cities was producing a more tolerant and matter-of-fact spirit which was further developed by the centuries of discovery. Contact with peoples beyond the European pale, even though they were regarded as inferior to Christians, showed that Christendom contained the lesser portion of the human race. Innovations became more easy when new and strange customs had been observed elsewhere. The pirateadventurers, who harried the Spanish Main and brought home booty to Elizabethan England, laid the foundation for the extension of English trade and colonization in India and America during the century which followed. But more than this, they opened the way for new ideas. Knowledge of the new geography was brought to Europe mainly as the 
result of commercial activities. What the Mediterranean was, in the dissemination of culture during ancient times, the "Seven Seas" became during the transition from the Renaissance to the Modern Period. The Industrial Revolution, which began in England about the middle of the eighteenth century, was a natural sequence to the development of trade during the period between 1600 and 1750 . The modern appreciation of scientific knowledge in relation to practical life was an inevitable product of the Industrial Revolution.

Thus the relation of commercial intercourse to the advancement of science was at first incidental. Under the liberalizing influence of trade, new ideas were able to take root. The leisure incident to increasing wealth gave opportunity for intellectual development. Even with the advent of the Factory System, the influence upon scientific progress was still indirect. Only in the nineteenth century did industry grow conscious of its dependence upon scientific knowledge and thus become the most effective means of making widely known the facts and methods of science.

Modern industry arose in England during the latter half of the eighteenth century. The replacement of hand labor by steam and water-power, together with the development of a remarkable series of practical inventions, gave rise to the Factory System and to the industrial expansion of the modern era. It may be observed that these first steps in the direction of scientific industry were taken by men of practical bent, who were, in the main, ignorant of scientific theory. It was found immensely profitable to manufacture for exportation, and under this impetus the initial steps of industrial development were quickly taken. The medieval dislike of innovation having been removed, the practical Englishman entered upon his period of industrial supremacy to be checked only toward the close of the nineteenth century by the growth of more scientific methods among his later commercial rivals. 
Water-power, which had come into general use in England after 1770 , was gradually replaced by steam. The crude steam engine, invented by Savery (1698) and improved by Newcomen (1707), was used for pumping water from mines as early as the first decade of the eighteenth century. But although this steam pump doubled the depth at which coal could be mined, steam power was not feasible for general purposes until after the invention of the first real steam engine by James Watt (1769). ${ }^{7}$ In the cloth-making industries, Kay's flying shuttle (1733) and Hargreave's spinning jenny (1764) revolutionized weaving. Arkwright's so-called water-frame (1769) was an improvement upon the spinning jenny. Compton combined the jenny and the water-frame in his mule or muslin-wheel (1779), and Cartwright's powerloom (1785) increased the demand for power and powerdriven machines. The history of weaving is duplicated in many lines of manufactory. Invention followed invention in rapid succession. Improvements in the iron industry made easier the construction of machinery. Commerce demanded better means of transportation. Bridges, breakwaters, and dams became common. Road building progressed rapidly, and canal building linked together the growing industrial centers, enabling cities like Manchester and Liverpool to attain an unprecedented prosperity. The steamboat (1807) and the steam locomotive (1825) were the final triumphs of steam as applied to industrial and commercial activities. ${ }^{8}$

This Industrial Revolution began in England during the later eighteenth century. Early in the following century

${ }^{7} \mathrm{~A}$ machine, which revolved by means of steam on the same principle as the modern turbine, is recorded as having been produced by Hero of Alexandria about 130 в. с. But this earliest recorded steam engine, like another machine invented by Hero and driven by the expansive power of heated air, was used only for trivial purposes. Ewing, J. A., Ene. Brit., Article on "Steam Engine." $C f$. p. 35 of the present volume.

${ }^{8}$ Tickner, F. W., "A Social and Industrial History of England," Chap. XXXVI. 
it spread throughout western Europe and to the New World. Not only were all the old lines of industry remade, but wholly new industries were created just as in our own times. This involved a complete social reorganization, the effects of which have extended to the present day and the adjustment to which is not yet complete. There are also many points of interest in the revolution in methods of agriculture which proceeded side by side with that of industry. This was stimulated both by the increasing urban populations, with their demands for food, and by the corresponding reduction of the available farm labor. As is the case with the industrial situation, betterment of agricultural methods and the social adjustments entailed by excessive urbanization are problems which have continued to the twentieth century. Viewing the entire situation, two features are in evidence: The Industrial Revolution has proceeded with unbroken continuity from its beginning in the eighteenth century; and this revolution was initiated almost exclusively by practical inventors, who harnessed the forces of nature that they might secure wealth for themselves. The eighteenth century was not lacking in men who understood the visions of Roger Bacon, of Leonardo, and of Francis Bacon, each of whom had foreseen the possibilities in man's control over nature. But it was reserved for the nineteenth century to develop an appreciation of scientific theory in relation to industry. So long as the relatively easy and simple things remained undone, the inventor was the dominant figure. He still retains his place in the adaptation of established principles to new combinations of circumstances. But the situation at the present day has become vastly more complicated.

The material progress of the nineteenth century, based upon this harnessing of the forces of nature, is a familiar story. The steam engine came to perform the labor of millions of men and made possible a production, and hence a consumption, of goods which was previously inconceivable. 
By its application to transportation, steam made distance insignificant and thus increased the content of individual experience. The possibility of better living conditions was created, although in the rush for luxuries the sum total of human toil may not have been lessened. A similar revolutionary advance, is occurring in the present generation, through the medium of the electric generator and the gas engine. The bearing of this material progress upon the ultimate welfare of humanity, and the disastrous effects of these human activities upon the exhaustible resources of our planet need not be considered here. Practical men believe this kind of advancement worth while, and the desire for physical comforts, is likely to countenance the exploitation of nature so long as it continues easy and profitable.

Material progress during the past one hundred and fifty years has been founded upon a progressive control of the forces of physical nature. This control has been made possible by the knowledge of nature called science. Assuming that our ant-like activities are worth while, the question is no longer whether this practical side of scientific knowledge is to be desired, but whether progress in those branches of science which are not obviously utilitarian is necessary for human welfare. Whether pure science as well as applied science is a necessity rather than a luxury. This question is being answered for the mass of mankind by the researches in pure science, which are becoming increasingly significant in connection with industry and agriculture. Commercial enterprise finds itself confronted with problems which are beyond the powers of the inventor of an earlier generation and which can be solved only by trained scientists. The technical investigator in the industrial research establishment is confronted with problems in abstract science which formerly exhibited no seeming relation to practical life. The same situation obtains in institutions established for the investigation of practical problems in agriculture. It is becoming a commonplace to say that the nation which does 
not base its industry and its agriculture upon an advancing knowledge of science is doomed.

The sublime confidence in the knowledge of the practical man, which distinguished British and also American industry throughout the nineteenth century, was doubtless bred of the fact that practical, self-made men were mainly instrumental in giving England, and later America, their initial positions as industrial nations. It was German scientists and German industrial laboratories, more than German commercial aptitude that challenged British supremacy in world-trade during the closing decades of the nineteenth century. There is a oneness, to scientific knowledge, which makes the distinction between the practical and the theoretical of no avail, and this fact is gradually becoming acknowledged even among hardheaded men of affairs. In the future, new industries are likely to be created by advances in pure science, such as the discovery of radio-activity or of new methods of electrical transmission, rather than by rule-ofthumb inventions.

Thus, the outstanding feature of modern industrial progress has been the control of nature by means of scientific knowledge. This was and is the general formula for the material prosperity of western nations. In the physical sciences, we have reached a point where this formula is patent to all thinking men, who recognize that the evolution of mechanical devices and of industry begins and ends with scientific knowledge. There has even grown up a popular faith that inventors, like Edison and Marconi, who for the man in the street are the great scientists, can accomplish anything if given time. This belief may not be warranted, but the material progress effected through science during the recent centuries has been so continuous that such a belief is not unnatural.

The western world has developed a culture that is obsessed with the idea of science as an instrument of material progress, because the practical and theoretical phases of 
scientific knowledge have so impressed the occidental mind. We shall not dwell at greater length upon this aspect of modern science nor describe its material achievements of civilization, save as they explain the manner in which the scientific habit of mind has assumed its present eminence. Science has won recognition by its material accomplishment in matters of everyday life, and hence the scientific spirit has appeared in places where it would not otherwise have come into being. For this reason, the history of industry and of common labor is second only to the history of knowledge in an understanding of the relation of science to the affairs of men.

\section{INFLUENCES AND IMPLICATIONS OF SCIENCE}

The more general and indirect effects of science during the eighteenth century may now be considered. Among other evidences of the influence of scientific knowledge, was the rapid decline of the spirit of persecution that occurred in Europe during the seventeenth century. Men had long been taught that credulity was a virtue and doubt a sin. The new learning enforced the doctrine that belief must rest upon evidence that was open to examination. To persecute successfully, one must be sure he has the truth. What science implies is not so much the importance of any particular truth as the right to seek truth and extend it unhampered by restrictions. Particular beliefs can survive only so long as they justify themselves against opposition. It is the essence of the spirit of persecution to be unfair and to assume that the doctrines of the persecutors need no justification. The scientific advances of the Renaissance set up standards of thinking which made persecution no part of righteousness. The spirit of intolerance did not disappear, but it became increasingly difficult to justify such a spirit upon grounds of morality.

Waning belief in the material efficacy of supernatural 
agencies was another outcome of scientific knowledge. Men came to assume that natural explanations must exist even in cases where none had been discovered. The concept of natural law gradually replaced that of supernatural interference. The decline in the sense of the miraculous, which is so distinctive a feature of modern times, had set in during the sixteenth century. Many old beliefs had perished by indifference, and the secularization of intellectual activity was much in evidence even before the seventeenth century. The Italian genius had borne the brunt of the initial advance from the intellectual servitude of an earlier period. But a succession of wars and disasters, during which the Church of Rome set itself against intellectual progress and Italy became the battle ground of nations, together with the malign influences of the Counter Reformation, won the day. The intellectual emancipation of Europe, through the development of a scientific spirit, was thenceforth carried forward by the northern and western nations.

We have seen that, with the decline of the ancient learning, philosophical thinking became merely an adjunct to the dominant theology and that this situation culminated in the scholastic philosophy of Thomas Aquinas. The story of the emancipation from this intellectual bondage is the history of the rise of modern rationalism and of the implications drawn from the facts of modern science. The larger movements proceeded somewhat as follows: The Reformation, despite its intolerance, emphasized the value of individual opinion. Rationalistic tendencies were much in evidence during the seventeenth century, as shown by the contentions of the protestant clergy in their conflict with Rome and by the philosophy of Descartes. The Deists of the late seventeenth and early eighteenth century in England were not a powerful company intellectually, and their attempt to formulate a natural religion gained scant recognition; but they were a sign of the times. The more significant fact is the extent to which their essential doctrines 
gradually permeated the thought of orthodoxy. In England, for example, there existed during the eighteenth century a surprising amount of rationalism, as an outcome of the tacit acceptance of deistic teachings. ${ }^{9}$ Despite a pathetic lack of knowledge concerning many details of scientific fact, eighteenth century thinkers perceived the implications of science to an extent for which mankind is even now scarce prepared. As a result, rationalistic systems of thinking established their right to existence.

But if science has been important in the foundation of modern philosophy, the rôle of the philosopher and of the man of letters has been no less significant in the extension of science. The scientist is often unmindful of the broader significance and of the popular acceptance of scientific doctrines. The philosopher, on the other hand, is interested in the implications of science and frequently extends these implications to fields where science is not established, but where popular interest may be acute. Science advances through the general acceptance of its teaching as much as by additions to knowledge. The thinker, who pursues its implications and who induces others to follow his lead, is no less important in scientific progress than he who contributes to the establishment of technical generalizations.

The importance of Francis Bacon (1561-1626) is due mainly to his understanding of the implications of science. Although dethroned from the place he long occupied as father of the science of physics and of inductive philosophy, Bacon deserves a prominent position, because he apprehended, at an early period, the steps by which man might cease to be the plaything of blind forces and become the controller of his environment. In his attempt to "extend more widely the power and greatness of man," Bacon gave publicity to the concept of man's relation to nature which has since become the creed of science. He did not originate

${ }^{9}$ Stephen, Leslie, "History of English Thought in the Eighteenth Century." 
this concept, for Roger Bacon and Leonardo were before him. But more than any man of his day he gave impetus to the doctrine that in science rests the progress of the future. ${ }^{10}$

What Francis Bacon accomplished in the popular mind René Descartes (1596-1650) accomplished in philosophical thought. The full significance of the scientific discoveries of the Renaissance would have remained unappreciated, had it not been for the extension of the method of science which was begun by Descartes. The scholastic system of thought was doomed by the discovery of scientific facts, but it was not overthrown until it could be replaced by a system based upon the new knowledge. Descartes produced the first great philosophy which was independent of scholastic tradition and in agreement with the science of the period. More than any other he may be regarded as the founder of modern philosophical thinking; since he gave the necessary impetus to the scientific method by his insistence upon the subjection of every opinion to critical examination. The Cartesian doubt is nothing more than scientific skepticism regarding traditional assumptions. The mechanistic conception of nature, which Descartes set forth as the necessary condition of scientific study, is the underlying assumption of all modern investigation in the exact sciences. ${ }^{11}$

The critical examination by John Locke (1632-1704) of the limits of the human understanding was a further step in the development of a scientific philosophy. It was also the forerunner of eighteenth century thinking as exemplified by David Hume (1711-1776) and Immanuel Kant

10 This belief has since been often and clearly stated. Among recent writers, it is vividly set forth by E. Ray Lankester, in the opening chapter of a volume entitled: "The Kingdom of Man," where, under the heading "Nature's Insurgent Son," man is pictured as an insurgent who has rebelled against nature and gone so far in his rebellion there can be no turning back.

${ }^{11}$ An excellent summary of the nature and significance of the thought of Descartes may be found in the familiar essay by T. H. Huxley, entitled: "On Descartes' Discourse touching the method of using one's reason rightly and of seeking scientific truth," Vol. I, "Collected Essays." 
(1724-1804). Descartes, Locke, Hume, and Kant were largely responsible for the replacing of the scholastic system by forms of thought compatible with scientific knowledge. In the course of this change in philosophical theory, the facts of science became permanently established as the starting point in the analysis of objective phenomena; while the critical methods of science were applied by the philosopher within the subjective field. Science gave philosophy a suitable point of departure for its speculations concerning ultimate reality, while philosophy extended and gave more concrete form to the methods of science.

But philosophical theories of reality and of the nature of knowledge are not so obviously important for mankind as the philosophical interpretations of everyday affairs, although we may believe that it is the activity of the great philosophical intellects which in the long run stimulates every real advancement. The line of thought which leads through Montaigne, Descartes, Bayle, and Voltaire is more immediately significant in its influence, because the thought of these writers so quickly pervaded the literature of the period. Montaigne (1533-1592) was the first popular representative of secular and rationalistic thought among the northern races. Skepticism regarding prevailing beliefs, which had developed toward the close of the Italian Renaissance, is further exemplified by his writings. He "ventured to judge all questions by a secular standard, by the light of common sense, and by the measure of probability which is furnished by daily experience." 12 In other words, he accepted the method of science. His essays upon the individuals and the society of his day emphasized the harmlessness of error in contrast with the evils of persecution, in a manner characteristic of the scientific temper. The growing acceptance of this point of view prepared the way for the ideas of Descartes, who recognized doubt as the beginning of wisdom.

${ }^{12}$ Lecky, W. E. H., "History of Rationalism in Europe," Vol. I, p. 112. 
The volume by Bayle (1647-1706), entitled "Compel them to Enter in," shows that its author began with skepticism and proceeded from thence to toleration. Intellectual liberty was Bayle's passion, and his critical examination of existing beliefs was an important step in the initial establishment of modern rationalism. The spirit of toleration which flamed forth in the writings of Voltaire (1694-1778) was the natural culmination of this trend of thought. It has been remarked that Voltaire's genius lay in the fact that he said what everyone thought at the time. If eighteenth century toleration condoned many excesses and proved a cloak for immorality, it was none the less a welcome change from the spirit of persecution which had prevailed. Individualism had freer play, and the spread of a truthful spirit outweighed the license which was often the first expression of growing liberalism. The spirit which appeared in literature is, therefore, an example of the implications drawn from scientific knowledge and brought to a focus by their application to the affairs of common life. Montaigne, Descartes, Bayle, and Voltaire exemplified and extended the scientific spirit, in that they warred against prejudice and encouraged mankind to examine the foundations of belief.

In regard to the broader influence of science, the eighteenth century, therefore, marks the final transition from the Renaissance to our own times. The philosophical import of scientific fact and method began to assume its present importance. What may be termed the implications of science assumed definitive form. Science for the first time attained self-consciousness and self-determination. During the eighteenth century men began to realize that the scientific point of view could be extended beyond the boundaries of what had been called the natural world. The political, economic, and theological fields of thought were subjected to scientific examination, if not to exact analysis. Science began to exer't a profound influence upon the thought of 
mankind, although the relationship between science and the changing frame of mind was not always appreciated. The pursuit of these implications has been greatly extended during the last hundred years. Their first general extensions occurred during the eighteenth century.

In this regard, the eighteenth century closed in failure. The first half of the nineteenth century was, in many respects, stagnant and negative. Technically speaking, science was making rapid progress, but its implications were not comprehended, in what were regarded as non-scientific fields. Mankind may never again witness such confident predictions of an approaching Age of Reason as were made during the later eighteenth century. The world may seem to have been living ever since in a period of retrogression. Yet science has done its work, and no future period of reaction can bring back the habits of thought that existed before the culmination of the Renaissance in this first century of the Modern Period. 

PART II

THE SCIENCE OF BIOLOGY 



\section{CHAPTER VI}

\section{THE BIOLOGICAL SCIENCE OF THE MODERN PERIOD: THE CELL-DOCTRINE}

Having outlined the historical significance of science in general and of biological science in particular, representative features of modern biology may now be considered. In common with all branches of science, modern biological science is more significant in human affairs through its influence upon the point of view than for its material achievements. Biology touches human life at so many angles that it is particularly adapted to illustrate the place now occupied by science in general within the lives of men. The biological sciences occupy a position intermediate between the sciences of inanimate matter and the less exact social sciences that deal with human behavior. An exhaustive survey of the biological field will not be atteinpted, but rather an outline of its broader features by means of concrete illustrations.

The development of biological science ${ }^{1}$ during modern times has been so diversified that we are first impressed

${ }^{1}$ The term biologieal science may be used broadly to include all fields of knowledge which are mainly concerned with the activities of living bodies whether of unicellular organisms or of men. In the more restricted sense, however, the term includes zoölogy, botany, the medical, agricultural, and similar sciences which depend most directly upon a knowledge of animals and plants. In the present chapter the term is used in its restricted meaning unless otherwise explained. Classification of science is, of course, arbitrary. There are no sharp distinctions in nature such as have come to exist within our minds. The same physical and chemical changes are found within the living body as in non-living matter. But since the phenomena of life still seem unique in many respects, we may, for convenience, make the broad distinction between the Physical Sciences, such as Chemistry, Physics, Astronomy, and the like, and the Biological Sciences, such as Botany, Zoölogy, Medicine, Agriculture, and their subdivisions. The Social Sciences might be placed in a third category, although, biologically speaking, they may be regarded as a form of Animal Behavior. 
by the coming into existence of a host of new sciences having little in common. But looking closer, these multitudinous developments may all be correlated with one or the other of two major hypotheses- the Theory of Organic Evolution and the Theory of Cells. Such sciences as Pathology, Bacteriology, Histology, Taxonomy, Ecology, and the like, may not have arisen in conscious correlation with either of the major theories. But having arrived, they arrange themselves quite naturally in relation to the broader generalizations. Pathology is the problem of abnormalities in cells, Taxonomy the problem of classifying animals and plants according to their evolutionary affinities. The others can be similarly aligned. Moreover, the general biological problems, distinctive of recent progress, allow of the same classification. Questions regarding the origin of living substance find their answers in the cells. The nature of vital processes, whether mechanistic or vitalistic, is a cell problem. The fundamental identity of vital phenomena is explained by the essentially identical structure and functioning of cells in all animals and plants. The nature of embryological development, the mechanism of heredity, the relation of living and lifeless matter, in short, the answers to "all ultimate biological problems must, in the last analysis, be sought in the cell." Its structures and activities give clues to the riddles of living matter. ${ }^{2}$ The theory of organic evolution is no less inclusive. The progress of modern biology is summarized by the story of these two greatest of biological generalizations.

\section{THE CELL-THEORY IN ZOÖLOGY}

The doctrine termed the Cell-Theory postulates that the living substance exists, almost without exception, in the form of microscopic units known as cells. This cellular structure was discovered in plants by the microscopists of the ${ }^{2}$ Wilson, E. B., "The Cell in Development and Inheritance," p. 1. 
seventeenth century. Hooke, Lecuwenhoek, Grew, and Malpighi recorded the presence of cells without recognizing them as universal. The simplest organisms, which consist of but a single cell, were studied for more than a century and a half before their cellular nature was recognized. Cells and their nuclei were described in many plants and in a few animals, during the first third of the nineteenth century. But it was not until 1838 that a cell-theory was promulgated for the animal body by Theodor Schwann, and, in the following year, for the plant body by Matthias Schleiden. The value of this generalization was at once apparent. It unified and explained observations of the most diverse sort throughout organic nature, giving an explanation, first, of microscopic structure and, second, of embryological development.

Since its universal acceptance toward the middle of the nineteenth century, the theory has found confirmation in whatever direction the microscope has been turned. The cell is now recognized as the unit of structure, and so of function, throughout the organic world. The problems of embryology, of physiology, of pathology, and even of heredity are, in the last analysis, cell problems. The domain of cellular biology has steadily expanded, until there exists an apparently inexhaustible field of investigation in cell chemistry and physics, as well as the structural features, which remain unexplored.

Cells were originally observed in the form of walled compartments, to which the term cell was fittingly applied. It was soon realized, however, that the walls, which had seemed the important feature, were not universal. The earlier concept of a series of minute cavities was displaced before the middle of the nineteenth century by the discovery that the protoplasm, or semi-fluid material enclosed within the wall, and not the wall itself, constituted the living stuff. Moreover, it was found that the walls, particularly in animal cells, were frequently represented by membranes so delicate as to seem non-existent. A "mass of protoplasm containing a 
nucleus" came to be recognized as the fundamental unit, and the inappropriateness of calling such a body a cell was acknowledged (Fig. 11). But the word had become so firmly established in terminology, that it has successfully

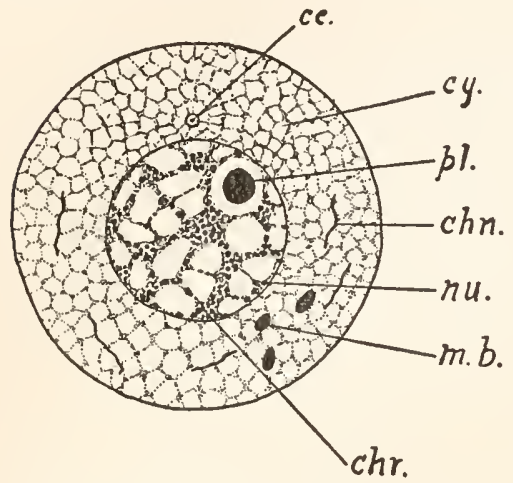

Fig. 11. Diagrammatic Figure of a Cell.

$\mathrm{Ce}$, centrosome; $\operatorname{chn}$, chondriosome; $c h r$, chromatin; $m b$, metaplasmic body; $n u$, nucleus; $p l$, plasmosome; $c y$, cytoplasm.

resisted both earlier and later efforts directed toward the substitution of a more suitable term.

The idea of animal and plant bodies being made of many independent, but at the same time interdependent, units, known as cells, thus came into existence. The simplest organisms were found to be composed of single cells. In general it was established that cells, like the bricks of a wall, make up the whole living structure. It was evident, therefore, that cell activities, collectively or individually, formed the basis for the activities of any living organism. All functions of organisms were seen to be cell functions in the ultimate analysis. Such a generalization laid new foundations for biological science.

As the universality of cells became apparent, their mode of origin was recognized as a problem demanding solution. The formulators of the cell-theory had supposed that cells arose by differentiation from a formative substance. Within a few years it was proved that cells arise only from preexisting cells by a process of cell division. Later, it was discovered that nucleus arises from nucleus in a similar manner. Following this, it was shown, that ovum and spermatozoön are merely specialized cells. Finally, it was ascertained (1875) that fertilization consists in the union of a single 
spermatozoön with a single ovum, and, more important still, in the union of nucleus with nucleus. The continuity between generations was thus proved to be a continuity of cells.

The foregoing facts constitute the foundation for the modern concept of development. The material basis of ontogeny, and so of heredity, is cellular. All present theories of differentiation, growth, heredity, and the like, rest upon the broader hypothesis of cellular organization. Like the evolutionary theory, the cell-theory became at once a great unifying generalization. The biologist recognized the cells, not only as units of structure and function in the existing organism, but as a key to the past. The living substance was revealed as a continuous, never-dying stuff, which could be traced back through many cell divisions to egg and spermatozoön, and thence to preceding generations. These facts led to the inference that the protoplasm had persisted through an infinitude of cell divisions since its first cell organization in the remote past. Thus it consists of the mortal body-cells, which constitute the adult bodies existing at any given moment, and of the potentially immortal ova and spermatozoa. The origin and nature of these germcells, their union in fertilization, and the processes of cell division and differentiation by which the adult organism arises from the single cell formed by their union, are all parts of the cell-theory as developed during the last fifty years. Cellular phenomena will probably remain an outstanding feature of the developmental process for all time.

The establishment of a cellular continuity between successive generations was a final blow to the recurrent theory of spontaneous generation. The results obtained by Spallanzani (1777), by Franz Schultze (1836), and later by Schwann and others, who found that life came only from preexisting life, were for the first time fully explained. It was shown that the living substance was composed exclusively of cells and that it arose solely by division of antecedent 
cells. The fact that living organisms arise only from parent organisms was explained, when the bodies of animals and plants were shown to consist of living cells which arose by cell division. The inherent falsity of spontaneous generation was thus shown as the cell-theory became extended to the entire field of development.
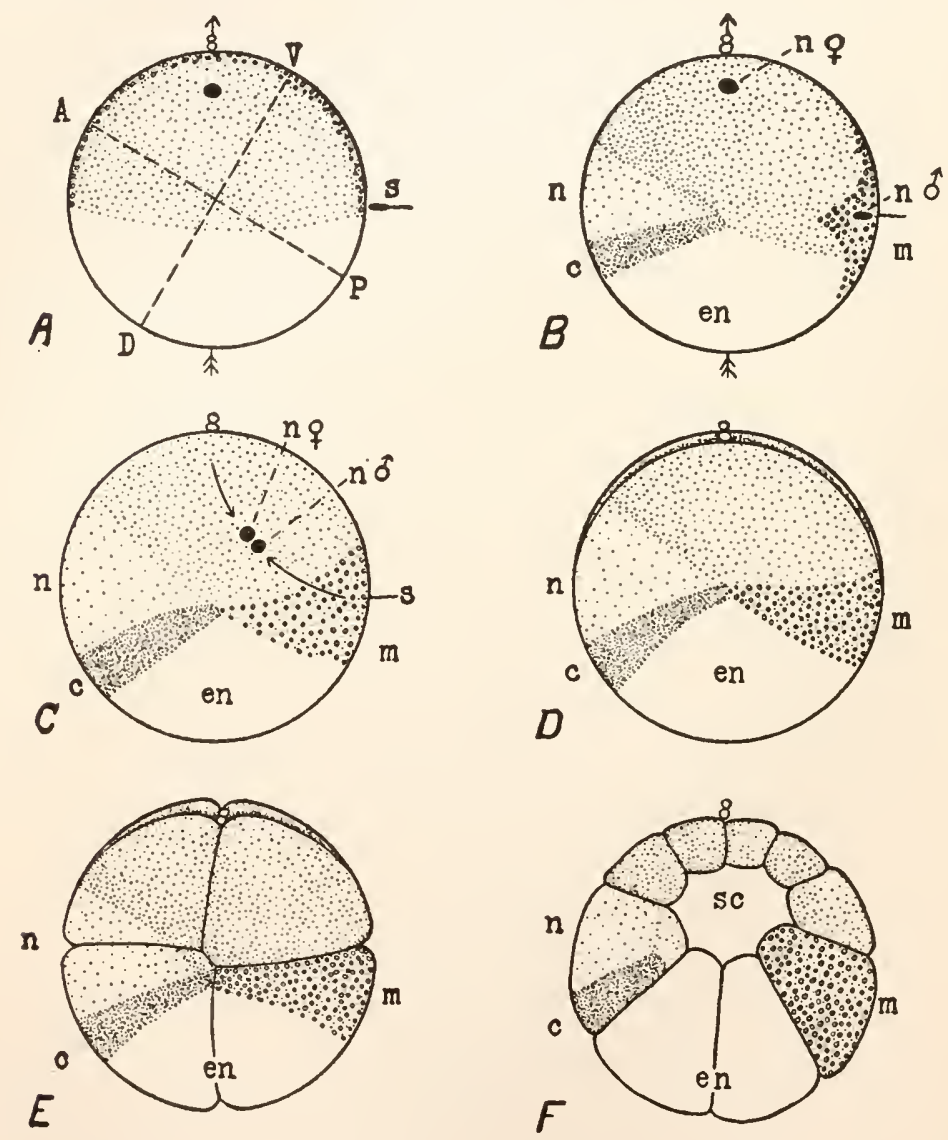

FIG. 12. Development of the Frog. Showing probable relations of axes of egg to axes of adult body. $A$, the egg or ovum at time of fertilization by spermatozoön (s); $B$, entrance of sperm; $C$, differentiation of certain portions of adult body (c, en, n, and $\mathrm{m}$ ), and approach of male and female nuclei; $D$, two cell stage; $E$, eight cell stage, $F$, early blastula; $G$, early 

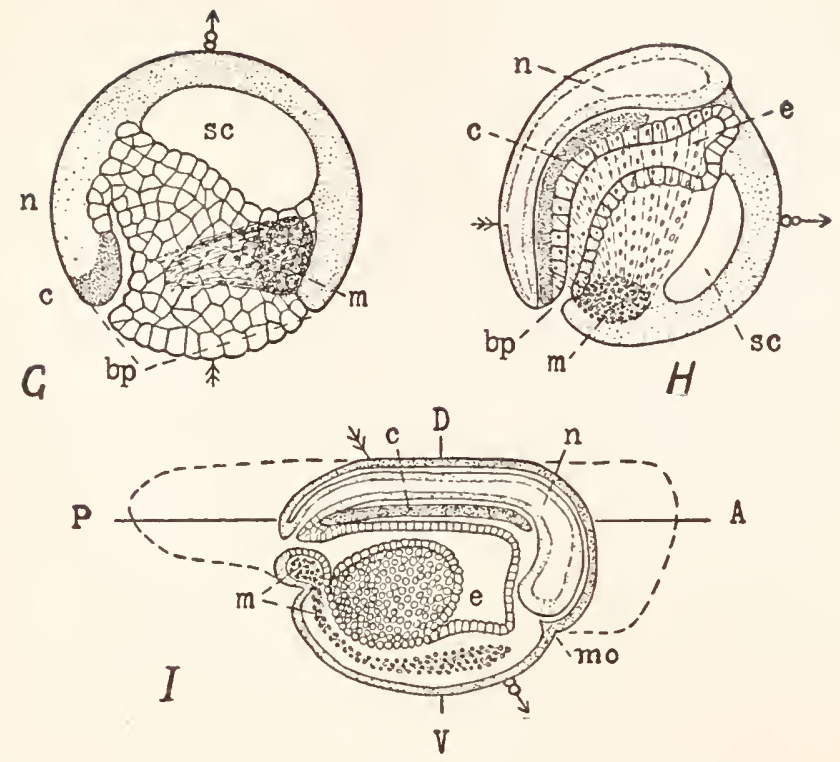

gastrula; $H$, early embryo; $I$, late embryo with dotted outline of an early tadpole stage. The arrow passing through the vertical axis and polar bodies of the egg in $A$ and $B$ is drawn in same position with reference to parts of egg and embryo in $G, H$, and $I$. The poles of the unfertilizerl egg ean thus be traced to regions of the embryo and thence to the adult. $\mathrm{A}$ and $\mathrm{P}, \mathrm{D}$ and $\mathrm{V}$, in $A$ and $I$ show the anterior-posterior and dorso-ventral areas appearing in egg and tadpole respectively. Note rotation of egg axis which occurs in stages represented by $H$, bringing dorsal surface to its definitive position in $I . B p$, blastopore (opening to primitive gut eavity); $c$, notochord (primitive backbone); $e$, enteron (gut cavity); $e n$, endoderm (lining of gut eavity); $m$, mesoderm; mo, mouth; $n$, nervous system; $n$ o and $n$ \&, male and female pronuclei of oösperm; $s$, spermatozoön (nucleus entering egg, flagellum remaining outside); $s c$, segmentation or blastula cavity. (Redrawn with modifications from Conklin, "Heredity and Environment.")

During the last fifty years, the cellular basis of development and hence of heredity has been ascertained in marvelous detail. The adult features of animals have been traced back to their origin in a few cells or even in single cells. The egg-cell has been studied before and after fertilization; and the cell-lineage of the adult parts has been made known. In the frog, for example, the unfertilized egg ex- 
hibits no foreshadowing of the adult body (Fig. $12 \mathrm{~A}$ ). When, however, the spermatozoön has entered (in this instance the entrance occurs at some point on the equator) differentiation begins. Stimulated by the entrance of the sperm, the protoplasm changes its appearance to such a degree that the axes and certain regions of the adult body can now be recognized (Fig. $12 \mathrm{~B}$ ). Portions of the egg which later form the anterior, posterior, dorsal, and ventral areas, are discernible and may be referred to the earlier stage (Fig. $12 \mathrm{~A}$ ). Areas from which are to be formed the nervous system (n), primitive backbone (c), and germ-layers of the early embryo appear within the egg, even before the male and female nuclei have completed their union. Thus, before any division of the egg-cell has occurred the general regions of the adult body have been delineated (Fig. $12 \mathrm{~A}-\mathrm{I}$ ). The cell divisions which ensue parcel out these predestined regions to groups of cells which develop into the adult parts. In some cases a few cells or portions of cells represent for the time being an entire organ or group of organs (Fig. $12 \mathrm{E}$ and $\mathrm{F}$ ). But this is not remarkable since the original fertilized egg-cell or oösperm represents the entire adult body. What is of interest for the present illustration is that the steps from single-celled oösperm to many-celled adult have been followed with such completeness. The cellular continuity between generations is known to these finest details. Embryological problems have, therefore, been reduced to cell problems.

But analysis of the cellular basis of development, and thus of heredity, has been extended to structures and activities within the individual cell. The basal fact of development is that the many-celled adult arises from a single cell formed by the union of ovum and spermatozoön. These germ-cells are the most wonderful of cells, because of their potentialities. They are, as it were, vehicles of inheritance, by which the characteristics of one generation pass to another. Naturally enough, their structure and mode of origin has 
been searchingly examined. The question has been asked whether any one portion of the germ-cell is more important than another. The answer is surprisingly definite. The material composing the nucleus rather than the cytoplasm seems the primary agency in development (Fig. 11). And within the nucleoplasm a stainable substance, the chromatin, is the more important. In the intervals between cell divisions the chromatin appears to exist in the form of stainable granules. But with the onset of cell division it takes the form of definite bodies, the chromosomes (Fig. 13 B, C, D). Although the chromosomes have been traced through the non-dividing period in only a few instances, there are theoretical reasons for believing that their individual existence is always preserved during these intervals when they cannot be readily recognized as chromosomes (Fig. $13 \mathrm{~A}$ and F). Chromatin, at least, persists and from it chromosomes are formed at every period of division. What is termed the Chromosome Theory of heredity has been developed, because the behavior of the chromosomes is correlated with end results in inheritance.

The more general evidence, which points to the chromosomes as the bearers of the heritage, can be appreciated upon brief explanation. When fully matured, the male and female germ-cells are very dissimilar in appearance. The ovum is, save for the presence of non-living food material called yolk, a very typical cell (Fig. $12 \mathrm{~A}$ ). The spermatozoön on the other hand is a most atypical cell (Fig. 14 A, $\mathrm{B}$, and $\mathrm{D})$. It consists of a mass of condensed nuclear material, almost wholly chromatin, and a relatively small amount of cytoplasm. At the time of fertilization, the socalled head and the middle-piece of the spermatozoön enter the egg, while the tail or flagellum usually remains on the outside playing no further part in development (Fig. 12 $\mathrm{B}$ and $\mathrm{C})$. While the middle-piece almost invariably enters the ovum along with the head or nucleus, this seems unnecessary even where it normally occurs. The essential 

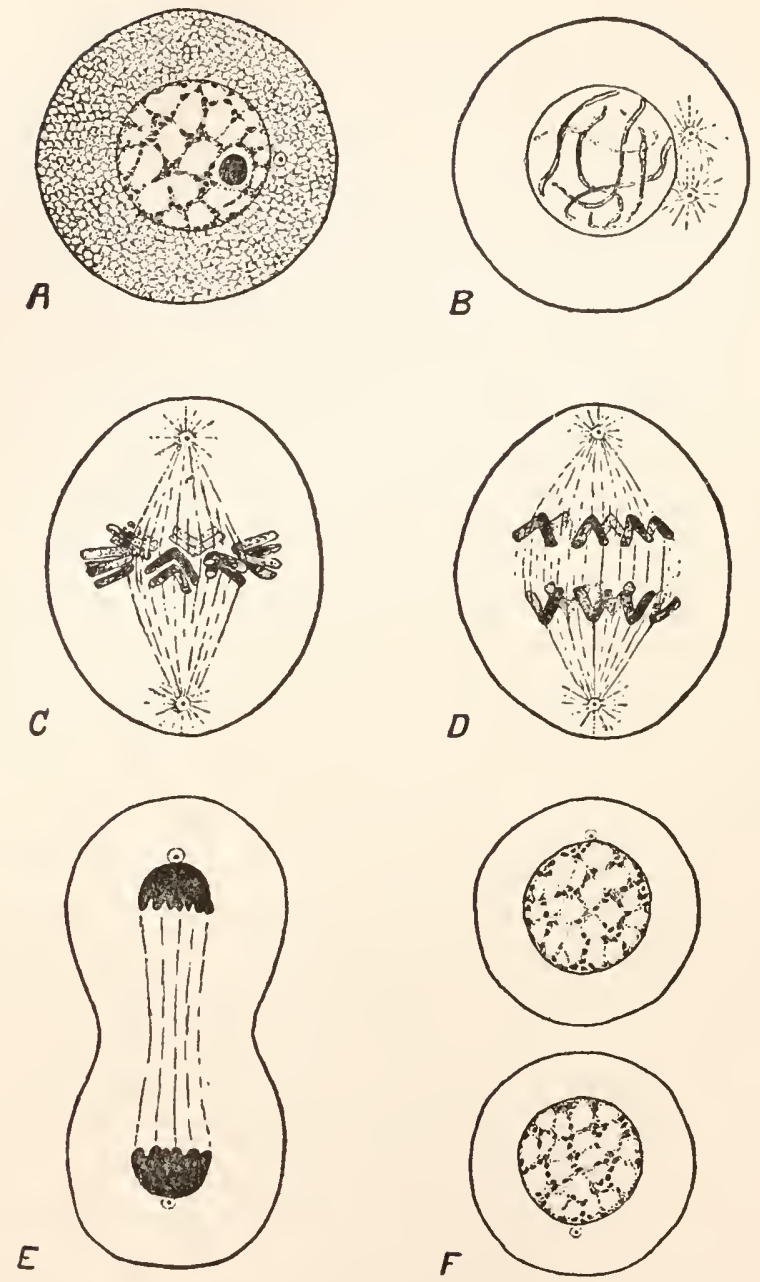

Fig. 13. Mitotic or Indirect Cell Division. $A$, cell with nucleus in resting phase; $B$, prophase, chromosomes appearing and two centrosomes that have arisen by division of the single centrosome in $A$ now separating with formation of spindle; $C$, metaphase, chromosomes at equator of fully developed spindle are now split lengthwise; $D$, anaphase, the separation of the two daughter groups of chromosomes; $E$, telophase, massing of two daughter groups and division of the cytoplasm; $F$, completion of the process with return of nucleus to resting phase. (Redrawn with modifications from figures by Agar, "Cytology.") 


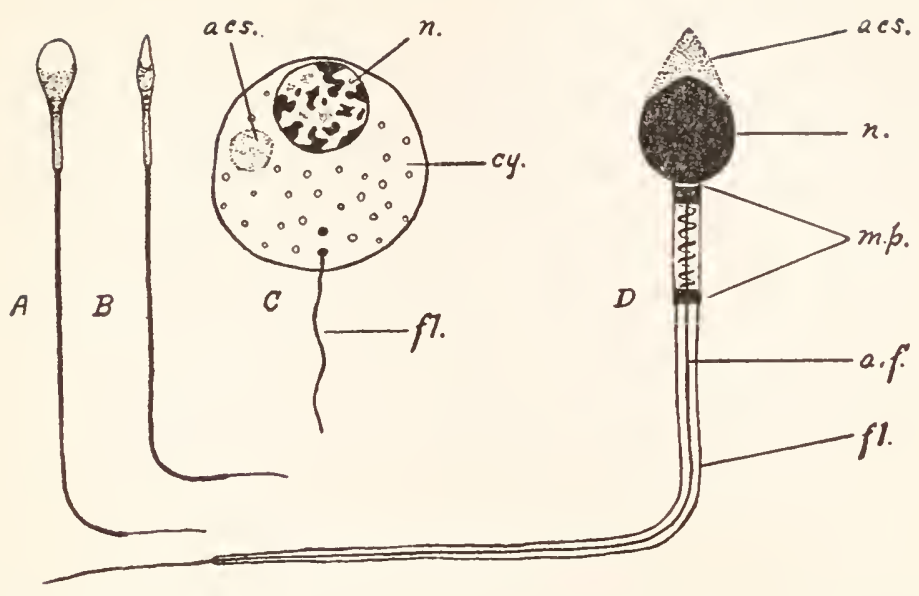

FIG. 14. Spermatozoa. $A$ and $B$, human spermatozoön, two views showing flattening of head (nucleus); $C$, stage in development of spermatozoön of guinea-pig, showing what is more obviously a cell; $D$, diagrammatic figure of fully formed spermatozoön of guinea-pig. Acs, acrosome; $a f$., axial filament; $c y$, cytoplasm; $f$, flagellum, $n$, nucleus; $m$. $p$., middle piece. ( $A$ and $B$ after Retzius; $C$ and $D$ redrawn from Agar after Meves.)

item in fertilization is the entrance of a sperm-nucleus and its union with the nucleus of the ovum.

At first glance the nuclei of ovum and spermatozoön appear disproportionate in size. When, however, the stages of the sperm-cells within the testis (Fig. 14 C) are studied, it appears that the chromatin of the spermatozoön is both quantitatively and qualitatively equivalent to the chromatin of the ovum of the same species. ${ }^{3}$ When the primitive male cells are made into definitive spermatozoa, their nuclei become more condensed, but their actual chromatin content remains the same (Fig. $14 \mathrm{C}$ and $\mathrm{D}$ ). This conclusion is further supported by the fact that the nucleus of the spermatozoön increases in size after entering the egg, so that before union the male and female pronuclei are again seen

${ }^{3}$ The only exceptions to this appear to be the cases where the chromosome formulas of the ovum and spermatozoön differ because of the presence of the sex-determining chromosomes which oceur in certain species. See: page 204 of the present volume. 
to be quantitatively and qualitatively equivalent. Fig. $12 \mathrm{~A}, \mathrm{~B}$, and $\mathrm{C}$ is diagrammatic in this particular.

It thus appears that the oösperm, from which the adult organism arises by cell division (Fig. 12), is composed of
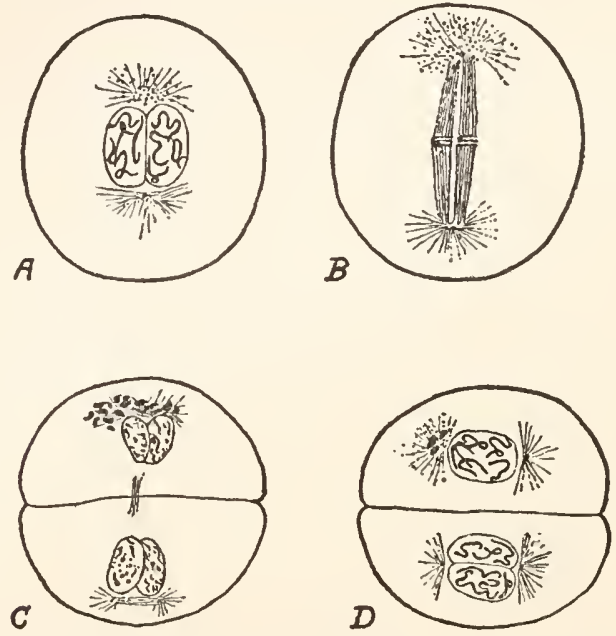

Fig. 15. Male and Female Pronuclei in Oösperm and Early Cleavage. $A$, oösperm at beginning of first cleavage showing the male and female pronuclei; $B$, metaphase of same; $C$, telophase; $D$, the two cell stage with one cell still showing a double nucleus. (Redrawn from figures by Agar after Amma.)

equal amounts of chromatin derived from the two parents, but of a very disproportionate amount of cytoplasm. If the latter were important as the vehicle by which the potentialities of the adult are carried over, we should expect an animal to inherit a disproportionate number of its adult features from the female parent. This is not the case. In general, the inherited features appearing in the adult are equally balanced. We therefore suspect that the chromatin which is the material within the germ-cells that comes in equal quantities from the two sexes is the basis of heredity.

A further word of explanation may be given regarding the 
chromosomes. These bodies appear at the time of cell division in definite number and, with certain exceptions, in pairs (Fig. 13). The number is as definite a characteristic of a species as five fingers or toes or any other feature which is numerically constant. The pairing is very clear in cases

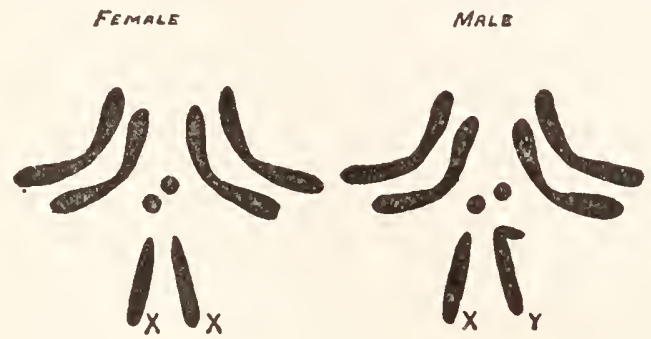

Frg. 16. Chromosomes of Drosophila. Diagrammatic representation of the male and female groups. Note that the chromosomes are in pairs, three of which would be readily distinguishable if the entire eight chromosomes were irregularly arranged. The pairs marked $X X$ and $X Y$ are the sex chromosomes. The hook on the $Y$ is a convention. (Redrawn from a figure by Morgan, et al.).

where the chromosomes are of different sizes and shapes (Fig. 16). Doubling of the number is prevented, at the time of fertilization, by the fact that in the final stages of the ripening ovum and spermatozoön the number of chromosomes is reduced one-half. Only one member of each pair of chromosomes goes to a germ-cell. When sperm-nucleus unites with egg-nucleus, the full number of chromosomes is restored and also the pairs. The oösperm is thus like all the later products of its division. When it passes into the two, four, eight, and sixteen cell stages, and so to the adult, the chromosomes divide with every cell division (Fig. 13). Each cell of the adult body possesses a nucleus whose chromosomes have descended, through a long series of cell divisions, from the nucleus of the one cell stage. This originated by a union of equivalent chromosomes from egg 
and spermatozoön. The pairing of chromosomes in all the cells of the body (Fig. 16) is thus explained by the bisexual origin of the chromosomes.

When we look at some part of an animal's body it sometimes seems to exhibit a mosaic of characters, seemingly inherited from both parents. In the human hand, for example, the shape of the fingers, the texture of skin, the pigmentation are, let us say, those of the mother. The nails, hairiness, and double-jointed thumb are those of the father. The biological conclusion is that such mosaics of features constituting adult bodies have been inherited in approximately equal numbers from the two parents. This is the external fact that we see in human beings and in the animals within a breeding pen. There could hardly be a more precise basis for such an equal inheritance of macroscopic features than the microscopic chromosomes, within every cell of the body and descended equally from the two parents.

Evidence for the chromosome-theory is even more detailed. In the fruit fly Drosophila, which has been the object of more extended studies in heredity than any other animal, there are four pairs of chromosomes (Fig. 16). The breeding results show four groups of heritable qualities, which go together in inheritance save for certain exceptions that do not vitiate the chromosome-theory. These groupings or linkages are shown in the accompanying table. It happens that the size of the chromosomes in the four pairs (Fig. 16) roughly parallels the size of the four groups of heritable characters as thus far discovered. This may not be significant, but one suspects that the small group of linked characters is borne by the small pair and the large group by one of the large pairs of chromosomes. In view of all the facts, the chromosomes appear to be the most important factor in heredity. Through them, rather than through the cytoplasm, the hereditary constitution seems to be transferred from one generation to the next. 
GROUPS OF CHARACTERS LINKED TOGETHER IN INHERITANCE IN THE FRUIT FLY, DROSOPHILA AMPELOPIILA. Each of the terms listed below is a characterization of a heritable peculiarity. (After Morgan et al., "Mcchanism of Mendelian Heredity.")

\begin{tabular}{|c|c|c|c|}
\hline Group I & Group II & Group III & Group I \\
\hline Abnormal & Antlcred & Band & Bent \\
\hline & Apterous & Beaded & \\
\hline Bifid & Arc & Cream III & \\
\hline Bow & Balloon & Deformed & \\
\hline Cherry & Black & Dwarf & \\
\hline Chrome & Blistercd & Ebony & \\
\hline Cleft & Comma & Giant & \\
\hline Club & Confluent & Kidney & \\
\hline Depressed & Cream II & Low crossover & \\
\hline Dotted & Curved & Maroon & \\
\hline Eosin & Dachs & Peach & \\
\hline Facet & Extra vcin & Pink & \\
\hline Forked & Fringed & Rough & \\
\hline Furrowed & Jaunty & Safranin & \\
\hline Fused & Limited & Sepia & \\
\hline Green & Little crossover & Sooty & \\
\hline Jaunty I & Morula & Spineless & \\
\hline Lemon & Olive & Spread & \\
\hline Lethal 1 & Plexus & Truncate intens. & \\
\hline Lethal 1a & Purple & Trident & \\
\hline Lethal 2 & Speck & White head & \\
\hline Lethal 3 & Strap & White occlli & \\
\hline Lethal 3a & Streak & & \\
\hline Lethal 4 & Tip & & \\
\hline Lethal 5 & Trefoil & & \\
\hline Lethal 6 & Truncate & & \\
\hline Lethal 7 & Vestigial & & \\
\hline Lethal B & & & \\
\hline Lethal Sa & & & \\
\hline Lethal Sb & & & \\
\hline Lethal Sc & & & \\
\hline Miniature & & & \\
\hline Noteh & & & \\
\hline Reduplicated & & & \\
\hline Ruby & & & \\
\hline Rudimentary & & & \\
\hline Sable & & & \\
\hline Shifted & & & \\
\hline Short & & & \\
\hline Skee & & & \\
\hline Spoon & & & \\
\hline Spot & & & \\
\hline $\operatorname{Tan}$ & & & \\
\hline Truncate intens. & & & \\
\hline Vermilion & & & \\
\hline White & & & \\
\hline Yellow & & & \\
\hline
\end{tabular}

It is not impossible that certain features of hereditary make-up may be carried in the cytoplasm. The earliest 
structures of the embryo appear to be determined by something within this extra-nuclear material of the ovum (Fig. 12). But the amazing parallel between the behavior of the microscopic chromosomes and the gross features inherited by the adult is enough to convince the majority of biologists that the chromosome-theory must be accepted as a working hypothesis of the mechanism of heredity.

The peculiarities of Mendelian inheritance are explicable in terms of chromosomes. Mendel's law may be illustrated by the inheritance of feather color in a cross between two particular varieties of poultry, one of which is black and the other a white with black splashes (Fig. $17 \mathrm{P}_{1}$ ). This is not one of the cases originally described by Mendel, who worked exclusively with plants, but it is one of the best for introductory purposes. When individuals of the black or the white type are bred among themselves the offspring are black and white respectively, showing that black and white are pure. But when one of these blacks is bred with a white, $100 \%$ of the resulting offspring $\left(F_{1}\right)$ are blue. This seems like blended inheritance. We should naturally expect that blue crossed with blue would give blue in subsequent generations. But Mendelian heredity is not of this nature.

The result which appears when the $F_{1}$ blues are bred together illustrates the distinctive feature in Mendelian heredity. If the numbers are sufficient, a theoretical ratio of 1 Black: 2 Blue: 1 White is approximated. The blacks of this $F_{2}$ generation give only pure blacks when bred among themselves, the whites only pure whites. A black bird of this generation is as pure black as its black grandparent, and the same is true of the white. Segregation of the black from the white has occurred. The seeming blend of the $F_{1}$ generation was not permanent, although similar individuals comprise the $50 \%$ of Blues in the $\mathrm{F}_{2}$. These $\mathrm{F}_{2}$ blues when bred among themselves give the same results as the $\mathrm{F}_{1}$ blues, namely, 25\% Black: $50 \%$ Blue: $25 \%$ White. The results obtained by breeding these $\mathrm{F}_{3}$ individuals are as previously 


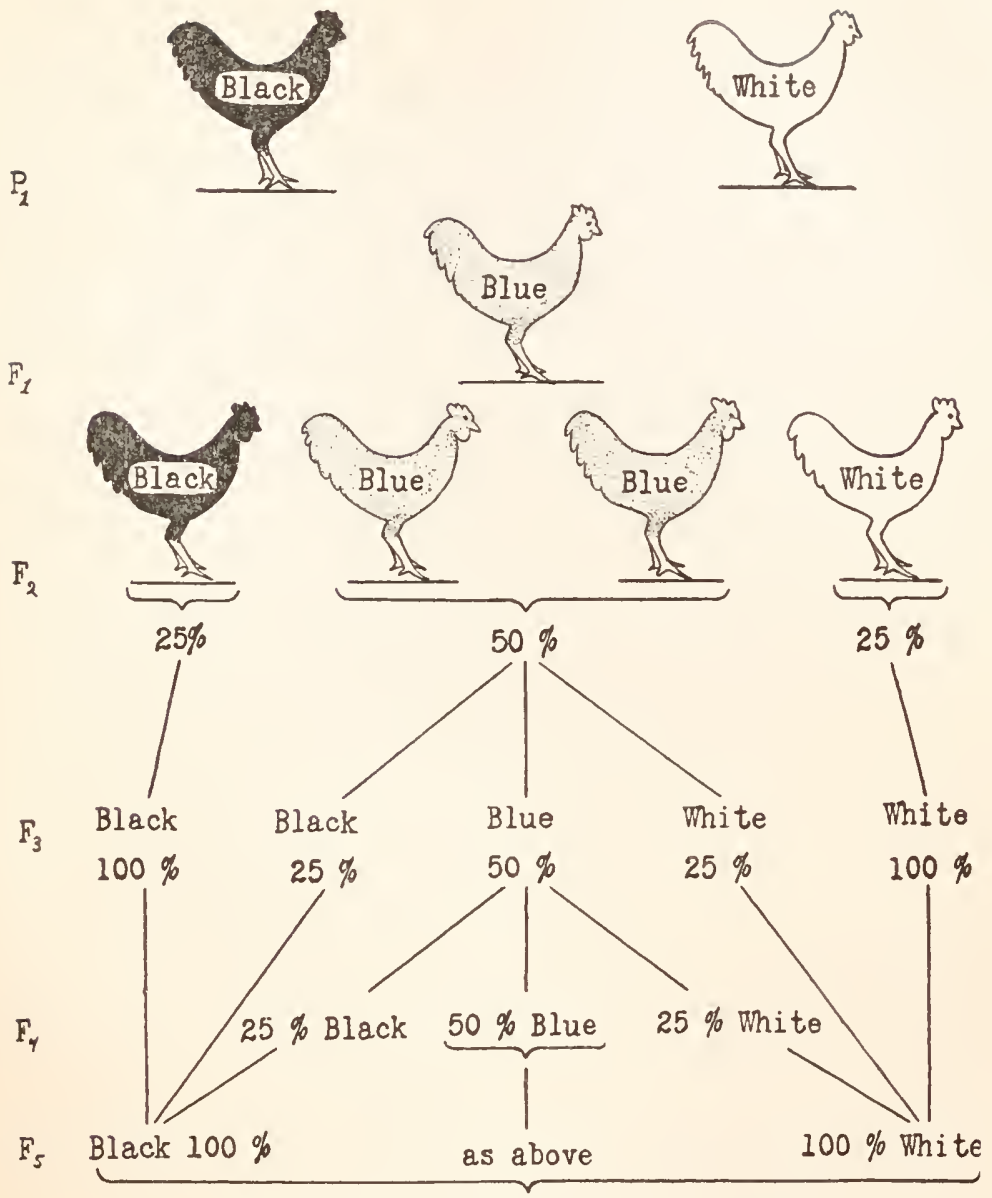

The same in subsequent generations

Fig. 17. Mendelian Heredity in Coloration of Blue Andalusian Fowl. As shown by the figure the blue andalusian cannot be established as a breed, because it is the hybrid produced by crossing a black and a white breed together and because Mendelian segregation is continually separating out pure whites and blacks in subsequent generations. The breeder can, however, secure 100 per cent of blue andalusians by crossing the white and black. $\mathrm{P}^{\prime}$, first parental generation; $\mathrm{F}^{\prime}$, etc., first filial and subsequent filial generations. 
found :-Black $\times$ White $=$ Blue; Blue $\times$ Blue $=25 \%$ Black $:$ $50 \%$ Blue : $25 \%$ White; Black $\times$ Black $=$ Black; White $\times$ White $=$ White. Similar results appear in all subsequent generations.

It thus appears that by following the middle percentage of Blues one might trace an exclusively blue line of descent through many generations. If nothing were known of the collaterals, it would seem that the black and white had permanently blended into blue. In small numbers, only blues might occur and what is essentially a non-blending type of inheritance would not be recognized as such. This might easily be the case in records of human families. The essential feature in Mendelian heredity is this absence of blending, as shown by the segregation of characters in the $\mathrm{F}_{2}$ and in subsequent generations. The black and white are united in the hybrid, but the latter does not give rise to a hybrid race that breeds true. Hybrids do appear, but along with them are the two original stocks in the fundamental $1: 2: 1$ ratio. $^{4}$

The adult individual may thus be pure or hybrid. In a case like the foregoing, the hybrid is recognized by its appearance. In some cases of Mendelian heredity, a phenomenon known as dominance occurs. One member of a pair of heritable qualities dominates the other to such an extent that the hybrid cannot be distinguished from a pure individual of the dominant type. The cross between gray and white mice will illustrate the facts. In this instance the gray is dominant, the white recessive. ${ }^{5}$ The results are as

${ }^{4}$ The blue fowls described above have long been known as Blue Andalusians. This supposed breed was found impossible to establish in any degree of purity, because when Blue Andalusians were bred together an annoying percentage of black and of white birds appeared. The mystery is now explained. The blue is a Mendelian hybrid and, therefore, can never be established as a pure breed, although $100 \%$ of blues can be secured by the simple expedient of mating the black and white wasters which so annoyed the breeders. Blacks and whites are the pure stock.

${ }^{5}$ There is no adequate explanation of why one member of a contrasting pair of characters should thus dominate the other. It is simply observed to be so 
shown in Fig. 18. The $F_{1}$ individuals present the same appearance as the dominant parent. They are without exception gray, as though they were pure gray mice. The recessive feature is as though absent. But these $\mathrm{F}_{1}$ mice cannot be exactly like the pure grays of the $P_{1}$, because they had one white parent. There must, therefore, be two kinds of grays, those which have two pure gray parents and those which have one pure gray and one white parent. The existence of two kinds of grays is proved by the subsequent breeding. In the $\mathrm{F}_{2}$ generation the white reappears. The ratio is $75 \%$ gray to $25 \%$ white, as shown by the figure. Study of these $\mathrm{F}_{2}$ individuals solves the problem. The $1: 2: 1$ ratio is present, only it is masked by the dominance of gray over white. The $75 \%$ of gray mice is shown by breeding tests to consist of $25 \%$ pure gray like the $\mathrm{P}_{1}$ grandparent, plus a $50 \%$ of hybrid grays like the $\mathrm{F}_{1}$ generation. The real ratio is: $25 \%$ Pure Dominants: $50 \%$ Hybrid Dominants: $25 \%$ Recessives. The recessives are always distinguishable, since they are what they seem to be on the outside. The dominants are of two types-pure and hybrid. Using symbols, the formula $1 \mathrm{DD}: 2 \mathrm{DR}: 1 \mathrm{RR}$, or $1 \mathrm{GG}$ : $2 \mathrm{GW}: 1 \mathrm{WW}$ expresses the facts. It happened that dominance appeared in the cases originally described by Mendel. Its importance was consequently overrated. Many instances are now known in which dominance is incomplete and others in which the terms dominant and

in particular cases. Dominance may be incomplete, in which event the hybrid can be at once distinguished from the dominant parent. Where dominance is complete the hybrid and the dominant parent are indistinguishable. In many cases the dominant character is observed to be the presence of some quality and the recessive character the absence of the same. Thus the gray mouse has pigment present in its coat, the white mouse has pigment absent. The normal human eye has pigment present, the albino eye is devoid of this characteristic, so that albino eyes are red being colored only by the blood. These facts have led to the presence-and-absence theory, which explains dominance in the manner indicated. Incomplete dominance in the $F_{1}$ generation might be described by saying that of ten a single dose of the character is not sufficient to give complete resemblance to the dominant parent. 


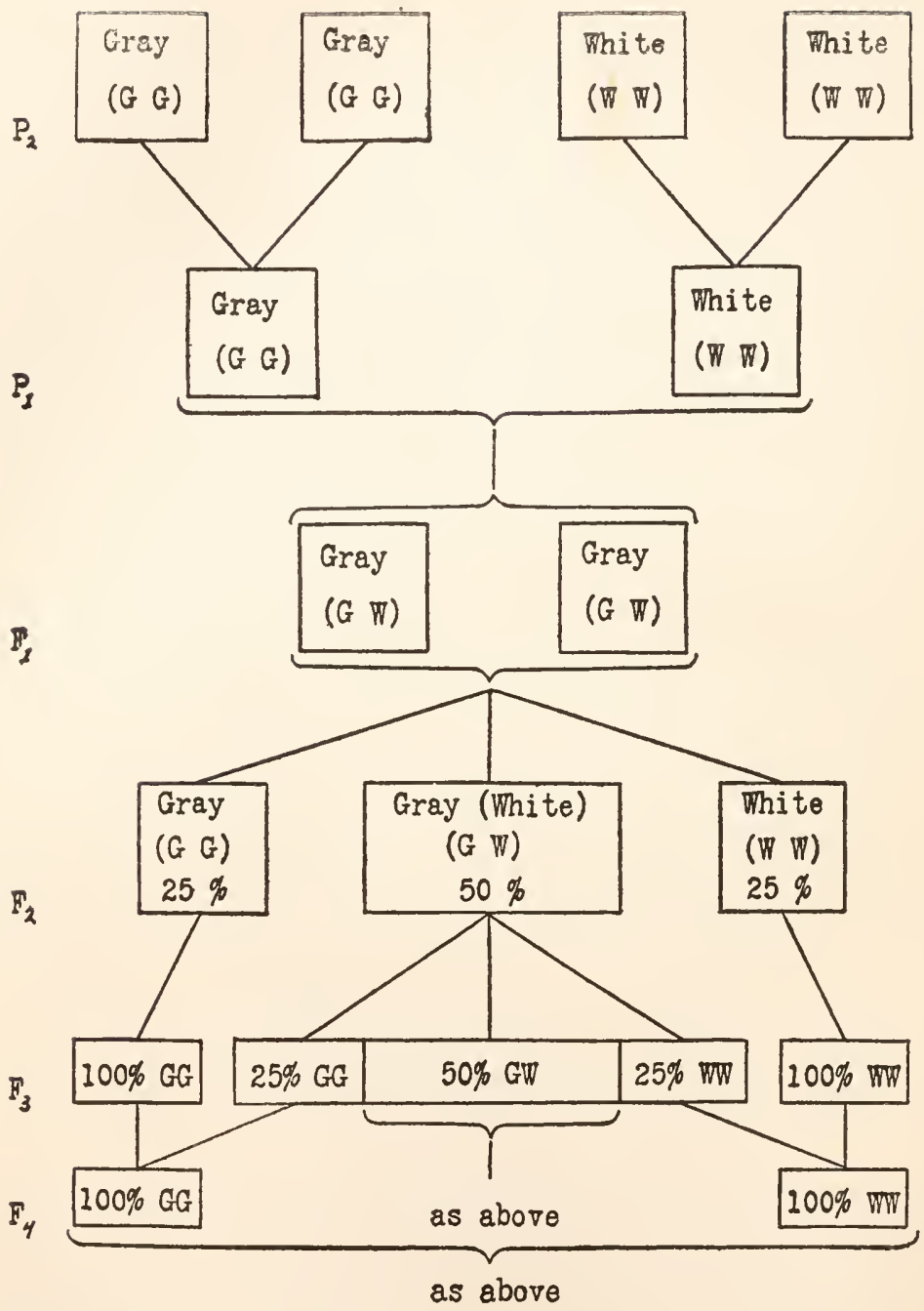

Frg. 18. Dominance of Gray over White in Inheritance of Coat Color in Mice. The squares represent adult individuals; the letters in parentheses the hereditary constitution. $\mathrm{P}_{1}, \mathrm{P}_{2}, \mathrm{~F}_{1}$, etc., as in Fig. 17. 
recessive are hardly applicable, since the hybrid differs from each of the parents. Segregation not dominance is the essential phenomenon in Mendelian heredity.

In the foregoing account the results visible in the adult animals have been described without explanation of the causes for this peculiar type of inheritance. Mendel's claim to distinction lies in the fact that he explained the ratios observed in segregation in a manner which has stood the test of later investigation. He knew little of germ-cells. In his day the finer details of fertilization were still undiscovered. He knew merely that there were male germs or pollen grains and female germs or ovules. His explanation of segregation as he would have applied it to the Blue Andalusian, had he worked with that form, may be stated as follows: The original black individuals, $P_{1}$ in Fig. 19, are pure blacks, since they arise from a black ancestry and give only black descendants when bred among themselves. The same holds for the $\mathrm{P}_{1}$ whites. The symbol B B may be used to designate the black adults and $\mathrm{W} W$ the whites. The doubling of the letters indicates that the individuals arise from a double parentage. The blue or hybrid would then be designated as $\mathrm{B} \mathrm{W}$. In the figure referred to, the squares stand for adult individuals, the circles for germ-cells. The latter are represented with the character B or W taken once, so that the union of two germ-cells gives the B B, $\mathrm{B} W$, or $\mathrm{W} W$ of the adult formula. We are now in a position to understand Mendel's explanation of segregation.

The $\mathrm{P}_{1}$ Blacks (B B) arise from germ-cells carrying black; and can produce only germ-cells carrying black; the $\mathrm{P}_{1}$ Whites (W W) only germ-cells carrying white. The hybrid, being a union of white-carrying and black-carrying germs, is B W. The problem now arising is what kind of germcells will the hybrid $\left(\mathrm{F}_{1}\right)$ produce. Will they carry both $\mathrm{B}$ and $\mathrm{W}$ or will they carry $\mathrm{B}$ or $\mathrm{W}$, the one to the exclusion of the other? The first hypothesis does not aid us in explain- 
ing segregation. The second might seem improbable, but it can be accepted if it explains the facts. Suppose, therefore, that the $F_{1}$ germ-cells do not carry $B$ and $W$, each diluted one-half, but $\mathrm{B}$ or $\mathrm{W}$, and that the two kinds of germ-cells thus produced are present in equal numbers. The case would then be as shown by the figure.

Suppose further, that each kind of germ-cell has equal chances in fertilization. Referring to the diagonal lines below the $\mathrm{F}_{1}$ germ-cells (Fig. 19), the germ-cell $\mathrm{B}$ may unite in fertilization with another cell $\mathrm{B}$ or with a cell W; the cell $\mathrm{W}$ may unite with a cell $\mathrm{B}$ or with a cell $\mathrm{W}$. This exhausts the theoretical possibilities and gives the ratio $1 \mathrm{~B} \mathrm{~B}: 2$ $\mathrm{B} \mathrm{W}: 1 \mathrm{WW}$, by the laws of chance. It is the same as in matching heads and tails with a coin. If you throw heads your opponent"may throw heads, if you throw heads he may throw tails, if you throw tails he may throw heads, if you throw tails he may throw tails; which would be $1 \mathrm{H} \mathrm{H}: 2$ $\mathrm{H} \mathrm{T}: 1 \mathrm{~T} \mathrm{~T}$ A simple algebraic multiplication also illustrates the case: $(x+y) \times(x+y)=x^{2}+2 x y+y^{2}$. The fundamental ratio of $1: 2: 1$ is thus explained as due to chance combinations of germ-cells which are pure, in the sense that they carry that which determines one member of a contrasting pair of adult characters to the exclusion of the other. Purity of the germ-cells with reference to the paired unit-characters of the adult is thus a primary assumption in the explanation of Mendelian ratios.

The principles of Mendelian inheritance as thus disclosed are: (1) that an adult animal possesses unit-characters, which (2) segregate in heredity, and (3) that the determiners for contrasting unit-characters are not carried together in the same germ-cell. An adult organism is a mosaic of these unit-characters, not a blend. Contrasting unit-characters may be combined in the individuals of an $\mathrm{F}_{1}$ generation, but in subsequent generations they segregate in definite ratios. The existence of the ratios is explained by assuming that the germ-cells are thus pure with respect to a pair of 


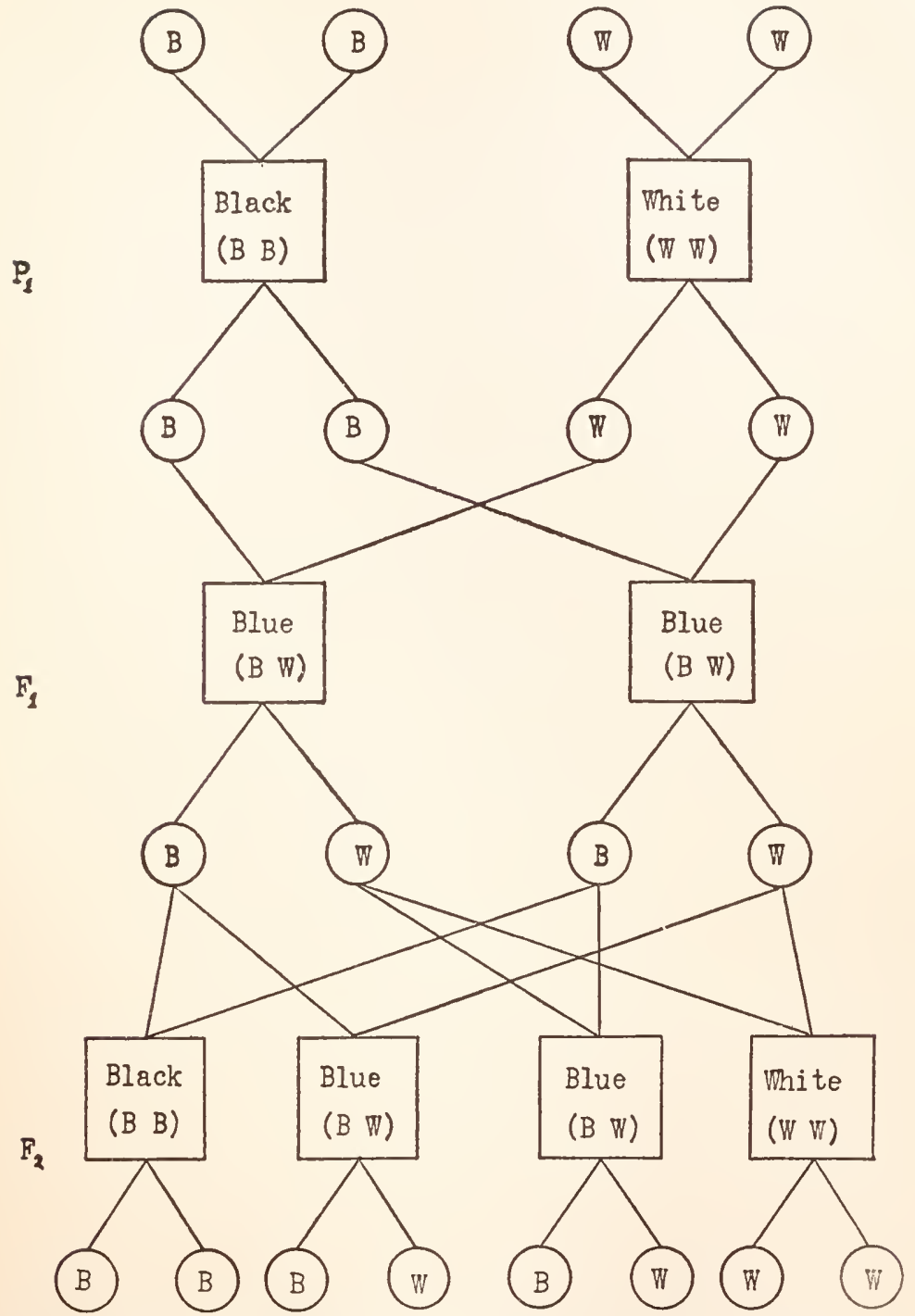

Fra. 19. Explanation of Mendelian Segregation in Terms of Germ-Cells. The cases originally studied by Mendel were in the edible pea. The present figure shows how the explanation which Mendel offered applies to the color of the blue andalusian fowl. Compare with Fig. 20, showing the modern extension of Mendel's explanation in terms of chromosomes. See discussion in text. Squares represent adult individuals, circles ova and spermatozoa. $\mathbf{P}_{1}$, etc., as in previous Figs. 
characters like the black and white and that combination occurs by chance.

The application of the cell-theory in the foregoing explanation of the $1: 2: 1$ ratio is obvious. The germs to which Mendel referred in general terms are germ-cells. Fertilization is a fusion of two cells, each containing one-half the normal number of chromosomes. The modern chromosometheory of heredity, which is a theory of intra-cellular organization, furnishes an even more precise explanation of the phenomena. The most important discoveries since the work of Mendel have been those relating to the chromosomes in heredity.

In illustration of the relationship between chromosome behavior and Mendelian heredity, a pair of characters may be arbitrarily represented by $A$ and $a$. The use of the large letter expresses the fact that $A$ is dominant while $a$ is recessive, The use of two letters of the same sort, rather than two different letters, shows that $A$ and $a$ are a contrasting pair of Mendelian unit-characters. The pure adults would, therefore, be designated respectively as $A A$ and $a a$; the hybrids as $A a$. Suppose the number of chromosomes in the body cells is four pairs, which means four single chromosomes to a germ-cell, $i$. e., one member of each pair ( $c f$. Fig. 16). The case may be represented as in Fig. 20, again using squares for adults and circles for germ-cells. The addition of globular bodies indicates the chromosomes as they occur in every cell of the adult body and in the germcells.

Assume that the $A$ determiner is carried in one of the pairs of chromosomes of the dominant individual and the $a$ determiner in the corresponding chromosomes of the recessive. This may be indicated by writing the letters upon the chromosomes in question. When reduction in the number of chromosomes occurs, during the final ripening of ova and spermatozoa, the result is as shown in the $P_{1}$ germ-cells of Fig. 20. Each germ-cell possesses but one of the chromo- 


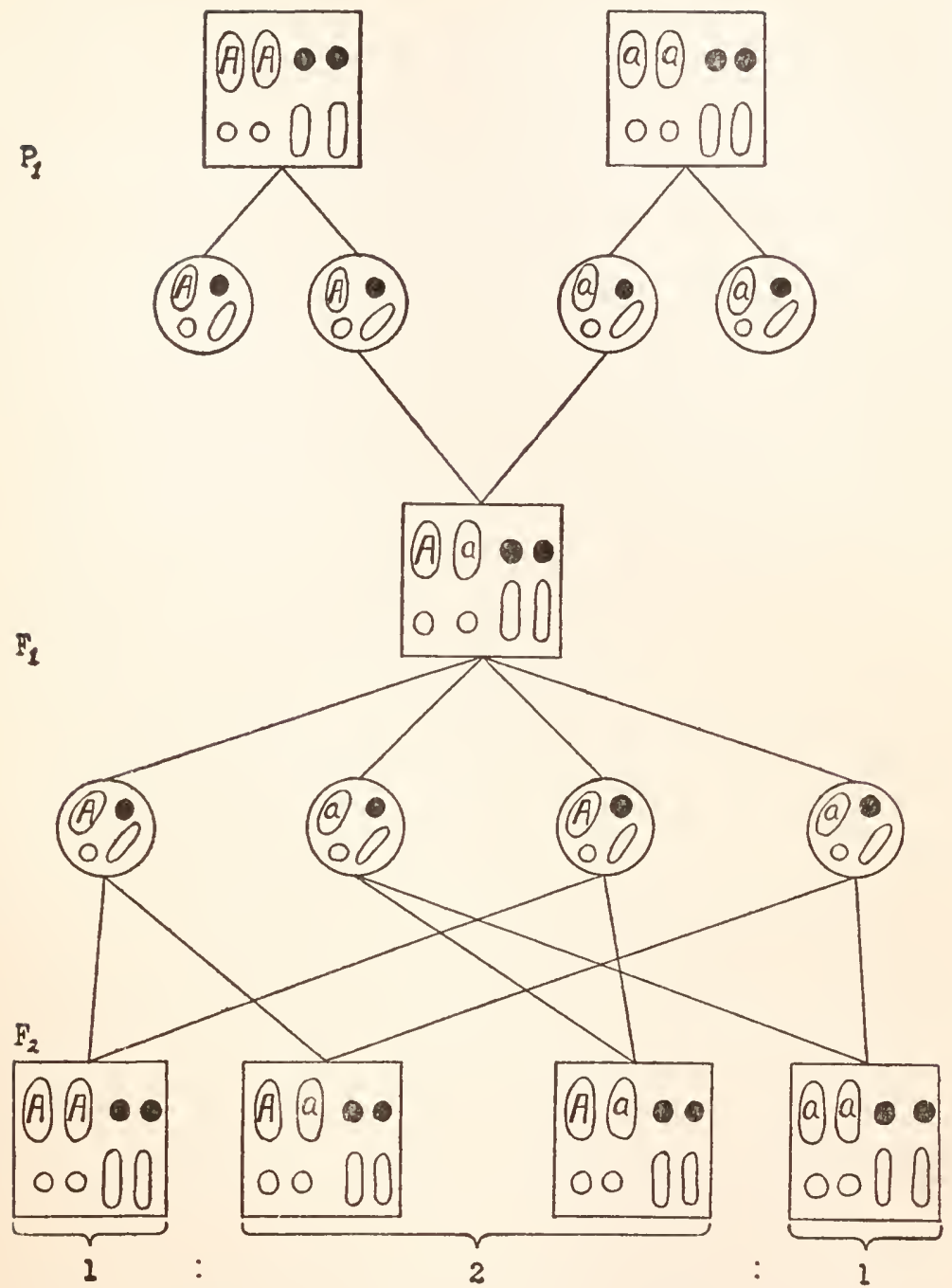

Fig. 20. Explanation of Mendelian Segregation in Terms of Chromosomes. The number of chromosomes is taken as four pairs in cells of adult body, reduced to one member of each pair in the ova and spermatozoa. See discussion in text. Squares and circles as in previous figure. 
somes to which the characters have been assigned, and hence what might be described as a single dose of the character in question. Union of the germ-cells to form the $F_{1}$ adult produces an $A a$ combination in this pair of chromosomes. The germ-cells of the $F_{1}$ will be as shown, because reduction of the chromosomes to one-half the adult number occurs by disjunction of the members of the pairs. Combination of these $\mathrm{F}_{1}$ germ-cells will occur in the $1: 2: 1$ ratio, as indicated by the $\mathrm{F}_{2}$ adults of the figure, on the assumption of their union by the laws of chance.

Thus the arrangement and behavior of the chromosomes is of such a nature as to explain segregation. The hypothesis that the determiners for adult characters are carried by the chromosomes is justified by the outcome. The chromosomes are distributed in a manner that parallels the heredity of the members of a contrasting pair of unit characters.

The foregoing explanation of Mendelian heredity by means of chromosomes is an explanation in terms of cells. Only, the analysis has gone deeper and disclosed the portion of the cell that is primarily concerned. The diagnosis is more complete than has been indicated here, giving consistent results where additional pairs of characters are involved. ${ }^{6}$ But the foregoing explanation is sufficient to show that the mechanism of Mendelian heredity is a cellular one. Just as the visible structure and functioning of the body are referable to microscopic cells, so is the inheritance of structure and function. Development consists of cell division and differentiation from a single-celled organism, the oösperm, to a many-celled organism the adult (Fig. 12). There is cellular continuity between generations. Herein lies the physical basis of heredity. It seems inconceiveable that a single cell should contain within its limits an organization capable of producing an adult if only a suitable environment is provided. But where adult characteristics are

${ }^{\circ} C f$. Table on p. 133 of the present volume, and the account of the chromosome theory of sex determination on p. 204. 
shuffled about as in Mendelian heredity, it is necessary to suppose not only that the adult is in some manner contained within the germ but also that something within the germcells can be shuffled in a corresponding manner. These somethings, which are called determiners, genes, or factors, appear to be located in the chromosomes. Superficially, development is a process of building the adult organism a step at a time-epigenesis. When examined more closely, it is a coming into being of what is potentially existent, just as the dealing of hands at cards is the production of an end result foreshadowed by an arrangement within the pack. To this extent the concept of preformation is applicable to development. ${ }^{7}$

If the cell must furnish clues to the resemblances between generations it must also furnish clues to variation. Heredity and variation are simply different aspects of the reproductive process. Like begets like, but not just like. We often speak of heredity and variation as conflicting forces. They are merely the two sides of development. Heredity and variation are the initial processes in evolutionary change. Explain these two phenomena and you explain the starting points of evolution. Cell-theory and evolutionary theory here meet. The discovery of a cellular mechanism for Mendelian heredity establishes a continuity between fields of biological knowledge which are at first glance distinct. ${ }^{8}$ Investigators continue to approach the evolution-

${ }^{7}$ A brief discussion of the modern concept of the relation between preformation and epigenesis in development appears on p. 193 of the present volume. Cf. also: Parker, G. H., "Biology and Social Problems," Chapt. III, Reproduction.

${ }^{8}$ Recognition of cell problems as related to evolutionary problems first appears in the writings of August Weismann (1834-1914). The nature of the genetic continuity between parent and offspring having been established, Weismann realized that once in each generation the potentialities of the individual, and so of the race, are encompassed within the limits of single cells-the ovum and the spermatozoön, and the oösperm formed by their union. Whatever restrictions subsequent investigation may place upon his conclusions, Weismann will remain a commanding figure, because he first brought into correlation the two major lines of biological interest. 
ary problem from the side of adult organization rather than from the side of individual development. But the fact is acknowledged that evolutionary origins must, in the last analysis, be explained as changes originating within cells and perpetuated by a cellular mechanism.

\section{RAMIFICATIONS OF THE CELL-THEORY}

Within the field of physiological science, as well as in zoölogy, applications of the cell-theory were the great achievement of the nineteenth century. When bodily. activities were seen to be nothing but cell activities, the way was opened for a comprehensive explanation of all general functions in both animals and plants. Take the production of a secretion such as saliva, gastric juice, or perspiration: The older physiologists had studied the phenomena which were visible to the unaided eye. The nature of secretions had been investigated, so far as chemical knowledge allowed. Many interesting phenomena had been ascertained. ${ }^{9}$ There remained the problem of how the chemical compounds dissolved in the water of a particular secretion were produced and secreted. The series of chemical changes involved in the process is still incompletely known. The setting can, however, be described in terms of cells.

One of the glands in the skin of a frog will illustrate what happens in cases where the secretion is passed to the outside or to an internal cavity like the stomach. The gland in this instance is relatively simple, consisting of a flask-

${ }^{9}$ A classical example is the work of the American physician, William Beaumont, who was fortunate in having under observation, for some years following 1822, a soldier who had been wounded in the stomach and whose wound had healed in such a manner that an orifice remained through which the processes of secretion and digestion could be observed. Many problems of gastric digestion are still investigated, in a fashion comparable with that pursued by Beaumont, without reference to the origin of the gastric juice within the cells, but the formation and liberation of any secretion is a cellular function. 


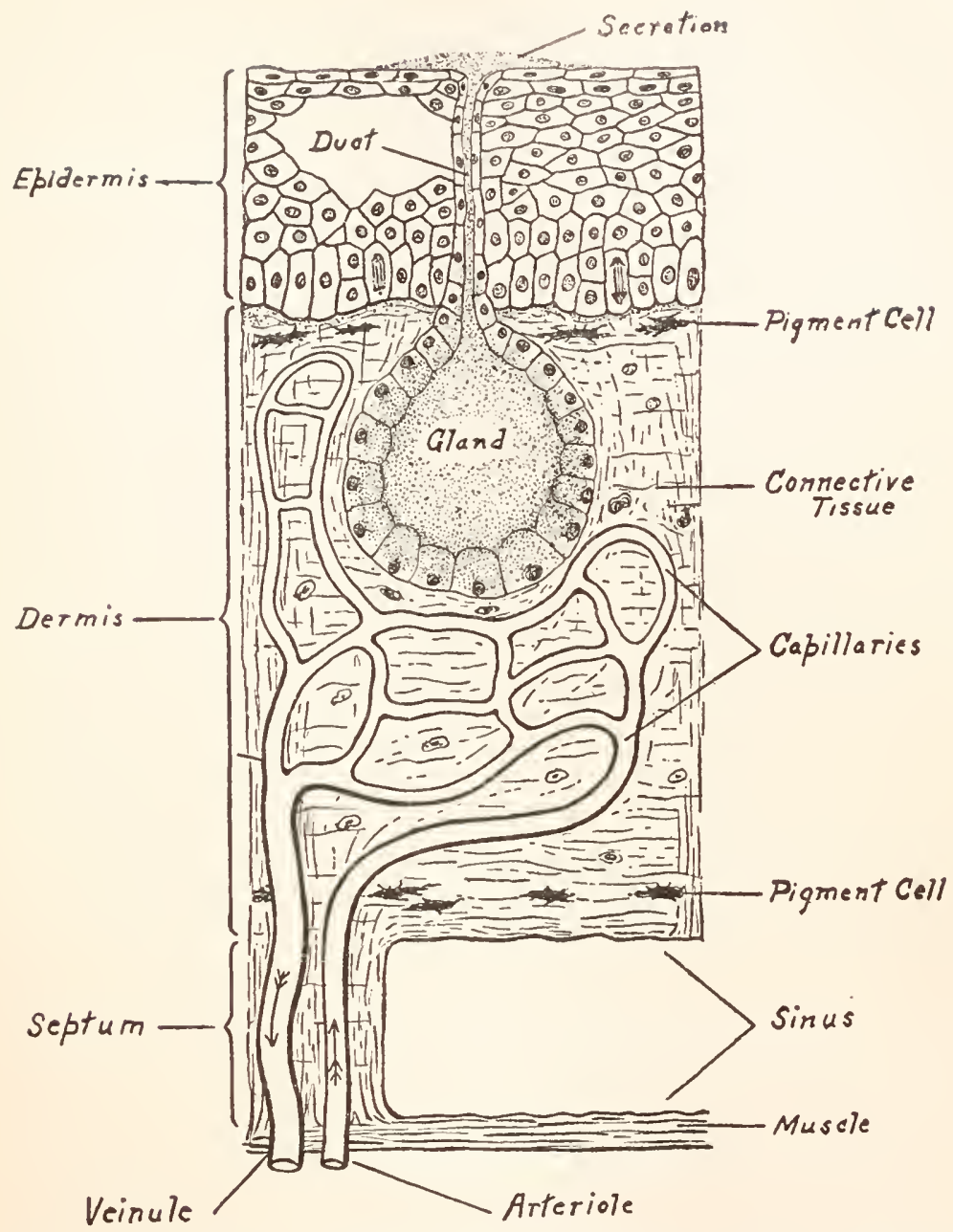

FIG. 21. Diagrammatic Vertical Section through Skin of Frog. Showing cellular structure and parts.

shaped cavity, with the neck opening as a pore on the outer surface of the skin (Fig. 21). Lining the gland is a single layer of cells. Outside is a network of capillaries, through which passes a constant flow of blood. Each gland-cell produces within itself a substance, which, if not the actual 
secretion, contains the parent chemical compounds out of which the secretion is formed as it passes from the cell into the central cavity. The gland-cell is like a factory, which receives certain raw material delivered by a common carrier at the back door, and transforms it into a product that is passed out on the other side. The blood is the carrier of raw material, which the gland-cells receive and which they convert into the secretion exuded into the cavity of the gland and thence passed to the outside. A substance like water, which is, of course, present in all secretions, passes through the cells unchanged. The substances distinctive of a particular secretion, and not present in the blood, must, obviously, be manufactured within the gland-cells from material received from the blood. The gland-cell, therefore, resembles an industrial establishment engaged in the manufacture of chemicals. Some of the physico-chemical processes which occur in cells of this nature are well established. Others remain to be discovered. No one claims that having thus localized the formation of a secretion within the cell, he has explained the ultimate vital phenomena. The point is that in secretion, as in other vital processes, the structural and so the functional basis for what goes on is a cellular basis. The phenomena of muscle and nerve might be traced in like manner to their cellular foundation. Structure and function are everywhere explicable in terms of cells.

The science of physiology was thus advanced from a study of gross phenomena, such as the mass-contraction of a muscle, the conduction of a nerve-impulse, or the simple features of a process like secretion, to an examination of cellular activities underlying the more obvious phenomena. The publication of Verworn's classical work upon "General Physiology," 10 in which the problems of physiological science were attacked as cell problems, expressed this progress from the study of functional activity in the mass to its study within the cell. It also indicated the advance toward ${ }^{10}$ Verworn, M., "Allgemeine Physiologie," 1895. 
a mechanistic explanation of vital phenomena. For whatever one may think of the relative merits of vitalistic and mechanistic concepts of the life-process, the history of biological science shows that the forward steps have usually consisted of further extensions of chemico-physical, and hence of mechanistic, explanations.

This development within the science of physiology exerted a profound influence upon the progress of medicine. The theory of cells led to medical advances which were unthought of at an earlier period. We find here the most advanced phase in that control of nature, which may distinguish biological science in the future. During recent years the physiologists have laid the foundations for changes in medicinal science as far-reaching as those necessitated by the germ-theory of disease. Their studies in nutrition, in secretion, in the chemistry of blood and tissue, and the like are restricting the art of medicine and forcing progress along the lines of science. These investigations could never have reached their present state in the absence of some comprehensive theory of microscopic organization. ${ }^{11}$

The theory that certain diseases are caused by minute organisms or germs, living as parasites within the bodies of animals and plants, has been intimately associated with the theory of cells. Analogies between the spread of disease and the multiplication of living organisms were long recognized, without being explained. For centuries, a variety of disorders were attributed to parasitic worms, although the life-cycles of forms like tapeworms were not ascertained until the middle of the nineteenth century. Minute parasites had, however, been observed within the bodies of larger animals since the early days of the microscope The finding of bacteria in association with particular diseases was, therefore, a suspicious circumstance. The Germ-Theory of disease was established, in correlation with the cell-theory, during the third quarter of the nineteenth century.

${ }^{11}$ Cf. Lee, F. S., "Scientific Features of Modern Medicine." 
The confirmation of the germ-theory as a scientific fact begins with Pasteur (1822-1895). Working as a chemist, this great Frenchman undertook to investigate fermentation. He found that each kind of fermentation, had associated with it a particular kind of organism. Thus the wineyeast was always present in fermenting wine, the brewer's yeast in beer, the bread-yeast in dough. The organisms were necessary for the process. They were also specific for' particular fermentations. The so-called diseases of fermentation, which had caused such heavy losses to the winemakers and brewers of France, were caused by the presence of the wrong kind of organism or by some abnormality of functioning in the one normally causing the fermentation. The grosser features of the process, such as liberation of gas and the manner in which a little leaven could leaven the whole, had long been recognized. Now, the chemical processes involved and their causation through the activities of specific organisms-yeasts and bacteria-were made known. The decay of organic matter, and its accompanying fermentation, was explained as caused by microörganisms. The idea was formed that diseases in man and domesticated animals, as well as in wines and beer, might likewise be caused by microscopic germs.

Following his work upon fermentation, Pasteur undertook the study of a disease of silk-worms, which had caused great financial loss to the silk-raisers of France. He proved that there were two specific diseases among the worms, each of them caused by parasitic bacteria. The problem thus became one of preventing the worms from becoming infected, with the bacteria, since there was no disease save as it arose from the parasitic germs. Pasteur next turned his attention to the disease known as anthrax and again discovered a specific germ, the Anthrax bacillus. Subsequent work upon rabies and other diseases led to the preparation of vaccines for particular maladies. In this manner Pasteur and his successors not only established the germ-theory of 
disease but also the present practice of vaccination for a variety of diseases. ${ }^{12}$

The germ-theory of disease stimulated renewed interest in the problem of generation. If organisms originated de novo or spontaneously, their appearance was due to conditions within the medium in which they appeared. If they arose from preëxisting organisms by reproduction, their appearance was due to conditions under which they obtained entrance. Pasteur and other workers during the sixties and seventies of the last century gave the death blow to the theory of generation de novo. Microscopic forms were shown to have life-cycles comparable with those of larger organisms. Prevention and curation in a large class of diseases became the problem of preventing the entrance and effecting the destruction of parasitic germs. Contagion was at length explained.

Remarkable applications of the above principles appeared in surgery. The surgical wards of the hospitals had formerly been veritable pesthouses for wound-infections. No precautions availed. ${ }^{13}$ Lord Joseph Lister (1827-1912) applied to surgery the principles discovered by Pasteur. The suppuration of a wound was the putrefaction of organic material. Putrefaction elsewhere was caused by microscopic organisms. Exclude or destroy the organisms and there would be no suppuration. Lister's results were amazing. Surgery in which the germs were destroyed by means of

${ }^{12}$ Before Pasteur, certain general features of the germ-fact of disease and of the reactions of the body to such invasions had been discerned, for example, the discovery by Jenner (1796) of vaccination against smallpox. What Pasteur did was to give the first complete demonstrations of diseases as caused by parasitic organisms, of infection as merely the entrance of the parasites, and of the control of germ-diseases by vaccinations. A host of facts long known to the medical profession at once became intelligible.

${ }^{13}$ During the American Civil War hospitals were even torn down and new ones constructed in vain attempts to stamp out gangrene. But all to no avail, for the surgeons unknowingly carried the infection attached to their instruments and persons. This leaven soon leavened the new establishment so that wound-disease was again rampant. 
antiseptics was the outcome. Infection came to be the mark of a bungling surgeon or a rare accident. Subsequently, the methods of antisepsis have been in part replaced by those of asepsis and by methods which enable the natural bodily processes to destroy the germs that may find entrance. ${ }^{14}$

The work of Koch (1843-1910) is representative of investigations which established the principles of treatment and diagnosis now universal for infectious diseases. His discovery (1882) of the bacillus of tuberculosis was epochmaking. Bacteriology came into existence as a distinct science during the last quarter of the nineteenth century, when a long list of diseases were found either to be caused by recognizable germs or to behave in such a fashion as to indicate germinal causation. With the confirmation of the mosquito-malaria theory, an important disease was shown to be caused by a protozoön. During the last twenty-five year's, the list of such infections has been so rapidly extended that protozoa have assumed an importance second only to bacteria as disease-producing organisms. The important rôle of insects, like mosquitos and house-flies, in the transmission of disease has been discovered within the same period. The immediate application of such knowledge in medical practice renders these discoveries matters of common information.

The germ-theory thus brought revolutionary developments within the two main branches of medical science. Surgery and the treatment of disease became established on a new basis, because of the comparatively simple discovery that many diseases and the decay of organic matter are alike caused by the activities of microscopic organisms. Not all diseases are so caused, and the germs of certain infectious

${ }^{14}$ The story is vividly presented by the veteran American surgeon W. W. Keen, "Before and after Lister," Science, June 11, 1915. See also: "Medical Research and Human Welfare," by the same author; and the essay by $\mathrm{O}$. W. Holmes on "Puerperal Fever." 
diseases have yet to be recognized as such. Nevertheless, what is now the germ-fact stands as the most comprehensive generalization within the field of medicine.

The bearing of the cell-doctrine upon the germ-theory of infectious diseases is obvious. The latter could never have become established without detailed knowledge concerning cells. The germ-theory became established along with the fact of cellular continuity between generations. Just as the physical basis of heredity was disclosed in terms of cells, so the physical basis of contagion was found to be the unicellular germ. The one reacted upon the other, although the general theory of cells comprehended the particular theory of germs. It is not putting the case too strongly to say that the cell-theory changed the entire concept of the causation of disease, first, through its support of the germ-theory and, second, through its explanation of all pathological functions as abnormal cell activities. Not only were infectious diseases explained, but a clue was furnished for the explanation of all bodily disorders.

The history of the cell-theory illustrates the origin, development, and ramification of a fundamental hypothesis. A unifying explanation of innumerable disjointed observations was impossible without proper understanding of microscopic structure. As soon as the cell-theory was promulgated, its value was apparent. The organization of animals and plants, both great and small, was brought within the same category. The clue was discovered, both as regards structure and function, to the origin of the individual, and hence to the continuity between generations. Just as the evolutionary hypothesis unified a multitude of facts regarding visible structures and activities of living things, so the cell-theory unified the phenomena that underlie the visible features of the body as a whole. With such a theory established, biological science could attack the problems of the living substance with some hope for a successful issue. 
Cells are the units of structural organization. All normal functions are cell functions, and likewise all abnormal activities. The value of such a generalization is apparent. Its applications in medicine, in the problems of development, in heredity, and throughout the field of biological science, can be fully measured only by future accomplishment. The cell-theory has unified facts of the most diverse nature and has opened a way to the discovery of ultimate vital phenomena. Outside the field of evolution, the recent progress of biological science has been the progress of knowledge concerning cells. Even heredity and variation are themselves reducible to phenomena of the cell. 


\section{CHAPTER VII}

\section{THE BIOLOGICAL SCIENCE OF THE MODERN PERIOD: THE THEORY OF ORGANIC EVOLUTION}

The Cell-Doctrine and the doctrine of Organic Evolution are the two most fundamental generalizations thus far established in biological science. It is difficult to say which has been the more effective in unifying a wide range of established facts. As we have seen the cell-theory is a key to the structures and functions which are everywhere observable in animals and plants. Its significance in the history of living things is almost wholly by implication from what exists in the present. The theory of organic evolution is primarily significant as an explanation of the past. Whether we consider the one or the other the greater generalization depends upon whether we are interested in the immediate vital phenomena and their control by man, or attracted by the philosophical aspects of biology. Cell problems are problems of the present and of that part of the future which will be important to the human race. The problem of organic evolution is mainly a problem of the historical origin of the animal and plant bodies around us. The origin of the human species in comparatively recent times and the beginnings of life upon our planet are two of its most interesting aspects.

But organic evolution is only an aspect of the Evolution of the Cosmos. Evolutionary development has come to be accepted as the most reasonable explanation for the origin of what now exists. This is true, whether it be the bodies of animals and plants, the surface of the earth, or solar systems. Organic evolution is part of the cosmic evolution, by which the universe has reached its present organization. 
The origin of our solar system may be removed from the present by billions of years and the origin of our earth may seem too remote for explanation. But the records of the geological changes which have given the earth its present surface are within our comprehension; and there is no adequate reason for not extending the same kind of scientific explanations to beginnings that antedate what is ordinarily encompassed by the science of geology. The geologist takes up the problem where the astronomer leaves it. The latter may be vague and uncertain in his conclusions, but the presumption favors his evolutionary theories, because evolution so clearly appears to have taken place from the period at which the record began to be written upon the crust of our planet. As a part of the geological record, the history of animal and plant life is found imperfectly recorded in the rocks. ${ }^{1}$

Organic evolution is, therefore, not a theory of the origin of men from monkeys, but is concerned with the origin and development of all the animal and plant bodies which now exist; and it is part of the larger theory of cosmic evolution, which postulates that the visible universe has reached its present state by a process of change. This change is going forward in the present, and will, presumably, continue in the future. Concepts of infinite space and infinite time are involved. Man's claim to importance, in the dynamic system thus revealed, lies not in the pretense that this planet was prepared for his coming, but in the claim that he transcends the visible universe in so far as he comprehends it.

1 The limitations of the palæontological evidence are well set forth in a famous chapter in Darwin's "Origin of Species," entitled "On the Imperfection of the Geological Record." Despite the additions to knowledge which have since been made, the record must always remain fragmentary. Yet the evidence is sufficient to completely establish the fundamental fact of progression. 


\section{ANCIENT AND MEDIEVAL IDEAS REGARDING THE UNIVERSE}

The nature of the Hebrew-Chaldean tradition regarding the origin of mankind can be appreciated if we examine the stories concerning creation that are found in the mythology of other primitive peoples. Such stories differ widely in detail, but they almost always ascribe the beginnings of the world and of the particular tribe or people to the direct action of some deity who resembles a glorified human being. The tribe had its origin either directly from this being, as child from parent, or by his act of creation. While there are many variations of the theme, the idea of descent from, or creation by, a god, who is a glorified man, is the common foundation upon which the stories are elaborated. Of course, the fact that the creation mythology of widely separate peoples has features in common does not prove a common origin for the many traditions, and it certainly proves nothing as to the truth of these stories. The reasonable explanation is that primitive minds arrived at similar conclusions in the absence of pertinent data. When such parallelism exists, it is, presumably, because human minds follow similar channels. As mythology, such stories are a fascinating study for the ethnologist. The tradition of creation inherited by Christendom is interesting for comparison and because it has built itself into the thought of western civilization.

The account of the origin of man and of the animals and plants, which appears in the first chapter of Genesis as part of the general account of Creation, was probably derived by the Hebrews from their neighbors in Mesopotamia. It is a modification of a common tradition that, in its essentials, was shared by the early peoples around the eastern end of the Mediterranean. The assumed topography of the universe was quite definite, if we may judge from many references in the Old Testament; and these concepts of the Hebrews were not unlike those recorded by the Egyptians. According to this belief, the earth was regarded as a flat 
disk, covered by the sky which was like the ceiling of a dome and rested upon the mountains. It was supposed that on the east and west sides of this dome or firmament there were doors, through which the sun passed in the morning and

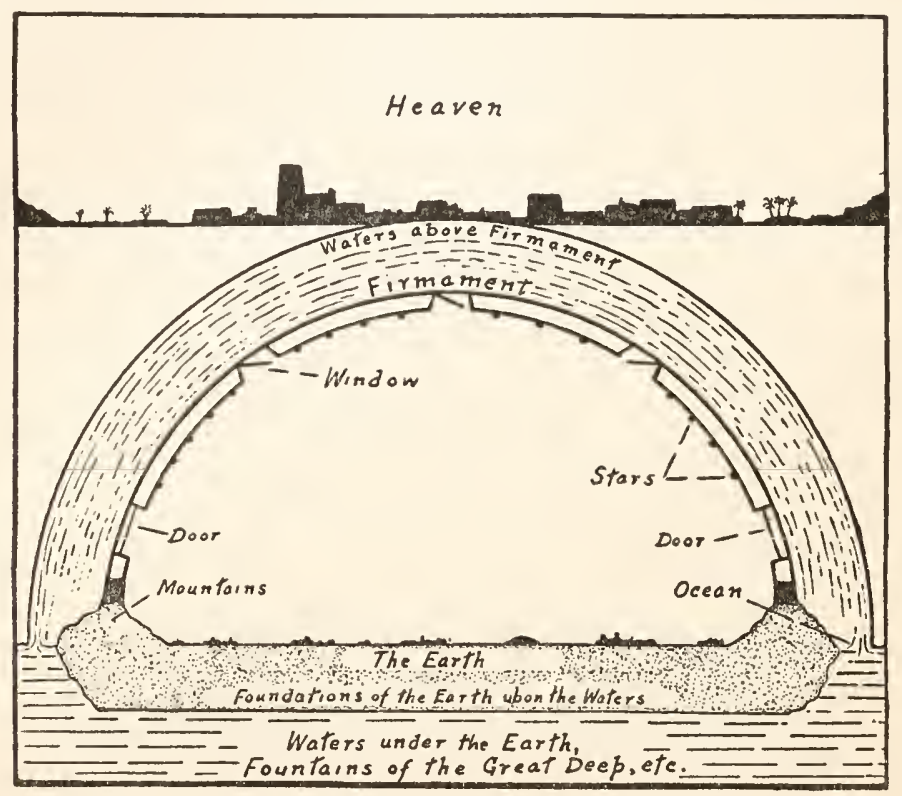

Fig. 22. Schematic Representation of the Hebrew-Chaldean Concept of the Universe. As indicated by references in the Old Testament. These ideas seem to have been obtained by the Hebrews from Mesopotamian and other earlier sources.

departed at night. The earth was surrounded by water upon which it floated and the water extended also above the firmament (Fig. 22). In the firmament were windows and the star's were fastened to its lower surface. Above the firmament was Heaven." Such expressions as, "the foundation of the earth upon the waters," "the foundations of the great deep," "the corners of the earth," "the pillars of heaven," "the waters above the firmament," "the sun

${ }^{2} \mathrm{Cf}$. the account of the universe by Cosmas, cited on p. 51 of the present volume, and that implied in Milton's "Paradise Lost." 
as a bridegroom coming forth from his chamber," "the windows of heaven," and many others are not mere figures of speech. They are indications of a picture of the universe which existed in the minds of the writers of the Old Testament. These phrases are thought-fossils which tell us the nature of the Hebrew concept of the world. ${ }^{3}$

The creation myths of the early Greeks were mainly of Nordic origin and, therefore, unlike those of their eastern neighbors. ${ }^{4}$ But Greek mythology agreed with that of the Hebrew-Chaldeans, in its creation of man by gods who were magnified human beings. If these Greek traditions are less exalted, they exhibit a human quality that finds a sympathetic response in the western mind. The Greeks were the first among the European-Mediterranean peoples to engage in critical speculation regarding the origin of the cosmos. Observing that all nature was in a state of flux, the Ionic philosophers sought for a permanent element beneath the visible change. The claim that Greek thinkers formulated a theory of organic evolution can hardly be substantiated. Their evolutionary hypotheses were vague theories of a cosmic character with such elements as water, air, earth, and fire as the underlying realities from which other visible forms came into being. Ideas of organic development were incidentally expressed as a part of this philosophical concept of the evolution of the visible world. The recognition of fossils, as the remains of animals and plants which had formerly lived, is an example of the directness of the Greek mind with its sense for natural explanations. The fossil seems to have meant nothing which implied a grasp of its significance as evidence for a general process of organic evolution. Xenophanes (c. 570-480) recognized fossils as "proofs that the seas formerly covered the earth."

${ }^{3}$ White, A. D., "A History of the Warfare of Science with Theology in Christendom," Vol. I, p. 90.

${ }^{4}$ Cf. "The White Man's Magic in Hoiner," Wright, J., Scientific Monthly, Dec., 1919. 
But his general conclusion was "that water was the element from which the earth was engendered." Empedocles, to whom has been ascribed the formulation of a theory of the Survival of the Fittest, "was an evolutionist only in so far as he taught the gradual substitution of the less by the more perfect forms of life." Perfect and imperfect forms, he believed, arose by spontaneous generation. ${ }^{5}$ Persistent belief that living beings were generated spontaneously from nonliving matter was perhaps responsible for this failure of the Greeks to pursue their speculations regarding cosmic evolution to the field of animal and plant origins.

Among the Romans, Lucretius shows comprehension of the evolutionary process in limited cases. His extended account of the human race, as originating from a condition essentially like that of the brute and advancing by gradual stages, bears a remarkable resemblance to the general conclusions of modern anthropology. Man is pictured as first a hardy animal-like race living in a wild state without agriculture and without family life. His food consisted of the natural products of the earth and of the trophies of the chase. He was without weapons save chance sticks and stones. His earliest habitations were in the form of caves and sheltered places. The association of mates gave rise to family life. Weapons and implements, huts, clothing of skins, and fire were gradually acquired. Language developed from natural cries and sounds, such as we now find animals making to one another. Music later arose. Metal succeeded stone, woven garments those of skins. Agriculture came to be practiced. Animals were domesticated. Tribal and governmental organization was slowly developed and also belief in the gods, until civilized existence had thus come into being. The whole account is a remarkable approach to the modern scientific formulation of the history of human evolution from an animal ancestry. It rested upon knowledge concerning animals and savage races of mankind which was then extant, ${ }^{5}$ Osborn, H. F., "From the Greeks to Darwin," pp. 36-40. 
and is an illustration of the fact that clues to a rationalistic explanation of human origins were in existence even at this early period. ${ }^{6}$

Naturally enough, these beginnings of evolutionary thought found no supporters during the Middle Ages. Their obliteration was an incident of the decline of Greco-Roman science which has been described in an earlier chapter. Christian theology, through its amplification of the Hebrew story of Creation, furnished an explanation of the origin of man and the universe that was accepted as satisfactory until the Copernican system had displaced the older astronomy and the sphericity of the earth had become a matter of common knowledge. From the decline of Greek speculative thought until the middle of the eighteenth century, there was no real grappling with the problem of the historical origin of organic beings. Occasionally during the later centuries of this period there were individuals, like Leonardo da Vinci, who recognized the lapse of time involved in geological change and who understood the nature of fossils. ${ }^{7}$ The Middle Ages stand for the same stagnation here, as in other lines of scientific thought. Only, the concept of organic evolution was longer delayed than any other scientific generalization of equal importance.

Organic evolution appears in its proper setting, if we realize that biological science has but recently passed through a period of battle comparable to that through which astronomical science passed in the period after Copernicus, and geographical science following Columbus. The evolu-

${ }^{8}$ Lucretius, "De Rerum Natura," Book V. Translation by H. J. A. Munro, entitled: "Lucretius on the Nature of Things."

${ }^{7}$ Some of the medieval writings show that fossils were well enough known to demand explanation. For example, these semblances of animal and plant life were said to be caused by "fatty inatter set into fermentation by heat"; by "lapidific juice"; by "the tumultuous movement of terrestrial particles." Or they were regarded as: "sports of nature"; as "mineral concretions"; as "creations of plastic force"; as "models," made by the Creator before he decided upon the final forms of creation; or as the bones of animals which had perished in the Noachian deluge. White, A. D., loc. cit. 
tionary concept is as fundamental in biology as the heliocentric theory in astronomy or the theory of the earth's sphericity in geography. This great biological generalization was not established before the close of the Renaissance, mainly because it was unthinkable from the standpoint of traditional cosmogony and because its demonstration depended upon so wide a range of facts. The older idea of the structure of the heavens had passed away by the end of the seventeenth century. But there did not seem to be adequate reason for doubting the scriptural account of the origin of the universe. The Mosaic account was still accepted despite the difficulties which now began to be recognized. The case is not dissimilar from what occurred in the nineteenth century when attempts were made, to exclude man from his place in the animal world, by the anti-evolutionists.

\section{THE TRANSMUTATIONISTS OF THE EIGHTEENTH CENTURY}

The first scientific formulation of organic evolution occurred toward the middle of the eighteenth century. The biological contribution of the Renaissance had consisted of the progressive increase of knowledge in natural history. During the fifteenth, sixteenth, and seventeenth centuries, knowledge concerning the number and kinds of animals and plants and their distribution was acquired. By the opening of the eighteenth century the question of their origin had begun to demand something more than formal explanation. The very number of different kinds of animals made it difficult to understand how all could have been named by Adam or how the progenitors of so many kinds could have been contained within the ark of Noah. Moreover, the problems of geographical distribution were being acknowledged. The animals found upon oceanic islands presented puzzling questions, which were at first explained on the theory that the ancestors of these animals had been transported thither by man. But men came to doubt the possi- 
bility of the transportation of ferocious beasts on long and arduous voyages; while the voluntary transference of animals, which were positive pests, seemed highly improbable. The Mosaic account of creation and the story of the Noachian deluge became increasingly difficult to believe in view of the facts. But there was, as yet, no alternative explanation.

The classification of animals and plants, accomplished by Linnæus (1704-1778) during the eighteenth century, gave additional emphasis to the facts which had produced these difficulties. Increasing knowledge of anatomy, of embryology, of heredity, and of variation gave clues for the formulation of a theory of organic evolution on a scientific foundation. To George Louis Lecler, Comte de Buffon (17071788), more than to any other individual, belongs the credit of having formulated this first scientific theory of organic evolution. Buffon clearly expresses the idea that particular types, like the vertebrates, the molluses, and so forth may have descended from a common ancestry. He even goes so far as to suggest that all living things may have arisen from an identical source. Had he not lived in an atmosphere of orthodox tradition, Buffon might have gone much further than he did. His phraseology is guarded and often selfcontradictory, but his meaning is clear. That his fears of persecution were not unfounded is seen by the fact that he was forced to recant (1751) by the faculty of the Sorbonne at Paris. ${ }^{8}$

During the latter half of the eighteenth century there were many other advocates of this new doctrine of descent with modification. These men were called Transmutation-

${ }^{8}$ Buffon's printed recantation is as follows: "I declare that I had no intention to contradict the text of scripture; that I believe most firmly all therein related about the creation, both as to order and as to order of time and matter of fact, I abandon everything in my book respecting the formation of the earth, and generally all which may be contrary to the narrative of Moses." Quoted from: Clodd, E., "Pioneers of Evolution," p. 96. Buffon may be accused of indirectness, but evidently his meaning did not escape the vigilance of conservatism. 
ists, because they maintained the transmutability of species. We have already commented upon this first century of the modern scientific period as a time when innovations were in the air. The theory of transmutation, and also certain evolutionary concepts in geology, were advanced by Buffon, on the basis of the first-hand knowledge set forth in his monumental work upon natural history. Buffon was not widely supported by his scientific colleagues, but another Frenchman, Pierre de Maupertuis (1698-1759), a philosopher rather than a scientist, exhibits "a wider intellectual horizon than was common among the men of science of his time." For example, Maupertuis examined critically the theory of preformation, which then dominated embryological science, and found it wanting. He set forth a remarkable theory of epigenesis. ${ }^{9}$ He apprehended certain important features in the problem of individual development at a time when this matter had received scant consideration. Examination of the problems of embryology led him to consider those of heredity and variation. As a result he came to regard the transmutability of species as a far more reasonable belief than their fixity. He conceived the gradual accumulation and the transmission of variations, carried on for countless generations to be sufficient to produce all existing species from a single original pair. ${ }^{10}$ Unlike Buffon, Maupertuis was not primarily a contributor to scientific knowledge. But he possessed an insight into the meaning of current facts which was in advance of the understanding shown by the vast majority of his scientific contemporaries.

A similar appreciation of meanings appears in the writings of Denis Diderot (1713-1784). Although he was even less

${ }^{9}$ The modern concept of development as a combination of preformation and epigenesis is explained on p. 193 of the present volume. It is worth noting that Maupertuis published his theory of epigenesis more than a decade before the modern scientific formulation of this doctrine which appeared in the "Theoria Generationis," by Kaspar Wolff in $\mathbf{1 7 5 9}$.

${ }^{10}$ Lovejoy, A. O., "Some Eighteenth Century Evolutionists," Popular Science Monthly, July, 1904. 
of a scientist than Maupertuis, Diderot recognized the evolutionary significance of the details of anatomy that were being factually set forth by the great Daubenton (17161800). The latter appears to have been oblivious of the larger interpretations. Although he was the great pioneer in the field of vertebrate anatomy, it was not Daubenton, the scientist, but Diderot the philosopher, who saw the meaning of the facts in relation to the mutability of species. A vast array of anatomical data, which are now regarded as one of the strongest lines of evidence for evolution, was becoming discernible. Its meaning was appreciated by a few individuals before the middle of the eighteenth century. The decade following 1745 witnessed the setting forth, by Diderot and Maupertuis, of two of the most important lines of evidence for descent-anatomy and inheritance with variation, and also the publication of the first volume of Buffon's "Histoire Naturelle" (1749). "The appearance of modern evolutionism, as a theory definitely formulated and based upon its proper embryological and anatomical premises," therefore, dates from the middle of the eighteenth century."

Throughout the latter half of the eighteenth century, the theory of the transmutation of species was a frequent topic

${ }^{11}$ In the paper by Professor Lovejoy, loc. cit., the opinions of two other eighteenth century writers are given at length-Johann Gottfried von Herder (1744-1803), and James Burnett, Lord Monboddo (1714-1799). The former has been greatly overrated as an early advocate of the transmutation hypothesis. It is by no means clear, according to Lovejoy, "that he did not intend explicitly to repudiate it." Monboddo, on the other hand, although he cannot be taken very seriously as a zoölogist, "was perhaps the first to make widcly familiar to the British public the doctrine that man is descended from ape-like ancestors." His associates were such men as David Hume, Adam Smith and James Hutton. "In this society, so distinguished for its scientific attainments and for original theories in natural science and philosophy, Monboddo had the reputation of being one of the most learned and most original," although it was felt by most of his British contemporaries "that he pushed originality in theorizing to the point of fantastic absurdity when he declared that civilized man is akin to the orang-outang and a descendant of progenitors that lacked speech and possibly had tails." "It is a pity," said Dr. Johnson, "to see Lord Monboddo publish such notions as he has done; a man of sense and of so much elegant learning." 
of conversation in intellectual circles, particularly on the continent. In England, the subject was not widely considered until it was set forth at length in the "Zoonomia" of Erasmus Darwin (1794). In France, the studies, upon which Lamarck was to base his theory of the causes of evolutionary modification, were already well advanced before the close of the century. As we have seen, the closing decades of the eighteenth century witnessed a remarkable extension of fundamental concepts in many scientific lines. Notable among them is this greatest of biological theories.

These early evolutionists have not received sufficient credit, because the concept of organic evolution suffered a decline during the early decades of the nineteenth century and was not generally accepted until after the appearance of Darwin's "Origin of Species." The fact that, as a group, the transmutationists were not orthodox scientists is probably in part responsible for their neglect and for a certain patronizing attitude toward men like Maupertuis and Diderot on the part of nineteenth century commentators on the history of evolutionary speculation. There has been too much inclination to believe that serious evolutionary thought began with Darwin. As a matter of fact, the state of scientific opinion, during the nineteenth century prior to 1859 , is not creditable to the scientific workers in biological lines. Instead of the open-mindedness, on which scientists pride themselves, we see the men of science adhering to traditional interpretations and blind to the meaning of their own facts, while some of the supposedly inferior philosophers were alive to the significance of the facts discovered by the scientists. The explanation, which suggests itself, is that the mind which is most capable, in the accumulation of details, is frequently lacking in the appreciation of larger meanings. At certain times in the history of science, the systematic mind has prevailed and at others the mind which grasps at meanings. Only the exceptional individual, such as Darwin, combines the two. When lesser minds run to theorizing, as 
in the post-Darwinian period of the nineteenth century, they fail to produce results. When systematic minds of a high order reach new territory they often miss the significance of facts to an amazing degree, as was the case with Daubenton the anatomist and Linnæus the classifier.

The weakness of the pseudo-philosopher, who dabbles in science, is that his theories always tend to outrun his facts. But this is soon corrected. In the case under discussion it is ungenerous for the biologist not to acknowledge the insight of these eighteenth century savants. For despite their dilettantism, they perceived what the majority of the technical scientific workers did not recognize until a century later. One of the myths of the history of biology is the tradition that the evolutionary doctrine was not definitely formulated, for lack of facts, until about the middle of the nineteenth century. This is not a fair historical statement and it does grave injustice to those thinker's of the preceding century, who saw the meaning of biological facts at a time when the majority of naturalists were blind. It was blindness, rather than scientific caution that caused the scientific formulation of the evolutionary theory to be rejected for more than a century.

\section{THE LAMARCKIAN THEORY OF THE CAUSES OF EVOLUTION}

Not only was the earliest scientific formulation of the theory of organic evolution made during the eighteenth century, but the same century produced, in the Lamarckian Hypothesis, a theory of the causes of evolution. Even if this theory has scant support at the present day, its promulgation is indicative of the extent to which evolutionism had developed by the opening years of the nineteenth century. ${ }^{12}$

12 The date of the first publication of Lamarck's "Philosophie Zoölogique" was 1809 , and other publications, containing references to the problem of organic evolution appeared during the first fifteen years of the century. But in view of the fact that the first decade of the nineteenth century was intellectually a continuation of the eighteenth century period, the work of 
The ideas of Jean Baptiste, Chevalier de Lamarck (17441829) were a natural development from the evolutionary concepts of Buffon. Lamarck was primarily a man of science rather than a philosopher. He is usually regarded as the founder of modern invertebrate anatomy. However much one may be disinclined to accept the Lamarckian doctrine, its originator was an active investigator. $\mathrm{He}$ is, therefore, not open to the charge of having been a speculative philosopher rather than a scientist.

Historically, the importance of the Lamarckian hypothesis is found in the fact that it was the first comprehensive formulation of the causes of the evolutionary process. Lamarck accepted evolution as an historical fact. He proposed his theory of the inherited effects of use and disuse and of the environment, as an explanation of the causes of evolution. ${ }^{13}$

The gist of the Lamarckian theory is that the individual is modified by the use and the disuse of its parts and that these modifications are transmitted to its descendants. The case is similar with the effects of the environment. An animal which runs develops the parts involved. It runs faster with practice and it has stronger and larger muscles after many repetitions of this activity, just as does the athlete who has undergone prolonged training. The adage "practice makes

Lamarck was a product more distinctive of the eighteenth than of the nineteenth century. Lamarck's ideas represent the climax of the transmutationist doctrines. Moreover, the more active working years of his life (1744-1829) fall within the eighteenth century.

${ }^{13}$ Therc exists in non-scientific circles at the present day a confusion between evolution as an historical process and the causes which have produced evolution. This is frequently seen in the confusion between the Darwinian theory of Natural Selection, which is a theory of the causes of evolution, and the more comprehensive doctrine of organic evolution. The historical fact of evolution is as distinct from its causes as the historical fact of the colonization of the western hemisphere by Europeans is distinct from the causes which have induced so many people to leave Europe during the past four hundred years. The fact that the Americas were thus settled is beyond reasonable question. The causes of this migration westward of Frenchmen and Englishmen and Spaniards and later Germans, Irish, Italians, and the like are a different matter and one concerning which there exist divergences of opinion. 
perfect" describes the situation and no one disputes the claim that such changes do occur in the individual. The converse, of the disuse of a part, is no less familiar. The man of sedentary life is painfully aware of the reduced capacity of his little used muscles after a day of unusual exercise. The religious fanatics of certain countries, by the voluntary and persistent disuse of a limb, bring about not only a loss of function in the part but its permanent reduction in size. In animals under experimentation, similar atrophies can be produced. Changes are also induced in the individual by environment. A mammal taken into a cold climate is stimulated to lay on fat or produce longer hair. An insect may be modified in color by a change in the water-content of the atmosphere. The lowland tree, when growing upon a mountain, is modified in a manner peculiar to the new environment. The human skin is tanned by the sun, hence the white man, after long residence in the tropics, may never recover his whiteness of face and hand, even though he returns to his northern home.

Many examples of the effects of use and disuse and of environment will occur to the reader. Animals and plants under experimentation give similar results. There can be no question regarding the effects produced by these Lamarckian factors of use, disuse, and environment upon the individual. New characteristics are thus acquired by the individual; and the phrase acquired characteristics has become a technical term in biology, having this restricted meaning.

Thus far, we have spoken only of the individual animal or plant, which is itself changed by the action of these Lamarckian factors. But the crux of the theory is its claim that characteristics, thus acquired by the individual, are inherited by the next generation. It is for this reason that the Lamarckian hypothesis may be described as the theory of inheritance of acquired characteristics, using the words acquired characteristics in the sense above explained. Lamarck believed that the changes so produced in animals and 
plants in a given generation were inherited in the next; that if an animal used the same parts in the same way, generation after generation, or if it failed to use them, the results were cumulative. Each generation added a little and this was passed on to its offspring. Thus bit by bit the modification was carried to an extreme degree. Lamarck's own formulation of his doctrine was complicated by mystical ideas about the animal's willing to do or to be certain things. But its essential claim was that effects produced by use, disuse, and environment were inherited by the next generation. ${ }^{14}$

The Lamarckian theory of the causes of evolution was not widely accepted at the time of its promulgation for the same reason that the entire theory of transmutation was rejected. The opponents of the Lamarckian doctrine criticized not only the proposed causes but also the claim that evolution had occurred. The Lamarckian hypothesis of evolutionary causation has survived to the present day and still finds support from those who are called the NeoLamarckians. But it has never been widely accepted. Of late years the failure to obtain conclusive evidence for the inheritance of characteristics acquired by the individual has told heavily against the theory. It would seem that if such inheritance occurs we should by now have secured experimental proof. Convincing proofs have not been forth. coming. The majority of biologists, therefore, regard the Lamarckian Theory as distinctly not proved. Many go

${ }^{14}$ Some of the specific cases which Lamarck cites are as follows: The webbed feet of swimming birds were produced by the animals' efforts to spread their toes in attempting to keep afloat; the legs of wading and of perching birds became long or short by their use in these peculiar fashions; snakes lost their limbs through disuse. Snails acquired tentacles by the stimulation of the anterior end of the body, as the animal crawled about and came in contact with obstacles. Lamarck's most extended statement of his doctrine appears in his "Philosophie Zoölogique." Modern advocacy of Lamarckism will be founc in: Packard, A. S., "Lamarck, His Life and Work," 1901; and Henslow, G., "The Origin of Plant Structures," 1895. An excellent, if brief, summary of Lamarckism appears in: Herbert, S., "First Principles of Evolution," pp. 111116. 
so far as to believe there is small chance of it ever being proved. ${ }^{15}$

Even if the Lamarckian hypothesis should be substantiated by satisfactory experimental proof, there still remain certain features of animal organization which are not readily explicable in terms of this theory. For example: The resemblance of many animals to their surroundings is so striking that it is commonly regarded as a means of protection from enemies and hence of life and death importance. The importance attached by Darwin to such adaptive features of animal life led to their over-emphasis during the post-Darwinian period. It is undoubtedly true that many of the supposed examples of this form of adaptation are imaginary. The reaction against the assumption that almost every structure and every action of a living thing was adaptive went to the opposite extreme, and at the close of the nineteenth century some biologists seemed to regard the whole phenomenon of adaptation as a myth. When, however, due allowance is made for the over-emphasis of adaptation, when it is frankly acknowledged that animals may have many features which are non-adaptive if not positively harmful, and when we understand that it is the all-round ability to meet the necessities of existence rather than a few particular tests, which constitutes survival value, the fact remains that a certain quality of fitness is one of the most widespread features among living things. We cannot explain this fact by denying its existence. Resemblance to the environment is a fact in many cases. After making every allowance, there remain many instances which can be explained most reasonably on the assumption that resemblance to the surroundings is an important means of protection.

15 The recent work of Guyer and Smith, who seem to have induced the inheritance of eye defects in rabbits, is of the greatest interest; but confirmation and more extended experimentation is needed before the results can be regarded as conchusive. Jour. Exp. Zool., Vol. 31, No. 2, 1920. 
Granting the existence of such adaptative resemblance, its mode of origin is something to be explained by any comprehensive theory of the causes of evolution. The Lamarckian theory does not seem to give a satisfactory explanation. One cannot easily imagine how an animal by its actions can cause the color or the shape of its body to look like its surroundings. It might remain quiet and arrange the parts of its body in certain positions. But to suppose that it can, by use or disuse, make its body look like its background seems absurd. Neither can one imagine how the environment can cause an animal to resemble the background, save in simple cases like that of the caterpillar which is green because the green of the leaves devoured as food shows through its semi-transparent body. The Darwinian theory of natural selection, on the other hand, offers a satisfactory theoretical explanation of how such fitness may have arisen. Against the substantiation of the Lamarckian hypothesis as a whole, there exists, moreover, a body of embryological evidence, obtained during recent years, and supporting the belief that the mechanism of inheritance is through the germ-cells and not through the body. ${ }^{16}$

The most notable supporter of Lamarck, during the early decades of the nineteenth century, was Etienne Geoffroy Saint-Hilaire (1772-1844). St. Hilaire emphasized the effects of the environment, while Lamarck had emphasized use and disuse. The Lamarckian theory, as we speak of it here, includes all of these factors. In 1830, the year following the death of Lamarck, ${ }^{17}$ a notable scientific debate took place between Cuvier, who was then regarded as the foremost living zoölogist, and St. Hilaire concerning the doctrine of transmutation. The superior acumen and the greater

${ }^{16}$ The volume "Heredity and Environment," by E. G. Conklin, contains an excellent statement of this modern interpretation of the part played by the germ-cells in heredity.

${ }^{17}$ In the later years of his life, Lamarck became blind and lived as a pathetic figure, his theories ridiculed by most of his contemporaries and himself in straightened circumstances. 
knowledge of Cuvier won the day. Transmutation was seemingly disposed of in the scientific world and the Lamarckian doctrines seemed at an end. But almost immediately afterward came the publication of the first edition of Charles Lyell's "Principles of Geology" (1830). In this the theory of geologic evolution was formulated as the only reasonable explanation of the changes which have given the surface of the earth its present form. The year following, Charles Darwin set out on the voyage around the world which was destined to become so decisive a factor in his subsequent work upon the origin of species. The "coming of evolution" was at hand even when its precursors seemed discredited as in the case of Lamarck.

\section{THE DARIVINIAN THEORY}

There were other reasons for the initial failure of scientific evolutionism. But the fundamental reason was the inertia of the human mind when confronted with an interpretation of nature which differs widely from established tradition. Belief in special creation and an unscientific attitude toward the larger problems of nature had dominated thought for almost two thousand years. It was natural, therefore, that the first scientific theories of evolution should end in failure. Nevertheless, this failure was apparent rather than real.

During the early decades of the nineteenth century the great Cuvier (1769-1832) continued the work of Daubenton and established the science of Comparative Anatomy. Karl Ernst von Baer (1792-1876) followed, establishing Comparative Embryology during the second quarter of the century. Geological science had received its initial impulse during the eighteenth century through the work of James Hutton (1726-1797), whose "Theory of the Earth" (1795) maintained that the past history of our planet was explicable in terms of changes observable in the present. In the main, 
Hutton's ideas of volcanic action, of weathering, erosion, deposition, and uplift were those which have been elaborated by modern geology. His point of view was in every respect scientific. His work constituted the foundation of British geology. Hutton was followed by William Smith (17691839) who is called the "Father of English Geology." The latter showed, in his "Strata as Identified by Organized Fossils," that the layers of the sedimentary rocks may be

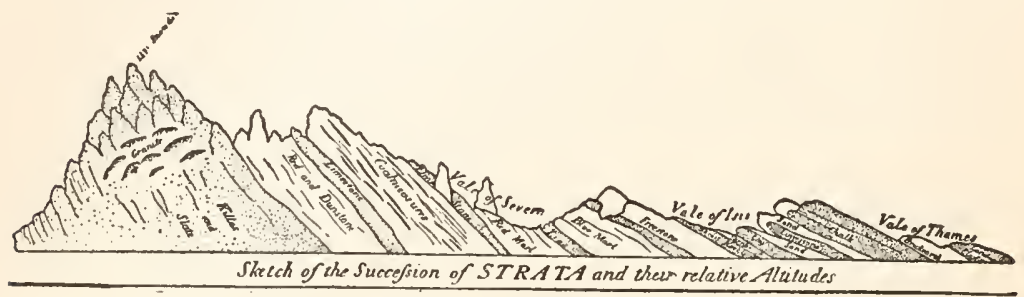

FIG. 23. William Smith's Geological Section across the South of England. Exaggeration of the vertical scale makes the beds appear too steep. The original drawing was in colors. (From Scott, "Land Mammals of Western Hemisphere," published by the Macmillan Co. Reprinted by permission.)

identified by their fossils. This principle, which Smith applied in his geological sections across England (Fig. 23) has since been extended by geologists, until the correlation of the sedimentary rocks on different continents has been effected by extended applications of the methods he laid down.

During the early years of the nineteenth century, the theory of creation, as applied to the earth's surface, was changed into what was known as the Theory of Catastrophism. According to this theory, the earth was supposed to have evolved through a series of creations, between each of which life flourished until destroyed by a great catastrophy which was the prelude to a new creation. The catastrophism hypothesis was developed to meet two facts that were irreconcilable with the theory of a single creation:the discovery that animals of the past were unlike those of the present; and the discovery that the dissimilarity in- 
creased as the record was followed backward in time. Conversely, the fossils of more recent time were in many cases almost identical with existing forms. Evidences of violent geological disturbances were taken to mean that great catastrophies or cataclysms had occurred. By supposing that such cataclysms had destroyed all life and made necessary a new creation, it was possible to save the creation theory, since the creation described in Genesis could then be regarded as but the last of a series. The Day of Judgment was the cataclysm which would bring the present epoch to an end. Catastrophism was a step forward, in so far as it acknowledged facts of palæontology, which were then well established, and emphasized the study of natural forces after the manner which Hutton had laid down.

Cuvier was the most forceful advocate of catastrophism. His studies upon fossil animals forced him to recognize the progressive sequence of the record, which is now regarded as one of the strongest pieces of evidence for organic evolution. But he approached the subject with preconceived notions that were an inheritance from medieval cosmogony. $\mathrm{He}$ was, therefore, opposed to the theory of descent. Eventually the facts of anatomy which he established became important evidence for evolution.

While the acceptance of organic evolution was thus delayed, the evolutionary principle was established in geological science by the work of Charles Lyell (1797-1875). Lyell was not at first a believer in organic evolution, but was converted to this view by Darwin's "Origin of Species." His "Principles of Geology" (1830) was widely lead and studied. It maintained its place as an authoritative reference work until the last quarter of the nineteenth century. The significance of this book is found in the fact that it attempted to explain the past in terms of the present after the manner characteristic of modern geology. Its sub-title, "An Attempt to Explain the Former Changes of the Earth's Surface by Reference to Causes now in Operation," indicates the manner 
of attack. It gave the final blow to the doctrine of catastrophism by showing that there had been no catastrophies. Great changes had occurred, but they had been orderly even when they were most violent. Unconformity in the layers was as much the result of orderly change as was conformity.

Lyell's position as a Uniformitarian in Geology ${ }^{18}$ inclined him to disbelieve the theory of the transmutation of species. He offered what was the final convincing proof of geologic evolution as the historical process by which the crust of the earth had assumed its present form, and he firmly established the Huttonian doctrine of interpreting the geologic past by means of the present. We have seen that the feature of progression in the fossil record had necessitated modification of the idea of a single creation. But with the overthrow of catastrophism by uniformitarianism, the evidence for progression was temporarily ignored. Belief that geologic forces had been constant was conducive to belief in the constancy of species. Even Lyell did not acknowledge facts, which were evident in his time and have since become cardinal features in palæontology, until they were convincingly stated by Charles Darwin in the "Origin of Species."

The period between 1830 and 1859 has been commonly represented, by the historians of organic evolution, as one in which biological science hesitated to accept the evolutionary hypothesis because of lack of evidence. The acceptance of evolution, which followed the appearance of the "Origin of Species," seems dramatic, because the impression has been

18 The "Uniformitarians" opposed the "Catastrophists," pushing Hutton's doctrines to an extreme, by arguing that the action of geological agencies in the past had been so uniform as to preclude anything widely different from the present. "They were inclined to disbelieve that the stratified formations of the earth's crust furnish conclusive evidence of a gradual progression, from the simplest types of life in the oldest strata to the most highly developed in the youngest; and saw no reason why remains of the higher vertebrates should not be met with among the Palæozoic formations." Geikie, Archibald, Enc. Brit., Article on Geology. 
fostered that scientific evolutionism was a new idea as late as the middle decades of the nineteenth century. Among English-speaking naturalists, however, "the theory was a commonplace topic of discussion for two or three decades before 1859, and especially after the publication and immense circulation of Robert Chamber's "Vestiges of Creation," of which the first edition appeared in 1844. Geological textbooks of the period referred to the theory of transmutation of species as a matter of course, though usually only to reject it as an exploded hypothesis. ${ }^{19}$ It is an interesting fact in the history of thought that a more glaring obtuseness is exhibited by the scientific mind, during these decades before the "Origin," than was exhibited by the naturalists of the eighteenth century who saw nothing of significance in the evidence for evolution set forth by Buffon and his contemporaries. It was Chambers, the literary man and amateur naturalist, who saw that which Darwin had already seen, but that to which the majority of technical workers were still blind.

It is much to the credit of Herbert Spencer (1820-1903) that he accepted unreservedly the doctrine of organic evolution, as shown by an early article of his upon the "Development Hypothesis." 20 In this he supports the despised Lamarck-

${ }^{19}$ Lovejoy, A. O., "The Argument for Organic Evolution before the "Origin of Species," Popular Science Monthly, Nov., 1909.

${ }^{20}$ In this article, which was published in a newspaper, called the Leader, March 20th, 1852, Spencer writes as follows: "Those who cavalierly reject the Theory of Evolution, as not adequately supported by facts, seem quite to forget that their own theory is supported by no facts at all. Like the majority of men who are born to a given belief, they demand the most rigorous proof of any adverse belief, but assume that their own needs none. Here we find, scattered over the globe, vegetable and animal organisms numbering, of the one kind (according to Humboldt) some 320,000 species, and of the other, some $2,000,000$ species (see Carpenter); and if to these we add the numbers of animal and vegetable species that have become extinct, we may safely estimate the number of species that have existed, and are existing, on the earth, at not less than ten millions. Well, which is the most rational theory about these ten millions of species? Is it most likely that there have been ten millions of special creations? Or is it most likely that by continual modifications, due to 
ian theory as the cause of evolution, a fact which probably rendered his views on the broader question of descent less palatable to his countrymen. In his later writings, Spencer was primarily a philosopher, and this may account in part for the scant acknowledgment he has been given by scientists as compared with Darwin. Nevertheless he occupies an important place in any critical history of the doctrine of evolution, because of his early conviction that such a theory was the only reasonable interpretation which could be placed upon the facts, as well as on account of his thoroughly scientific viewpoint.

The foregoing discussion serves as an introduction to the work of Charles Darwin (1809-1882). Darwin deserves the place he occupies, because he combined the grasp of the philosopher with the accuracy of the scientist. While still a young man on the Voyage of the Beagle (1831-1836), he perceived the significance of biological and geological phenomena which he later used as evidence for organic evolution. So impressed was he by what he had seen, in parts of the world where nature had been little changed by man, that after his return he began the studies which culminated twenty years later in his "Origin of Species" (1859). The simultaneous announcement by Darwin and Wallace, of the theory of Natural Selection is a familiar story. ${ }^{21}$ In the summer of 1858, Darwin received a letter from his fellow naturalist, Alfred Russel Wallace, who was then in the Malay archipelago, asking Darwin to present on his behalf a theory of the origin of species that Wallace had outlined. The conclusions set forth in this brief communication were

change of circumstances, ten millions of varieties have been produced, as varieties are being produced still?"

${ }^{21}$ The two brief papers were published in the Journal of the Proceeding of the Linnean Society, 1858, p. 45. Apparently, they made little impression, for Darwin tells us in his autobiography that the only published notice he remembered was to the effect "that all that was new in them was false and what was true was old." Reprints of these papers will be found in the Popular Science Monthly, Nov., 1901. 
identical with those which had been reached by Darwin after years of study. But so great was Darwin's generosity and modesty that his first impulse was to publish Wallace's views without any mention of his own work. Fortunately, Lyell, and Hooker, the botanist, both of whom knew the history of Darwin's work, persuaded him to announce the results of his own studies in a similar formulation. This he consented to do and was also persuaded to prepare the more extended statement which appeared a year later as the "Origin of Species." 22

The publication of this work marked the beginning of a new epoch, both in biological science and human thought. The origin of the human species was only suggested, its discussion being reserved for a later volume, the "Descent of Man" (1871). The dramatic features attendant upon the publication and promulgation of Darwin's views are well known. In 1900, the "Origin" was rated as of ne of the half dozen books of the century in the number of copies printed. What is less well understood, even at the present day, is the exact nature of Darwin's scientific accomplishment and its significance in the history of human thought.

Darwin's work accomplished two things in biological science:-in the first place, it established organic evolution as the only reasonable explanation of the past history of living things; and secondly, it offered, in natural selection, what then appeared an adequate explanation for the origin of species and hence for the causes of evolution. Darwin's essential argument in the "Origin of Species" was that one species could give rise to another "by means of natural selection or the preservation of favored races in the struggle

${ }_{22}$ The cordial relations which existed between Darwin and Wallace and the generosity exhibited by both is one of the cherished traditions of biological science. The case might have been very different, since there was abundant opportunity for professional jealousy. Because of their mutual generosity, history accords to Darwin and Wallace a joint position as discoverers of natural selection, although it recognizes the priority which should be accorded to Darwin because of his earlier and more extended studies. 
for life." If one species could be shown to give rise to another, the same process could be continued. No limit could be set. And the types thus produced could depart indefinitely from the parent form. Once the mutability of species is admitted, the only reasonable conclusion is that evolution has taken place. This argument was supported by an immense collection of facts along observational and experimental lines. The total result was overwhelming, coming as it did more than one hundred years after the original promulgation of the theory of transmutation which had been repeatedly rejected by the main body of naturalists. Evolution was accepted so quickly by scientists that the world was startled. This sudden conversion gave rise to the impression, even among scientific workers, that no serious contribution to evolutionary theory had been made before the period of Darwin.

Moreover, Darwin's second accomplishment, Natural Selection, was accepted by science as a causo-mechanical explanation of evolutionary change. The cogent statement and the simplicity of the principle of selection were of great importance for its acceptance along with the broader theory of evolution. For a time, it seemed that selection offered a complete explanation of evolutionary causation. Extended exposition of the selection process will not be attempted, because we are concerned with the general import of the theory in biological and other lines of thought. ${ }^{23}$ The tabulation, known as Wallace's Chart, which is an admirable brief exposition of natural selection, may be cited in this connection.

${ }^{23}$ Brief statements of the theory of natural selection will be found in many biological texts. But Darwin's own exposition, in the first chapters of the "Origin of Species," is not so extended but that one can consult the original source. G. J. Romanes, "Darwin and After Darwin," Vol. I, "The Darwinian Theory" (1896), represents a post-Darwinian point of view. V. L. Kellogg, "Darwinism Today," (1907) is a critical examination of the status of the Darwinian theories at the end of half a century. 


\section{WALLACE'S CHART OF NATURAL SELECTION}

PROVED FACTS
A Rapid Increase of Numbers
B Total Numbers Stationary
C Struggle for Existence
D Variation and Heredity
E Survival of the Fittest
F Change of Environment

CONSEQUENCES Struggle for Existence Survival of the Fittest

(Natural Selection)

Structural Modifications

The importance of Darwin's work in the history of scientific thought is that it convinced science of the truth of organic evolution and proposed a plausible theory of evolutionary causation. Since Darwin's time, evolution has received confirmation on every hand. It is now regarded by competent scientists as the only rational explanation of an overwhelming mass of facts. Its strength lies in the extent to which it gives meaning to so many phenomena that would be meaningless without such an hypothesis.

But the case of natural selection is far different. Of recent years, this theory of the causes of evolution has suffered a decline. No other hypothesis, however, has completely displaced it, and it remains the most satisfactory explanation of the origin of adaptations, although its allsufficiency is no longer accepted. Moreover, the initial step in evolution is the appearance of individual variations which are perpetuated by heredity, rather than the selection of variations after they have appeared. The interest of investigators has now shifted to problems of variation and heredity.

As a result of this situation, there has been much discussion among scientists regarding the adequacy of what is often referred to as the Darwinian Theory, meaning Natural Selection. In condemning selection as an inadequate explanation of the problem, biologists have often seemed to 
condemn evolution itself. It is not strange that the layman, for whom Darwinism and evolution are synonymous terms, believes that evolution has been rejected when he hears that belief in Darwinism is on the wane. He does not understand that what is thus meant by Darwinism is not evolution, but the proposed cause of evolution-natural selection. This point may not seem vital, but those interested in biological science frequently find the situation used to support claims that the entire concept of organic evolution has fallen into disrepute. There are many, even to-day, who rejoice at anything which appears to weaken this major generalization of biology.

The more important lines of evidence for organic evolution may be grouped as follows:

1. Evidence from Structure is derived from:

Comparative Anatomy

Comparative Embryology

Classification

2. Evidence from Distribution, past and present, is derived from:

Palæontology

Geographical Distribution

3. Evidence from Physiology is derived from:

Fundamental Resemblances in Vital Processes

Specific Chemical Resemblance of closely related forms, e. g., Blood Tests

4. Evidence from Experimentation rests upon:

Unconscious Experimentation upon Animals and Plants since their Domestication

Conscious Experimentation of Breeders and of Scientific Investigators

The first three of the foregoing groups consist of evidence that is wholly circumstantial. The fourth is in part experimental. The facts of comparative anatomy and embryology are what might be expected if evolution has taken place. Without evolution such facts are meaningless. Classification, since it is based on structure, is a part of this anatomical 


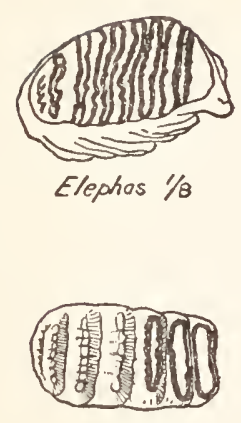

Steqodon /8

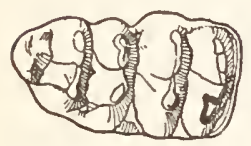

Mastodon 18

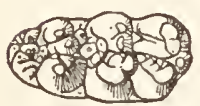

Gomphotheriun 1/8

?

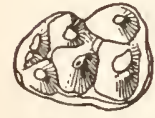

Poloeomastodon $1 / 4$

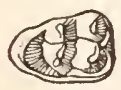

Moeritherium $1 / 4$

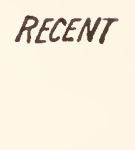

UPPER PLIOCENE)

Siegodon (shorr chin).
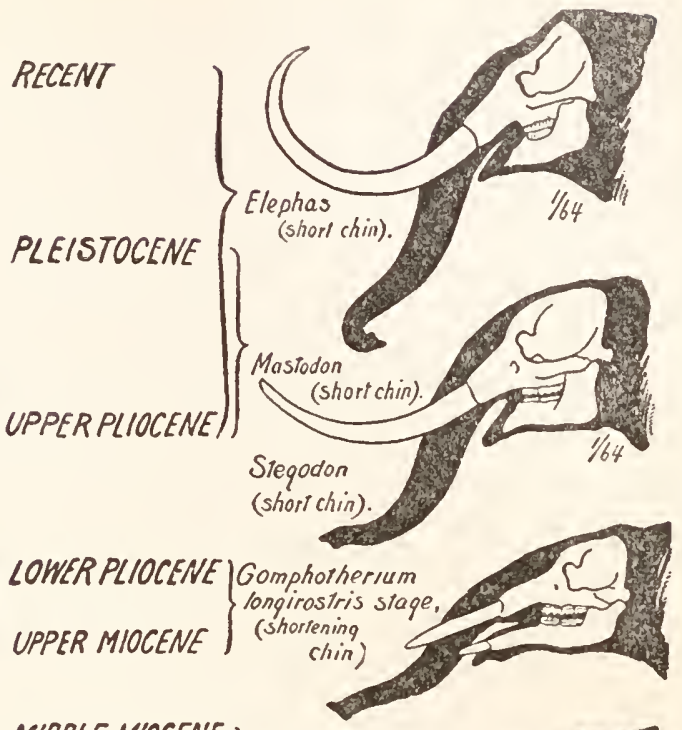

MIOOLE MIOCENE

Migration into

North America

LOWER MIOCENE

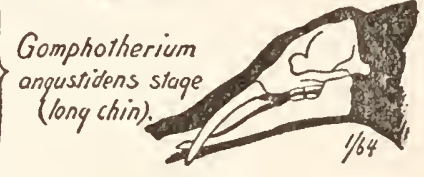

?

UPPER OLIGOCENE

?

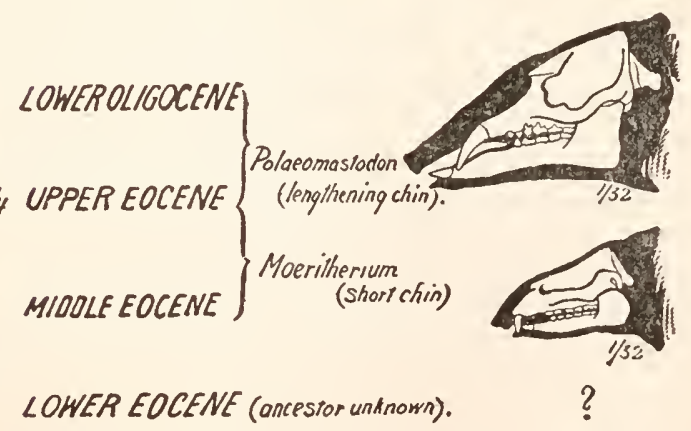

Fig. 24. Evolution of the Elephant. (From Scott, "Land Mammals of Western Hemisphere," published by the Macmillan Co. Reprinted by permission.) 
evidence. Palæontology shows a progressive appearance of higher and higher forms of life in geologic time. There are also special cases, such as the remains of the horse, elephant, and the camel, which are very convincing (Figs. 24 and 25). The present geographical distribution of animal and plant life is, in many instances, explicable by reference to their distribution at an earlier period. Innumerable facts receive a rational explanation in terms of evolution. Physiological study shows that the living substance of all animals and plants exhibits fundamental resemblances in waste, repair and growth, irritability, reproduction, and the like. Hence, all protoplasm is perhaps genetically akin. Recent work on the chemico-physical properties of blood is very impressive, because it confirms conclusions regarding relationship that have been independently derived from anatomy and embryology. In all of the foregoing, the facts are as they should be if evolution has occurred. The first three groupings are thus circumstantial evidence. But all evidence for the larger evolutionary changes must be of this nature. The strength of circumstantial evidence lies in its amount and variety, and in these respects this evidence is very strong. ${ }^{24}$

Fragmentary records of the changes in animals and plants under domestication together with scientific investigations in breeding, heredity, and variation constitute the evidence of an experimental nature. The modifications observed are small, as compared with those postulated by evolution. But the time has been short, and little more than evidence for the mutability of natural species or of domestic breeds could be expected. The significant fact is that the experimental results tell a similar story in favor of evolution. There seems to have been a certain amount of evolutionary change in our domesticated species during the past ten or fifteen

${ }^{24}$ These conventional lines of evidence are presented at length in many texts which deal with evolution. G. J. Romanes, "Darwin and after Darwin," Vol. I; S. Herbert, "First Principles of Evolution"; W. B. Scott, "Theory of Evolution," all contain excellent statements. 


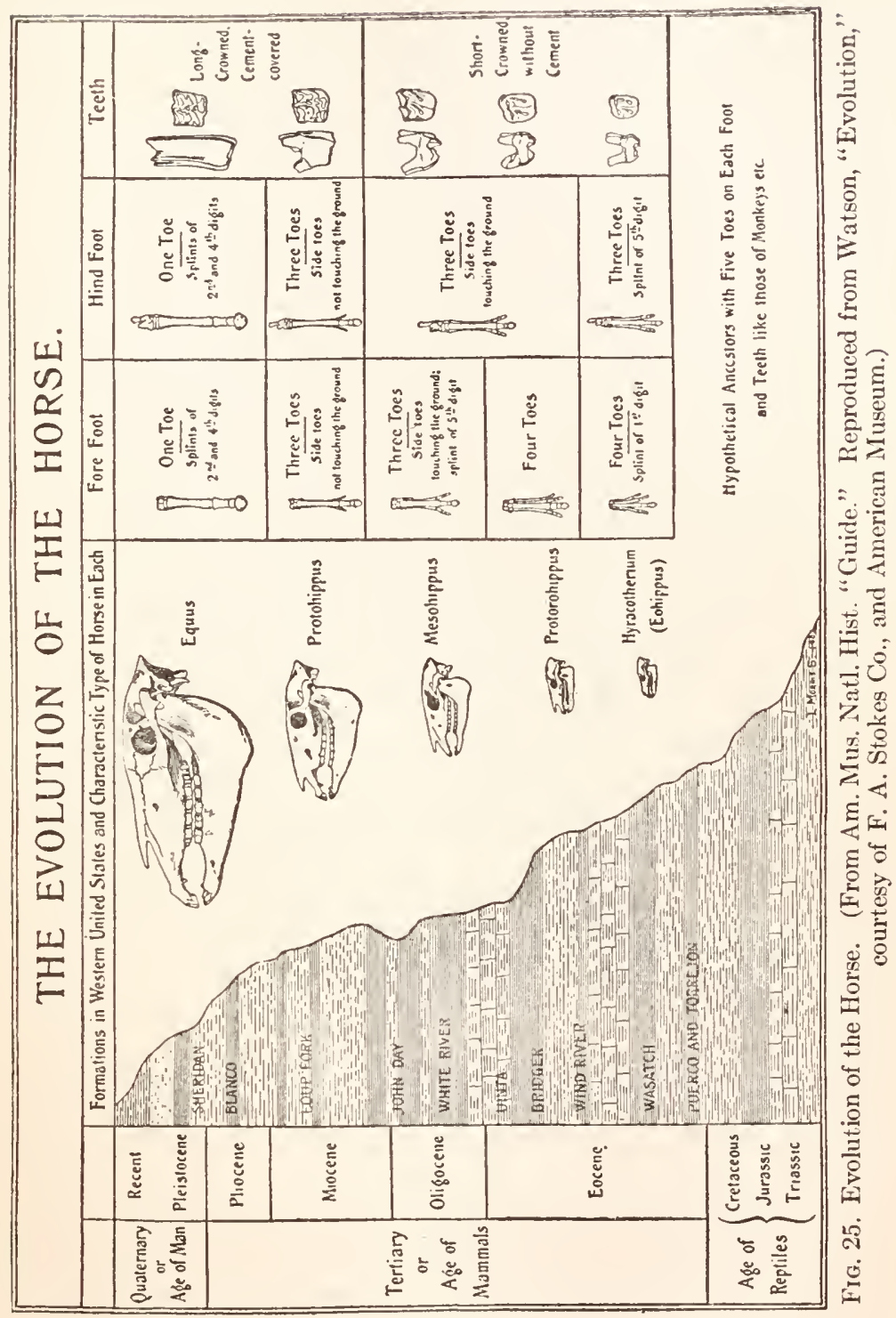


thousand years. Modern experimenters, like Darwin, Mendel, and Morgan, have thrown much light upon the workings of variation and heredity. The present situation justifies the statement that since the publication of the "Origin of Species" organic evolution has been substantiated by evidence that is now overwhelming.

The effect upon biological science of the acceptance of Darwin's conclusions was startling. Both evolution and natural selection were accepted forthwith. The biologist sought to interpret old facts in a new way and to discover new facts which confirmed the evolutionary hypothesis. In zoölogy, the study of embryology, as a means of determining racial descent, was eagerly pursued, although it eventually proved disappointing as an answer to the broader problems of relationship. However, evolution was more firmly established by means of this work. On the other hand the investigations of recent years have assigned less importance to the theory of selection. When it is understood that Darwinism may be used to mean either organic evolution or its alleged cause, natural selection, or both evolution and selection, it becomes apparent that the dispute over the efficacy of selection is not a challenging of the comprehensive theory of organic evolution.

The biological position of the evolutionary doctrine has been established. Evolution is the clue to the history of living things. But the doctrine is most important to mankind, through its influence upon human thinking outside strictly biological lines. Like the Copernican system of astronomy, it has made the universe anew within the minds of men. The concept of organic evolution has changed man's concept of his position in the order of nature. It is also changing our ideas regarding the organization of society. Lines of thought, seemingly remote from the biological field have been revolutionized. The end of this change has not come to pass. 


\section{CURRENT PROBLEMS AND METHODS OF ZOÖLOGICAL SCIENCE}

IT is sometimes said that the course of scientific progress, even the existence of entire branches of science, has been determined by a few men of genius, whose interest in particular fields has forced certain facts into prominence. As a result, science develops in some directions while it lags in others. This may possibly be true, but at times we can discern changes which appear simultaneously in the work of many individuals, affect a science as a whole, and are thus independent of any single investigator. The present generation has witnessed a change of this composite nature within the field of zoölogy. During the last three decades a transition has been accomplished from a science the methods of which were largely observational to one in which the dominating methods are experimental. No commanding personality has been involved, but rather the growing conviction of many that progress cannot be continued without more analytical methods of investigation. Proceeding to specific illustrations, we may consider some of the problems now being attacked by zoölogists, their methods of work, and the results attained. We may contrast their attitude with that of investigators during the greater part of the nineteenth century. Also, we may consider what the more analytical spirit means for this branch of science. This account of present-day zoölogy does not summarize all current investigation. The method of random sampling is applied, with a view to the selection of representative examples of zoölogical research. 


\section{PROBLEMS OF DEVELOPMENT}

Embryology:-The development of a fertilized egg into an adult animal is a marvelous phenomenon. During the nineteenth century the general course of this development was ascertained for all the major groups of the animal kingdom. The cruder misconceptions, regarding the links by which an animal is connected with its descendants and its ascendants, had been corrected before the middle of the century. The cellular basis of development was made clear during the fifty years which followed. But despite the wealth of facts discovered by the embryologists, the marvel of the developmental process has increased the more. Even in the light of recent experimentation, it must be confessed that relatively little is known regarding causation in development, aside from a knowledge of the visible changes by which the egg becomes the adult. These changes we know tolerably well. What we wish to know is why particular developmental changes occur as they do, why this or that structure arises at a particular time, and what is the relationship between internal and external phenomena. Now that the sequence of structural changes has been made known, the embryological problem has become the problem of underlying causation. In the solution of such a problem, there must be recourse to experimentation.

Fertilization illustrates the historical development of a biological problem and also the progress from nineteenth to twentieth century zoölogy. The fact that the semen of the male was in some manner necessary for conception in higher animals was known to the ancients. Aristotle wrote with remarkable acumen upon the reproduction of animals. The fact that animals of certain sorts arose from eggs was known wherever the eggs were sufficiently large to be recognizable. The eggs of birds and reptiles, and later (Redi, 1668) the eggs of smaller forms like insects were recognized as the initial stages of development, but this did not explain 
how the seminal fluid of the male was related to the generative process. After the spermatozoa and the microscopic ova of many animals were discovered in the latter part of the seventeenth century, the rôle of each was long in disputethe spermatists of the eighteenth century maintaining that the embryo arose from the sperm, the ovists that it came from the ovum. During this period a considerable amount of experimentation was carried on in the attempts to determine, by filtration and similar methods, whether the spermatozoa or the fluid portion of the semen constituted the fertilizing agent (Spallanzani, 1785).

During the first half of the nineteenth century it came to be acknowledged that the spermatozoön and not the fluid of the semen, was the activating agent. But the morphological facts of fertilization remained obscure, until, in 1875, Oscar Hertwig described correctly the cellular phenomena of fertilization in the egg of the sea-urchin. It was shown that fertilization consisted in the entrance of a single spermatozoonn into the egg, and the union of egg-nucleus with sperm-nucleus to form the nucleus of the one-cell stage from which the many-celled organism originated by celldivision. Virchow's doctrine, omnis cellula e cellula (1856), was fully confirmed; and the nature of the continuity between generations was explained in terms of the celldoctrine. ${ }^{1}$

Following 1875 there ensued a period of morphological study, during which the exact nature of cell division and the structure of the nucleus of egg and sperm-cells was ascertained. It became apparent that fertilization involved two distinct phenomena, which should be investigated independently, despite their intimate association. On the one hand were the phenomena related to the genetic problem of how egg and sperm constituted the physical basis for continuity

'Lillie, F. R., "The History of the Fertilization Problem," Science, Jan. 14, 1916, contains an authoritative summary of the history and recent status of knowledge concerning this fundamental process of reproduction. 
between generations, and on the other were those related to the physiological problem of how the spermatozoön served as an activating agent which stimulated the egg and thus caused its development. The term fertilization has latterly been restricted to the second set of phenomena-the problem of how egg and spermatozoön produce a cell capable of division.

The analysis of fertilization from its morphological standpoint, $i$. e., the structural features involved in the union of egg and sperm, prepared the way for the physiological analysis now in progress. $^{2}$ This analysis consists of (1) work upon artificial parthenogenesis, and (2) biological studies upon what may be termed the fertilization reaction between egg and sperm. The present status of the fertilization question, as a physiological rather than a morphological problem, illustrates the drift toward experimentation, which has followed upon the establishment of morphological facts, whether in embryo or adult.

But fertilization does not occur in the development of all eggs, although it is necessarily the starting point in biparental reproduction. The phenomenon of natural parthenogenesis, by which the ovum or unfertilized egg-cell develops without the entrance of a spermatozoön, occurs in a considerable number of species, among the Insecta, Crustacea, Trematoda, Rotifera, Arachnida, and perhaps the Vertebrata. ${ }^{3}$ Males are known to exist in most of these cases and fertilization of the eggs occurs in certain generations, as in the plant lice, or certain eggs are fertilized while others are not, as in the case of the honey-bee. In some cases the males are unknown, but it is presumed that they have not yet been discovered, not that they are absent. Hence, in parthenogenetic species it appears that certain eggs develop without fertilization by the spermatozoa, while other eggs are capable

${ }^{2}$ Lillie, F. R., "Problems of Fertilization," 1919.

${ }^{3}$ Phillips, E. F., "A Review of Parthenogenesis," Proc. Am. Philos. Soc., Vol. XIII, No. 174, 1903. 
of development only after fertilization like that which occurs in the great majority of animal forms.

The natural parthenogenesis above described is a comparatively rare phenomenon. Its occurrence suggests that eggs, which develop in nature only after fertilization, may be caused to develop parthenogenetically if suitable stimuli are applied. This is found to be the case; and the phenomenon is now designated artificial parthenogenesis, in contrast to the natural parthenogenesis which occurs in nature. Since the first successful experiments in artificial parthenogenesis some twenty-five years ago, ${ }^{4}$ it has been found that the eggs of many animals, among which are worms, molluscs, echinoderms, and vertebrates, may be thus caused to develop without fertilization. Development, hardly to be distinguished from that which is normal, ensues when these eggs are subjected to very dilute solutions of salts, acids, narcotics, and other substances, to changes in temperature and in some cases even to simple mechanical stimulation. It is quite conceivable that there is no egg of any animal which could not be artificially started on its development by the application of a suitable stimulus. ${ }^{5}$

Experiments such as these give an understanding of fertilization which could never be obtained by mere observation

${ }^{4}$ The first recorded attempts at artificial parthenogenesis are those of Spallanzani (1785), who attempted "to start the development of eggs by electricity, by the action of extracts of all the various organs, by vinegar, dilute alcohol, lemon juice and other substances, all without effect." Lillie, F. R., "The History of the Fertilization Problem," loc. cit.

5 As yet it has been impossible to carry through to an adult state the embryos thus formed, save in a few exceptional cases. But this could hardly be expected at the present stage of investigation, because the initiation of development, by these artificial means, is so wide a departure from the normal process. Moreover, the normally fertilized eggs of these forms are reared with difficulty in the laboratory. But there is a reasonable expectation that once the technique is discovered many artificially fertilizable eggs may be carried through their entire cycle to the adult. Should this be accomplished, it would throw light upon problems of sex and of heredity, because the adults thus formed would be without male parentage in the generation which immediately preceded them. 
of normal processes. The experimental initiation of development supports the hypothesis that spermatozoön brings to ovum a minute quantity of an unknown, but no doubt discoverable, substance which furnishes a necessary link in the chain of causation that initiates development. If a substance, isolated from the spermatozoa, could be brought in contact with eggs and thus cause them to develop, ${ }^{6}$ the stimulus to development would be recognized as a specific substance. Fertilization would then lose that intangible quality which in the past has cast a spell of mystery over so many biological phenomena. Research of this nature is now being carried forward by so many investigators that we may hope for a comprehensive understanding of this first step in development, although the facts now established have already raised unsuspected problems. ${ }^{7}$

The work upon artificial parthenogenesis has illuminated, but not explained, the process of normal fertilization. What is called the fertilization reaction between egg and sperm must be attacked by experimental work upon the normal activation of the ovum by the spermatozoön. The story of the work now in progress is too extensive to be related. As one investigator puts it, "the main physiological problems of fertilization are still before us; all the work has merely prepared the way for their solution. Fertilization is the knot in the webs of successive generations which must be untied before we can trace the strands from generation to generation." For the purposes of our present discussion, the history of the fertilization problem shows the biological

${ }^{B}$ Cf. the work of O. C. Glaser, "Fertilization and Egg-secretions," Biol. Bull., Aug. 1921.

${ }^{7}$ Considerable notoriety attached to the work upon artificial parthenogenesis when the results of the first successful experiments by J. Loeb became known. Newspaper feature stories hailed the accomplishment both as an explanation of the immaculate conception and as a creation of living protoplasm. The latter interpretation was manifestly ridiculous, since what had been done was to artificially stimulate an already living egg to develop as it would have done under normal stimulation by the spermatozoön. 
advance from an observational study of structural changes to an experimental analysis of causation.

To follow another illustration:- - one of the most famous disputes among the earlier embryologists was that of preformation versus epigenesis. Is the organism already formed within the germ, like the bud of a plant, and does development consist merely in an unfolding of what is already existent; or is development the coming into being of one feature after another from a beginning that is without form and void, in so far as any resemblance to the completed organism is concerned? The preformationists of the eighteenth century went so far as to develop an elaborate theory of encasement, by which the germ was supposed to contain all of the adult structures in miniature, including the germs of all future generations, enclosed one after another in ever-decreasing magnitude, like toy eggs within eggs carried inward to infinity. Thus, the ovary of Eve could be supposed to have contained the encapsuled representatives of all future generations of the human race.

Of course, no very extensive knowledge of embryonic stages was needed to demonstrate that the general course of development in all animals is by epigenesis and not by preformation. The fertilized egg possesses at the outset no obvious resemblance to the future adult. Adult organization is attained through growth and cell division and by gradual differentiation of parts (Fig. 12). Seemingly, there could be nothing farther from an unfolding of what is already preformed. But the fact that two eggs, placed side by side in a dish of water, develop into a frog and a toad, or into a starfish and a sea-urchin, is evidence that some sort of preformation does exist, unless one regards the development of every individual as a supernatural process which cannot be subjected to scientific analysis. Hence, the question of epigenesis as opposed to preformation has engaged the attention of experimental embryologists during recent years. The eggs of many animals, among others the frog, sea- 
urchin, and starfish, are fertilized and develop in external water without parental care. Here, experiments are possible which could hardly be made upon an egg developing within a brood-pouch or other internal cavity of a parent. The question of whether the protoplasm of the egg is preformed, to the extent that certain of its parts are destined to give rise to certain parts of the adult, has evoked considerable interest. The problem has been attacked experimentally by the removal of parts of the egg in the seaurchin and other forms. Pieces have been cut from different regions of the fertilized and the unfertilized egg; two, four, eight, and even sixteen cell stages have been separated into their component cells. These and many other experiments have been performed, with a view of demonstrating the nature of the organization, which must be postulated, since it is obviously something within the egg that determines the major features of development.

So many and so diversified have been these experiments that we can summarize only their general outcome. The eggs of many animals exhibit within their cytoplasm (Fig. 12) recognizable substances, unlike the adult parts but from which the adult parts take origin. Such eggs are thus visibly organized or preformed to the extent that certain regions of the egg become certain regions of the adult. The eggs of other animals exhibit little differentiation which can be, at present, recognized. In eggs of the latter sort, one area is more nearly of the same value as every other, and recognizable differentiation appears at a subsequent stage of development. The truth seems to be that the eggs of different animals are not alike with respect to their visible differentiation at the one cell stage; that the first signs of differentiation, while visible in some animals at the one cell stage, are less apparent in others until a later stage of development; while in those forms which have as adults great capacity for the regeneration of lost parts, the organism is never so completely differentiated as to be unable to re- 
form an entire body from a portion of the whole. ${ }^{8}$ Whether such an organization is visible or not, something of the sort must be present in every egg. Otherwise there can be no explanation of the phenomena of heredity, which can satisfy the demands of science. The embryologist is of necessity a preformationist, but not in the older sense of the word. ${ }^{9}$

In problems of this nature, satisfactory analysis can only be based upon experiments which subject the organism to new and controlled conditions. No observation of normal development, no matter how extensive, will go so far toward answering the question whether at the two cell stage the right and left portions of the animal are irrevocably distributed to right and left cells as will the simple experiment of separating these two cells and seeing what happens. In a simple way, this illustrates the whole point in the advancement of zoölogy by means of experimentation.

In addition to this study of embryonic stages, there is another method of attacking the developmental problem, which may be illustrated as follows: If one deals out the hands in a game of cards and then examines the cards in each hand, he can, if he knows the nature of the dealing, infer the manner in which the cards were arranged in the pack before the dealing began. One must assume an arrangement within the pack, which bears a causal relation to the hands or he must assume the miraculous origin of the arrangement which appears as a result of the dealing. The inference that such an organization exists within the pack before the deal begins is of the same sort as that which the chemist makes in postulating atoms and molecules which have never been seen. When one studies the inheritance of qualities appearing in an adult animal, it is like examining

"Conklin, E. G., "Heredity and Environment in the Development of Men." Wilson, E. B., "The Problem of Development," Science, Feb. 24, 1905.

${ }^{9}$ The case is analogous with that of the physicist and chemist who postulate invisible molecules and atoms, as a basis for the visible phenomena. 
the cards in the hands, while knowing something of the dealing, but not knowing the organization of the pack. If it is found that adult qualities appear in a certain manner, their probable arrangement before the dealing, that is to say the development, can be inferred.

An amazing result of the recent experimental work upon the heredity of adult characters is that the knowledge thus gained enables us to picture, without seeing, certain characteristics in the organization of the germ-cells, much as the chemist pictures the organization of molecules. There is, however, one respect in which the biologist, who seeks to understand the germ-cells has an advantage over the chemist who postulates invisible structures. There exists within the nucleus of ovum and spermatozoön, as in all other cells, a visible substance, known as chromatin and appearing at the time of cell division in the form of bodies, the chromosomes (Fig. 13), which are constant, both in number and appearance for any given species. The behavior of these chromosomes, as seen by the microscope, is so specifically related to the end results of heredity as to virtually identify them with the mechanism of transmission for certain adult qualities through the germ, and hence to suggest the probable organization of the germinal substance. ${ }^{10}$ It is thus possible to attack the problem of development at its two extremes; and, now that we understand the situation to

${ }^{10}$ Morgan, T. H., "The Mechanism of Mendelian Heredity," 1915. This volume is a current summary of conclusions reached by Professor Morgan and his students. The work, which is still in progress, has already yielded results of such importance that it is clearly the most comprehensive attack which has becn yet made upon the problem of heredity. It is important in relation to the problem of preformation, because certain postulates can now be made regarding the organization within germ-cells. If the results are sustained and extended in correlation with the work of the cytologists, a supra-molecular organization of the germ may soon be accepted in a manner comparable to the way in which the chemist accepts his working hypothesis of molecular organization. Development will then become the problem of how a germ with a given organization develops into a given adult organism-how the dealing is accomplished. 
correlate the attacks. Each supplements the other and suggests new ways of advance. ${ }^{11}$

Although the field of embryology was among the earliest to be invaded by the experimentalist in zoölogy, it is still attractive, because there is no phenomenon of nature which seems so inexplicable as the development of an adult individual from a single cell. Unfortunately, many of the organisms most desired for experimentation do not lend themselves to particular experiments. The structure of the animal and the nature of its environment impose limitations. But the investigator's ingenuity frequently surmounts difficulties which at first seem insurmountable. What impresses those who worked as students during the

${ }^{11}$ During the last quarter of the nineteenth century, August Weismann recognized the logical necessity of assuming germinal organization, in any attempt to explain the physical basis of heredity. His book entitled "The Germ-Plasin" (1893) postulated, theoretically, a germinal organization by which the mechanism of heredity and development could be depicted. The Weismannian doctrine fell into disrepute among biologists, because its author set forth the organization of the germ-plasm upon a basis which seemed far too theoretical. Biology was still under the spell of the epigenetic concept of development, as established by von Baer during the first half of the nineteenth century. The crude notions of preformation were clearly untenable and the tendency was to regard the germ-plasm as undifferentiated protoplasm. Nothing was known regarding Mendelian heredity with its implications regarding the germ. Weismannism received wide discussion but scant acceptance. But the work of the embryologists has since revealed a certain degree of organization within the egg. Simple undifferentiated protoplasm has been found to be non-existent, since all protoplasm is differentiated in some degree. Later, the facts of Mendelian heredity have forced the postulation of a complex germinal organization. To Weismann belongs the credit for recognizing the necessity of assuming a germinal organization similar, in its causal relationship to the adult organization, to that which the students of Mendelian heredity have postulated on the factual basis of inheritance of unit-characters. The ridicule which was for a time heaped upon Weismann's doctrine resembles that which attended the theory of organic evolution for many years after it had been recognized as a logical inference by the scientist-philosophers of the eighteenth century. To-day experimental embryologist and geneticist virtually acknowledge a Neo-Weismannism. The hypothetical germinal units of Weismann's theory have been replaced by the hypothetical determiners or genes of the Mendelian theory. It should be remembered that Weismann first elaborated the theory of preformation in terms of cellular biology. 
closing years of the nineteenth century, when descriptive embryology was still a dominant form of investigation, is the fact that the study of embryology has become largely experimental. The sequence of stages has been well enough established to make the more subtle causes of development the subject of investigation.

Regeneration:- The term regeneration is used to designate the process by which an animal or plant repairs the losses resulting from destruction or removal of parts. Capacity for regeneration may be small, as in the higher vertebrates which possess only the ability to heal wounds, or it may be so great that a small piece cut from the organism will reproduce the whole. The fresh-water worms known as planarians possess astonishing powers of regeneration. If the adult worm be cut in two transversely (Fig. 26), each piece becomes a complete animal. When divided lengthwise, the pieces behave in a similar manner, failing to regenerate only when too great an area of cut-surface is exposed to bacterial infection or from other untoward circumstances. In whatever way the piece may be removed, it tends to form a new individual having the characteristics of the original body, although there are some exceptions, as when heads or tails are formed in the wrong position (Fig. $26 \mathrm{D}^{1}$ )a phenomenon which is termed heteromorphosis. Even a very small piece (one investigator has estimated that a piece only $1 / 250$ of the bulk of the original can form the entire worm) is able to heal its wounded surfaces and so to change its shape and proportions that growth alone is necessary for the production of a normal individual.

In the formation of these new individuals by regeneration, we observe, in addition to a healing of the wound, a change in the relative proportions of the piece by which the normal shape is regained. This latter phenomenon is termed regulation. After it has occurred, the new individual merely grows to the original size. Another phenomenon is the polarity or determination of the axes of symmetry. No 

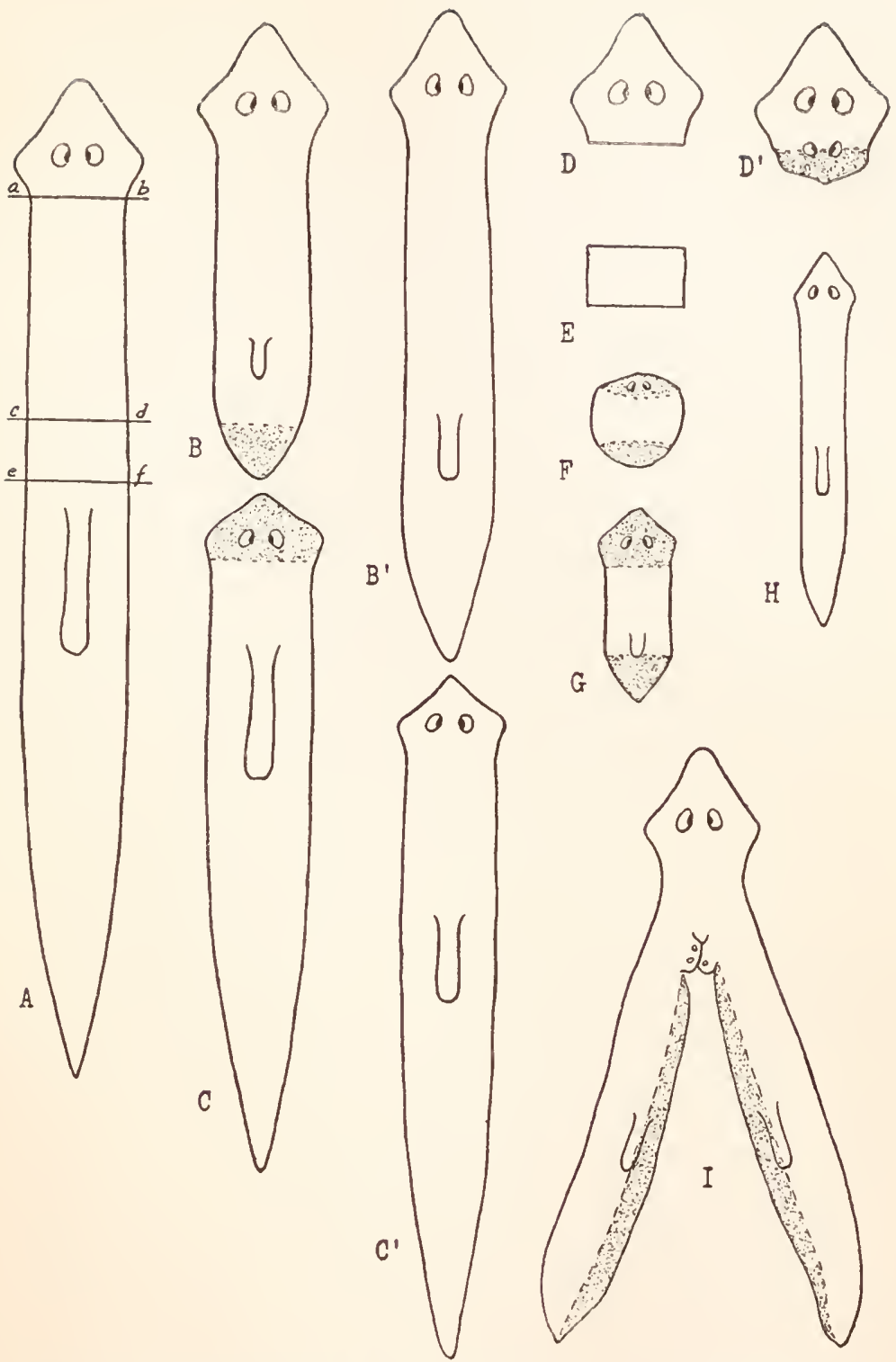

Fig. 26. Regeneration in Planarians. A, Planaria maculata, normal adult proportions; $B$ and $C$, individuals regenerating after cutting a worm in two at $e f$ in $\mathbf{A}$, scar tissue shown by stippled areas; $B^{\prime}$ and $C,^{\prime}$ the same assuming normal proportions; $D$ and $D^{\prime}$, hetereomorphosis in a piece cut from anterior end, $a b$ in $A$. $E, F, G$, and $H$, regeneration of a short transverse segment, $c d e f$ in $A$, showing regulation of proportions as in $B^{\prime}$ and $C^{\prime} ; I$, heteromorphosis in an individual split lengthwise from posterior end. Eyes and pharynx are shown by outlines within the figures; scar tissue by stippled areas. ( $I$ after Morgan.) 
matter how the piece may be cut, the axes of the old body sumehow become those of the new. It is as though every part of the original were laid down on certain lines and these lines persisted in the piece removed. Heteromorphosis is, of course, an exception, though not impossible of explanation in terms of the normal polarity.

The power of regeneration is widely distributed among the lower organisms. Generally speaking, those animals and plants which exhibit in their normal life-cycles marked powers of vegetative reproduction (budding, fission, and the like) are found to possess the greatest capacity for regeneration. Specialized forms, which reproduce only by means of germ-cells, can do little more than heal wounds of limited extent or replace lost appendages, as does the crayfish. Studies upon regeneration have shown the nature and extent of regeneration in a wide variety of forms. With these facts known, it has been possible to consider the more subtle factors involved. The problems of regulation and polarity have been attacked in recent years with some degree of success. Study of the conditions under which a piece of an organism forms a complete individual has thrown light upon the nature of the organized system that we call an individual. ${ }^{12}$ Regeneration, regulation, and polarity are part of the larger phenomenon of growth and differentiation exhibited by all many-celled organisms. Results in these fields interlock with those obtained in the study of embryonic development. The piece of an organism which regenerates the whole is obviously possessed of the same kind of potentiality that exists in embryonic tissue. How adult tissues can thus exhibit embryonic capacities is an interesting problem, the investigation of which may eventually throw light not only upon embryonic development but also upon certain pathological conditions which exist at times in the human body and in the bodies of higher animals and plants.

Natural Death:- The early stages of development, which ${ }^{12}$ Child, C. M., "Individuality in Organisms, 1915." 
constitute the subject-matter of embryology, are not the only progressive modifications, occurring within the life of the many-celled animal. There remain the minor changes of adult life, and the degenerative changes immediately preceding the natural death of the individual. Here again, we find problems that must be attacked experimentally. Death occurs by accident in the vast majority of animals. In nature, only the merest fraction of any generation lives to grow up. The individuals, which live to grow old, are frequently killed by their enemies before natural death can intervene. When accidental death does not occur, natural death is, seemingly, the inevitable fate of the individual among the multicellular animals. ${ }^{13}$ But this natural death does not come to every cell encompassed by the body. Certain of the germ-cells continue to live, through their descendants which constitute the next generation. A majority of the germ-cells perish, while a small minority of them survives, if the race continues to exist. Hence, the germ-cells are potentially immortal, while the body-cells are destined to perish.

It is perhaps worth while to inquire why one type of cell is thus able under certain conditions, namely, union in fertilization with another germ-cell, to continue its existence to another generation, and so perhaps to all future generations. The neighboring cells of the body are destined for old age and death. Why this difference between germ and body-cell? Save for cases of normal parthenogenesis, the germ-cells die, if they do not unite in fertilization. Continuation of their life hinges upon this one small matter of union with another cell. The balance between death and life is so slight that, in some of the experiments in artificial partheno-

${ }^{13}$ In animals which reproduce by budding or fission, it may be that the individual can live on, as do the germ-cells. This has not yet been proved experimentally for any many-celled animal; but plants like the potato or the begonia may be reproduced indefinitely from cuttings, and, theoretically, an animal like a hydra or a planarian might continue budding or fission forever, and thus continue living without old age or sexual reproduction. 
genesis, stimulation with a particular compound in an extreme state of dilution keeps the egg alive, by causing it to develop. ${ }^{14}$ If so small a difference determines life or death for the germ-cell, it may be argued that the senile changes of body-cells are the result of conditions that may some day be comprehended. Is it only a dream to hope that biological science will eventually so analyze the conditions of bodily death and germinal immortality that death, as a natural process, may be postponed if not eliminated? ${ }^{15}$

Genetics and Cytology:- Twentieth century study of evolutionary problems has come to be known as the science of Genetics. Investigation of the origin of species has passed beyond the stage where it is wholly observational. Knowledge of heredity and variation, acquired during the past thirty years, has brought the problem well within the scope of experimentation. The experimental method has been established in this branch of zoölogical study, although its application has not yet produced results which have led to agreement regarding the causal factors in evolution. Our earlier contention that evolutionary problems are, in their

${ }^{14}$ The eggs of the marine worm, Thalassema melita, may be caused to develop by artificial parthenogenesis after an immersion for 5 minutes in a solution containing 17 cc. of $\frac{M}{10} \mathrm{HCl}+85$ cc. of sea-water. This is the equivalent of a solution of about $.0608 \%$ of actual hydrochloric acid. Lefevre, George, "Artificial Parthenogenesis in Thalassema Melita," Jour. Exp. Zoöl., Vol. IV, No. 1, 1907.

${ }^{15} \mathrm{E}$. Metchnikoff has discussed at length what science can do to alleviate such disharmonies of the human constitution as the evils of old age and the fear of death, in his book, "The Nature of Man." (Translation edited by P. C. Mitchell, 1903.) Metchnikoff's later theories, concerning the prolongation of human life, through the better adjustment of the physiology of nutrition ("The Prolongation of Life," 1908), seem hardly tenable at the present time. But his formulation of this very human problem illustrates the practical answers proposed by science to a group of questions, which, in the past, have been answered only by the metaphysics of religion and philosophy.

More concrete aspects of the problem of death are briefly summarized by: Jennings, H. S., "Age, Death, and Conjugation in the Light of Work on the Lower Organisms," Popular Science Monthly, June, 1912; and Loeb, Jacques, "Natural Death and the Duration of Life," Scientific Monthly, Dec., 1919. 
final analysis, cell problems is again illustrated by the present affiliation of genetics with cytology.

Cytology, or the science of the cell, concerns itself with structure and function in cells of every sort. But the cytologist has been so occupied with the germ-cells and with the early phases of development that cytological investigation to date is almost a synonym for germ-cell investigation. Germ-cells or gametes are the links between successive generations. Every many-celled animal is at one period of its life-cycle encompassed within the limits of the single cell formed by the united ovum and spermatozoön. The gametes have naturally assumed an overwhelming importance in cytology. They are no less important in genetics, because the latter science must know how adult characteristics are transmitted through the germ-cells to the next generation. Genetics and the cytology which deals with germ-cells are but different aspects of the same fundamental problem.

We have already described the probable mechanism of Mendelian heredity as it appears in the chromosomes. The interlocking of genetics and cytology was inevitable, once the facts regarding the gametes had been established and once Mendel's epoch-making discovery had become generally known. The chromosomes of the ripening germ-cells were found to behave in a peculiar manner. Mendelian unit-characters were found to be inherited in a fashion equally distinctive. Suddenly it was realized that the chromosomes offered an explanation of the segregation which is the essential feature of Mendelian inheritance (cf. Fig. 20). ${ }^{16}$ Thus the experimental results of genetics became of interest to cytology and the results of cytological study assumed importance for genetics. The latter science has arisen upon an experimental foundation in the breeding

${ }^{16}$ Wilson, E. B., "Mendel's Principles of Heredity and the Maturation of the Germ-Cells," Science, Dec. 19, 1902. This brief paper summarizes the evidence at a time when the cytological mechanism, which has since herome familiar, was just beginning to be understood. 
of animals and plants, first by the practical man and later by the investigator. Cytology has heretofore consisted almost wholly of observational studies. But under the stimulus of genetics a measure of experimental work is being undertaken. Genetics and the cytology of germ-cells are now advancing side by side. The present theory of sex-determination, which is an outcome of investigations in both cytology and genetics, illustrates the union of these two fields of study and also the progress toward experimentation.

The appearance of genetics as a full-fledged science is, therefore, a recent development. Mendel's original publication appeared more than a half century, ago (1866). But general knowledge of this great law of heredity dates from the closing decade of the nineteenth century, when it was independently rediscovered and when the original discovery became generally known. With Mendel's law as a clue, an amazing advance has been made. So much has been learned regarding heredity and variation that Genetics has come into being as a science. Already there are professorships and research endowments within this newly created field. Popular interest in heredity has stimulated the publication of many books and articles in recent years. Mendelism is a familiar topic, and the science of genetics is becoming almost as well known to the public as bacteriology or pathology.

Sex-Determination:- The factors which determine sex in man and the familiar animals have been the subject of innumerable theories from ancient times until the present day, all of which now appear to be groundless. Toward the close of the nineteenth century the hypothesis most widely accepted was that the sex of the individual was dependent upon the amount or kind of food received during the earlier period of development. This theory was believed to have experimental evidence in its favor and hence obtained recognition in biological circles. It was easily apprehended and so gained wide acceptance in the popular mind. By the terms of this theory, the sex was at first undetermined. As 
development proceeded, the individual became a male, if it happened to receive a scanty diet; a female, if it chanced to be well fed. Experiments in overfeeding and in underfeeding of the young of vertebrates like the frog and of invertebrates like the moth gave what many regarded as conclusive evidence.

But the experiments in feeding, which were supposed to have thus determined the sex, have been repeated in recent years, with results that do not confirm the earlier conclusions. ${ }^{17}$ Moreover, it has been found that the sex of many animals is seemingly determined as early as the stage when the individual originates by the union of egg and spermatozoön. The individual becomes a male or a female at the very beginning. Nothing that happens in the subsequent development changes the sex as thus early established.

The facts upon which the new theory rests may be illustrated by Fig. 27. As we have seen (Fig. 13), the nuclei of cells exhibit at the time of division certain bodies, the chromosomes, which occur in pairs (Fig. 16) and in numbers that are constant for a given species. In the present instance four pairs is the number chosen for the purposes of the diagram (Fig. 27). It has been observed, in numerous cases among insects and in a smaller list of other forms, that the number of chromosomes is not the same for the two sexes, since males lack one member of one of the pairs. ${ }^{18}$ The chromosomes of this particular pair are termed " $\mathrm{X}$ " chromosomes, or better sex chromosomès, because their distribution at the time of fertilization appears to determine the sex of the individual. Thus, the $\mathrm{P}_{1}$ adults of

${ }^{17}$ In the language of one investigator, these later experiments "seem to show that sex is not determined by the quantity or the quality of the food that the larvæ receive." This conclusion was based upon experiments with tadpoles of the toad. It agrees with that reached by other investigators who have reinvestigated the influence of food upon sex in frogs, moths, and other forms. King, H. D., "Food as a Factor in the Determination of Sex in Amphibians," Biol. Bulletin, Vol. XIII, No. 1, Junc, 1907.

${ }^{18}$ In a few cases the condition is reversed and it is the female that lacks one chromosome-several moths and butterflies and several birds. 


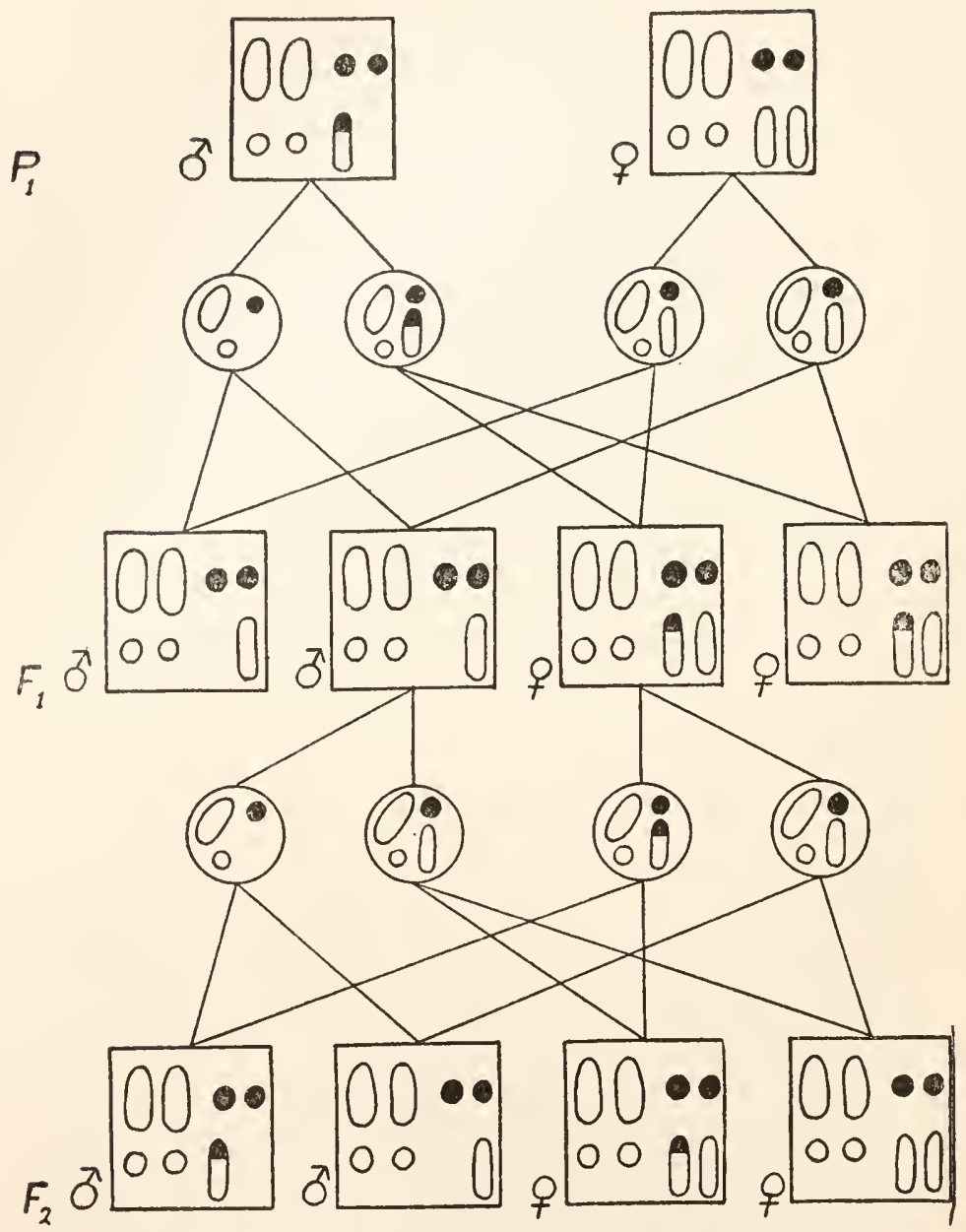

Fig. 27. Chromosome Theory of Sex Determination and Explanation of Sex Linked Heredity in Terms of Chromosomes. The number of chromosomes is taken as $6+1 x$ in the male and $6+2 x$ in the female or $3 n+1 x$ and $3 n+2 x$ when $n=$ the number of pairs of non-sex chromosomes. The chromosome, assumed to carry the determiner in a case of sex linked heredity like color blindness in man, is partially shaded. See discussion in text. Squares represent adult individuals, circles gametes (ova and spermatozoa). 
Fig. 27 give rise to germ-cells having one member of each pair of chromosomes. But in the male one-half of the spermatozoa will be without an " $\mathrm{X}$ " chromosome, because males possess only one member of this pair. In the female (Fig. 27, $\mathrm{P}_{1}$ ), each egg will, of course, have a single sex chromosome, since both members of this pair are present in the cells of females. There are, therefore, two kinds of spermatozoa, (1) those with, and (2) those without the " $\mathrm{X}$ " chromosome; but only one kind of ovum. When such sperms and ova meet, with equal chances of union, there will be, by the laws of chance, equal numbers of males and females produced, as shown by the chromosome combination in the $F_{1}$ generation of Fig. 27. This agrees with the observed fact that in many animals the numbers are equal in the two sexes and explains how the formula for the cells of a female comes to be $2 n+2 x$ and for the male $2 n+1 x$. There has, therefore, been established for a considerable number of animals, a theory of sex-determination, which recognizes not only the germ-cells as the important item but a specific chromosome within the germ-cells. This theory is, therefore, a part of the general theory of chromosomes in relation to heredity.

Through the work of the geneticist, this recent cytological theory of the determination of sex is correlated with facts known for the inheritance of what are termed sex linked characters. The peculiar inheritance of color blindness in man, which has long been known to be related to the sex of the individual, may thus be explained. Referring again to Fig. 27, let us assume the existence of sex chromosomes in the human body and its germ-cells, and assume further that one of these chromosomes carries the factor for color blindness. ${ }^{19}$ The presence of such a factor may be indicated by

${ }^{19}$ The difficulty in obtaining satisfactory material makes the number of chromosomes in man still a matter of doubt. Winiwater, H. v. (Arch. de Biol., Vol. 27, 1912) has reported 48 in the female and 47 in the male, but these results have been disputed. 
shading a portion of one of the " $\mathrm{X}$ " chromosomes (Fig. 27). Color blind men are known to be much more numerous than color blind women. But color blindness is transmitted by a human male through his daughters to approximately one-half of his grandsons.

Explanation of this very peculiar inheritance is as follows: A color blind man is mated with a normal woman $\left(\mathrm{P}_{1}\right.$, Fig. 27). The single sex chromosome of the man carries the factor for color blindness, as shown by the shading. Onehalf of the $\mathrm{P}_{1}$ germ-cells of the male will be free of the defect, since they possess no " $\mathrm{X}$ " chromosome. In the $\mathrm{F}_{1}$ generation, the males are all normal and free from the defect. But all the females have an " $X$ " chromosome (partly shaded) which carries the defect. For some reason such a "single dose" will not produce color blindness in a woman although it does so in a man. These $F_{1}$ females transmit the chromosome bearing the defect in the manner shown $\left(\mathrm{F}_{2}\right)$, so that, where numbers are sufficient to indicate the ratio, one-half the grandsons of such matings are color blind and the other half normal; while the granddaughters, although all seem normal, are one-half free of the defect and one-half transmitters of color blindness as the figure shows. Color blind women result from matings in which two " $\mathrm{X}$ " chromosomes, each with the color blind factor, are brought together. Such a combination would be possible in one-half the daughters arising from color blind men mated with women who were transmitters, i. e., possessed a single dose of the defect. ${ }^{20}$

These results which have been obtained from the study of sex linked characters, find their explanation in the work of cytology. The latter science has been mainly observational. The cytologist is now stimulated to extend his analysis by means of experimentation. Hybridization offers an opportunity to produce new chromosomal combinations by experimental crossing. The observational foundation is sufficient for the beginning of such experimentation.

${ }^{20}$ Morgan, T. H., "Heredity and Sex." Cf. for extended discussion. 
If sex is determined by the kind of spermatozoön which happens to fertilize a particular egg (Fig. 27), the difficulties in the way of sex control seem insurmountable. There appears no immediate prospect of controlling sex production in man and the domesticated animals. But something has been gained if it becomes clear that we cannot alter the maleness or femaleness, which is established at the time of fertilization, by changing the food or environment of subsequent stages. The point of attack is known, even though control seems well-nigh impossible in the event that sex is irrevocably determined at the time of fertilization. Investigation is pressing so closely upon the solution of the whole question that the factors controlling the union of the germ-cells in fertilization, and hence the sex of the individual, may be discovered sooner than one expects. Control of sex in man and the domesticated animals is, therefore, a remote, though not an unthinkable possibility. ${ }^{21}$

The changes from the origin of an individual at the time of fertilization to its disintegration in death are a neverending wonder to the advanced investigator as well as to the novice. So manifold has been the work of determining the structural changes, by which the egg becomes the adult, that embryology has but recently begun the experimental analysis of causation in development which is illustrated by the work above described. In this more intensive study, experiment and observation must, of course, be inextricably interwoven. Never the less the major problem henceforth must be discovery of underlying causation, rather than description of structural sequence.

${ }^{21}$ Although sex-determination by means of the sex-ehromosome appears to be well established in certain animal types, there may be exceptions to the established scheme. Also, there may be other faetors which have a determinative aetion. The studies of Riddle upon the pigeon and those of Whitney and of A. F. Shull upon rotifers, together with the work of F. R. Lillie upon sex-hormones in eattle, illustrate the complexity of the problem and should make us hesitate to aeeept the ehromosome-theory as a universal explanation of the determination of sex. 


\section{PROBLEMS OF ANIMAL BEHAVIOR}

The behavior of animals has been recognized as a subject for scientific investigation only within recent times. So long as the idea of souls or similar activating agents persisted, there was scant opportunity for an analysis of behavior in terms of science. The earliest scientific attack dates from the work of Descartes in the seventeenth century, who seems to have originated the doctrine "that the bodies of animals and men act wholly like machines and move in accordance with mechanical laws." The scientific study of behavior was thus begun under the stimulus of the hypothesis that animals are automata, a theory which is a phase of the more general hypothesis known as the mechanistic conception of life. ${ }^{22}$

Those who originally maintained the Cartesian doctrine soon outstripped themselves and their teaching fell into disrepute. No real progress was made during the eighteenth century, but in the early part of the nineteenth century we find a tendency to interpret the behavior of animals as like that of humans. Interest centered about exaggerated and uncritical accounts of the intelligence of the higher animals. The study of animal behavior consisted largely in the collection of anecdotes, the scientific value of which was passed unchallenged, outside of scientific circles, until a very recent date. ${ }^{23}$ Such work had its value because it fostered interest in animals and in their humane treatment by man. It was possibly a reflection of the romantic period in literature and catered to imagination rather than to reason.

With the establishment of the evolutionary doctrine soon

${ }^{22}$ Huxley, T. H., "On the Hypothesis that Animals are Automata," Collected Essays Vol. entitled: "Method and Results."

${ }^{23}$ The collection of stories, entitled "The Animal Story Book," and edited by Andrew Lang, although published at a much later date (1896), is representative of the period in question. Its literary quality is pleasing and its influence in arousing sympathetic interest is of the best, but as scientific natural history it is, of course, unreliable. 
after the middle of the century, the genetic relationship between animal and human behavior became an absorbing problem. Darwin's book upon "The Expression of the Emotions in Man and Animals" (1872) is representative of the underlying assumption that human behavior is an outcome of evolution from the behavior of higher vertebrates. The results of the best of this investigation, by such men as Lubbock, Romanes, Preyer, and others, have been largely confirmed. It is important to note that their work was experimental as well as observational and that it must be highly regarded when we consider that "these investigators were interested in the origin and evolution of responses and of psychic phenomena, and not in the mechanics of reactions." 24

Toward the end of the nineteenth century interest again swung in the direction of the reduction of animal behavior to mechanical principles. This interpretation of behavior has been widely advertised in recent decades and experimental methods have been much in evidence. But observation is still of great importance. However much we may desire to reduce a problem to one critical experiment, observation is frequently a necessary preliminary to the experimental attack. At the present day, the sane verdict on the question whether the animal body is a machine, whose behavior is predictable in terms of a mechanical system, is that the case is not yet proven, although many simple responses appear to be mechanistic in their nature. ${ }^{25}$

${ }^{24}$ The paper by S. O. Mast on the "Problems, Methods and Results in Behavior," Science, Dec. 13, 1918, from which the above quotation has been drawn, contains an authoritative résumé of the history and present standing of the study of behavior.

${ }^{25}$ The volumes by J. Loeb, "The Mechanistic Conception of Life" (1912) and J. S. Haldane, the "Organism and Environment" (1917) represent, on the one hand, the point of view of an extreme mechanist, and on the other, that of an investigator who is an anti-mechanist rather than a vitalist. Hans Driesch, in "The Science and the Philosophy of the Organism" (1908), has pushed the vitalistic theories to a greater extreme than any biologist of the present generation, using the facts observed in development as the principal 
Opposed to the doctrine that the animal body is a machine, whose responses are predictable in terms of a mechanism, is the doctrine of vitalism, by which it is maintained that the actions of the living body involve something which is not present in any non-living machine. Of course, the mechanist does not maintain that all vital processes have been reduced to mechanical principles. He only maintains, as his working hypothesis, that they will be so reduced when we know more about them. The vitalist maintains, as his hypothesis, that mechanistic explanations are insufficient. The whole question of mechanism versus vitalism has probably attracted much more attention than it deserves. The agnostic position would seem the only tenable one for a long time to come. The vitalist should remember that biological progress seems to be made in the direction of mechanistic explanations. The mechanist should remember the complexity of the phenomena and the scant progress that has been made toward their comprehensive solution. Moreover, undue emphasis of the mechanistic conception has certain important human implications, which the mechanist tends to overlook. ${ }^{26}$ As a practical question, the adoption of a mechanistic conception of human behavior basis for his theories. The ideas of H. S. Jennings, expressed in his "Behavior of the Lower Organisms" and numerous special papers, have always seemed to the writer to represent a discriminating outlook upon the behavior problem as a whole.

${ }^{26}$ These implications are well stated by S. O. Mast, loc. cit., who writes as follows: "Mechanism implies, as previously pointed out, that every phenomenon is specifically associated with changes in the special interrelationship of material particles, masses or systems, changes in or states in material configurations, which are absolutely determined by preceding changes or states in material configuration. Consequently, if mechanism holds, every phenomenon, every act of every organism that ever existed, exists now, or ever will exist, is absolutely determined with reference to character, time and place and has been thus absolutely determined from the very beginning. If you can in reality, at any given instant, move your hand either to the right or to the left, mechanism breaks down, for according to the laws of mechanics, if you move your hand to the right, that movement is by the material configuration within and about you absolutely determined with reference to place, extent, duration and time and you could not possibly have moved it to the left at that time." 
seems inadvisable in the absence of overwhelming evidence. And such evidence does not exist. Mechanism is a fatalistic doctrine, and fatalism whether promulgated under the garb of science or theology exercises a pernicious effect upon human conduct.

The question of mechanism in behavior is only one phase of the investigation of animal reactions at the present day. The nature of pleasure and pain and their distribution in the animal series is another problem which is theoretically interesting and one which has practical bearings. Knowledge and not emotion should be the basis for our consideration of the feelings of animals. As yet we have no thoroughgoing knowledge for the pleasure-pain problem, considering the animal kingdom as a whole.

Another problem which many be investigated independently of the problem of mechanism versus vitalism is the origin and evolution of consciousness. By this is meant the awareness or subjective experience which is the basic feature of each human personality and which we infer as existing in other human beings and in the mentality of the animals most like ourselves. Two methods of investigating the problem of consciousness present themselves. The older introspective method, which has not yet become obsolete, and the newer method of comparative behavior. By the former method we obtain the clue which leads to the formulation of the kind of consciousness that presumably exists in our fellow men and in the minds of animals. The comparative study of animal behavior can yield a clue to what goes on inside the animal mind, only when we interpret behavior in terms of the results obtained by our own introspection. Some modern investigators are content merely to describe how the animal behaves in response to stimulation and to put aside all consideration of the subjective states which may be involved. To most of us the question of how the awareness of the animal resembles our own consciousness is too interesting a problem to be thus thrust aside. 
Experimentation is the conspicuous method, throughout this modern study of behavior. Observation is still fundamental and is often the only feasible means of attacking the problems. But here, as in other scientific lines, the experiment under controlled conditions is the goal of investigation. In recent years the study of behavior has been extended to the lower organisms, in the hope that simpler forms of life would be more understandable in this particular and that simpler types of behavior would be discovered and synthesized to explain the reactions of higher animals. Much has been accomplished. The behavior of forms like the infusoria is now believed to be vastly simpler than when likes and dislikes, comparable to those of men, were ascribed to these lowly beings. Yet the reactions of the animal cell are much the same, whether the cell is that of an amoba or one within the human body. The responses, which the living protoplasm makes to changes in its environment, are more complex in the many-celled body, in so far as this body contains many different kinds of cells. But it is not clear that the responses of individual cells of the many-celled body are more complex than the responses of the individual cells of the protozoa. The principal advance that has been made, toward analysis and subsequent synthesis of the elements of behavior, is the showing that behavior is, in its last analysis, a problem of cellular functions.

\section{PROBLEMS OF NATURAL HISTORY}

We have seen that during the Scientific Renaissance studies in natural history constituted one of the two great lines of biological advance. Until the middle of the nineteenth century, perhaps the major part of zoölogical effort was devoted to studies upon animals and plants in the open country. The work to which the naturalist gave himself within doors was carried on primarily with a view to the classification of material collected in the field. ${ }^{27}$ The an-

${ }^{27}$ Such work as that recorded in Darwin's "Naturalist's Voyage round 
atomical, microscopical, and physiological aspects of zoölogy developed mainly in relation to medicine. The laboratory of the present day has come into existence in response to the demands of this phase of zoölogical inquiry. The great museum, with its staff of collestors and investigators and its expeditions for the collection of material for research or for public exhibition, is the modern representative of old-time natural history.

Studies in natural history were important during the centuries of their inception, because they enabled men to appreciate the wealth and diversity of organic nature. They were also a prelude to the doctrine of evolution. At the present time their continuation by our museums is particularly important as a means of preserving a record of the larger forms of life, which have inhabited the earth during the Age of Man but which are fast approaching extinction, ${ }^{28}$ and as a means of cultivating the esthetic and recreational values of biological science. The sum total of scientific work now being conducted in natural history is probably greater than ever before. The advent of intensive study within the laboratory and the spectacular control, which laboratory workers have now attained over certain biological phenomena, have caused the work of the naturalist to be regarded as one among many lines of study, and sometimes a dilettanti line at that. The latter point of view is unfortunate in the mind of the the World," published in 1845, and Bates' "Naturalist on the Amazons" (1863) are representative of the best in the older period.

${ }^{28}$ The progressive destruction of wild life, in all parts of the world that have been gripped by western civilization is appalling from the standpoint of the naturalist. Even game preserves like the national parks of the United States are not safe from the cupidity of business enterprise. Unless there is a radical change in popular feeling at an early date, the extermination of all the larger mammals not capable of domestication and of many of our song birds is a matter of decades rather than centuries. Perhaps when it is too late, the world of living things will be far less interesting because the birds are mostly English sparrows and the mammals rats and mice. But it is still believed that what we of the West call progress must continue. The volume by W. T. Hornaday, entitled: "Our Vanishing Wild Life," contains a statement of the present situation and an appeal for its amelioration. 
public and reprehensible on the part of the laboratory biologist. Popular appreciation of this biology of the field and shore is attested by the enormous sales of books upon birds, insects, shells, and the like. Interest in natural history is quite spontaneous among children and would, no doubt, find more expression in the recreation and outdoor esthetic enjoyment of adult populations, if Nature Study were effectively taught by the schools.

The scientific attitude toward this modern natural history or field biology assumed a degree of hopelessness during the closing years of the nineteenth century. The complexity of inter-relationship between living things, as observed in the field, was appalling. Studies on evolutionary problems had been largely field studies. The evolutionary theory seemed, of necessity, to be lacking in precise evidence for evolution in the present. Fruitless discussion had characterized the later years of the so-called Post-Darwinian Period. Insurmountable obstacles appeared to stand in the way of progress beyond the analyses made by Wallace and Darwin. Although the zoölogist is still appalled by the magnitude of the task, the problems of natural history have been attacked anew by the modern science of Ecology. If they are still far from being solved, progress has been made. The ecologist needs all the powers of observation possessed by the older naturalists, together with the mental equipment of the experimentalist. What he does is to take the older observations for what they are worth, and, by carrying the intensive methods of the laboratory to the field and bringing the field into the laboratory, attempt an analysis of the complex inter-relationships which exist in nature. He is not unduly optimistic; nor does he believe he will shortly ascertain the many factors involved. But step by step progress is being effected. It may be hoped that some of the larger problems will be solved, if industrial development does not obliterate too rapidly the less resistant forms of life.

The science of ecology, which has thus supplemented 
modern natural history, further illustrates the cliange from observation to experimentation. The earlier studies were, almost without exception, observational in their nature, but a point was reached where progress became impossible by the continuance of observation alone. No one recognizes more clearly than does the ecologist the difficulties which attend the introduction of experimentation in field zoölogy. Observation still constitutes the major method. In the plant, which is rooted to its environment, experimental investigation is less difficult, and hence the ecology of plants has advanced beyond that of animals. Yet in spite of the difficulties, no one doubts that here, as elsewhere, observation will be increasingly supplemented by experimentation.

\section{RELATION OF ZOÖLOGY TO OTHER SCIENCES}

The adoption of this growing measure of experimentation has had an important bearing upon zoölogy in its relation to allied sciences. For one thing, many biological interests that were becoming divergent have become unified. Toward the close of the nineteenth century it seemed that such biological studies as those found in the works of Darwin were becoming impossible, because of the appalling amount of special knowledge in the fields of zoölogy and botany. No man could longer presume to become a master of both sciences. While this is increasingly true, we find to-day that the investigation of general biological phenomena, such as growth, regeneration, heredity, and the like, leads to the study of animals and plants by the same investigator. The botanist and the zoölogist find themselves on common ground when engaged in such investigations. A separation which had seemed an inevitable but regrettable incident in the advance of science has been at least postponed.

Again, a closer union has been effected between the biological and the physico-chemical sciences, through study of the physico-chemical processes that occur in the bodies 
of lower animals and in plants. These have long engaged the attention of physiologists, but until recently interest has been centered upon the higher vertebrates. At the present time, zoölogists and general physiologists are so engaged with the bio-chemistry and the bio-physics of both the simpler and the more complex organisms that the intelligent reading of many zoölogical papers demands as much or more knowledge of physics and chemistry as of natural history. It may be noted, as a sign of the times, that candidates for advanced degrees in zoölogy are now expected to be wellgrounded in chemistry and physics, as well as in general zoölogy. These physical sciences are important for the zoölogist, not only because they afford a knowledge of the facts but also because they foster an appreciation of experimental methods.

The ancient affiliation between the biological sciences and medical science continues. The rôle of insects in disease, the new sciences of Protozoölogy and Parasitology, the interest of the medical profession in heredity, the interest of the zoölogist in the physiological facts brought out by serumtherapeutics, by the study of endocrine secretions, and the like, are examples that illustrate the many points of contact. Zoölogy arose in close association with medical science. The more scientific medicine becomes the greater will be its demands upon zoölogical science. Extended medical experimentation upon human beings is impossible, though it often happens that the physician sees the end results of such experiments, as when a community begins the use of water from a filtration plant after long experience with water from a contaminated source. The experimental work of medicine must be accomplished mainly by use of animals. Since this experimentation is necessary for the advancement of medical knowledge, medical investigation must deal with zoölogical material. In the past it has utilized the higher vertebrates, such as the cat, dog, rat, and guinea-pig. As the human mechanism becomes subjected to a more searching examina- 
tion, more fundamental knowledge will be demanded and medical science must draw upon every part of the animal kingdom. The lower invertebrates and the protozoa are already familiar objects in medical laboratories.

As zoölogy becomes more exact in its conclusions, it will have greater value in the social sciences. At present the influence of biological science within these fields consists largely in the point of view which it imparts. But the significance of zoölogical and particularly medical knowledge is becoming evident to the social worker. He is eager for the latest facts on heredity, hygiene, and sanitation; and this eagerness will be lasting. The fact that the human species is a product of evolution is acknowledged by students of society. But we need a wider understanding of the zoölogical basis of human behavior than now exists. Once established, such an understanding must exercise a profound effect upon the social activities of the human race. Now that zoölogy is progressing toward the experimental analysis, and hence the control, of vital phenomena, its conclusions will be held in more esteem, because they will rest increasingly upon experimentation. In the future, the zoölogist will be heard upon a subject like heredity, not for his much speaking, but because he presents facts that cannot be denied and that are obviously important for the welfare of mankind. 



\section{PART III}

THE PRESENT IMPORTANCE OF SCIENCE 



\section{CHAPTER IX}

\section{PHILOSOPHICAL AND PSYCHOLOGICAL ASPECTS OF SCIENCE}

Science and philosophy must go hand in hand since the problems of organized thought have scientific bearings. Human thinking may be regarded as an outcome of organic evolution and one of the ultimate problems of science is the relation of mind and matter. How a thinking race arose in the course of thousands of years, how thinking men come out of germs during the brief span of individual development, and how the nerve cells of the brain are related to consciousness are problems which the scientist should investigate, even though their investigation leads him within the domain of philosophy. Moreover, the natural sciences rest upon certain fundamental philosophical assumptions such as the theory that all facts of experience may be systematically related, through the principle of adequate causation. The man of science is a philosopher in spite of himself whenever he attempts to determine the ultimate realities of science. Unless he accepts the naïve conception of nature and assumes that the external world is exactly what it seems to the unthinking mind, he finds himself in the grip of philosophy and must acknowledge his affiliation.

\section{THE FACTS AND KNOWLEDGE OF SCIENCE}

An examination of the facts of natural science, which are commonly assumed to be realities external to ourselves, will illustrate the assumption by science of philosophical hypotheses. Before proceeding to this examination, let us have in mind the familiar distinction between the subjective 
and the objective, taking it in the sense of what is within and what is outside ourselves, the $I$ as distinct from that which is not myself. We know the subjective element, because we are conscious of our own existence and of our mental processes. Hence there is one class of facts which is subjective in origin and another which originates in sense-impressions which are assumed to be induced by an objective or external reality. We know the objective element solely through these impressions of our sense-organs. The ego is like a telephone operator shut in a central office and knowing nothing of the outside world save by what comes in through the receivers. To the objective or natural sciences, sense-impressions are the ultimate reality upon which must be based any theory of an external universe of matter.

We may pursue the case as follows: A man has reason for believing, because of what he sees in bodies like his own, that his particular human body presents anatomical and physiological phenomena of the kind demonstrable in other human beings and in the higher vertebrates. The individual knows his own conscious existence first hand, and infers the existence of everything else. Granting that $I$ know I exist, and you know you exist, and that we can each infer. that the other exists, how do we draw such an inference and what do we mean when we say that this or any other inference has scientific validity?

We know the outer world only through the medium of our sense-organs. You see a book before you, with its red cover, gilt letters, and white leaves; it feels hard; it creates a noise when dropped; it smells like a book fresh from the bindery. If you desire yet another form of sense-impression, you may taste the cover or the leaves, as you perhaps remember doing when a boy at school, and so experience the last type of first-hand knowledge which is presented by the more familiar senses. You know that such an object as the book exists only by these evidences derived from your senseorgans and termed sense-impressions. You have learned 
to say that light reflected from the book affects the retina of your eye, which in turn stimulates your optic nerve, which, in its turn, stimulates the centers of your brain. You know only the sensations which are thus received; of the nature of books you know nothing; for you perceive nothing beyond the group of sense-impressions which you call a book. If the book is a thing in itself other than these impressions, you do not know it; for your ultimate objective reality consists solely of sense-impressions. ${ }^{1}$

The case is not otherwise with your knowledge of your fellow men, and even of your own body-sense-organs included. A friend before you is a group of sense-impressions,- like the book, save that among the many senseimpressions which constitute your friend there are those leading you to infer the existence of another personality like your own. These three cases, the book, your friend, and your body, are typical of the whole external world of persons and things; and sense-impressions are thus the ultimate external reality that is perceived by the human mind. Upon these impressions we build, within our minds, a so-called external world. The problem of what lies behind the senseimpression, what is the nature of the thing in itself, science leaves to philosophy, believing that the nature of this ultimate philosophical reality is not open to investigation by any of the scientific methods now available.

But one's knowledge of a book could never be so simple a matter as above described, unless indeed he were a savage who had never before seen a book. No sooner do the senseimpressions reach his consciousness than he remembers other books. The title attracts his attention; he remembers books with similar subject-matter; and as he reads the pages his mind may call up a multitude of earlier sense-impressions. He may remember how he previously correlated impressions derived from books, and conceived of books in general, or

${ }^{1}$ An exposition of the facts of science, which is similar to the one here given, appears in Part I, Chapter II of the "Grammar of Science," by Karl Pearson. 
paper in general, or lettering in general. The sense-impressions received from the printed pages are signs which enable him to conceive of possible sense-impressions and to recall so wide a range of previous impressions and the conceptions derived therefrom, that the reading may effect a profound reorganization of his intellectual life. Starting with senseimpressions past or present, which seemingly constitute our only means of knowing what goes on outside our minds, which are for us the real outside world, our complex mental states are in some way built up, until it is impossible to say whether anything like what we term consciousness could exist in a being conscious of its own existence but devoid of sense-impressions.

It appears, therefore, that what we call external reality is, for the most part, created within our minds. Natural science is the discovery and systematization of facts whose basis is sense-impressions. Generalization consists in the interpretations we put upon our past and present experience with sense-impressions. A science that consisted of disjointed sense-impressions would be one of unrelated facts, whereas true science consists in the putting of simple facts together and obtaining facts of a more complex nature or generalizations. This point of view does not imply that science is merely a static organization of knowledge, although the accumulated facts of science may be so regarded. Like an organism, science is something happening. It is a process of finding out the relationship and the order of phenomena in nature. Predictability, based upon this ascertainment of order and relationship, is its most important function.

While the facts of natural science are in the first instance sense-impressions, its field is the content of the human mind. For out of sense-impressions, at first isolated and disjointed, we build up within our minds a theory of the whole which constitutes organized science. When this view is appreciated, one understands why scientists maintain that the facts 
compounded within our minds upon the basis of senseimpressions are the only trustworthy facts, aside from the subjective facts of the individual's existence and his knowledge of the modes by which the mind operates. One comes, therefore, to the belief that there is only one kind of knowledge concerning external realities, and only one way by which it is acquired.

Scientific reality, accordingly, consists in the fact, first, that we get the expected result in consciousness when we again experience a given group of sense-impressions; and second, that the mental states of other individuals appear to follow a similar course. One check upon the reality of any sense-impression and upon the validity of our conclusions therefrom is the commonness existing in our minds over a period of time and the commonness which appears to exist between the impressions in our minds and those within the minds of other individuals. A check may also be obtained by using other senses than the one temporarily in operation, as when we verify sight by touch. Herein lies the difference between reality, on the one hand, and delusion, illusion, and hallucination on the other. The vividness of those latter experiences, which are peculiar to the individual is not denied, what is insisted upon is the difference between that which is the product of a single mind and cannot be produced by other minds in a normal state, and that product which can be shared by many minds on the basis of a common understanding of sense-impressions.

In this connection the question arises whether the human mind has methods of obtaining knowledge regarding external realities other than the one above described, whether what is vaguely termed intuition, insight, revelation, or the like gives anything that can be dignified by the term knowledge. According to the scientific point of view, these mystical short-cuts to knowledge are valueless, because they are so dissimilar in different individuals that they fail to give sufficient commonness when comparisons are instituted. 
It is sometimes insisted that scientific knowledge is only second-hand knowledge, that conclusions, even more valid may be reached by what is popularly known as the method of intuition. The word intuition has a variety of meanings. But in the case under consideration, it is applied to a faculty for acquiring reliable information quickly and without due process of reasoning, to a kind of royal road leading straight to the solution of any problem. Where intuition is used to designate knowledge which is axiomatic, the scientist can have no objection either to the term or the fact. Thus, if one says he knows intuitively that $1=1$ or that $2+2=4$, it would seem that such knowledge is very near to that which defies further analysis and which must be taken intuitively at its face value, because our minds are so constructed that we cannot think otherwise.

We shall not venture to discuss the concept of intuition in its philosophical aspects. The kind of intuitions which are obstacles to the advancement of science are those of everyday life. When these are examined the following propositions are evident: Intuitions are effective only within the field of complex phenomena; they are most emphasized by persons not accustomed to careful analysis; they were formerly applied to many phenomena since brought within the grasp of science. All of which leads one to suspect that the matter is reducible to this: What is simple we reason out; what is complex and, therefore, not susceptible of exact analysis, we settle by a mental process of the same order as the hunch of the plain citizen.

The truth of these propositions is well illustrated by the history of knowledge concerning disease. A century ago, even a generation ago, an appalling amount of medical diagnosis rested upon an intuitive foundation. To-day, an increasing amount of such diagnosis rests upon a scientific knowledge of organisms and of specific substances within the body. The history of science is filled with similar examples of the unknown, and supposedly unknowable, of 
one age becoming the known and the predictable of the next. This being so, it is a fair presumption that what we decide to-day by intuition may, at a later day, be brought within the ken of science. Thus the realm of the intuitive becomes a lessening one. Its name is synonymous with the unknown or incompletely known, not with the unknowable. We have intuitions regarding what we do not as yet understand, and intuitions fade wherever scientific analysis establishes a foothold.

The weakness of intuition is its individual bias. It is the product of a single mind, not the collective agreement of individuals who have examined the same data. As such, it is always open to the suspicion of being influenced by delusion or prejudice. Intuition works differently with different persons, reflects to a large degree the personal equation, and has the marks of a process which is not and never can become reliable in the analysis of phenomena. The scientist, therefore, believes the method of intuition unsatisfactory as a source of knowledge. When he says he knows subjectively, he means only that he is conscious of his mental states and of their manner of operation; when he says he knows objectively, he means that any normal individual, who puts himself under similar conditions, will experience sense-impressions from which he may draw similar conclusions. The scientist does not claim to know everything. He does claim that such sources of knowledge as the intuitions of daily life, which are so frequently paraded as a superior means of knowing, are not knowledge in any sense, because they seem to represent either vagaries of the individual mind or thought-processes too unorganized to be of value in the determination of either external or internal realities. 


\section{THE METHOD OF SCIENCE}

If the field of the natural sciences is the content of the human mind as determined by the incoming sense-impressions, the method of these sciences is that by which the mind deals with the facts of sense-experience. What is called the external world is a creation of the mind, which, it is assumed, parallels an objective reality. ${ }^{2}$ The science of logic attempts to determine the methods by which the mind acts in dealing with the facts of experience. Science, therefore, depends upon logic to check its conclusions, but in the history of thought it is significant that the logic of scientific practice has preceded and not followed the development of logic as a science. Thus the deductive logic of Aristotle was founded upon the examples of mental procedure then in practice, while the inductive logic advocated by Francis Bacon, and elaborated by John S. Mill (1806-1873) and others in the nineteenth century, was a formulation of mental processes which had long been practiced and had already created modern science.

Science was described by Huxley as "trained and organized common sense," and the methods of scientific analysis as but extensions of those common in everyday life. ${ }^{3}$ Hence anyone who puts two and two together and draws conclu-

${ }^{2}$ Sellars, R. W., "Critical Realism," Chaps. I and II, presents a statement concerning this assumption of parallelism which is clear to the scientist at least.

${ }^{3}$ Huxley, T. H., "On the Educational Value of the Natural History Sciences." Collected Essays, Volume entitled: "Science and Education." This much-cited paragraph runs as follows: "Science is, I believe, nothing but trained and organised common sense, differing from the latter only as a veteran may differ from a raw recruit: and its methods differ from those of common sense only so far as the guardsman's cut and thrust differ from the manner in which a savage wields his club. The primary power is the same in each case, and perhaps the untutored savage has the more brawny arm of the two. The real advantage lies in the point and polish of the swordsman's weapon; in the trained eye quick to spy out the weakness of the adversary; in the ready hand prompt to follow it on the instant. But, after all, the sword exercise is only the hewing and poking of the clubman developed and perfected." 
sions that are justified by the facts of objective experience is performing a scientific act. The man of the street and the man of the farm have much in common with the scientist, though the latter may seem to them to be both fool and dreamer.

As there may be some question regarding the meaning of the term "common sense," we may agree at the outset that a man has common sense when he deals rationally with the facts of his experience. The man of common sense sees the whole situation or, as the scientist would put it, he considers all the data and draws his conclusions therefrom. We think a man's judgment sound, if he does what a well-balanced individual would be expected to do when confronted with all the details of a particular situation. The theorist fails if he does not consider the workaday elements of the case. The practical man fails if he judges solely by rule-ofthumb and without the light of theoretical considerations. Now science has gone forward in the past, not by wizardry, but by the application of this all-sided sense in the solution of its problems. The methods of thought which advance science do not differ in kind from those of the most hardheaded man of affairs who creates a business of international proportions.

The owner of a quarry uncovers a layer of rock different in appearance from any before offered for sale in his locality. Lacking expert advice, he begins to experiment and to make observations, with a view to determining the utility of the new material. After subjecting it to a variety of tests, he concludes that the stone can be put to certain uses. It is good for crushing and for rough masonry, but not for sills and lintels; good for road foundations, but not for surfacing. In reaching these conclusions, he first establishes certain facts; then compares these with facts previously known; then classifies the stone as good or bad for a given purpose; and thus arrives at the conclusion that a stone of this nature may be put to certain uses. He is now in a position 
to convince would-be-purchasers of the excellence of his material. An Indian, selecting the proper flint for his arrowpoints in the same locality centuries before, might have gone through similar mental processes.

If we compare the sense of science with the foregoing, the case is as follows: A geologist examines the same rock layer, because of peculiarities which have attracted his attention. He first makes a survey of the entire bed, collecting the fossils and observing structural features, comparing as he does so the present bed with others he has seen. Ripple marks and mud cracks may tell of shallow water, fossils may indicate a marine origin, distorted bedding planes may give evidence of lateral pressure. At last, he classifies the stone, as part of a well known geological horizon, and therefore belonging to a certain period of the earth's history. In such a case, the geologist believes he has reached conclusions obvious to others, and is prepared to take his colleagues over the ground, exhibiting facts and setting forth his inferences.

The quarryman, did he but know it, goes through similar mental processes; though he is likely to be led astray because his knowledge of rocks is after all limited, and because hope of gain is his main incentive. The advantage possessed by the geologist lies in his broader knowledge and in his desire to establish the facts rather than to make money. The point for us is the parallelism between the mental processes of the two men, which are in essence the inductive method of science.

Thus the scientific method, like the scientific fact, may be characterized by the adjective common. The facts and methods of science are those which may be shared in common by members of the human species. They are not the whim of one individual, but conclusions reached by individuals, who may be regarded as competent judges in the particular case, and who place similar interpretations upon groupings of sense-impressions past and present. This last does not mean that the mere holding of a belief by a large number of 
persons is evidence of its validity. We no longer suppose what is "believed always, everywhere, and by all" to be true merely because of its wide acceptance, as was once the case; for all may labor under similar delusions and thus hold the same false belief. It means that facts, which have been established by individuals competent in particular instances, remain constant, that is to say common, for other trained minds that examine the phenomena. The difference between this species of commonness and that supposed to be obtained by the esoteric insight of mysticism is that it rests upon sense-impressions, and not upon states which are purely subjective, and therefore individualistic. When these sense-impressions are sufficiently checked, common conclusions follow. But this does not mean that later senseimpressions of another sort may not alter these conclusions in the future.

The question as to who are the normal individuals also arises. To this one can only reply that the normal man is, like the average man a creation of the mind. Every individual has his abnormalities and his incompetencies, the subjective feature termed the personal equation must be acknowledged. But as a practical matter, those who are not too divergent get on well together. Obviously no two individuals can have identical sense-impressions of any socalled external object, but this does not prevent a measure of agreement. The more extensive is this agrcement, in both time and place, the more certainty may be attached to an interpretation.

Again, it may be asked, in view of the frequent differences of opinion among scientific men, whether any common interpretation of phenomena does actually exist. To which it may be answered that there are common interpretations with respect to certain phenomena, and such interpretations are increasing in number and importance with the advancs of science. To illustrate specifically: It is a familiar fact that all living bodies are composed of units known as cells. 
The exceptions to this cellular organization of protoplasm, such as multinucleated cells, plasmodia, syncytia, and so forth, can all be brought into alignment with the general theory of nucleoplasmic and cytoplasmic materials. There was a time in the history of biology when nothing of the sort was known, and later a time when an hypothesis of the universal cellular organization of living matter was proposed on a basis of limited observation. This working hypothesis was at first debatable. But the increasing number of cases in which cells were observed, soon led to the acceptance of the cell-theory as an established generalization, which may to-day be designated as a fact, since it is hypothetical only when we assume, as is done in the erection of the cell-theory, that all living things are constructed after this fashion, whether we have examined them or not. Having studied hundreds of thousands of animals and plants and found them all composed of cells, the theory is that we shall continue to find the familiar cellular organization as new organisms are examined. The term cell-theory is, like the term theory of gravitation, theoretical only when it is assumed that it will hold good elsewhere, or when analysis is pushed further and we theorize about underlying causes. No one disputes the existence of cells, or the assumption that they will be found as long as microscopes are used any more than he disputes the universality of gravitation because of which it is believed that stones fall when dropped from a height whether it be in California or Japan or on the planet Mars. There is, therefore, much common agreement regarding the existence of cells, and the agreement extends to many details of their structure and activity, as for example that all cells contain chromatin and that all cells have arisen from preexisting cells.

When it is said that the cell-theory meets with common acceptance, we mean that a host of trained observers have examined the microscopic structure of innumerable plant and animal bodies and found them composed of cells. Hence, 


\section{PHILOSOPHICAL AND PSYCHOLOGICAL ASPECTS 235}

there exists among competent scientists, a consensus of opinion which is formally known as the cell-theory; in other words a common sense in which this phrase is accepted. The only way this sense differs from the sense of persons without biological experience is that it rests upon wider and more critical observation and is, therefore, the more reliable. It happens that these conclusions regarding cells may be drawn only by persons trained to the use of microscopes; and only after special preparation of the materials examined, which is an illustration of what Huxley meant by trained and organized sense. It is not that the observations and conclusions involved are fundamentally different from those of everyday life. They are refinements of these, made possible by the training of the scientist and the organization of his material. There is no necromancy in science. Its methods are the logical methods of thought which normal individuals regularly use. Science has often made initial strides, through the work of investigators who perceived the unifying features in large groups of previously unrelated phenomena, and whose daring hypotheses at first resembled the flight of poetic imagination or the vision of some genius of the commercial world. But what has finally counted has been the confirmation of hypotheses step by step, until they have become commonplace knowledge verifiable by anyone who reviews the phenomena.

Another example may be given. Certain of the early embryologists defended the dictum, omne vivum ex ovo, as expressing the manner of generation; and later embryologists have extended this generalization, until we accept the statement that "every cell comes from a preëxisting cell." We mean by the modern statement of the older doctrine, that the facts have been recorded by earlier investigators and confirmed by later ones; that we have seen for ourselves the process of fertilization and development; and that our fellow workers are familiar with the phenomena, for they talk with us of what they have seen. Moreover, it is assumed 
that we shall see these processes again and again as observation is extended. Because the work is done by men who have spent years in study, the methods are by no means those of supermen, but only refinements of everyday work and thought. Here as elsewhere, there is plenty of common agreement and opportunity for verification of the simpler facts.

Refinement in the technique of analyzing phenomena thus constitutes the sole difference between the scientific and the popular method of drawing conclusions. In adjusting any mechanical device, one may be exercising a very common kind of sense. But it is a sense which differs from that exhibited by the scientific investigator, only in so far as the facts examined by the investigator are the more complicated and can be approached only after extended preparation. The man who builds a concrete sidewalk in his yard learns by experience and experiment, and by thinking things out as he goes. The investigator who is trying to advance our knowledge regarding the chemistry of cement, does essentially the same thing. Only he begins far ahead of the untrained man; and having a broader knowledge, he recognizes possibilities of error that the other does not comprehend.

The conclusion that we reach is, therefore, that there is nothing really unique in science or in the method of science. Scientists are not wizards, but men who apply to natural phenomena the methods of analysis used by logical minds in the affairs of daily life. The simpler facts of science can be shared by all who possess the training necessary for their apprehension. If the more complex facts are less commonly apprehended it is because they are complex and hence difficult of verification or subject to erroneous interpretation. Moreover, any normal person, who trains himself to examine the phenomena of nature, may be expected to subscribe to the common agreements as formulated by well established generalizations. If there is debatable ground 
and difference of opinion, it is because science no sooner gets a fact tolerably well established than it proceeds to other facts. While we agree upon the interpretation of certain data, conflicting data may be adduced at any time; or we may undertake entirely new lines of investigation, which for a time yield uncertain results. Having satisfied ourselves as to the general course of development in the individual, and having a common agreement regarding the same, we press on to something new, like the problems of fertilization and of differentiation. Here, we find ourselves upon ground where the facts are so sparsely established that we are unable, for the present, to discover a common-sense basis on which to formulate a theory. Divergent views exist in science only because the life of science is progress, and because science concerns itself with what is to be done rather than with what has been accomplished. Divergent opinions frequently eventuate in agreement as soon as the facts are known and established.

The function of the subjective process in the advancement of science now becomes clear. The fundamental classification of human thought is along the lines of subjective and objective reality. A so-called normative science like logic deals with the operations of the subjective element in its manipulation of facts and cannot of itself alone lead to new truth regarding a supposedly external reality, although it may discover more effective methods of handling the facts of sense-impression. The popular suspicion that the logician is merely juggling with words, even when his methods are sound, seems to rest upon conviction that the technique of reasoning is no more than a tool and therefore subordinate to the material upon which it works. Belief that the human mind can obtain knowledge of any so-called external or objective reality, by means that are wholly subjective, is repugnant to the thought of natural science as well as to the common sense of mankind. 


\section{SCIENTIFIC LAWS AND SCIENTIFIC TRUTH}

Scientific laws might better be termed generalizations, because they are merely formulations of experience. The use of the term law is misleading, if it results in belief that scientific laws must be regarded as established by some agency. In primitive times, the laws of social custom were believed to have had divine origin; and later, civil laws were known to be established by men. Hence, the popular connotation of law is that of a rule, established by some power, and which must be obeyed. By analogy, the laws of nature are regarded as principles established for the guidance of the universe. Nature thus appears to act under a sort of legal necessity, whereas the fact is that we merely have so constantly or so definitely observed certain sequences and complexes of inter-relationship that we feel certain they will reappear under similar circumstances. It is extremely difficult to escape the idea of necessity in the case of the relationship which is designated cause and effect. But even here scientific analysis reveals no necessity, beyond the relationship between phenomena which has been observed in so definite a fashion that the cause may be presumed always to be followed by its effect. A law in natural science is a short-hand method of describing the probable order of phenomena. In general, such laws are regarded by scientists as discovered relationships, not as agencies which force nature to move in particular directions.

It is true that science holds the hypothesis of adequate causation as the most fundamental tenet of its faith. The reply of science to the claim that "the day of miracles has passed" is that there never was a day of miracles, since every phenomenon has its adequate cause. Nevertheless, the exact basis of the certainties called scientific laws should be held in mind. It might be stated in this wise: Suppose the present represents the middle of time. There is no other way of regarding the present, because time must be thought 
of as extending indefinitely into both past and future. Suppose that a human mind could know all that had ever happened in the past. One would then know only one-half of the possibilities, because there would be as much time, and therefore experience, yet to come. At most, one's assumption that what had always happened would continue to happen could rest only upon what might be termed a fifty per cent experience of the possibilities. Granted that far less certainty than this is good enough for practical purposes, the theoretical situation is worth bearing in mind.

To pursue the matter further, the difference between a coincidence and a law of nature is perhaps not so fundamental as is supposed. In the case of a coincidence, there is an association of phenomena sufficiently unusual to attract attention. In the case of a scientific law, we have seen certain phenomena associated so frequently or in such a definite relationship that we have been led to assume their invariable association in the future. There is no necessity for the continuance of a given association beyond the fact that it has been always so observed or that the definiteness of the relationship makes even a single case appear conclusive. Thus, if you saw a red headed man on a white horse you would think nothing of the circumstance. If you saw another such combination a block further on, you might notice the coincidence. If you saw one at every corner, you would begin to suspect that it was not a mere coincidence but a constant relationship. And if you had never seen white horses without red haired men on their backs and always at street inter'sections, you would elevate this grouping of related phenomena to the level of a fact, established by scientific observation and to be expected in the future, just as one expects present-day birds to have feathers and beaks. When so formulated as to state its assumed occurrence for the past, present, and future, such a fact or group of facts would become a law of science.

The foregoing illustration is drawn from the field of 
relationship that is called classification. The case is not otherwise when the law involves the relationship of sequence, as determined by experiment. Thus, experiments may determine that certain phenomena are to be recorded by the series 2-4-6-8-10 and so forth. ${ }^{4}$ Here again, one observes a certain grouping of the phenomena. The serial feature introduces a more definite time or space element and a greater complexity of inter-relationship, but it is not clear that it alters the underlying situation. Scientific laws are not a kind of primæval legislative enactment to which nature must conform, they are merely formulations of observed relationships. If we would cease to speak of them as laws, and call them generalizations, certain unwarranted implications would cease to encumber the philosophy of science.

Again, the scientist has come to realize that, in the case of complex phenomena, what he regards, as truth at any particular time may not be final. Like every one else, he tends to believe truth as permanently established, when the tests of science have been exhaustively applied to a particular interpretation of a group of phenomena. If the case be one of comparative simplicity, there is strong presumption in favor of the finality of such an interpretation. But all that is meant when we say anything is true, is that, with our present knowledge, a certain timely statement can be made. Such a conditional statement is the truth at any given moment. If, at a subsequent time, new facts necessitate reformulations, we then say the truth is quite different from what we once thought it to be; and this new statement may in its turn be changed or replaced.

Thus, what is held to be true by one generation may not

${ }^{4}$ The discovery of a multitude of serial relationships in which one term of the series is a function of what follows seems to be the most distinct advance made by modern science over the scientific method of ancient times. In Greek science the classificatory relationship $A<_{\mathrm{C}}^{\mathrm{B}}$, was comprehended, but the functional relationship was obseure. It is this functional relationship which so reinforces the idea of necessity in causation. 
be held true by the next; because we designate as true that which holds with the data available at a given time. By this test, the Ptolemaic system in astronomy was truth for the time being. Although later replaced by another concept, Aristotle's explanation of respiration, as a means of cooling the blood, was a good one for the knowledge of the period and hence could be regarded as true in its day. Absolute truth may be attainable, may, indeed, have been attained in some instances. But when men believe that they have arrived at finality in truth they get into trouble and when the scientist thinks any truth is established for all time, science is in danger of ossification. Scientists need to tell themselves that their truths are working hypotheses and that truths which seem firmly established may some day be overturned. It is a fact that the simpler truths established by science regarding natural phenomena are more certain than anything else within the objective field. Nevertheless, the truth in science must always be held open to extension or modification, if not to complete replacement. 


\section{CHAPTER X}

\section{THE NATURE AND MEANING OF SCIENTIFIC RESEARCH ${ }^{1}$}

THERE is an exhortation, supposedly epitomizing the wisdom of practical life: "Don't waste your time speculating on why black hens lay white eggs. Get the egg." This is, perhaps, good advice in business affairs, and appeals to many as a sensible doctrine. Yet the most cursory survey of the progress of civilization will show that the men, who have done most for the world in a practical way, have often been those who have speculated on just such problems-and who have solved them. To-day, the man who gets the most eggs is he who in breeding and rearing his poultry follows the methods established by the scientific study of heredity, of selection, and of general physiology. And it is worth remembering that the workers who established the more important of these facts, were not lured to their work by the prospect of financial gain, but grappled with scientific problems because of a conviction that knowledge of such matters was worth while, and in the long run indispensable to human welfare.

If we analyze the getting of eggs, as it goes on in the varied activities of our modern world, we find that industry is everywhere rooted in the facts of science. Not uncommonly, whole fields of commercial enterprise go back to some simple but fundamental scientific generalization. Thus, the canning industry is founded upon what the biologist terms biogenesis or the fact that no life arises save from preëxisting life. Since putrefaction is an incident of the

1 The material which appears in this chapter is substantially the same as that used in a lecture at Oberlin College in January, 1913, and later published in the American Museum Journal, Vol. XVIII, No. 7, 1918. 
growth of microscopic life in organic materials, there can be no putrefaction where all living germs have been destroyed, by heat or other means, and where new germs cannot obtain access. The chemical processes which underlie so many industries have all been built upon the fundamental theory of chemical combination, which was elaborated during the latter half of the eighteenth and the first half of the nineteenth century. The generalizations of physical science regarding the indestructibility of matter and energy are similarly important.

We all recognize with Leonardo, that "science gives certainty and science gives power." We also recognize that only by painstaking effort can scientific knowledge be obtained. We commonly fail to recognize the nature of the scientific studies which have preceded the discovery of many facts applicable to our daily lives. The scientific discoveries of the past constitute the foundations of life in civilized communities as well as of modern industry; and the scientific discoveries of the present will, if we do our share, be as vital in the lives of future generations. We should eliminate from our minds the terms pure and applied science. This distinction is a false one, because no line of separation exists. On every hand, discoveries of a theoretical and general nature are of practical value; and, conversely, practical achievements are a continual stimulus to further investigations along theoretical lines. These in turn influence practice in new and wholly unexpected ways.

Any research that promises substantial additions to knowledge is worth doing in the present, because in the past such work has often yielded results undreamed of at its inception. The history of science urges us to the continuation of theoretical and non-utilitarian investigation in the present, however much we may be tempted to press the more obviously utilitarian lines of study. Research along lines immediately useful will take care of itself, for we are all convinced that it is worth while. But where the immediate 
return is not in evidence, it requires a certain faith in the final outcome, which can only be held by those who know what has happened again and again in the past.

It is, therefore, important that scientists emphasize what is called pure research. Scientific men have not made the importance of this item of their creed sufficiently clear to those who are not scientists. They should preach to the public as well as to their fellows the need for investigation unhampered by utilitarian demands. The oneness of scientific study should be emphasized, to the end that all may understand how science advances and all may live in the faith that knowledge of natural phenomena is worth more than it costs to discover.

There is small danger that we shall fail to appreciate practical research-how to grow thirty bushels of wheat where ten grew before or how to produce a new antitoxin. But there is danger that we may fail to see the other side, that the men capable of doing creative work as investigators may be unable to find a livelihood; and that in the present, as in the past, the advance of science may depend too largely upon the chance meeting of brains and means. To show that this danger is real, not imaginary, it may be said that in zoölogical science there are, in the United States to-day, relatively few positions in which a young man of promise may earn a living in pure science. He may teach, with some chance for investigation, or he may find limited opportunities in the applied zoölogy of government or state service or of commercial enterprise. But for the man who gives promise of being competent to do the pioneering demanded by pure science, there is almost no opportunity for a living. A like condition obtains in many other scientific lines and this failure to provide opportunity for the worker of promise is a reflection upon our civilization; for we are drying up the springs which feed the fountain, and the extent of the loss is incalculable. ${ }^{2}$

${ }^{2}$ Since these paragraphs were written the National Research Council has 
Conspicuous ability as an investigator is comparatively rare and every effort should be made to discover the men who give promise of such attainment. When found, they should have their chance, should be given clearance papers for a voyage into the unknown. Men who have this ability, who, standing upon the ground already mapped, can see the distant mountains, and whose imagination pictures the path across the intervening valleys and deserts, are like the explorers of a virgin continent; they "yearn beyond the skyline where the strange roads go down." The human race has emerged from barbarism because the desire for knowledge has impelled men of this adventurous spirit, in spite of discouragement and misunderstanding, persecution and death, to search after the facts of science in what is for man the last "dark continent"- the realm of nature:

"We were dreamers, dreaming greatly, in the man-stifled town;

We yearned beyond the sky-line where the strange roads go down.

Came the Whisper, came the Vision, came the Power with the Need,

Till the Soil that is not man's soul was lent us to lead."

This stanza of Kipling will serve to enforce the analogy between the "nature-searcher" and the explorer which we shall here develop. It shows also that modern science has not destroyed the opportunity for imagination. For, though "the old order changeth," there remains in our thinking that which brings the emotional appeal of lofty imaginings; for here indeed, man does contend with gods and strives to wrest from them the knowledge that shall make his future more secure.

The history of almost any line of scientific investigation come into being. One of the encouraging possibilities of this organization is its emphasis of research as a profession demanding adequate recognition. 
will, if traced back, afford illustrations of the value of pure research. For the purpose of illustrating what has happened again and again, several representative cases may now be elaborated.

\section{DEVELOPMENT OF KNOWLEDGE REGARDING MICROÖRGANISMS}

By means of this illustration, we propose to show: that facts now recognized as of life-and-death importance for the whole civilized world, had their beginnings in investigations which were of questionable value when judged by the utilitarian standards of the past; and further, that society might profit by this bit of history and assume a more farsighted policy in dealing with scientific investigation in the present.

That many diseases are caused by minute organisms, living as parasites within the bodies of animals and plants, and so producing the derangements called disease, is a fact made familiar during recent years. It is also well known that progress in the discovery of germs hitherto unrecognized, of antitoxins, of vaccines, and the like is saving the lives of millions. At the present day, diphtheria is no longer the dangerous and often fatal disease it was even twenty years ago. If we take the precautions already well tested, there is no danger that yellow fever will again scourge our gulf cities, or bubonic plague devastate Europe and America as it still devastates the Orient. We have conquered typhoid fever, at least in cases of local epidemics or where large bodies of men are sent into dangerous territory, and no man can foresee where such control of disease will end.

These are familiar facts. The steps by which the mastery has been attained are less well known. We take this mastery as a matter of course, without understanding the historical development of the knowledge which now means life or death. It is true one may be familiar with the most recent chapters, as heralded in the newspapers and current mag- 
azines, when an antitoxin for diphtheria or a method of preventing typhoid fever has been announced. But these are only the recent pages of a book long in the making, to find the title page of which we must turn back through many years and to matters having little apparent connection with what is now before us.

To illustrate this last statement, let us trace the course of man's discoveries regarding the microörganisms, taking as a convenient starting point the year (1676) when the Hollander, Anthony van Leeuwenhoek, discovered with the microscope, but lately come into use as a toy and source of amusement, what he described as "little animals observed in rain, well, sea, and snow water as also in water wherein pepper had lain infused." 3 Leeuwenhoek's discoveries were no doubt regarded as useless by his contemporaries, save a few by whom his work was highly esteemed. The possession of a modest income enabled him to devote a generous portion of his time to study; and at the end of a long life he had examined with his microscope all he could lay hands upon in both animate and inanimate nature. Among other things, he discovered some of the larger bacteria, many protozoa, the passage of blood from arteries to veins through the capillaries (the one link needed to complete Harvey's evidence for circulation); and he was the first to describe, if not the discoverer of, the human spermatozoön. ${ }^{4}$

$\mathrm{He}$ became the first great microscopist. Thus at first:

\footnotetext{
"We were dreamers, dreaming greatly, in the man-stifled town;

We yearned beyond the sky-line where

the strange roads go down."
}

${ }^{3}$ See: Kent, W. Sayville, "Manual of the Infusoria," for quotations from, and an account of, the work of Leeuwenhoek.

${ }^{4}$ Interesting facts regarding the life and work of Leeuwenhoek will be found in the article by D. F. Harris, "Anthony van Leeuwenhoek the First Bacteriologist," Scientific Monthly, Feb., 1921. Cf. also: Locy, "Biology and its Makerz." 
Despite crude and imperfect microscopes, knowledge of these animalcules grew apace, and during the eighteenth century the more important types were recognized. Their discovery reopened the discussion of spontaneous generation, which, a few years before Leeuwenhoek's first observations, had been discredited in the case of insects and the larger organisms. The conflict was renewed between the opposing forces. During this struggle facts were established which not only aided in the final triumph of the modern theory of biogenesis, but also resulted in extensions of knowledge useful in other directions.

With the advent of the cell-theory in 1839 and with marked improvements in the microscope, the distinction between multicellular and unicellular organisms was established. Finally, the age-long controversy was closed by: Pasteur, in his studies upon disease and fermentation; Tyndall in his examination of the floating matter of the air; Dallinger and Drysdale, who first observed the complete life-cycle of a protozoön; and a host of others. And here, these "nature searchers," who since the days of Leeuwenhoek had been pressing their forces into the seemingly useless fields that teemed with microscopic life, joined with the men long baffled in their fight for human lives, and gave to medicine the support needed in reaching the vantage ground from which to discover a new horizon-line in the germ-theory of disease.

For a long time, physicians had known that diseases were catching. "The pestilence that walketh in darkness," was no idle figure of speech. An analogy between the spread of disease and the spread of living organisms had been pointed out for centuries. But only in the nineteenth century, in the generations of our fathers and grandfathers, did the medical men, aided by the investigators who had ventured into the wider domain of abstract science, show that the germ is so truly the cause of infectious disease that without the microcroscopic germ the disease does not exist. ${ }^{5}$ Since the firm

${ }^{5}$ First-hand contact with the medical discussion of this period may be ob- 
establishment of this germ-theory, now the germ-fact of disease, investigations in this direction have received increasing support; until in recent years we have seen the establishment of several institutions for general medical investigation, such as the Rockefeller Institute in New York City and the State Cancer Laboratory in Buffalo. So immediate have been the results, we may well believe that laboratories of this character are destined in the near future to be generously supported by public and private funds.

The fact of most importance, however, is that these recent triumphs in an applied science had their beginnings in the days of Leeuwenhoek. He was the first of a host of investigators in this field, who did not consider the immediate utilitarian values of what they sought. These men persevered in the belief that all facts of nature are worth while and lived and died in the faith that somehow, sometime, the facts they established would find a place in man's scheme of the universe.

"Then the wood failed-then the food failedthen the last water dried-

In the faith of little children we lay down and died."

Did our space allow, we could follow this history in more detail; we could show that the more important of the earlier workers were students in pure science, attempting to make what were termed in the earlier days "Contributions to Knowledge"; that the long fight over the question of spontaneous generation was for centuries only an abstract and academic matter, of no seeming value in everyday affairs; that the burden of this pioneer work was borne by men who were given scant public assistance and little recognition, who followed no path of least resistance.

tained in Oliver Wendell Holmes' essay upon "Puerperal Fever," written in 1843. This is a medical classic and has the advantage of being found in almost every library. 

"On the sand-drift-on the veldt-side- in the fern-scrub we lay,
That our sons might follow after
by the bones on the way."

The lesson is plain. Are we in this day of enlightenment doing much better by the workers in pure science? We hail extravagantly the successful investigator in applied science and he is well rewarded; though what he receives is insignificant compared with that allowed to swashbuckling captains of industry. But we do not provide for the man of promise in abstract science a chance to keep at his work, in the hope that he may make real contributions to knowledge. We are greedy over the finished commercial product, while we turn out, to starve or teach, the young men among whom the Leeuwenhoeks of some future science must be found. The conclusion is that our civilization though made possible by the control of nature which science has brought, is not offering adequate opportunity for further investigation. We are neglecting that which might lead to things as undreamed of as was the germ-theory of disease, when Anthony van Leeuwenhoek discovered in 1676 "certain little animals in rain, well, sea, and snow water and also in water wherein pepper had lain infused."

\section{LIFE-CYCLE OF THE FRESH-WATER MUSSEL}

The life-cycle of the fresh-water mussel further illustrates the nature and importance of research in science. First, because the details of this unique life-history were discovered after years of study by those adventurers of science who struck into the hinterland of nature, where lay no beaten trails; and second, because the facts, established in this earlier period and with no utilitarian aim, have during the past twenty years been turned to account in commercial enterprise. We find here an illustration of the discovery of 

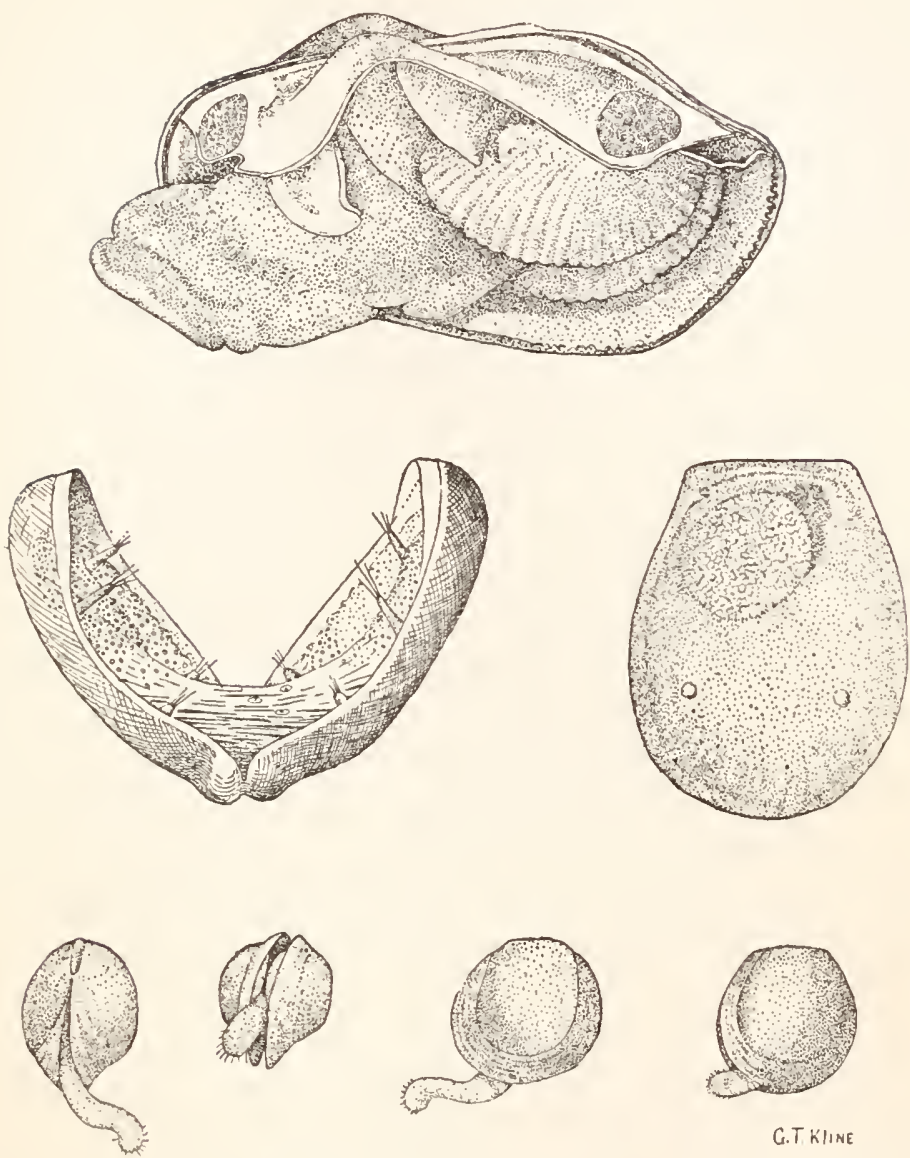

G.T KIINE

FIg. 28. Fresh-water Mussel, Lampsilis subrostrata, and Developmental Stages. Above, the gravid female showing fan-shaped brood-pouches (a portion of outer gill). Middle, side and end views of the glochidium larva greatly magnified. Many thousands of these larvæ would be found in each brood-pouch. The groups of hair-like projections on the figure to right are sensory organs. The fibres of the muscle by which the valves of the glochidial shell are clamped upon the gill filament of a fish appear at the bottom. Below, four views of a young Lampsilis which has recently begun life upon the bottom after its parasitism on the fish. The outline of the glochidial stage is still seen upon the shell which is growing rapidly. The animal moves actively by means of the "foot" which is thrust from between the valves of the shell. (After Lefevre and Curtis.) 
economic values in a field originally explored without this incentive.

Briefly, the life-cycle of the mussel, as illustrated by Figs. 28, 29, and 30, may be summarized as follows: The sexes are separate, the spermatozoa are discharged freely into the water, entering the body of the female with the
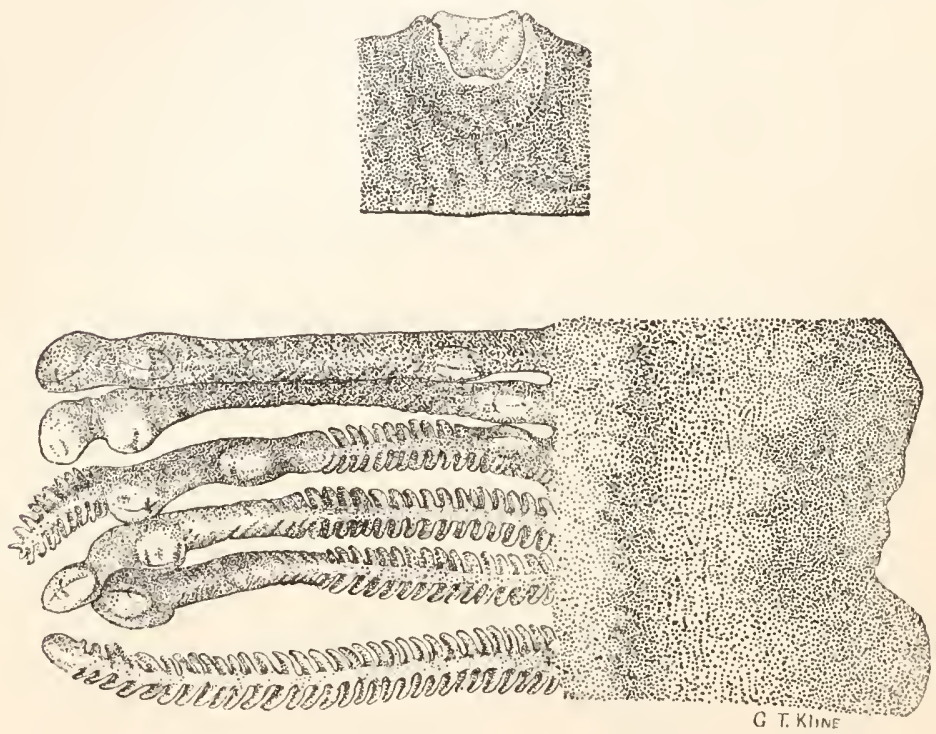

FIg. 29. Glochidia of Lampsilis on Gill Filaments of a Fish. Above, small portion of a filament with single glochidium partially overgrown thirty minutes after original attachment. Below, small portion of a gill showing several filaments heavily infected with glochidia, which are now completely overgrown by the gill tissue. At moderate temperatures such glochidia complete their parasitism in from three to four weeks. (After Leferre and Curtis.)

respiratory water currents and there fertilizing the eggs contained in brood-pouches which are formed by a modification of the gills. Development now begins and continues until a larval stage, known as the Glochidium, is reached. In this state the young are discharged from the female. The glochidium, which in size is near the limit of visibility for the unaided eye, now rests upon the bottom and must perish 
before many days unless it is accidentally brought into contact with a fish. In this event, it fastens itself upon a fin or gill of the fish, causes a growth of the fish's epithelium and, in the course of a few hours, is completely enclosed within the tissues of its host. Thus securely placed, it undergoes development to a stage in which it is able to assume the life

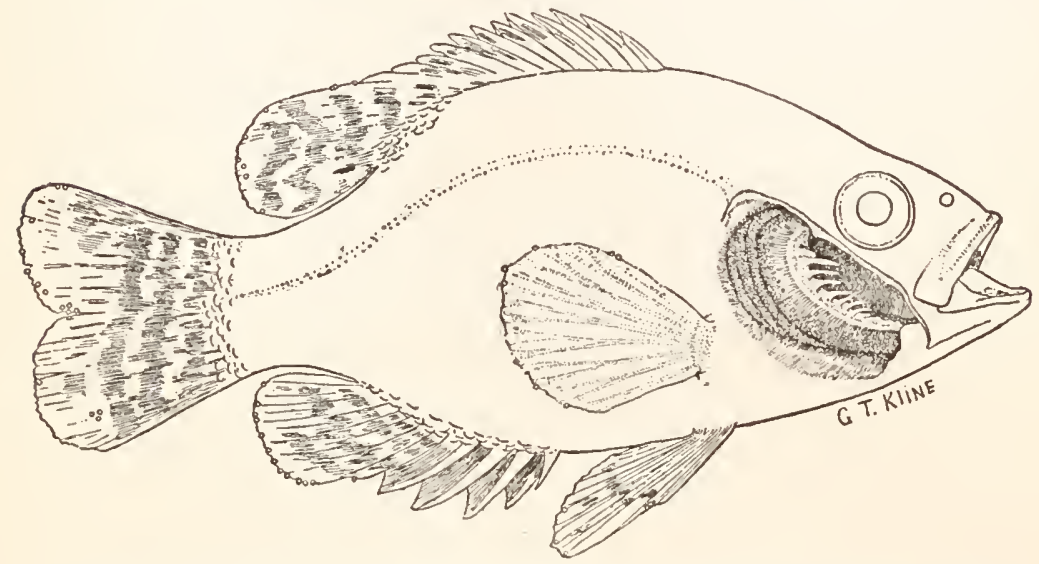

Fig. 30. Rock-bass (Ambloplites rupestris) about five inches in length, infected with glochidia of Lampsilis ligamentina. About 2,500 were successfully carried through the metamorphosis by each fish in this infection. Note the large number on the gills and the small number on fins. (After Lefevre and Curtis.)

of the parent mussel. It then drops from the fish and takes up an existence upon the bottom which it continues throughout life. Two points are of importance in this cycle. First, the glochidium is a stage at which development ceases and death ensues, unless the larva becomes attached as a parasite upon a fish. Secondly, the gaining of this favorable environment within the fish's tissues is wholly accidental; and so many glochidia perish without so doing, they must be produced in enormous numbers in order that the chances of destruction be overcome and the continuance of the species assured.

When we examine the paths followed in the establishment of the facts above outlined, it so happens that the trail 
again begins with Leeuwenhoek. Before his day it was not even known whether there existed in lowly organisms like these mollusca anything comparable to the maleness and femaleness recognized in higher forms. Their whole mode of generation, whether spontaneous or by means of eggs, was a matter of theoretical dispute. In his efforts to solve these fundamental, but at the time wholly academic, questions, Leeuwenhoek turned his microscope upon the fresh-water mussels and discovered the innumerable eggs and larvæ which crowd the brood-pouches of the females. These he correctly interpreted as the young of the mussel in which they were found; and it is clear from his descriptions that he saw enough of their development to justify his conclusion that mussels, like the more familiar forms of animal life, arose from eggs.

In the subsequent advance of our knowledge two periods are conspicuous, one marked by a mistaken hypothesis, the other by the discovery of the parasitism. The first period (1797 to about 1830) was ushered in when the failure to secure stages beyond the glochidium led to the so-called Glochidium-Theory, which maintained that the larvæ were not the young of the mussel from which they were obtained but a wholly different species of bivalve living within the mussel as a parasite. This theory had the negative advantage of an incorrect hypothesis, it aroused opposition and called forth investigations which showed once for all that the glochidium was the young of the mussel in whose broodpouch it occurred. ${ }^{6}$

The collapse of the glochidium-theory left the subsequent stages, by which the larvæ reach the condition of miniature adults, an unmapped territory where all trails went blind. Not until 1866, when a young German investigator, Leydig,

${ }^{6}$ In passing, it is of interest that the word Glochidium, by which we still designate these larvæ, had its origin at the period when the supposed parasites were described as a species parasitic upon the mussel and named Glochidium parasiticum. 
made the somewhat accidental observation of glochidia living as parasites upon fishes, was the clew discovered and the work of following the later stages made possible. ${ }^{7}$ During this final period, the post-glochidial development became well known and the earliest stages of egg and embryo were reëxamined in the interests of fundamental research upon derelopment. Most significant of all in illustration of the importance of abstract research, is the fact that from Leeuwenhoek's beginning, all this work was part of an attempt to understand the nature of individual development. It was in no sense directed toward utilitarian ends. Originally, it was a question of the mode of generation, whether spontaneous or by eggs and sperms. Later, it became a question of comparative embryology and the tracing of each organ in the body back to the cell or group of cells from which it originated. Through it all, the direct pressure of utilitarian considerations is nowhere to be found; but rather a belief by the investigator's that the facts were worth linowing, because they gave a broader horizon to the landscape of nature.

In 1891 the first pearl button was cut from a fresh-water mussel shell. The business soon became a substantial industry and within ten years the destruction of the mussel beds in the Mississippi River seemed imminent. At the request of the manufacturers, the United States Bureau of Fisheries undertook a brief survey and offered some wholesome advice, all of which was disregarded with the opening of new sources of supply in Arkansas, Indiana, and along the Ohio. Seven years later, under the stress of a still diminishing supply, the manufacturers again approached the Bureau of Fisheries, with the result that the Bureau made an extensive study of the mussel, having in view its artificial propagation. The results of this investigation have been brought together; ${ }^{8}$ and, since there are still many funda-

'Leydig, F., "Mittheilung über den Parasitismus junger Unioniden an Fischen in Noll." Tübingen, Inaug, Dis. Frankfort a. M., 1866.

${ }^{8}$ Lefevre, G., and Curtis, WV. C., "Studies on the Reproduction and Artifi- 
mental questions involved, the federal government has constructed, at Fairport, Iowa, a station for the investigation of these and all other problems of fresh-water biology, and as a part of this station, a hatchery for the rearing of mussels by artificial means. ${ }^{9}$

Although much remains to be done before the rearing of the button mussels is established upon a commercial basis, the results are encouraging and it may be hoped that before many years the supply of raw material will be drawn from beds artificially produced and maintained. As this work in applied science advances, it is conceivable that the men who have dealt with these practical problems may win popular recognition greater than that given to any of their predecessors during the two hundred and fifty years since Leeuwenhoek. Be this as it may, it is to the earlier workers that the larger measure of credit belongs; for theirs was the more unique attainment. Between the two is the difference between the men who broaden a beaten trail and those who penetrate territory wholly new.

\section{THE PROGRESS OF KNOWLEDGE CONCERNING HEREDITY}

The problem of heredity is our final illustration of the relation between theoretical and practical knowledge in the history of science. In this field we have known so little, have so failed in the discovery of land-marks until very recent years, that biological science is only beginning to get its bearings and to hew its way into the wild. We to-day stand

cial Propagation of Fresh-water Mussels." Bulletin Bureau of Fisheries, Vol. XXX, 1910. See also: the miscellaneous papers by other investigators, published in Bull. Bur. Fisheries since 1910; and particularly, Coker, R. E. et al. "Natural History and Propagation of Fresh-water Mussels," Bull. Bur. Fisheries, Vol. XXXVII, 1919-20.

${ }^{9}$ This station, which is probably the most extensive establishment of its kind in the world, is described briefly by R. S. Coker, "The Fisheries Biological Station at Fairport, Iowa." App. I, Rept. U. S. Commissioner of Fisheries, 1920. 
like those who have just effected a landing upon a new continent, whose supply camps are established, whose ax-men are out, and who are beginning the march. This is a field of investigation where discoveries are so new that men have not yet grasped their importance nor set the facts to work in ways to suit their needs. This is a problem of the future, and as sucl appeals more strongly to imagination.

The fact of hereditary resemblance must have been recognized since man first gave attention to the breeding of domesticated animals, or first saw that his offspring were like himself. But heredity remained rather the plaything of the philosopher than the problem of the scientist, until the manner of individual generation had become established and the germ-cells recognized as its physical basis. All the earlier work upon reproduction and development, all the investigations which centered around the discussion of spontaneous generation, all the studies which led to the cell-theory were necessary to establish our present position, and to give the modern investigation of heredity its point of departure. With these things behind it, heredity has become a subject of prime interest in present-day biology, and only in the last quarter century has our attack begun.

Two men stand out as pioneers of the recent advanceGregor Mendel, whose work was the earlier done but the later known; and Francis Galton, who should be credited with collecting valuable data and with arousing public interest by his eugenic propaganda, although his laws of heredity now seems of small value.

Without attempting an explanation of either the Galtonian or the Mendelian theory of heredity, a word may be said in illustration of an essential difference between the two. ${ }^{10}$ Most of us are familiar with the tables, published by insurance companies and stating the expectation of life for a man at a given age. You are, say thirty years old. The table

${ }^{10}$ The cellular aspects of Mendelian heredity have been briefly discussed in Chapter VII, pp. 130-44. 
says you may expect to live until you are sixty-four. This is well so far as it goes. It is comforting to feel one has that much lease on life, even though his life is almost half spent. And this knowledge does very well for life insurance companies, since it can be applied to thousands of policy holders with a degree of certainty that places the whole superstructure of the insurance business upon a stable foundation. In your particular case, however, this kind of certainty is not satisfying, since it can tell you nothing of your own or any other individual's duration of life. Though you die to-morrow or live to be a hundred, your life merely counts as one item in the statistics upon which such tables are based.

The insurance tables, therefore, allow us to make prophecies for populations, but not for individuals, and this is essentially the nature of Galton's law of heredity. It attempts to say what will be the inheritance on the average, but leaves us in the dark as to what will happen in the individual case. If, on the other hand, the life insurance company were able, after looking you over, to say that, barring death by accident, you would become an octogenarian, or to say that inability to resist disease would cut you off at forty, then we should have the kind of prophecy it is possible to make in cases of Mendelian inheritance which have been thoroughly investigated. For here, we can, by proper testing of the individual, foretell the characters he will transmit to his descendants. Galton's law is then of value as a statistical statement, but as a guide in the fundamental analysis of heredity it can scarce be compared with the law of Mendel.

The discovery of the Mendelian phenomena, like most important advances in the science of biology, was not the result of any feverish search for utilitarian values. Mendel's interests were along theoretical lines. The account of his experiments remained buried in an obscure publication, until after the same phenomena had been rediscovered by later workers about 1900. And now, less than a quarter of 
a century later, Mendelism is becoming a household word. So many facts have already been accumulated and so revolutionary are some of its conceptions, that we begin to doubt whether our other theories of heredity have had any value whatsoever. And we look forward with hope, because we are at last upon firm ground and have found a way of advance.

The results which must inevitably flow from the obscure beginning made by Mendel are not easily appreciated, so great is the importance to mankind of accurate knowledge, and hence control, of heredity. Already the breeding of domestic animals is feeling the impetus, and the superstitions that have clouded the efforts of practical breeders are becoming things of the past. The breeder of animals who would have large success from now on, must be not only biologically trained; he must know every twist and turn of the latest Mendelian formulæ. For the same laws hold good in many different animals and plants, in the wool of sheep and in the colors of flowers. Breeding will soon become an exact science, demanding extensive biological training and a thorough knowledge of the short-hand terminology which the Mendelian worker has devised for the visualizing of his complex phenomena.

For the human race, we may eventually breed better men. Though, of course, the time is far distant when any selective mating will be possible, save as we develop a social tradition that makes us feel disgraced if we marry where the stock is clearly defective, and save as we enforce a rigorous prohibition of the right which conspicuously defective individuals now have to inflict their full quota of descendants upon society. These things will come slowly, for the social organization is discouragingly stable, and we cannot be oversanguine when we contemplate the attainment of perfection at some future period. As Huxley puts it, "If the temperature of space presented no obstacle, I should be glad to entertain this idea of ultimate human perfection; but judg- 
ing from the past progress of our species, I am afraid that the globe will have cooled down so far, before the advent of this natural millennium, that we shall be, at best, perfected Esquimaux."

For practical purposes, however, it is encouraging that man may improve his condition in the course of a century or so, a thing we obviously do accomplish in some degree. And we may expect material advance in the near future, if we do no more than prohibit what is clearly bad, while giving social approbation to the kind of matings which make for better men. But shall we stop here once we recognize the facts? We have given up, among individuals if not among nations, the cherished right to knock the other fellow on the head if he disagrees with us; and the type of mind which desires progress rather than precedent believes that the future will see the surrender or restriction of other rights now regarded as fundamental. It may even come to this matter of marriage and giving in marriage. Already we are making the attempt to prevent hereditarily defective individuals from reproducing their kind, something we can accomplish only when the facts of heredity are fully known for these particular cases. Moreover, eugenic propaganda lead the thoughtful and conscientious members of society to consider their obligations in the light of heredity.

When we really get beyond the present sky-line we shall do more than this; for the future will demand better brain and more of it than the past, and a sound body to go with the better brain. It has been said that "the rulers of the world have been big eaters"; which is probably true, in so far as those who hold their fellow-men effectively in hand are, commonly, men and women of some brute-force. One might say, as the converse of this, that the thinkers of the world are below the average in physical attainment. For, while it cannot be stated accurately, it seems clear that nature exacts heavy penalties for too much intellectual effort, and that for most of the race physical toil, even though 
arduous, is still the most wholesome of all activities. How to realize the old Greek ideal of the sane mind in the healthy body is still afar off. Present results indicate that heredity, and not environment or education, leads to permanent progress. If this is so, the application of the facts of heredity to our species will be one of the great problems of the future. We see now that we are on the right track, and that an adequate knowledge, and hence control, of heredity may be possible sooner than we had thought.

Returning to the main contention, what we have seen in the history of man's study of the microörganisms, in a more restricted case like the fresh-water mussel, and in the broad field of heredity, will be found in other lines. Facts apparently remote from present needs come to be the very life blood of subsequent generations. There are, doubtless, barren fields, but almost any facts of nature are worth studying, since only by continuous searching do we find that for which we seek. If a child is lost on a mountain and there are searching parties out beating the bushes, now here, now there, or systematically covering the ground, the one who actually finds the child may be rewarded; when in reality it is largely an accident that he rather than another succeeded in the quest. It is more than likely the credit belongs to another who so organized the hunt that nothing could be overlooked. In our quest for facts, we must so advance that no spot is left wholly unexplored; for we cannot tell what importance any part of the field may assume. We cannot afford to concern ourselves to-day merely with what seems useful, since the more important advances of the past have commonly been made through fields which at first gave small promise of value.

To some extent the needs of practical life have induced men to explore the unknown territory of nature. But to a greater extent investigators have been led into this territory by their attempts to learn more of nature, irrespective of utilitarian values. We should, therefore, spare no effort 
to make such investigations possible. The recent history of science indicates that a larger amount of research is now in progress, "where the strange roads go down," than at any time in the past, and that the more important part of this work is being pursued without the incentive of financial gain. In the face of the very general failure to appreciate this situation, the scientist should consider the means to a better understanding. The case should be presented in a way to make men understand that pure science is not "just a lot of this bug business," as is sometimes said of zoölogy, but a "man's job," which appeals to imagination and which taxes to their limit the intellectual resources of mankind-a task we must take up where our forebears lay it down. That to conclude our analogy:

"Follow after-we are waiting,

by the trails that we lost

For the sound of many footsteps,

for the tread of a host.

Follow after-follow after-

for the harvest is sown:

By the bones about the wayside

ye shall come to your own!" 


\section{CHAPTER XI}

\section{THE RÔLE OF SCIENCE IN THE SOLUTION OF SOCIAL PROBLEMS}

ACCEPTING the broad definition of science, as the product of human rationality applied to the phenomena of nature, it is possible to claim for science a larger place in the affairs of men than could otherwise be maintained. What men call civilized society with its material surroundings, its industrial, political, and social institutions, its state of mind that makes civilization a possibility, has arisen as the collective product of human ideas acting upon the human and the material environment. This vast complex is ultimately a product of individual human minds reacting to their world of persons and things. The first steps were, of course, wholly unconscious. As civilization became established, occasional thinkers began to understand the significance of rationality in the control of environment. In later times, an increasing number have apprehended human social organization as a process in space and time, have sought to ascertain the end toward which it has progressed, and have considered the extent to which man can assume direction of its progress in the future. As a result of the analyses made by such philosopher-historians as Guizot, Buckle, Comte, Carlyle, Spencer, Hegel, and others, it seems fair to say that the end toward which civilization has blindly directed its main effort is the elevation and expansion of the individual. In the advancement of civilization through the action of the human mind upon its environment, no one factor, such as religion or science or hero-worship, can be regarded as allimportant. But in so far as it is definable as the rational attack upon phenomena, science holds a unique position. 
In view of the definition of science above given, we understand why the scientist does not accept the naive formulas, by which the progress of society is frequently explained, for example, belief that the advances of western nations, during the past nineteen hundred years has been mainly a function of the dominant religion. The spirit of the greatest of ethical masters is in no small measure responsible, but the progress of western culture is a more complex affair.

Acceptance of the traditional explanations of progress would be unimportant, if such an attitude did not lead to blindness in situations which involve the future of mankind. We must have in mind the entire situation-must consider all the data. When this is done, the rational processes of the mind, which constitute the motive power of science, appear as a dynamic factor in human progress. Behind the life of the civilized community, with its elevation and expansion of the individual, is the driving force of rationality.

\section{THE MATERIAL FOUNDATIONS OF SOCIAL WELL-BEING}

Whether or not it be agreed that the development of the individual to the limits of his capacity constitutes the goal of human effort, it is fairly obvious that human progress from the Renaissance onward has proceeded in this direction. The modern Utopia seems to be a world in which men will not be debarred from a realization of the best that is in them, save by the obligation to give to others an equal opportunity. We are far from the goal, but enough has been effected that we may dream of a day when no human individual will lack the opportunity to achieve, both physically and mentally, the best that lies within him. Equality of capacity would seem a biological impossibility, but equality of opportunity is not unattainable within reasonable limits. It is this upward surge of individuality that has produced the democratic movements of the recent centuries; and the best guarantee 
for the ultimate success of democracy is this persistent demand for individual opportunity which can scarce be secured under aristocratic forms of government, whether such forms be landed or capitalistic.

The betterment of his material environment is important not alone for man's physical gratification. Such betterment enables men to devote their attention to that which is not bread. The "misery of boots," as one writer aptly describes it, must be overcome before the individual can realize his spiritual desires. ${ }^{1}$ The proposal to fill men's stomachs as a stimulus to their morals is worthy of attention, even though experience shows that great material prosperity is not conducive to the spiritual advancement of individuals or of nations. A degree of prosperity is indispensable, though an excess may prove disastrous. Luxury, if we mean by this the comforts over and above the necessities of life, may be taken as one of the measures of civilization.

Hence, the most obvious application of science to the problems of society lies in this direction. Science has established a control of nature, through which the material welfare of mankind can be permanently secured. In civilized lands, men can, if they will, produce enough for the entire population to eat and to wear. The problem is no longer how to produce the necessities of life, it is how to distribute them. In production, we are far ahead of our power to effect a just distribution. The socialist is largely correct in his contention, that if we would deal fairly in distribution no man would be obliged to work long hours in shop or mine, but could devote a fair measure of time to his spiritual interests, and that under such a system many social problems would disappear. The first claim for science, as having important applications in the problems of society, is, therefore, its stabilization and extension of material factors which are indispensable. This value should not be minimized, since it 'ies at the basis of civilized life, although it is easy to cite ' Wells, H. G., "This Misery of Boots." 
other applications not so immediately allied to things material.

The claim that naterial environment and social conditions arising therefrom largely determine aspiration and accomplishment will be challenged in certain quarters. There are, in general, two methods of procedure, which are held to be efficacious as means to progress. The one is by exhortation and example, the other by making it possible for the good in men to find an outlet. The former is important, but the latter is prerequisite to the social, and hence to the spiritual, advancement of large bodies of men. Without belying the thesis that the more important values of science are spiritual, we may regard material conditions as of the utmost importance, in so far as they place spiritual attainmant within reach. It can be shown that material factors are a most effective stimulus to social progress; and scientific knowledge is the means by which new material factors are brought into being.

Although the individual and not his environment is the primary factor, the ideals, the opinions, and the mental habits of men are so closely related to their conditions of life that improvement of material and social environment is regarded by many able thinkers as the most practical and effective means to progress. It is even maintained that the moral relations of men in any age are largely a product of the cultural level of the population. Great moral leaders arise and exhortation has its uses, but there can be no real progress save as the level of material, and therefore of social, conditions is gradually advanced. If this be acknowledged, attention should be directed to the amelioration of the conditions which "stop down" aspirations that might spring into being. The cultural level is the vulnerable point of attack, if we really want progress. The reason why exhortation is so popular is that it hurts no one, does not produce disturbing consequences, and is inexpensive for those who foot the bills. ${ }^{2}$

${ }^{2}$ This point of view is ably maintained by J. Beattie Crozier in the volume 
The obvious fact, which most of us will admit, is that "all exhortations to duty and morality, and to elevation and expansion of mind, in the face of material and social conditions adverse to the growth of these virtues, are a waste of time and human energy; and are as absurd as to expect a rich and vigorous fruitage from trees or plants in spite of adverse conditions of soil." 3 Unfavorable material and social conditions are a check upon cultural progress and hence upon the aspirations of men. Individual conscience and perseverance are not a myth. But in a world where things make so many of their relationships, that is, their ethical values, through their influence upon the minds of men, it is idle to suppose that high idealism will long flourish in the face of a sordid environment. The talk about men being men in spite of adverse social and material circumstances is well enough, but it is a terribly effective means for the perpetuation of iniquitous conditions. If men's ideals are not literally bred of their surroundings, it is true that their ideals are thus conditioned. The material and social environment, in other words the general cultural level, is a limiting factor in the advance of society along the lines of the elevation and expansion of the individual.

Scientific knowledge of fact has importance in the above connection, because through science alone can men control their material and social surroundings. Invoking a supernatural control of these surroundings may be still practiced, in the case of little-understood phenomena like disease and the weather. But confidence in the effectiveness of such invocations is rapidly disappearing, because mankind is learning that the new way and the sure way lies through the

"Civilization and Progress," in which he strenuously opposes the doctrine that civilization is to be forwarded, rather by exhortations to duty and morality, than by the gradual amelioration of the material and social conditions of mankind. Crozier is thus opposed to Carlyle, whose emphasis upon spiritual values led him to pour contempt upon the whole of material existence.

${ }^{3}$ Crozier, J. B., loc. cit., p. 383. 
knowledge called science. When it is once discovered that any set of phenomena is predictable, and to that extent controllable after the manner of science, men cease to believe in the control of these phenomena by supernatural agencies. Thus it happens that the realm, in which supernatural controls are believed to be effective, is being progressively diminished. The scientific method is likewise important, because through this method alone can men induce the frame of mind necessary for progress and for the control of social institutions.

Concrete examples of the relation between scientific knowledge and the material and social conditions in civilized life need hardly be cited. This practical aspect of science is familiar to all. The man in the street knows that science gets him what he wants in his industrial enterprises, in agriculture, in household convenience, and in all the varied materialities of life. This aspect of science constitutes its justification in the eyes of the world. Moreover, the familiar facts in the recent history of the western nations make it a matter of common knowledge that a host of popular material comforts, which were only for the rich and powerful at an earlier day, are the outcome of a practical knowledge of the natural world, which is the more exact knowledge of applied science.

Social progress depends largely upon, first, the extent to which society has developed the material conditions upon which any advance of the cultural level must depend, and second, upon the extent to which these conditions have been diffused and equalized. The material basis for the finer aspirations must be the birthright of a large majority, before any change can be expected. Within the recent centuries, science has accomplished this extension and democratization of the material environment in western society, by increasing both the volume and the nature of the physical comforts which the majority can enjoy. Science has created the material foundations of western culture. 
Upon these foundations it has been possible to raise a growing edifice of aspiration.

It therefore appears: that scientific knowledge is the means to control of the physical environment; that proper physical environment is prerequisite to a proper social environment among men; and that the level of any society is an immediate function of the material, and hence the social, conditions that exist. In a savage society, living without safe and permanent means of subsistence, the higher forms of relationship between individuals are non-existent. Aspiration cannot exceed the cultural level. In a modern community, where decent material conditions are denied to any large class of the population, and where, as a result, social conditions are at their worst, it is idle to expect a flowering of the nobler aspirations. If these aspirations are thus related to material conditions, which are dependent upon scientific knowledge, the basic importance of science in the solution of social problems must be acknowledged.

\section{FUNCTION OF SCIENCE IN SOCIAL PROGRESS}

But important as its material applications may appear, a deeper social significance lies in the influence of science upon the outlook of the individual mind. The manifold interactions between the members of a modern community are dependent upon science for their successful outcome, although here the relationship is less direct and the complexity of phenomena, which involve men as well as things, is such that the applications of science are less easily recognizable. The influence of science in this connection lies in the fact that scientific thinking produces $a$ state of mind which makes for that expansion and extension of the individual which appears to be the goal of civilized society.

Society suffers, because its members are so largely influenced by their emotions. Mankind will doubtless continue to be guided by the heart rather than the head, but it is 
to be hoped the former may listen more to the latter. That is to say, it is important that we consider probable consequences before adopting new lines of procedure. At the beginning of clear thinking, in all politico-social questions are facts that have been more or less scientifically ascertained. The scientific method is needed at every turn, if complex social situations are to be dealt with in any other fashion than by the blundering methods of the past. The plea is not that the scientist is always a good citizen, but that the scientific method is useful for the citizen; that, as social life becomes more complex, it is necessary to apply the method of science, as a tool wherewith to shape the conclusions which shall guide our social conduct. The need for scientific knowledge and insight is particularly great now that society has become so highly organized. At an earlier day, the problems were simpler and the ignorance of the population was the element that made the situation seem hopeless. To-day, ignorance is still the greatest bar to progress, but it is an ignorance that shows signs of enlightenment and that is frequently maintained on an artificial basis by tradition and propaganda.

The difficulty in taking over the scientific frame of mind, to fields where personal considerations hold sway, is acknowledged. The scientist, who exhibits dispassionate judgment in a restricted field of investigation, is not infrequently as narrow-minded in his social judgments as the individuals in other callings whom the scientist sometimes holds up to scorn. It is difficult to be open-minded and dispassionate where self-interest is involved. But the frame of mind which is avowedly and conscientiously disinterested and progressively inclined is more likely to produce good citizenship than the one which habitually works on closed circuits.

There is one very practical point of difference, in the application of scientific principles within the field of the social as compared with the natural sciences, which has a bearing upon the taking over of the scientific habit of mind. 
It is comparatively easy to make experiments in the natural sciences. Two chemical compounds may be brought together, a group of physical conditions may be arranged, an animal or a plant may be subjected to new conditions; even in medical science, it is not difficult to find an individual whose hopelessness over his own case or whose altruism will lead him to try the new cure or to allow himself to be infected with the virus. It only takes one experimenter and one trial to begin with. If that is a success the experiment may be repeated again and again; and, in the case of experiments upon individual human beings, satisfactory results quickly lead to the willingness of a larger number of individuals to become subjects for experimentation. The result of this in such cases as the use of anæsthetics and of anti-typhoid vaccination, is the very rapid extension of any procedure that gives satisfactory results.

But within the field of social phenomena, the trained observer may feel sure that a social experiment, such as a reform of the currency, is justifiable. Yet to perform the experiment, it is necessary not merely to convince one human being, then another, and another, but to persuade the dominating element of a population to submit to untried conditions. Moreover, the complexity of the situation and the time required are such that the outcome may always be called in question. It is as though a civil engineer could never experiment with the stresses and strains on his bridge until just such a bridge had been built full size; and could not build it until he persuaded a majority of the population to embark upon a venture which might prove disastrous. Yet society from the beginning of civilization has been continually embarking upon such ventures, unconsciously blundering through with them at whatever cost in human life and treasure.

Conscious attempts to solve the problems of society have had no very obvious influence in the past nor do they in the present, because social decisions are made not by 
competent thinking but by blind reactions. The effort of innumerable individuals, each pushing his own way and led by what appeals to his own imagination, constitute the medium in which progress develops. Nevertheless, if rationality amounts to anything in the world of social relationship, we must act on the assumption that intelligent analysis counts in the long run. Now that so many are able to read, even if they read only newspapers, it is possible for human thought to carry farther than ever before.

The thinker is always at a disadvantage as compared with the demagogue, because the latter so readily captures the popular imagination. The discriminating insight into the problems of human life, which may characterize the finer intelligence, is often directly felt by only a small circle of readers and acquaintances. But in the end the progress of society seems to be dominated by the ideas of a few minds; and usually these ideas are relatively simple because they are fundamental. Descartes and Darwin are examples of individuals whose thought has influenced the structure of society. The triumphs of the ancient science were seemingly obliterated by the unscientific attitude of the Roman mind and by the social disasters that overtook the Roman Empire. Yet the concepts of Hellenic genius, through their re-creation and extension in the Renaissance, made the modern world.

Open-minded consideration of ideas involving social readjustments is clearly related to the conscious direction of social progress. Society regards change with such suspicion there is no danger that change will ever occur with undue rapidity, despite the recurrence of revolution. Conservatism is seldom out of the saddle for long at a time, and is, in general, supported by all forms of human activity, with the possible exception of science. Religion, art, government, and even education represent the conservation of what has been already won. Science is the one field of human endeavor, which, from its very nature, looks forward rather than back- 
ward. Religion harks back to revelation; government, as expressed by law, is founded upon precedent, the emotional factor in art arouses primitive psychic states. Science is not only the latest born, it is also the only form of human activity which is continually projecting itself into the future.

Under these circumstances, the scientific frame of mind, with its disregard for precedent, is of evident value in solving social problems. Open-mindedness and fair judgment in such questions are essential to progress. Honesty is needed, and so is sense. The method of science is the method of fair judgment and of the open mind-the state of mind which makes progress a possibility. Moreover, the method of scientific thinking is the competent method in the analysis of complex situations, despite the claims for intuition. One might characterize the kind of thinking that is done by the vast majority of human beings as in one dimension. A small number think in two dimensions, and a very few in three. This last form of thought is about as comprehensible to the individual of the one dimensional mind as is the fourth dimension of the mathematician to the ordinary layman. Blind acceptance of what is, because it has been, is an example of one dimensional thought. Habit and tradition incline us to take things pretty much as we find them. When an individual arises who seriously questions tradition, he is regarded as dangerous.

Now it is against the flooding current of traditional beliefs that science has struggled in the past and must struggle in the future. The unscientific frame of mind does not seem to be born into men so much as it is trained into them by education. The cases of individuals who begin in the old grooves, but by some lucky chance of education or opportunity find themselves and grow into the broader state of mind, are sufficiently numerous that one need not feel discouraged for the race. But it is a serious indictment of our educational system that the schools are much concerned with what has happened and little with what might happen if men would 
use more of their wits. The true ideal of education is a leading out, as the derivation of the term implies, and this is in line with the ideal of science, which is the discovery of new truth.

Science causes social progress by its incessant erosion of the traditional ideas that tend to keep society within the established bounds. Science is thus a dynamic factor. This does not mean that great civilizations are impossible, without organized science in the modern sense, but that society advances only in so far as it is influenced by the spirit characteristic of science. Ancient Egypt possessed a high civilization, founded, as we have seen, upon scientific knowledge in the arts. But the Egyptian and also the Mesopotamian civilizations possessed little beyond the pomp and panoply of social organization, because their culture was not an expression of the progressive spirit expressed in terms of collective organization. Greece, alone among the ancient nations, kindled the undying fire. The scientific factor in western society first arose in Hellas. Some of the far-eastern civilizations of modern times seem to represent a frame of mind, essentially like that of earlier cultures. They are not likely to be shaken from their lethargy so long as the spirit of conservatism prevails. India, for example, is not likely to be profoundly changed by the preaching of any new religious philosophy, for India is surfeited with religious philosophies, but by the development of a willingness to break with tradition. The history of Japan within the last half century shows what can happen when the spirit of change strikes home. ${ }^{4}$

The claim that the progressive attitude of science furnishes a dynamic factor in social progress thus rests upon the fact that the scientific state of mind is the one that readily breaks with tradition. Science is a persistently radical factor in

${ }^{4}$ We do not imply that the immediate outcome in Japan or elsewhere is other than deplorable. But the results that can be attained where there exists the will to break with tradition must be acknowledged. 
society. It works from the bottom, by changing material conditions in such a way that new horizons are opened. It works from the top, by challenging old ideas and traditional schemes of social organization. The conservative function has its value, but the radical function gives us new worlds for old.

\section{THE SCIENTIFIC VERSUS THE LEGALISTIC MIND}

As intimated in the preceding section, two contrasting points of view appear within the social field. It is not that human minds are sharply divided in two different sorts, but that two states of mind, which all men possess in some degree, contend for the mastery. On the one hand is what may be described as the legalistic frame of mind, and on the other the scientific. The use of the term legalistic does not imply that the former attitude is the exclusive possession of one profession, although it is well exemplified by the mental outlook of many lawyers. This word is used, because it is more expressive than such a term as conservative. The radical and forward-looking nature of the scientific mind has been sufficiently explained. The obstacles to its expansion call be illustrated by a comparison with the antithetical spirit of legalism.

What is here designated as legalistic is the spirit which is tied to the past, and which looks for guidance to what has been done, rather than to what might be done in any social situation. This mental state appears: in the lawyer, who believes that constitutions should be the molds for society rather than being molded by society; in the churchman, who believes that men exist to glorify the Church and not the Church to express the idealism of men; in the political Bourbon, who harps upon the democratic ideals of the past without making their obvious applications in the present; in the military man, enmeshed in red-tape and unable to find his way out; and in the industrial magnate, who, having 
accumulated wealth in ignorance of the world of ideas and of the essential facts in human progress, poses as an expert in the problems of society and opposes any suggestion of change in the social situation. On its emotional side, this type of mind is often strongly religious in a formal way. It possesses moral convictions which are incapable of progressive development; while a general inclination toward mysticism and conventionality, together with a willingness to accept irrational explanations, indicate that it is a survival and might properly be described as archaic, when compared with the outlook of the modern world. The intimate relation existing between the sacerdotal and the militaristic spirit is but one example of a linkage that connects together a whole series of mental states which are deep-seated, and which are, in general, opposed to the rationalism of scientific thought.

The behavior of the legalistic mind within the legal profession presents striking illustrations. Research in anthropology and archæology has shown the probable course by which law and justice originated from their foundation upon the minimum of mutual confidence, which was necessary, before any associations beyond the family could be formed; and upon the attempts to punish digression from the unwritten laws of the group. Some measure of loyalty, selfrestraint, and honesty had to be enforced from the first. Law and the administration of justice arose from this natural source and not from supernatural revelations. The later evolution of the law and its ideals in the European world are familiar to the student of history. The law has exercised its larger functions, only in so far as it has adjusted itself to the new demands of a changing social order. It is necessary to have regard for precedent in order to conserve those practices of the past which are applicable to the present. But the real problem for the law is what is here and now, not what was at an earlier period. The lawyer tends, unconsciously, to feel that his law came down from heaven, and that what has 
been is more sacred than what might be. This is not unnatural, because it is an important function of the law to administer the kind of justice, which has been arrived at through the experience of the past; and because the results of experimentation are uncertain. To the conservative mind, there is a majesty to tradition and precedent, because they represent what so many individuals have accepted in the past, it matters not how blindly.

The stickling for the phraseology of an indictment, while the essential facts of the case are disregarded, is a familiar illustration in the legal procedure of our own land. The English law, from which ours took origin, has largely eliminated this insistence on the letter, which arose at a time when merciful judges attempted by this subterfuge to save unfortunate individuals from the action of harsh laws. Insistence upon the letter has survived in America, because we are a conservative nation, and because the members of an over crowded profession must earn livings. The lawyer is wonderfully able to keep in mind the essential point, in true scientific fashion, when he is after the facts of evidence. As a judge upon the bench, he shows that he can sift out facts according to the method of science. His point of view is wholly different when it comes to the law as a function of society. To the mind of the scientist, the law should drive through with an eye to the main issue, which is the administration of justice in a changing world. Neither justice nor morality have absolute values which men have as yet discovered. The belief that they have such values is a survival from the concept of a static world.

The violent resistance of the legal mind to innovations, which threaten social readjustment, is a result of the selfinterest involved where law and business hunt together, and of the precedent-following mind. For example, the suggestion that in cases where an employer surrounds his employees with riot-producing conditions, he is to be classed as one of the responsible parties is a new idea and as such 
it falls upon stony ground when cast into the legal mind. But forget the law and regard the ease with an open mind! What is it we are after any way? Is it the profit of the individual employer or is it the expansion of the individual, in so far as his expansion does not stifle the opportunities of other individuals like himself? Proposed restriction of the employment of industrial spies is a further example of a legal innovation that will no doubt be opposed by the mental attitude of legalism as well as by the paid activities of the legal henchmen of the industrial world. ${ }^{5}$

Take the broad problem of vested rights: The scientist holds no brief for confiscation. But what appalls him is to see conservatism, so blind as not to realize that confiscation is sure to come when a social situation becomes intolerable, as during the French Revolution and more recently in Russia. There is a type of mind which never realizes that the reason why men protect property is that protection of property is necessary for the safety of the individual. The individual and his life is the real issue. In the long run, vested property rights can survive only as they square with the right of the individual to life and opportunity. There are lawyers who have the broader view of law. But there are too many of them who think society is static, and that ideas can be restrained by machine guns and policemen's clubs, backed up by legal precedents.

The influence of industrialism in civilization presents a curious contradiction, in this conflict between the legalistic and the scientific mind. Modern industry has been responsible, more than any material factor, for the spread of the matter-of-fact and rationalistic point of view. The idea of scientific causation has established itself in the popular imagination, largely through the fact that men have every-

${ }^{5}$ The development of the spy-system in industry has been investigated under the auspices of the Cabot Fund for Industrial Research. See pamphlet entitled: "The Labor Spy," which is a reprint of articles published in The New Republic by Sidney Howard. 
where become familiar with the laws under which machines are set in operation. The idea of man as a controller and director of natural forces and not as a worker of miracles, and of nature as something which acts according to discoverable laws has been the work of the thinkers. Its wide acceptance has been an incident of modern industrial development. This situation was mentioned in our account of the practical applications of science during the closing decades of the eighteenth century. Moreover, on its commercial side, the industrial character is distinctly matterof-fact and scientific, caring mainly for results. The growth of such a frame of mind exercises an important influence upon the intellectual horizon.

But with the rise of great industrial organizations during recent years, the inertia, with which science has always to contend, appears in a new guise. The stronger forces of conservatism to-day appear, intrenched within the industrial domain. The more extensively the older dominance of Church and Government is replaced by the all-powerful domination of bourgeois Industry, the more Industry becomes an obstacle to the freedom of science. In the past, the scientific spirit has contended with ancient dogma in the form of theology. To-day, it is being confronted with the Great God Business, which, although it fosters the material extensions of science, is, on the other hand opposing the extension of the scientific frame of mind in the solution of social problems. Just as industrialism tends to eliminate war, by establishing a pax commercii, while the rivalries which it engender's constitute the underlying cause for modern wars, so industrialism, while fostering the spread of a scientific state of mind among the toilers, shifts the authority in society from those who dominate Church and State to those who dominate Industry. It thus enthrones Industry as the strongest defender of the status quo against which the scientific spirit now contends. The hopeful aspects of the situation are the growth of the scientific 
state of mind among the masses and the growing demand from the engineer and expert technician for a position of equal importance with that accorded to the capitalist. The matter-of-fact demands of science are having their influence in the central organization as well as in the lower levels of industry.

Psychology may some day know enough regarding the reactions which indicate a permanent closure of mental circuits so that many an elderly gentleman, who would now occupy a place of authority in matters of social welfare, will be relegated to a subordinate position, in favor of the man of open mind, who has enough elasticity remaining in his arteries and elsewhere to make him fit to assume authority in matters that affect the lives and happiness of large numbers of men. In war, if war lasts that long, it may also be possible to select, at the outset, generals whose wits have not undergone ossification; and in industry to curtail the influence of those who are hopelessly unable to meet new social situations.

The fact that men easily establish a reputation for sanity and sound judgment when they never depart from established points of view, and the fact that men tend always to regard as sane those who agree with them are the two strong buttresses which support the wall of conservatism against the pressure of new ideas. It is considered safe to follow the precedent. But is the following of precedent the mark of insight so much as of the lack of this quality? The sheep-like tendency to go with the herd is a very human trait, but is it what we should honor? Will it get us anywhere in the future?

Like industry, modern journalism acts as an encouragement and also as an impediment to the scientific attitude of mind. A situation has developed, which we are just beginning to recognize, and which marks the appearance of propaganda as a distinct factor in social progress. What has been essentially propaganda has always been used in society, 
when certain individuals or groups have sought to mold the ideas of a population by indirect methods. The modern and secular form of propaganda has developed in intimate relation to the advertising of modern business. The characterization of advertising, "as persuading people to buy things they do not need and would not want if they were not overpersuaded," may be resented, but it possesses a measure of truth. What we designate as propaganda is the attempt to influence public opinion by subtle and indirect means. Where the attempt is made by direct appeal and frank acknowledgment of purpose, the term advertising is to be preferred. Propaganda and advertising are, however, so inextricably connected that distinctions are arbitrary. The case of corporations that spend large sums in advertising, which, although descriptive of the articles for sale, is primarily designed to build up a favorable opinion and thus enable the corporation to combat governmental action, illustrates the relationship. The abuse of news colums for this purpose is familiar to all.

With the extension of literacy, the printed rather than the spoken word became the medium of mental exchange; and the newspaper has now become the most effective controller and director of ideas, which civilization has ever known. Not even the Church at an earlier day possessed so effective a means of molding the thoughts of men. The newspapers are, in general, organs of conservatism, because they are so closely allied to great commercial interests. The dangers in such a situation are evident. Now that popular opinion has become so important a factor in social progress, this opinion should be correctly informed. The ideas which the press constantly reiterates become dominant. The social dangers, inherent in the use of propaganda to perpetuate the archaic frame of mind, can only be dealt with by the methods of scientific analysis, backed by determination to get at the bottom of particular cases despite the mass of selfish motive that obscures the issue. The general prob- 
lem of how to secure a measure of social honesty in a world of knaves is here illustrated. There can be no progress toward its solution without recourse to the facts and the method of science and without subordination of the legalistic to the scientific frame of mind.

Further examples of the conflict between this formal, conservative, sacerdotal, legalistic, and, in general, archaic attitude and the scientific spirit might be cited. The illustrations given are sufficient to show the nature of the struggle and the fields in which it is waged. We do not claim that scientists as a group have a monopoly of the scientific frame of mind, but that the nature of science is such that the forward-looking attitude tends to be emphasized more than any other. Science must be willing to stand the gaff, whenever it can be convicted of a lack of open-mindedness and a backward-looking spirit. Men naturally prefer that to which their individual experience has made them accustomed, both in ideas and in material surroundings. Conservatism has this great law of human thinking always at its back. But the frame of mind that challenges tradition is not impotent. Had it been so, a certain type among the higher apes would never have broken with the traditions of animal mentality, as happened at a remote period of human ancestry.

\section{INFLUENCE OF SCIENCE UPON GOVERNMENT}

The influence of science upon governmental organization may now be considered. There are, in the last analysis, but two forms of government-aristocracy and democracy. Aside from maintaining order and administering justice, government exists to promote the general good. To this all will agree. But what constitutes the general good and how it may best be promoted are questions regarding which there is no such agreement. Self-interest and prejudice, together with divergent points of view make unanimity of opinion seem hopeless. Aristocracy and democracy are 
both so strongly defended upon the ground that each produces the greatest good, one wonders whether the problem is not so complicated that the bearing of science upon the form of government cannot be ascertained. Nevertheless, certain clues are apparent. The fact that the western ideal of democracy has developed side by side with the scientific frame of mind, and that aristocracy is commonly associated with the older forms of thought is not without meaning.

Science, with its emphasis upon matter-of-fact judgments and its disregard for precedent, has been a factor at every step in the advance from the despotic aristocracies of the ancient world to the modern democratic states. In ancient times, government was intimately associated with religious leadership, the ruler being either a priest or an individual regarded as consecrated by divine authority. Belief in the divine right of kings was the last disturbing survival of this ancient union of Church and State. Secularization of government has gradually broken down the connection between ruler and priest. Rationality has applied itself in political life; and since political life accomplishes for the many what philosophy does for the few, the spread of the rationalistic attitude has been encouraged by the political activities of larger numbers of men. The judicial spirit, which is an outcome of the secularization of government, is the rational, scientific spirit appearing within the political field. The give-and-take of political activity fosters a spirit of independence and the spirit of independence leads to new forms of thought along other lines.

We regard democracy as a sound concept of government, because of its effects upon the individual. One must believe that the influence of a dominant and privileged group, particularly one that rules by hereditary right, is not conducive to the extension and elevation of the individual mind for which mankind seens to be striving. The fact that the forms of democratic government, through which the elevation of the individual has been attempted, have often proved 
unsuccessful does not mean that the ideal of democracy is unsound.

In taking this position with reference to democracy, we are not insensible to the claims of aristocracy. The inequality of men is a biological fact, but it is also a fact that men resemble one another in their more essential particulars of mind as well as body, hence the genus Homo. It appears from biological studies that intellectual ability is widely distributed, and chance Mendelian combinations may at any time give rise to genius in peasant hut or city slum. The indictment of aristocracy is that it degrades the masses; while among the few that are elevated, a large proportion are maintained in their position by hereditary advantage and not by personal worth. The relation of servant to master is beautiful in a way, if the master be a just one and the servant faithful. But the finer human qualities are not developed by those who are submissively obedient, nor by those who assume the obedience of others to be their right. It is when men contend with men in a fair field with no favors that the virile qualities of the human spirit make their appearance. Those who cry that men should think on duties not on rights forget that duty means submission, and that while submission may be necessary at times it should be regarded as a means to an end not an end in itself.

An established aristocracy must always be founded upon certain unfair advantages. These advantages may be the visible splendor of vast estates and palaces or they may be the prestige which makes great splendor unnecessary to command the respect of inferiors. The industrial aristocracy of the modern community is a case where the visible foundation is in evidence, while the German Junker, whose income from his land was far from lucrative, was a case where prestige was substituted for more impressive possessions. From now on, it would seem impossible for any form of society to endure which does not tend toward equal opportunity among the people as a whole. True, the attempts at de- 
mocracy among the western nations have had a pitiful outcome to date. It appears that we have but replaced an aristocracy of birth, originating in military prowess, by one of wealth, originating in commercial greed. The new masters have no tradition of a God-given obligation, and they possess no creed but that of power. The outcome can only be an entrenched aristocracy, worse if anything than the older forms, unless we can check the concentration of wealth and its transfer, through inheritance, to those who have not done the concentrating, to say nothing of the producing.

This new aristocracy casts its shadow directly athwart the progress of society as a whole, since material and social conditions must be in a measure equalized, before there can be an approach to the equality of opportunity which alone can satisfy the demands of an advancing civilization. Science made modern industrialism a possibility. Industrialism has been the most important factor in completing the overthrow of feudal aristocracy. And now industrialism creates new aristocratic traditions. The solution of the situation again lies with science, this time with science applied directly to the problems of society. It has been said that the cure for the evils of democracy is more democracy. This does not appear to be true, if by more democracy we mean more voting on more detailed issues, as in the practice of the initiative and referendum. But if we mean by more democracy a nearer approach to the ideal which proclaims equal opportunity to all and special privilege to none, the cure is to be recommended. Equality of opportunity has become imaginable, because science presents the means to this end, however difficult the road. Society seems to have reached an impasse, unless a greater measure of this equality can be realized through more effective social organization. Science points the way to such organization.

A better balance of porver between the different groups in society would seem one of the means of securing greater equality of opportunity. An equality of mights tends to- 
ward an equality of rights. Hence, democratization of industrial enterprise appears to be one of the most important single steps now before us. Such democratization can be accomplished only by the application of scientific knowledge to particular problems of social organization, and by the further extension of the scientific frame of mind as it affects our concept of the rights of the individual. The idea of a common humanity and of the dignity of individual human life was promulgated on its ethical side by the Founder of Christianity. On the intellectual side, this recognition of the dignity of man seems first to have become a fact, rather than a notion, during the Renaissance in Italy. At that time, distinctions of birth lost their former importance, because "men were here first thoroughly and profoundly understood. This one single result of the Renaissance is enough to fill us with everlasting thankfulness. The logical notion of humanity was old enough-but here the notion became a fact." ${ }_{6}$ The earlier ideas of merit or demerit, as inherent in particular social groups, first began to disappear, under the influence of the rationalistic doctrine of personal merit and demerit. This point of view has since had an important influence upon the spread of the democratic principle of equal opportunity.

It is also possible that some relatively simple material discovery may have far-reaching effects as an equalizer of opportunity. Historians commonly believe that the introduction of gunpowder into Europe worked in this manner, by making the footman the equal of the knight on horseback, and by rendering the feudal castle no longer secure against attack. Latterly, the development of elaborate engines of warfare have again given stability to entrenched power, battleships and artillery to powerful states, machine guns and poisonous gas to the hands that can use them against rebellious subjects. But it is conceivable that, with some new twist of material discovery, all these may pass

${ }^{6}$ Burckhardt, J., "The Civilization of the Renaissance in Italy," p. 354. 
away. Nations and social groups within nations which now find themselves physically impotent may come into new powers.

Individual organisms, contending for the opportunity to live, is the scheme of things throughout the world of living nature. Individuality, with the minimum of restraint, appears to be the working basis of the animal and plant world. The democratic ideal is in line with the individuation that pervades organic nature and that finds its highest expression in the extension and expansion of the individual which appears to be the goal of civilization. Individualism is restrained among animals and plants by the presence of many individuals together. Where new territory is being occupied, by men or animals, individualism may go mad, as it has done in America during the era of exploitation now drawing to a close. The outcome of such an orgy must be either a new-formed aristocracy or the bringing to heel of individualism in order that the many may again have opportunity.

In view of the historical movement toward democracy and the present status of democratic government, we believe that the ideals of science are parallel with the ideals of democracy; that the growth of science has fostered the growth of democracy; and that democracy offers the type of governmental organization which is, of necessity, committed to the development of science in the future. In the recent past the influence of science and of the scientist in government has been indirect. Law and the legal profession have been dominant, because government has consisted largely of the administration of established procedures. The dominance of the lawyer in government is natural and almost inevitable. But when, as in our own country, the situation becomes, what has been jocosely termed, "a government of the lawyers, by the lawyers, and for the lawyers," such government is not conducive to an intelligent handling of many important questions. The precedent-following mind 
may be looked to for guidance so far as government is the administration of what has been established. But in so far as government consists of problem-solving, it might better be conducted by those whose business is the solution of problems. The successful conduct of government in the modern world, although it consists largely of the performance of established operations, also demands the ability to grapple with new situations and to solve problems which already exist. The failure to perform this second function is due to the dominance in government of a mental attitude which is interested in operating the machinery as it has been operated, and not in the invention of new machinery or of new methods of operating the old.

Democracy can justify itself only by more effective accomplishment than in the past. Science appears to have fostered the democratic ideal in the past. At the present day, science, rather than legalism, offers the means of triumph to democracy in the future. A time must come when the scientist, and by scientist we mean the engineer, the chemist, the sociologist, the economist, and the like, will be accorded his rightful place in the affairs of state.

In the foregoing discussion of science in relation to the problems of society, the general applications of the scientific point of view have been emphasized, rather than specific applications in concrete problems. As in the ensuing discussion of values, it is assumed that the practical importance of science is familiar to all. We have emphasized the influence of science upon the human mind. Its concrete applications in social questions, like public health, eugenics, industrial problems, divorce, the problems of sex, of population, of public taste, and the like might have been considered at length. But we have chosen what we regard as the underlying significance of science within the field of human relationships.

The idea at the bottom of western society seems to be that man does not need to sit passively content with his lot, but 
that he can, within limits, control his environment. Control is secured through science. The immediate outcome of this underlying concept is frequently disastrous to much in the older cultures that might well be preserved. It appears that no other type of organization can stand against the matterof-fact. Whether this practice can succeed remains to be seen; but for the present it goes steadily forward. Science acts as a dynamic factor in progress, on the one hand by ameliorating the material conditions of human life, and on the other, by continually destroying dogmas that restrain the human spirit. Scientific knowledge induces not only new worlds of a material sort, it also constructs new worlds of social relationship as outgrowths of its material creations. In addition, it opposes the formal and legalistic point of view, and aligns itself with democracy. 


\section{CHAPTER XII}

\section{THE HIGHER VALUES OF SCIENCE ${ }^{1}$}

THE material values of science are widely acclaimed. Its higher values are commonly ignored. For the man of the street, science represents only control of his physical environment. As a matter of fact, the changes induced by science within this environment are insignificant, when compared with those wrought within the human mind. To designate these higher values of science, the term spiritual may be used, over against the term material, without further implications and without attempt at exact definition. If we speak of man's spiritual yearnings in contrast to his material needs, we may not have a clear concept of what the former term signifies; but we acknowledge, by the frequent drawing of such a contrast, the existence of that which is the opposite of material. That which constitutes the spirit of the man, while too elusive for definition is no less a reality. ${ }^{2}$ Science emancipates the spirit of man by freeing it from ignorance and superstition. The freedom thus acquired enables him to make proper use of his material surroundings. It is time for more emphasis to be laid on this value of science. On the material side, science has won and its victory has been acknowledged and acclaimed. On the

${ }^{1}$ A considerable portion of the matter contained in this chapter appeared in Science, June 14, 1918, as part of the Symposium conducted by the American Society of Zoölogists, Minneapolis, Dec. 29, 1917.

2 The term spiritual possesses an unfortunate connotation for the scientific mind. But there is no reason why a word for which a satisfactory synonym can hardly be found should be monopolized by a particular field of thought. If scientific men speak of their scientific spirit, they may with equal propriety refer to the spirit of man and to the spiritual values of scientific knowledge, without implying either belief in ghosts or tacit acceptance of certain concepts of orthodoxy. 
spiritual side, the fight is on; but its importance is not yet, comprehended. Lest science fail in its larger mission, the significance of the higher advance should be made known.

Science is obliged to exploit its material triumphs in order to gain support in its combat with the idols of the past. The practical man cares little for the thoughts of scientist or philosopher unless they can be turned to economic account. He nevertheless acquires the scientific point of view by insensible stages, because he habitually employs both the method and the knowledge of science in his everyday life. Science is the great transformer of opinion at the present time. And this transformation is accomplished primarily through the material efficiency of scientific knowledge. Just as religion was more effective spiritually, when it was believed that supplication brought desired material blessings, so science is effective at the present day. But the material benefits which science has conferred upon mankind do not constitute the highest scientific values.

\section{SCIENCE AND IMAGINATION}

It is often said that nothing remains for imagination, now that science has destroyed the mystery of the universe. This statement has no basis in fact, and arises from a misunderstanding of what science has accomplished. Instead of restricting imagination, science has so enlarged the mental horizon that imagination may take a bolder flight. To primitive man and to the savage who survived in this state until recent times, nature appeared a thing of caprice rather than of ordered sequence. The world was one of spirits, good and evil, who had always to be considered and with whom man must make his peace. The day as well as the night was peopled with beings who ruled in the absence of any definite sequence of events, and safety could be found only by submission or propitiation. Under these conditions imagination had full play. But who in the present genera- 
tion would choose this kind of imagination? Possibly a few modern mystics and people of irrational and superstitious type of mind.

When men first observed the changeless motion of the stars "without haste, without rest," and gained an inkling that the same orderly sequence might apply to all natural phenomena, the opportunity for imagination was not lost. It was placed on a higher plane. The inhabitants of Europe, whose forefathers once imagined the Islands of the Blest to lie beyond the Atlantic and the Inferno of lost souls to be within the bowels of the earth, have undoubtedly relinquished many fields in which the imagination of medieval man found exercise. But what a vista has been opened! Consider the sweep through time and space of the concept of evolution: The measureless past even of our own planet, the cooling of the gaseous and later molten mass, the differentiation of the land, the seas, and the atmosphere, the appearance of the earliest life, and its progress through time, the age of invertebrates, the ages of fishes, amphibia, reptiles, and mammals, the emergence at length of the ape who walked like a man, and the struggling ascent of his descendants during the glacial epoch. The account of creation in the book of Genesis, when compared with the tale outlined by modern science, is like some nursery story, cherished as part of a departed childhood and wonderful in its proper setting, but not to be classed with the great symphony made known by science, although having its place in legendary literature. ${ }^{3}$

The clouds are no less wonderful because we know something of their relation to the weather. One can watch the sunset, entranced by its colors and imagining islands in a flaming sea or castles in the air. The ocean still "goes nakedly between the weed-hung shelves." 4 Or let us think

${ }^{3}$ A vivid portrayal of these steps in evolution is given at some length in the opening chapters of the "Outline of History," by H. G. Wells. This author has made an eloquent plea for a new "Bible of Civilization," in his volume "The Salvaging of Civilization."

${ }^{4}$ Leslie Stephen has well answered the yearning sometimes expressed for a 
of man as the victor over nature, notwithstanding those laws which are inexorable for other living things. No other species is known to have spread itself so widely over the earth and to have so changed its environment to suit its needs. Herein lies the difference between man and the rest of the animal world. Wherever else an animal has been subjected to a new environment, the result has been death or the evolution of a new type suited to meet the changed conditions. But man has taken himself and his domesticated plants and animals into surroundings to which neither he nor they are naturally adapted; and, instead of paying the penalty inevitable in a state of nature, they have survived, and flourished. Where nature would say "Die!" man has said, "I will live!" And he has succeeded, because he has

return to the imaginings of an earlier day in the following passage: "Wordsworth expresses the familiar sentiment when he wishes that he could be ' $a$ pagan suckled in some creed outworn.' The sight of Proteus and Triton might restore to the world the long-vanished charm. Now, as far as science is concerned, we are tempted to say that Wordsworth is simply wrong. The Greek mythology gave an inaccurate representation of the facts. The more accurately we know them the better for us. A slight acquaintance with the law of storms is far more useful to the sailor than any guess about a mysterious being, capriciously raising the waves, and capable, perhaps, of being propitiated by charms. From the purely utilitarian point of view, we are the better off the closer the correspondence between our beliefs and the external realities. But, further, we are tempted to say the same even in a poetical sense. Why should Wordsworth regret Proteus and Triton? Because the Greek inferred from the sea the existence of beings the contemplation of whose power and beauty was a source of delight to him? But, in the first place, the facts are to Wordsworth what they were to the Greek. If the Greek thought the sea lovely in colour or form, the colour and the form remain. The imaginary being in whom the phenomena were embodied could only be known through the phenomena. The beauty is beautiful still, though 'we no longer infer an imaginary cause. Nothing is lost but a dream, and a dream, which, by its nature, could only reflect the reality. Why not love the sea instead of loving Proteus, who is but the sea personified? And, secondly, we must add that the dream reflects the painful as well as the pleasurable emotions. When the superstition was a living reality, instead of a poetical plaything, we may be sure that it expressed horror as well as delight. The sailor, imagining a treacherous deity lurking beneath the waves, saw new cause for dread, and would often have been glad enough to learn that Proteus was a figment." "English Thought in the Eighteenth Century," p. 14, 2nd Edn. 
forced from his environment the readjustments necessary for his well-being. Not always is this possible. The path is not one of ease, but it is being steadily pursued. In the essay entitled "Nature's Insurgent Son," a noted British scientist ${ }^{5}$ compares man to an insurgent gone so far in his rebellion that there is no return, for whom capitulation can mean only death. The rebel against natural forces must continue on his course until the end is won, if he would find safety. Man cannot now return to the dominion of nature, he must see the battle through, and succeed by mastering his environment and so controlling his destiny. Hence knowledge of how to secure this mastery is more vital to him than aught else.

Again, take the poetry of modern invention. For it is there in plenty when you know how to find it, as Kipling has done time and again, but nowhere better than in his verses on "The Deep-sea Cables."

The wrecks dissolve above us; their dust drops down from afarDown to the dark, to the utter dark, where the blind white seasnakes are.

There is no sound, no echo of sound, in the deserts of the deep, Or the great gray level plains of ooze where the shell-burred cables creep.

Here in the womb of the world-here on the tie-ribs of earth Words, and the words of men, flicker and flutter and beatWarning, sorrow and gain, salutation and mirth-

For a Power troubles the Still that has neither voice nor feet.

They have wakened the timeless Things; they have killed their father Time;

Joining hands in the gloom, a league from the last of the sun. Hush! Men talk to-day o'er the waste of the ultimate slime, And a new Word runs between: whispering, "Let us be one!"

There is a great fund for imagination in the wireless ${ }^{5}$ Lankester, E. Ray, "The Kingdom of Man." 
message. "Warning, sorrow and gain, salutation and mirth" pass over our heads on the wings of the air, and the telling of their passage illustrates the presence of natural phenomena concerning which man knoweth naught, but which are not unknowable. Have we not gained far more than we have lost by such advances of science? Imagination need not go unfed, when out of the fog, the night and the distance, as though from another world, comes that which signals Save our Ship, to listening ears a thousand miles away on sea and shore.

\section{THE ESTHETIC QUALITY IN SCIENTIFIC THINKING}

Esthetic appreciation may seem at first thought to have no place in the field of science. Yet if we analyze the case, our esthetic responses become, when stripped of what is non-essential, intellectual rather than sensuous pleasures. The "good, the beautiful, and the true," as we see them, are largely that to which we are accustomed, whether it be a social institution, a style in dress, or a scientific theory. Moreover, their cost, as one critic shows, ${ }^{6}$ is a factor whose importance is commonly underrated. But may we not hold to the faith that the beautiful and the ugly represent realities over and above that to which one is accustomed and based upon some measure of thoughtful analysis? The difficulty is in regard to the standard or plane of judgment. Within the purely intellectual realm, however, we are on safer ground. For example, the satisfaction one experiences in the demonstrated theorem or in the chain of evidence when the last link is forged, has its clearly esthetic quality. There is the same feeling of completeness as in beholding the creation of artist or sculptor from which nothing could be taken away or nothing added without marring its perfection. Let it be admitted that we appreciate such things merely because our minds run in certain channels. The fact remains that our "Veblen, T., "The Theory of the Leisure Class." 
minds so function, and that as long as human minds continue to be what they are we may expect them to follow similar courses. Stories are told of great minds completing their scientific discoveries in a state bordering on religious exaltation. The tale of Isaac Newton's emotional excitement, when he saw himself approaching the verification of his great hypothesis, is a classic example. The story is that being overcome by his emotions he asked a friend to complete his calculations. The result was that, "in a state of excitement which is said to have been so great that he could hardly see his figures, he proved that the fall of a stone to the earth and the majestic sweep of the moon in her orbit may be ascribed to one and the same cause." 7

But ordinary men may feel the thrill of discovery even when the work is not their own. In intellectual manhood one recalls how certain theories in science or ideas in literature gripped the mind when they were first apprehended. It mattered not that they had been produced by others. They opened new horizons. Nascent generalizations, such as the Mosquito-Malaria theory as first proposed or the explanation of Mendelian heredity and of sex-determination in terms of chromosomes, give the joy of discovery even to those who have no part in their investigation. In spite of uncertainties and the necessity for further study, one often feels that he is gazing at a picture, near completion and so wonderfully ordered as to call forth esthetic fervor. To many of us, therefore, scientific thinking and the contemplation of the theories of science, present an esthetic appeal of the first order.

Moreover, it is a fact that some of the highest forms of esthetic appreciation are of comparatively recent origin, having been developed within the period dominated by modern science. Of all the ancient peoples, the Greeks attained the greatest development of the esthetic sense; and all things considered, no modern race has ever equalled their

"Whetham, W. C. D., and C. D., "Science and the Human Mind," p. 129. 
attainment. But in some respects esthetic appreciation was undeveloped even among the Greeks. The beauties of the landscape seem to have been largely ignored, at least such beauty is not commonly referred to in the Greek literature that has been preserved. The influence of Christian theology partly obliterated what remained of the classical artistic sense after the fall of the Roman Empire. Despite the Gothic cathedrals, which typify medieval exaltation and aspiration, the modern esthetic spirit has been a new birth coincident with the rise of the rationalistic spirit. Dante's appreciation of nature was a new note and is distinctly modern. Petrarch's descriptions of natural scenes, his mountain climbing, and the beginning of modern landscape painting in the work of the Italian and Flemish artists of the fifteenth and sixteenth centuries, are examples of the lifting of the veil thrown over nature during the Middle Ages. These esthetic developments have occurred in a period dominated by science. ${ }^{8}$

It is, therefore, hard to believe that there exists in science anything hostile to the esthetic frame of mind, when we realize that this re-creation of the esthetic sense and its subsequent development have been accomplished in part by individuals, who, from Petrarch onward, have been imbued with the spirit of the modern scientific mind. The Greek use of art to inculcate right thinking meets the unqualified approval of the modern scientific student of the methods of education. And it is recognized by every broad-minded follower of science that outside the sphere of scientific investigation there exists another approach by which men may draw near to nature, namely, through the appreciation of nature's beauty. The scientist, therefore, finds esthetic delight in his intellectual endeavor, and he does not find his senses dulled to the beauties of nature, save as the intensive study of particular phenomena inevitably leads to a certain

${ }^{8}$ Burckhardt, J., "The Civilization of the Renaissance in Italy," Pt. IV, Chap. III, "The Discovery of Natural Beauty." 
disregard of what is seen by the artist. The artistry of the microscopic organism or of the spiral nebula is not unperceived by the man of science, but he is interested also in other aspects of these natural objects. Not being an artist, the scientist does not perhaps fully recognize all the form and color that is evident to the artistic eye. But neither does the artist recognize all the special details which are appreciable to the scientist.

\section{SCIENCE AND FAIR JUDGMENT}

A further aspect of science, having spiritual value, is the ideal of fair-mindedness inherent in the scientific method of reasoning. If the essential element of scientific thinking is reasoning in a way to reduce the personal equation to a minimum, science may perform an important service by helping us to impersonal judgments in other lines. The scientific attitude of mind aids in dispassionate consideration of subject-matter that is frequently dominated by prejudice.

The concept of evolution, both organic and inorganic, may be cited in illustration. If this be presented as an interpretation of the facts of nature, to be accepted or rejected on the same basis as one would the earth's sphericity or the Copernican theory of the solar system, it is easy to show that the cases are parallel, when viewed impersonally and as scientific problems. Once involved in the subject, one passes insensibly to the problems of society, which are at bottom evolutionary problems. Poverty and crime, eugenics and euthenics, the organization of the state, and the rights of the individual are debatable in no such simple terms as comparative anatomy and embryology, palæontology or ecology; and because of this they are subjects for prejudiced controversy rather than open-minded discussion. Let us take the case of poverty as an example. One possessed of the scientific temperament cannot possibly regard this as a question to be decided wholly in terms of 
the convenience and profit of the landlord or the employer of labor. It is a question involving the welfare of the individual and of society, and all the facts that seem to have a bearing need to be carefully considered, before an effective policy can be discovered leading to the elimination of this festering sore from our social life. The biologist may be influenced by his preconceptions of heredity and environment, the humanitarian by his quickened sympathies; but in so far as either shuts his eyes to the evidence and fails to consider all the factors involved, he is false to the scientific spirit, which must be the final arbiter in the just decisions of conscience. We contend, therefore, that the scientific method furnishes the only talisman that can be used effectively in solving the complex problems of social life; since it enables us to grapple with these problems in dispassionate fashion, and since it makes for fair judgment and the elimination of prejudice.

This elimination of what influences the you and the me, in favor of what can be agreed upon as a fair interpretation by us all, is no easy matter. Scientific men do not always live up to their ideal of dispassionate thinking within their own domain, nor do they always carry over this ideal to daily life. But the impersonal manner of thought is a priceless possession of the human race. If men strive to apply it in the problems of human relationships, the effort is worth while, however short it falls of the ideal. We need more facts of science for our material progress; but more than this we need the unprejudiced judgments of science for the penetration of sham and for the elimination of personal interest in dealing with our fellow men.

\section{THE SCIENTIFIC SPIRIT AND THE OPEN MIND}

The ideal of fair judgment necessitates living in a state of suspended judgment with reference to many questions. Those who acquire the scientific frame of mind find that it 
enables one to live, on the edge of difference, instead of in the emotional attitude of onesidedness. For one who assumes the latter position, the important questions of life are settled, it matters not in how dogmatic a fashion. It is, of course, sometimes better to settle a question, even wrongly, than to endure the paralyzing effects of an uncertainty that inhibits action, where action of some sort should be taken without delay. But it is a very human failing to form judgments upon, and to settle out of hand, matters which call for investigation before any intelligent action can be taken. The ability to suspend judgment is a necessary corollary of the fair judgment, which all men profess, but which so few attain that one wonders how it can ever be attained by men of action. Men so yearn for the settlement of important problems that settlement is commonly made, irrespective of the facts which might be ascertained. The mind tends to emotional rather than intellectual decisions, and to a closing of the circuit once a decision has been reached. Established convictions prejudice the thought of every individual in ways of which he is quite unconscious. An open mind is the ideal to which most men aspire, but which they never fully attain.

The open-mindedness that comes with the ability to suspend judgment, where judgment cannot be based upon adequate data, is an ideal of science. The very nature of scientific truth makes it clear that the open mind must be maintained, even in matters which the scientist believes to have been firmly established. Science has value, because its methods of thought dignify both the suspension of judgment and the willingness to revise judgment that condition the open mind.

The intellectual advancement of individuals and thus of nations is obviously dependent upon the acceptance of new ideas. The opposition to any significant change in social customs, in legal enactments, or in religious beliefs is but an illustration of the fact that the individual resents any 
alteration in that to which he is accustomed. The reason why youth accepts innovations, which shock old age, is that the mind of youth has not become so wedded to established practices. If the innovation survives, and becomes a part of the social order, the generation which has accepted it may later resist a further change. One of the tragedies of life is the fact that so many minds close at the threshold of what might have become a great adventure. We hear a great deal about the individuals who choose the wrong moral direction, and the facts are serious enough; but we hear little about those who choose the closed in place of the open frame of mind, whose intellectual development ceases before they are grown to man's estate and who go through life with a mental attitude that is immune to new ideas. Whatever the shortcomings of the individual scientist, the ideal of science is one of intellectual development, of a state of mind that is always open to conviction when presented with new evidence. This mental habit is not easily maintained because of the human tendencies aforementioned. It is, however, indispensable to intellectual and also to moral progress.

In professional life, men not infrequently fail because they lose the capacity to grow intellectually. The individual begins perhaps with an education that puts him ahead of the majority of his competitors. As the years go on, he gradually fails, while other men go steadily forward to, greater accomplishment. It is not the sclerosis of old age stopping down the blood supply to the brain, but a sclerosis which overtakes the mind perhaps at the beginning of manhood. Material success may be attained, but intellectually life is at an end when the circle is closed and when there is no chance to enlarge its circumference. The intellectual life is the life of mental expansion, so that one cannot limit its boundaries and continue to live. The physician, who is too busy practicing to study either his patients or his journals, the clergyman, whose theology does not change with his ripening years, the college professor, who settles com- 
fortably into the same intellectual routine, all go the way of the closing mind which is so easy and so natural for mankind. When a man's opinions on complex problems do not change for a term of years, it is well for him to beware, if he has any ambition to be more than he has been. And the same might be said of nations.

How this intellectual slothfulness, which is the mark of the closed mind, affects society through the Church and through Government could be easily illustrated from the history of any modern country did space permit. The point of this discussion is, however, that science counts on the side of the open mind, and that the new ideas, by means of which advancement is effected, will fall on fertile ground only to the extent that open-mindedness prevails.

\section{THE VALUE OF SCIENTIFIC SKEPTICISM}

Usage has given the word skeptic a reproachful meaning. A term, which originally signified thoughtful or inquiring, has been so long used as a controversial epithet that it expresses an odious distinction. Frequently, the skeptic is mentioned as though he were an undesirable citizen. Now skepticism and its correlated attitudes of agnosticism and open-mindedness are intrinsic features of the scientific frame of mind. Skepticism, concerning that which cannot be accepted, without disregarding the facts of the case, is a commendable position. It is an attitude of mind which is unusual in a world where decisions must be made and action taken, and where lack of conviction exercises a paralyzing influence upon the conduct of an enterprise. We can be sure that the world will be full of the credulous rather than the skeptical, that those who doubt will continue to be a minority. But as we have seen, human progress has not been the product of credulity and the ignorant acceptance of unwarranted conclusions.

The popular usage of the term skepticism assigns it to the vocahulary of theology. We shall here use the term, in its 
more general sense, as ineaning thoughtful doubting of that which cannot be proved, and shall consider the significance of such a state of mind. What we shall try to show is that some measure of skepticism regarding present practice is the foundation for a spirit of toleration. The history of religious toleration, for example, shows that skepticism, regarding the authority for theological dogmas, was the force that finally curbed persecution. Conviction that he is right is part of the psychology of the persecutor. To doubt the grounds for one's convictions means eventually the collapse of intolerance.

Religious toleration is fairly well established in western society, but so-called heathen communities often exhibit a spirit which puts us to shame. ${ }^{9}$ If there is less of toleration within the politico-economic field, a reasonable degree is practiced, save in times of excitement when it appears that intolerance is very near the surface. This is perhaps because political and economic convictions matter so greatly in our practical world, while theological convictions have come to be regarded as unimportant. For example, if one is skeptical as to the perfections of the existing social order, and challenges the conviction that the founders of the nation possessed an omiscience enabling them to create a form of government which must remain unchanged, his mental attitude is far from unimportant in the eyes of the authorities. It not only irritates, by going counter to what has been assumed as a matter of course, it also suggests disagreeable possibilities, such as changes in material and economic conditions. Denunciation of skepticism is sound procedure for those who would maintain the status quo in any field, because skepticism eventually means toleration and hence possible modification of the established order.

The value of skepticism to the human mind lies in the fact that it creates the frame of mind, which is willing to break

${ }^{9} \mathrm{~A}$ forceful statement of the religious toleration existing in a certain East Indian state is given by Price Collier in "The West in the East," p. 274. 
with established convictions, and which, therefore, makes progress possible. Skepticism is part and parcel of the general scientific attitude of wanting to know and of wanting to know the grounds for knowing. The function of skepticism in relation to intellectual and other progress is that it challenges convictions which produce intolerance and end in persecution. The value, which inheres in a wholesome questioning of all authority as such, is so great that we can ill afford to decry the doubter. The skeptical individual, is the exceptional individual, because men tend to go with the herd. There is no danger that the skepticism which eventuates in group activities will undermine traditions that do not deserve destruction.

In a world of action, skepticism cannot go far without a rebound, since skepticism defeats its purpose when it results in doing nothing in an emergency. It is a thoroughly scientific procedure to recognize the importance of the skeptical frame of mind, and at the same time to recognize the paralysis that comes when skepticism degenerates into a pessimism that sees no solution and possesses no convictions. The cure for the impotent frame of mind, which is thus produced, lies in action. The doer must be in some measure a doubter of tradition, if his work advances to higher levels. When doubting ties the hands that will not long be tied, doubts are flung aside by the demand for doing. Every one knows that he must know he can do it to go on to victory, and there is this same attitude in the collective behavior of the group.

Historical examples, showing how skepticism has gradually replaced the intolerance of an earlier time by the toleration we now enjoy, will occur to the reader. The spirit of toleration exhibited by ancient Rome may be cited as a genuinely scientific quality of the Roman mind. The success of the Roman conquests was in no small measure due to the respect accorded to the beliefs of the conquered. The Roman outdid the Greek in this particular. The beliefs of 
Rome suffered in consequence. The spirit of toleration, which thus existed in ancient times, was followed by the intolerance and persecutions of the Middle Ages, which were only brought to a close by the changes in intellectual outlook resulting from scientific knowledge. As the spirit of truth-seeking became more prevalent, doubt arose. With the advent of doubt, persecution began to wane.

The persecutions sanctioned by the Medieval Church were an outcome of the doctrine of exclusive salvation. ${ }^{10}$ Since there was but one manner of salvation, the Church was justified in maintaining that it should "compel them to enter in." The justification of coercion being admitted, persecution followed. Pagan worship succumbed, the Jews in Europe were horribly maltreated, the attempts of Frederick II to found a humane culture in southern Italy were stamped out, the Protestant defection brought on the Religious wars. Protestantism proved little better. Calvin burnt Servetus because of his views regarding the Trinity. The Puritans in England and America persecuted those who did not accept their dogmas, and were in turn subjected to persecution following the Restoration. The first real step toward toleration in England was the growth of skepticism regarding the doctrine of exclusive salvation which had been at the root of persecution. The date of the Toleration Act (1689) is significant, although its passage was largely the result of political changes. Throughout this span of fifteen centuries, from the decline of the old to the appearance of the new spirit of toleration, it is evident that not one sect or group was at fault, but rather a frame of mind that gave unquestioning allegiance to traditional beliefs and that regarded as impious the doubts which eventually put an end to an insufferable situation. The history of the decline of belief in magic and witcheraft might be used in further illustration of the functions of skepticism. But the foregoing outline of the passing of religious intolerance will suffice.

${ }^{10}$ Lecky, W. E. H., "History of Rationalism in Europe." 
Historical analogies are valuable, because they are so generally accepted. But it may be doubted whether we actually learn anything from history, except as we find that history reinforces what is observed to be true in the present. Events, which are now transpiring in the world, are a better illustration of the contention that the foundation of toleration is doubt, and that without a degree of doubt neither religious nor any other form of toleration can exist.

The general politico-social situation which has been a product of the Great War exhibits points of interest. There is a parallel between what occurred centuries ago, as the outcome of an accepted theological dogma, and what is occurring at the present day as a result of the social dogma that political salvation can be secured only through the traditional forms of government. War is a period of intolerance in all lines. Having entered a struggle of life-anddeath importance the nation feels that those "not with us are against us," and at such a time it is idle to expect the same toleration of divergent opinion upon the matter in hand, as in less strenuous times. The most to be hoped is that the nation will not allow either its individual citizens or its constituted authorities to indulge in practices that will be cause for shame as soon as the excitement has subsided. War is, moreover, conservative, if not reactionary, in its influences, since it tends to make men feel that they should hold to what has been gained, and must, for the time being, put aside any thought of organic changes in government. Thus in Germany, while the war was on and likely to succeed, there was little chance for the social developments that were in the air before it began. The same was true in Great Britain and in the United States. A man fighting for his life has no time to examine the steps toward the expansion and elevation of individual existence. Political reaction is to be expected during war, and perhaps following war in the case of nations that are victorious. The problem is to bring 
about the return to conditions in which progress and not reaction is the watchword.

In times of reaction, the existing forms of government appear as the exclusive means of political salvation. Legalistic minds support tradition, and the general prejudice in favor of the existing has full sway. What is is right. Those who condemn it are in the wrong and should be dealt with. Persecutions, of the kind tolerated at the present day, are likely to follow. When to the uncritical deductions of the honest citizen there is added the support of those who profit financially by the situation as it exists, the outcome frequently gives no cause for congratulation. The aftermath of war has brought us to such a state in America, and there is no assurance that insidious survivals of this condition will not impede social progress for a generation to come. After the political offenders are released and the mobs cease to function, reaction may still dominate the nation.

Specific examples will occur to anyone who follows the history of current events. The thing to be criticised is, not so much the capitalists or the socialists or the bolshevists or union labor or the lawlessness of the mobs, as it is the frame of mind which accepts that which has been as the standard of what ought to be, and having done this, proceeds to condemn all who do not hold to this exclusive manner of salvation. Persecution naturally follows. As in the past, the decline of this state of mind, which is at the root of persecution, can come only when doubt is cast upon the underlying assumption that the traditional forms of organization and activity constitute the highest good.

Skepticism, therefore, appears to have its value. Beliefs possessing scant foundation cannot be made the basis for dogmatic assertion and its implied intolerance, when challenged at their source. Skepticism has been the most effective support of toleration in the past and it occupies a similar position in the present. The skepticism of science is not the trifling doubt of dilettantism. Science is thoughtful 
inquiry into the order of nature, human nature included. Thoughtful inquiry demands skepticism, wherever the grounds for a conclusion appear inadequate. Within its own field, science escapes the paralyzing effects of skepticism, because science is continually encouraged by its material accomplishments. It is, therefore, able to function undisturbed by the pessimism bred of abstract thought. Within the field of human relationships, skepticism becomes effective only where the facts make their meaning clear. The doubting mind, like the open mind, is the one through which comes progress and displacement of the idols of tradition.

\section{SCIENCE AND EMANCIPATION}

But even more important that its values as a material foundation, as a broader field for imagination and esthetic emotion, as an example of fair judgment and the open mind, and as the foe of persecution, is the value of science in the intellectual emancipation of mankind. The faith of science that truth makes men free has been more than justified. Many lesser cases might be cited, but a single comprehensive example of the emancipation, which has followed the spread of an important scientific doctrine, will suffice. The theory of organic evolution is the best illustration afforded by biological science, and perhaps by science in general.

As we have noted, the evolutionary theories current among the Greeks were tinctured with philosophy. Lacking concreteness, these philosophical concepts made little headway. The beginnings of modern evolutionism appear in the accumulations of facts regarding animals and plants, which marked the closing centuries of the Scientific Renaissance. To Buffon and to other less known writers of the eighteenth century belongs the credit for having first promulgated the evolutionary theory in a form that was scientific rather than philosophical, and that carried a measure of conviction, despite its crudities and the hamperings of theological 
criticism. One cannot turn the pages of Buffon's encyclopædic work without a growing respect for his knowledge of animal life. Obviously, the foundation for much of our comparative anatomy of vertebrates was even then established. In a preceding chapter it has been shown how Lamarck was the first to offer a theory of the causes of evolution and how he failed to make his case as against the authority of Cuvier; also how the latter, although opposing the theory of evolution, accumulated some of its strongest evidence, through his studies in comparative anatomy; and how von Baer supplemented this by his work in embryology. We saw, finally, that in Darwin's day, there were ample data for the establishment of the historical fact of evolution, if not for the determination of its causation. The almost immediate acceptance, in biological science, of Darwin's views and the spread of the evolutionary concept to other fields, during the remaining years of the nineteenth century, are well known. We are here concerned with the effect of the evolutionary doctrine upon human thought in the present and the possible extension of its influence in the future.

The triumph of the evolutionary concept completed the overthrow of those older ideas of the universe which culminated in medieval theology. Evolution was the final extension of that enlarging mental horizon disclosed by the fact of the earth's sphericity and the Copernican explanation of the solar system, conceptions which are indissolubly united and each of which represents a stride forward in the face of resistance. Copernicus would have suffered, as Galileo did later, had the full implications of his theory been recognized before his death. Buffon was not in physical danger, though forced to recant. Darwin, though heaped with abuse, suffered no real inconvenience at the hands of his critics, for he lived in a more tolerant and enlightened age.

During the three centuries involved, man's picture of himself changed from that of a being, recently created and 
awaiting a day of judgment in the not distant future, to that of a being originating as part of organic nature and set in a universe without beginning and without end. The byproduct of this intellectual revolution was an emancipation of the human spirit from the bonds of authority. Authority indeed remains, but it is no longer the authority of book or priest, however potent such authority may still appear to be. In its place stands the authority of nature; and so great has been the emancipation we have, as yet, recognized but an insignificant measure of the changes in human thinking which must follow.

While we can best visualize the effects of the evolutionary doctrine by reviewing its historical development, it is equally important that one recognize what is happening to-day; in what way this doctrine has affected theological beliefs since the publication of Darwin's "Origin of Species" (1859); what has happened in philosophy; and what changes have occurred in our outlook upon the problems of society.

In theology, the evolutionary doctrine is carrying us from the concept of a single religion, revealed to man by agents duly inspired, to the concept of a multitude of religions of varying worthiness, but all the outgrowth of yearnings which originated with human intelligence. In other words, religion of whatever sort is a product of organic evolution, just as human intelligence is a product of evolution. When religion is so regarded, we need not condone the shortcomings of the fathers nor strive for metaphysical explanations of sin and death, of sorrow and pain; since these are but the present outcome of our origin from the brute. We know in part whence we came, if not whither we are going, and it is enough if we may, by our own efforts, somewhat improve the material and spiritual state of ourselves and our children. This point of view has been reached, not by a sudden break with the past, but by a gradual shift of mental attitude which makes the older doctrines impossible of acceptance. The evolutionary concept has been 
applied to religion, as to every other expression of organic nature; and the result has been a revolution, accomplished before its beginnings were recognized. Thus science has brought emancipation from theological bondage, and set free the spirit of man for higher flights in the future.

In philosophy, the evolutionary theory has necessitated a change from the concept of a static to that of a dynamic universe, as witness the contrast between the philosophical systems of the early nineteenth century and the views of Bergson. ${ }^{11}$ This change has not yet completed its remodelling of philosophical theories. But only a philosopher can explain its workings in detail.

In the field of social phenomena, the influence of the evolutionary theory appears in the recurrent questioning of the necessity for existing conditions. If the revolutions of the later eighteenth and earlier nineteenth centuries attacked the foundations of civic power and sought to install the authority of peoples over that of kings, the unseen revolution induced by the evolutionary theory has shaken the whole edifice of social tradition. Whatever is may be the natural outcome of the evolution of society to date, but it is not thereby right nor is it necessarily permanent. The evolutionist may recognize the stability of social customs that have arisen by evolution; but he also recognizes these customs as subject to change. Moreover, the human race must consider the intelligent direction of its future evolution as a possibility, however remote. Evolution has not always taken the most desirable course, as witness the degeneration incident to parasitism; and while man will probably have little to do with its outcome in the human species, what he may do is worth considering.

The influence of the evolutionary concept may be seen

11 It does not seem to the writer that the ideas of Bergson are particularly enlightening to the biological scientist. They exhibit too much of mysticism. But they illustrate the advent of a philosophy which takes more cognizance of organic evolution. 
again in the attitude toward a variety of social problems. Disease and crime are not inevitable conditions to be treated by curative measures only. They are to be attacked with all the knowledge at our command, and finally eliminated by the evolution of a type of man and a form of society in which such evils will be non-existent. Man is no longer piously content with his lot, merely because he sees no prospect of immediately changing it. Conditions have changed in the past and mankind wants to change them in the future. Man is not content to let evolution take its course with him, he strives to make it go his way. Thus the insight into social problems which evolution has brought gives a habit of mind that will brook no limitation of the human spirit. As within the field of philosophy, so within the field of social phenomena, this changing point of view is an outcome of the recognition of a dynamic as opposed to a static world.

There is thus taking place, under the influence of the evolutionary doctrine, a subtle change of ideas and of beliefs, comparable to the changes of intellectual outlook in the past, by which superstitions, like infant damnation, witchcraft, demoniacal possession, and the belief in ghosts were rendered impotent. Such changes occur in what may be designated the frame of mind. They are, seemingly, effected not so much by argument as by the imperceptible growth of a conviction that the traditional belief is unreasonable. Old beliefs often persist, apparently in full vigor, until the collapse is at hand; but when beliefs begin to excite ridicule, their course is nearly run. The history of scientific progress has been marked by spiritual emancipations. To-day the process still goes on, for supernaturalism is not yet fully vanquished, but lingers on as a miasma of society.

In this manner, science feeds the spiritual as well as the material man. Science deals with that we can measure and weigh, is wholly impersonal, is a thing of intellect rather than of emotion. But intellect and emotion are not separate 
entities of the mind, rather the mind is a unit which has its intellectual and its emotional sides. The raw material of scientific fact is susceptible of unlimited organization within the mind, and this process of organization gives play alike to the intellectual and the emotional aspects of man's nature. If we have made our point, it has been shown that the progress of science has given the mind of man infinitely more than it has taken away. 


\section{MANKIND AND THE FURTHER PROGRESS OF SCIENCE}

AN attempt has now been made to delineate the place of science in human affairs. The materialities of civilized life rest upon scientific knowledge. The spirit of the modern world is the rationalistic spirit of science. Mankind is becoming increasingly dependent upon the creations of hand and mind which science has brought forth. If vast populations must be artificially fed and clothed, science becomes a necessity in the lives of men. The extent to which mere physical demands should be satisfied may be questioned, but once established they become insistent. On the material side, the science of the future must concern itself with facts of serious import regarding exhaustion of natural resources and increases of population. The mad expenditure of human effort in pursuit of the material luxuries of civilized life cannot continue indefinitely, unless new sources of energy are discoverable. But even in that event, men may become convinced that such effort is not worth while; since satisfaction of physical needs is not the highest human aspiration. Science has this more lasting significance-well-balanced lives can be lived only in the scientific spirit. The great problem of the scientific future is spiritual adjustment, not physical gratification. Although nothing seems able to stand against material matter-of-fact, this aspect of science must eventually occupy a subordinate position. A brief consideration of certain possibilities concludes the discussion.

It is sometimes declared that science has reached the point of diminishing returns, that future advances cannot 
equal those already made. The easier work has all been accomplished, and hence substantial progress will shortly come to an end. Never again can there be such a period as the recent centuries. Without venturing a prophecy, these statements may be challenged, in so far as they express conviction that the greatest triumphs of science lie behind us. Such pessimism is foreign to biological science and we doubt its existence in other lines of scientific effort.

The ultimate goal of scientific endeavor is conquest of the universe, in so far as this is demanded by human welfare and aspiration. Despite seeming pretension, science is not vainglorious. New and more difficult problems arise from each problem solved. There seems no immediate nearing of the goal. The Cosmos we know to-day is unbelievably complex and more is being disclosed. Things undreamed of in our philosophy continually appear. Consider, for example, the concept of a super-universe, which has arisen as an outcome of recent astronomical investigations; and the Theory of Relativity.

Nature still presents unlimited problems, and the desire for intellectual dominion is a guarantee for the continuation of scientific effort in the future. The biological discovery of man's place in nature did more than change traditional beliefs; it gave a point of departure into a future, unknown but fraught with possibilities. Mankind has grasped the idea of controlling nature through understanding of natural law. And once this lays firmer hold upon imagination, there will be no satisfying of desire save by the advancement of scientific knowledge. The permanent future of science seems assured, in so far as human inclination is concerned. Neither lack of incentive nor exhaustibility of unexplained phenomena will check its progress, but rather the limitations of human understanding.

There is no positive evidence for a progressive evolution of human intelligence during the recent centuries. The race is apparently at a standstill in this particular, unless, indeed, 
regression may not be in progress, as a result of recent material changes in civilized life. The absence of precise data precludes extended discussion, but a permanent equilibrium would have such momentous consequences that mere indications should not be disregarded. If we can obtain even suggestive evidence, by comparison of the mental product of the present day with that of the past, or in any other manner, the facts are worthy of consideration.

Comparison indicates that human mentality of to-day does not differ appreciably from that which existed in the dawn of written history. Discounting present capacity in terms of cultural heritage, the wise and foolish seem to have been distributed in much the same proportions during many centuries. If defectives were less gently handled in primitive times, it tended to raise the average. But since the progressives were as commonly repressed, little change was effected. Neither do the physical features of mankind offer conclusive evidence of evolution during the centuries in question. Resistance to certain diseases is probably an instance of progressive modification. But this is being nullified by the curative and preventive measures which medical science has recently placed at the disposal of society. ${ }^{1}$

The individuals who exhibit high mentality at the present day seem, therefore, to possess no greater capacity than did those of earlier times. A modern boy may easily know more fundamental facts of natural science than did any of the Greek philosophers, but there is not one chance in a million that he will become their equal. Modern men of ability do not seem superior to those of antiquity, in view of accomplishment under different conditions. As for the average intelligence of to-day, the biologist challenges all claims that inherent ability has changed perceptibly during thousands of years.

The superiority of the ancient Greeks did not consist

${ }^{1}$ Reid, Archdall, "The Principles of Heredity," 1896; Holmes, S. J., "The Trend of the Race," 1920. 
in the possession of minds greater than any which have appeared elsewhere, but in the presence, within a small population, of a greater proportion of able individuals. One competent critic declares that the average ability among the Athenians in the period of their glory was as far above that of Englishmen at the present time as the average ability of the English is above that of African negroes. ${ }^{2}$ Accurate comparison is, of course, impossible, but judged by intellectual accomplishment the statement seems no exaggeration. So far as the evidence goes, the European races have not advanced, either in average or in exceptional intellectual capacity, since the days of the Greeks, perhaps not since the decline of the Crô-Magnards. ${ }^{3}$

The biological significance of such a conclusion is obvious. It creates a justification for eugenic propaganda. For the present purpose, we merely point to the limitations that may be placed upon scientific progress by the absence of minds, which exceed the capacity of any that have preceded them, and by a lowered average of mentality in whole populations. There is danger here for science as well as for society. The advancement of science is more likely to be checked by such limitations of the human mind than by exhaustion of unsolved problems.

Hope for an unlimited advancement of natural knowledge lies in the biological possibility that the human species has not reached an equilibrium with respect to intellectual ability, even though it may seem to have been at a standstill

2 "It follows from all this that the average ability of the Athenian race, is, on the lowest possible estimate, very nearly two grades higher than our ownthat is, about as much as our race is above that of the African Negro." Galton, F., "Hereditary Genius," 1892 Edn., p. 330.

${ }^{3}$ The Crô-Magnards were the highest of the cave races of Europe. They finally disappeared sometime within the past twenty-five thousand years. In skull capacity (1800 c.cm.) some of the individuals discovered seem slightly to exceed the best races of modern times. Although they could not have been other than savages, when judged by present standards, their physical features and perhaps their inherent mentality were remarkable. Osborn, H. F., "Men of the Old Stone Age," p. 299. 
for some thousands of years. The idea of a superman is more than a subject for jest to those who look into the future and who recall the races of the Eurasian continent before the appearance of Homo sapiens. The advance of science may, indeed, be checked by the present level of intelligence. But further evolution may remove this limitation.

As for the immediate possibilities in biological lines, it is necessary only to trace the growth of scientific knowledge and become familiar with current investigations to appreciate the promise of the morrow. The nineteenth century brought revolutionary advancement in the physico-chemical field. The twentieth century bids fair to witness similar progress within the domain of biology. Not only the medical aspects of biological science, but its social aspects as well, offer startling possibilities. The results that may eventually flow from the eugenic and euthenic principles already established are difficult to picture. Biology seems to be entering upon a period in which many of its current problems may be solved. Whatever their solution the results will benefit mankind.

As we have seen, control over nature is merely acquiescence in nature's laws and the ordering of human affairs in such fashion that nature serves the needs of man. The winds and waves obey us, in so far as we effect adjustments whereby they accomplish our purpose. In the past, control has been extended mainly within the domain of inanimate nature. Relatively little has been accomplished with respect to vital phenomena; but men have caught the vision. Because they have dreamed of a glorious nearfuture, many of the present generation wish they might live out the present century and play a part in the eradication of disease, the prolongation of human life, and all the attainment which seems within reach. Just as the existing mastery of non-living nature has become possible through scientific knowledge, so must the control of living nature be accomplished. In the long run, such a result is capable of bringing greater happiness than mankind has ever known. 
What science intends, both for the immediate and the remote future, is to keep going. The scientist believes that his rationalistic method offers a means of moving forward, which sets no limit and sees no end. He is content to maintain the advance without undue speculation regarding immediate or ultimate goals. There are plenty of problems within vision, and many opportunities for applications of the facts now established. Most to be feared is a frame of mind that discourages investigation, for example, any widespread conviction that certain classes of problems cannot be solved. Whether he advances knowledge or not, the individual scientist is determined to keep trying; for it is his creed that to try persistently will in time produce worth while results.

The future of mankind seems likely to be a scientific future. Modern culture has come into being through science and through the control of natural phenomena, which is bred of scientific knowledge. The rationalistic scientific spirit is the spirit of the modern world. Any thinking man can comprehend the relation of science to human affairs, although comprehension may demand reversal in mental orientation. Science is the product of human reason applied to the phenomena of nature, human nature included. Its course has not been run. The future is bright with a promise that stands at the threshold of realization. Ignoring of science by one generation bars the door of progress and the next generation suffers accordingly. Understanding of science is the greatest legacy we can bequeath to posterity. 



\section{INDEX}

Abelard, 54

Academies of Science, 89

Acquired characteristics, 169, 170

Adams, G. B., 50, 67, 82

Adaptation, 171-172

"Admirable Doctor," the, 62

Adriatic sea, 78

Advertising, 281

Egeans, 19, 26, 27

Agar, 128, 130

Age of Reason, 115

Agnosticism, 302

Agobard, 53

Agricultural Revolution, 106

Albertus Magnus, 60

Alchemy, 36, 83

Alexandrian Library, 35, 56

Alexandrian Museum, see Museum

Alfonso, King, of Naples, 82

Algebra, 57, 58

Al-Mamun, 56, 57

American Museum of Natural History, 185

Amma, 130

Anatomy, comparative, 165, 173, 182, 184

Andalusian fowl, 135, 136

Animalcules, see Microörganisms

Anthrax, 150

Antipodes, 51-52, 61

Antisepsis, 152

Apes, 99

Applied science, 107-108

Arab Conquest, 55, 56

Arab culture, characterization of, 58

Arab science, $36,53,54,56,59,67,90$

Archimedes, 32, 35

Aristarchus, 32

A ristocracy and science, 28:3-289

Aristotle, 33, 34, 62, 63, 64, 68, 84, 230,241

Arithmetic, 23, 24, 27

Arkwright's water frame, 105

Asepsis, 152

Astrology, 24, 76, 81

Astronomy, 24, 57, 62, 64, 72, 83, 94,96

Athenians, 28, 317

Atomic Theory, 33, 97, 98
Authority, 4-8, 310; see also Tradition

Automobile, 62

Averroes, 58, 64, 76

Avicenna, 58

Awareness, 213

Babylonian science, 3, 23

Bacillus of tuberculosis, 152

Bacon, Francis, 62, 74, 91, 106, 111, 112,230

Bacon, Roger, 58, 62-63, 65, 67, 68, $90,91,106,112$

Bacteria, 85, 247

Bacteriology, 120

von Baer, K. E., 173, 197, 309

Bagdad, 56

Baikie, J., 26

Baptism, 51

Barbarians, 60

Basil, 47

Bates, 215

Bayle, 113, 114

Behavior of Animals, 210-214

Berbers, 59

Bestiaries, see Physiologi

Bible, see Scriptures

Biblical traditions; sec Scriptures

Binomial nomenclature, 98

Biogenesis, 242, 248

Biological science and modern thought, $10,73,84,95,119-120$, $149,217,318$

Biological Station, Fairport, 256

Biology and medicine, 218

Blanckenhorn, M., 13

Blood tests, 182, 184

Boccaccio, 77

Botanical gardens, $36,84,85$

Botany, 84, 217

Boyle, 72, 83, 97

Brahe, Tycho, 72

Breasted, J. H., 13, 21

Breeding of animals, 87, 257, 259

Brooks, W. K., 88

Browne, C. A., 32, 36, 48

Bruno, Giordano, 74

Buckle, 263

Buffon, 99, 163-164, 168, 177, 308, 309 
Burckhardt, J., 53, 54, 87, 297

Bureau of Fisheries, U. S., 255

Burials, early Egyptian, 17

Burnett, James, see Monboddo von Buttel-Reepen, H., 11

Cairo, medical college of, 57

Calendar, 18, 23, 62

Cancer Laboratory, Buffalo, 249

Cards, dealing of, compared with development, 195

Carlyle, Thos., 263

Carpenter, W. B., 177

Cartesian doubt, 112

Cartwright's power loom, 105

Carus, J. V., 50

Castelli, 89

Catastrophism, 174-175

Catastrophists, 176

Cattle, hornless Egyptian, 19

Causation, 6, 31, 33, 223, 238

Cell, 120-122, 233

Cell-doctrine, see Cell-theory

Cell-lineage, 125

Cell-theory, 84, 94, 98, 100, 120, 121, $123,142-146,153,155,189,234$, 248

Celsus, 47

Cereals, early Egyptian, 17

Chaldean records, 23

Chambers, Robt., 177

Charlemagne, 60, 68, 90

Charlemagne's Reformation, 53

Chemical combination, theory of, 94,97

Chemical science, $35,57,72,83,97$

Child, C. M., 200

China, 11

Christianity, 42, 44, 45-46, 49, 56

Chromatin, $122,127,196$

Chromosomes, 127, 128, 131, 191, 203; and color blindness, 207-208; and heredity, 127-134, 142-144, 207 ; and sex, 205-208; in man, 207

Church of Rome, 60, 110

Circulation of blood, 84, 247

Circumference of earth, 58

City beautiful, 80

Civilization, analysis of, 263; as dependent on science, 10 ; as affected by science, 263 ; beginnings in Egypt, 16-22; continuity between Greek and earlier cultures, 28

Classical language requirements, $6-7$ Classification, $87,98,120,163,177$, 182,240
Clement IV, 63

Climate and culture, 21

Clodd, E., 163

Closed mind, the, 301

Cnossus, Hill of, 25

Coincidences and laws of science, 239

Coker, R. E., 256

Collier, Price, 303

Color blindness, 207-208

Columbus, 71, 161

Combustion, 98

Commerce and science, 11, 67, 102104

Common sense and science, 230-237

Commonness in sense-experience, 227

Compass, 58

"Compel them to enter in," 114

Compounds, chemical, 83,97

Compton's muslin wheel, 105

Comte, 263

Conklin, E. G., 125, 172, 195

Consciousness, 213

Conservation of Energy, 94, 97

Conservatism $v s$. spirit of science, 272

Constantinople, 69

Contagion, 151, 248

Control of nature, through science, $4,9,45,62,74,91,106-109,111$, $149,219,261,267,315,318,319$

Copernican Theory, 7, 39, 82, 161, $186,298,309$

Copernicus, 35, 72, 75, 82, 83, 96, 161,309

Corot, 79

Cosmas, 51-53, 158

Cosmogony, $3,75,155-162$

Cosmos, 31-32, 40, 75, 158, 315

Coster, Laurens, 74

Cotton, 23

Counter Reformation, 110

Crete, 25-26

Cretans, see Ægeans

Critical spirit, 74, 76-77, 90

Cro-Magnards, 317

Crozier, J. Beattie, 266, 267

Crusades, 59, 67, 68

Ctesibius, 35

Cultural level, as influenced by science, 268-269

Cuvier, 172, 173, 175, 309

Cytology, 202-204; see also Cell, and Cell-theory

Cytoplasm, 122, 134

Dallinger, 248

Dalton, 98

Dante, 34, 75-76, 297

Dark Ages, 42-55 
Darwin, Chas., $98,156,166,173,175-$ $181,186,217,211,214,272,309$, 310

Darwin, Erasmus, 166

Darwinian theory, 168, 173-186

Darwinism to-day, 180

Daubenton, 165, 173

Day of Judgment, 175

Death and old age, 201-202

Debate of 1830,173

Deists, 110

Deluge, 79, 162-163

Demagogue vs, thinker, 272

Democracy, 30, 283-289

Democritus, 32, 40, 97

"De Naturis Rerum," 85, S6

"De Rerum Natura," 40, 161; see also Lucretius

Descartes, 74, 75, 83, 110, 112, 113 , 210,272

"Descent of Man," Darwin, 179; see also Man's place in Nature

Determiners, $140,142,144,145$

Determinism, 212

Development, 123, 125-126, 188202, 192, 195-196

"Development Hypothesis," Spencer, 177

Devil, 62

Dias, Bartholomew, 71

Dickinson, G. Lowes, 30

Diderot, Denis, 164-165, 166

Differentiation see Development

Diminishing returns, point of, 314

Disease, 20, 100, 149-153

Domestication of animals and plants, $17,20,182,184$

Dominance, 136-137

Donation of Constantine, 82

Draper, J. W., 23, 36, 57, 89

Driesch, Hans, 211

Drosophila, 131, 132, 133

Drysdale, 248

Duns Scotus, 64

Dürer, Albrecht, 72

Earlier Renaissance, 53

Ecology, 120, 216

Economic development, 74

Education, 6, 274

Egypt, physical conditions of, 21; see also Nile Valley

Egyptian culture and science, 3, 1122,274

Egyptian race, 1S, 21

Eighteenth-century science, 101

Elements, chemical, 97, 83

Elephant, evolution of, 183, 184
Elixir of life, 36, 59

Emancipation and science, 308-313

Embryology, comparative, 173, 182, $184,186,188$; see also Development

Empedocles, 32, 33, 160

Encyclopædists, 96

Energy, 97

English, intellectual ability of, 317

Environment, 4, 169

Eoliths, 16

Epicurean philosophy, 40

Epigenesis, 145, 164, 193-197

Esthetic appreciation, 295-298

Ether, 98

Eugenics, 259-261, 317

Europeanization of world, 103

Eusebius, 47

Evans, Sir Arthur, 26

Evolution, 75, 94, 98, 99, 120, 145, 155-156, 292, 298; and philosophy, 311 ; and religion, $310-311$; and social phenomena, 311-312; and theology, 310-311; causes of, 167168 ; coming of, 176-179; confusion between fact and causes of, 168; cosmic, $96,155,156$; evidence for, 182; geologic, 156, 164, 173; Greek speculation on, 31-33, 159; human, 160; influence of the concept, 308-319; influence upon studies in animal behavior, 211; of elephant, 183, 184; of horse, 184 , 185; organic, $94,98,99,120$, 155-156, 161, 163; present status, 186 ; theory and cell-theory compared, 153, 155

Exclusive salvation, 305

Experimentation, in Arab science, 57 ; in medical science, 218; in social sciences, 271; in zoölogy, $187,195,197,208,214$

External world, 225

Ewing, J. A., 105

Factors, see Determiners

Factory system, 104

Facts of science, 5, 7, 223-229

Fair judgment and science, 298-299

Families, 98

Farnell, L. R., 30

Ferrero, Guglielmo, 45

Fertilization, 122, 127, 129, 188-193

Fire engine, 35

Flint workers, 11, 16

Flood, see Deluge

Florence, 87

Flying machine, 62, 79 
Flying shuttle, 105

Fossils, 78, 79, 159, 161, 174, 175, 176

Frederick II, 305

Freedom, as established by Renaissance, 92

French Revolution, 278

Fresh-water mussel, 252-253

Frog, development, 124-126; skin gland, 147

Galen, 5, 39, 84

Galileo, 35, 72, 82, 83, 96, 101, 309

Galton, Francis, 257, 317

Galton's analysis of heredity contrasted with Mendel's, 257-258

da Gama, Vasco, 71

Gametes, see Germ-cells

Geikie, Archibald, 176

Genera, 98

Genes, see Determiners

Genesis, 157, 292

Genetics, 202-204

Genius, individuals of, $74,75,81,317$

Genus, 33

Geo-centric theory, 82

Geographical discoveries, 67; distribution, 162-163, 182, 184; science, $35,71,83,96$

Geography and racial traits, 61

Geological science, 35, 78, 79, 156, $173,175-176,177$

Geologist, illustration of, 232

Gerbert of Rheims, 54, 58, 62

Germ-cells, 126, 140, 203

Germ diseases, 246, 248-249

Germ-theory of disease, 101, 149-153

German science and industry, 108

von Gesner, Conrad, 73, 87

Gilbert of Colchester, 71

Giovanni Pico della Mirandola, 74, 81

Glacial Period, 11, 12, 13, 16

Glaser, O. C., 192

Glochidium, 252; theory, 254

Gnosticism, 49

God, 5, 30, 47, 50, 75, 157

Goose barnacles, 61

Gonzaga, Francesco, Duke of Mantua, 87

Government as influenced by science, 282-289

"Grand Age," of Crete, 26

Gravitation, 83, 96

Great God Business, 279

Great War, 306

Greco-Roman culture, continuity with Egyptian and Mesopotamian, 18,22
Greece, antecedents of, 25; intellectual failure of, 31-32

Greek, ideal of life, 9, 30; mind and modern science, 31; mythology as basis for imagination, 293; science, $3,29,274$

Greeks, intellectual superiority of, $316-317$; origin, 27 ; racial stock of Athenians, 28

Grenada, 89

Grew, 121

Guizot, F., 263

Gunpowder, 58

Gutenberg, 74

Guyer, M. F., 171

Haldane, J. S., 211

Hargreave's spinning jenny, 105

Harmony, spiritual, of Greece, 37

Harris, D. F., 247

Harvey, 73, 84, 247

Hawes, C. H., and H. B., 26

Heated air engine, 35, 105

Hebrew-Chaldean traditions, 157159,161

Hegel, 263

Hellenes, see Greeks

Hellenistic Age, 37, 58

Henslow, G., 170

Herbert, S., 170, 184

Heredity, 181, 195, 219，256-261; and variation, as cell-problems, 145; cellular basis of, 126-145; chromosome theory of, 127-134, 142-144; sex-linked, 208

Hero of Alexandria, 35, 105

Hertwig, Oscar, 189

Heteromorphosis, 198

Higher Criticism, 7

Hindu science, 56

Hindus, 57, 58

Hippocrates, 32, 36, 39

"Historie Naturelle," Buffon, 165

Histology, 85, 120

"Historia Animalium," Gesner, 87

Hobbes, 74

Hohenheim, Philippus von; see "Paracelsus"

Holmes, O. W., 152, 249

Homeric Tales, 27

Hooke, 121

Hooker, the botanist, 179

Hornaday, W. T., 215

Horse, domestic, 23; evolution of, 184,185

Howard, Sidney, 278

Human intelligence, evolution of, 315-317 
Human progress, means to, 266; influence of the cultural level, 266; ineffectiveness of exhortation, 266

Humanism, 9, 76, 89, 92

Humanistic philosophy, 6, 9, 40

Humanists, 73, 76-77, 82

Humbolt, 177

Hume, 112, 113, 165

Hutton, 79, 165, 173, 174, 176

Huxley, T. H., 112, 210, 230

Hypatia, 48

Ice-age; see Glacial Period

Image Worship, 46

Imagination and science, 291-295

Impersonal thinking, 299

Implications of science, 114-115

India, 11, 274

Individual, expansion and elevation of, 263

Individualism in society, 287

Inductive sciences, 91

Industrial Revolution, 95, 104, 107, 109

Industrialism and science, 278-279

Industry in relation to science, 95, 102-109

Infidels, 67

Innovation, 301

Insects and disease, 152

Intolerance, 109, 302-309

Introspection, 213

Intuitions, 227-229, 237

Invention and the Industrial Revolution, 105

Inventor vs. the scientist, 107-108

Iron, 23

Islam, 59

Italy, 67

Japan, 274

Jastrow, J., 25

Jenner, 100, 151

Jennings, H. S., 202, 212

Jesus, ethical teachings of, 45-46

Jews, 57,59

Joachim of Flora, 54

Johnson, Dr. Samuel, 165

Jones, W. H. S., 45

Journalism, 280-281

Kant, 112, 113

Kay's flying shuttle, 105

Keen, W. W., 152

Kellogg, V. L., 180

Kent, W. Sayville, 247

Kepler, 72, 75, 83

King, H. D., 205
Kipling, R., 245, 294

Knowledge, objective, 229; of science, 223-229, 237; subjective, 229

Koch, 152

Koran, 56

Kramer, Gerhard, "Mercator," 71

Lamarck, 166, 167, 168, 172, 173, 309

Lamarckian hypothesis, 99, 167-172, 177

Lang, A., 210

Lankester, E. Ray, 112, 294

Laplace, 96

Lavoisier, 98

Law; see Legalistic

Lawyer in government, 287

Laws, of science, 238-240

Lecky, W. E. H., 46, 51, 76, 113, 305

Lecler, see Buffon

Lee, F. S., 149

Leenwenhoek, 73, 85, 247, 248, 249, 250,255

Lefevre, George, 202

Lefevre and Curtis, 251, 252, 253, 255

Legalistic frame of mine, 275-282

Leibnitz, 74

Leonardo, da Vinci, 74, 77-83, 101, $112,161,243$

Leone Battista Alberti, 74, 82

Leydig, F., 255

Libby, Walter, 32

Life, origin of, 33, 99

Lillie, F. R., 189, 190, 191, 209

Linkage in heredity, 132-133

Linnæus, 98, 163, 167

Lions, 86

Lister, Lord Joseph, 151

Locke, 74, 112, 113

Locy, W. A., 85, 86

Loeb, J., 192, 202, 211

Logic, 31, 230, 237

Lombardy, 78

Lovejoy, A. O., 96, 99, 164, 165, 177

Lubbock, Sir John, 211

Lucretius, 40, 97, 160, 161

da Luzzi, 84

Lyell, Chas., 173, 175, 179

Machine, earliest known, 20

Magellan, 71

Mahaffy, J. P., 29, 36

Malaria, 45, 152, 296

Malpighi, 85, 73, 121

Mankind, in relation to science, 319; see also Control of Nature

Man, palæolithic, 11; pliocene, 16; pre-chellean, 16

Man's place in nature, $10,99,156$, 
$160,165,179,186,202,293-294$, 309,315

Man's relation to nature, 111

Mariolatry, 46

Mast, S. O., 211, 212

Matarazzo, 87

Material foundations of society in relation to science, 264-269

Material progress in relation to science, 107-109

Material vs. spiritual influences of science, 4, 9, 114-115, 290

Mathematical science, 58, 72, 83, 84

Mathematics and philosophy, 74

Matter, 32, 97, 98

Maupertuis, 164, 165, 166

McCurdy, E., 79

Mechanistic conception of life, 210213; conception of nature, 112

Medical science, 76, 94, 100, 228

Medicine, and biology, 218; chemical, 83

Medieval, craftsman, 5; frame of mind, 52, 54, 63-64, 65, 68, 90, 92,305 ; science, $4,53-55,85$

Mediterranean race, 27,38

von Megenberg, Conrad, 85, 86

Mendel, Gregor, 257, 258, 259

Mendelian heredity, 134, 139-145, $197,203,296$

Mendel's analysis of heredity, contrasted with Galton's, 257-258

Mendel's Law, 203, 204; rediscovery of, 258

Menageries, see Zoölogical Gardens

Mercator, 71

Meriam, J. C., 11

Mesopotamia, physical conditions, 22

Mesopotamian, civilizations, 18, 22, 274 ; peoples, 22

Metal implements, 17

Metcalfe, M. M., 61

Metchnikoff, E., 202

Method of science, 230-238

Mice, dominance of gray over white, 136

Microörganisms, 95, 100, 150, 246250,247

Microscope, 62, 84, 95, 247

Microscopy, 84, 88, 247

Middle Ages, 42, 49-50, 53, 60, 65, $67-69,297$; see also Medieval

Mill, J. S., 230

Mina, 23

Minoan civilization, 25

Miracles, 110

Mitchell, P. C., 202

Mitosis or Mitotic cell division, 128
Modern Scientific Period, 60, 94

Mohammedan, see Arab, 67

Molecules and atoms, 98

Monasteries, 55

Monboddo, Lord, James Burnett, 165

Monotheism, 30

Montaigne, Michel, 74, 113

Moors, 59, 89

Moorish Kíngdom, 56

Morgan, T. H., 133, 186, 196, 199 , 208

Mosquito-malaria theory, 152, 296

Munro, H. J. A., 40, 161

Murray, Robert, 61

Museum at Alexandria, 35-36, 39, 58

Muslin wheel, Compton's, 105

Mussel, fresh-water, 250-256

Mycenæ, 26

National Research Council, 244

Natural history, $84,88,214-217$

Natural law vs super-natural, 110; see also Superstition

Natural resources, 314

Natural Selection, 40, 168, 172, 178, $179,180,181,186$

Naturalism, 91, 110

Nature, control of by man; see Control of Nature

"Nature's Insurgent Son," Lankester, 294

Nature-scarcher and the explorer, 245

Nature Study, 216

Near East, 11, 25, 103

Nebular hypothesis, 96

Negroes, intellectual ability of, 317

Neo-Weismannism, 197

Nestorians, 57

Newcommen's steam engine, 105

Newton, Isaac, 72, 75, 83, 96, 97, 296

Nile Valley, 13-15; see also Egypt

Nordic race, 27,38

Normative sciences, 237

Notation, see Numerals

Nucleus, 122; vs. cytoplasm in heredity, 134

Numerals, 23, 24, 37, 57

Objective reality, 224, 237

Observation, in Arab science, 57; in zoölogy, 187; see also Experimentation

Old age and death, 201-202

Omar, Khalif, 56

"Omne vivum ex ovo," 235

"Omnis cellula e cellula," 189

Oösperm, 130

Open mind, the, 299 
Open-mindedness, 270, 302

Organization of germ, 195-197

Organized science, 3

Origen, 48

"Origin of Species," 98, 166, 173, $175-180,186,310$

Osborn, H. F., 11, 34, 160, 317

Ovists, 189

Ovum, 122, 127

Pacioli, 72

Packard, A. S., 170

Paganism and Christıanity, 45-46

Paracelsus, 73

Parasites, 149

Parasitology, 218

Parker, G. H., 145

Parthenogenesis, 190-191, 201, 202

Pascal, 74, 83

Pasteur, 150, 151

Pathology, 120

Pearl button indust ry. 25.5

Pearson, Karl, 225

Pergamum, 39

Persecution, 54, 109, 113, 114, 303, 305,307

Perugia, 87

Peter of Apono, 76, 82

Petrarch, 76, 82, 89, 297

Philistines, 27

Phillips, E. F., 190

Philosopher, influence of the, 113; in relation to science, 111

Philosophers, 159, 166, 167

Philosopher's stone, 59

"Philosophie Zoölogique," 167, 170

Philosophy in relation to everyday life, 113; evolution, 311; religion in Greece, 30-31; science, 111, 113, 223 ; theology, 74

Philosophy, of scholasticism, 68; origin of modern, 112; The Aristotelian vs. Platonic, 34

Phlogiston-theory, 83, 97

Phonicians, 19, 102

Physical degeneration of Romans, 44

Physical science, 72, 83, 84, 94, 97, 119

Physico-chemical study of biological phenomena, 218

Physiologi, 50, 76, 85, 87

Physiological processes, cellular basis of, 146-149

Physiology, 84, 182, 183

Platonic philosophy, 34

Pliny, the elder, 39, 78

Plow, 20

Po river, 78
Polarity, 198, 200

Post-Darwinian Period, 167, 171

Postal system, 23

Potter's wheel, 20

Pottery, 17

Pound, 23

Poverty, 298

Power-driven machinery, 105

Power loom, Cartwright's, 105

Practical inventions, 104

Practical needs in relation to theoretical knowledge; see Theory and Practice

Practical vs. theoretical knowledge, 104,106 ; see also Theory and Practice

Preformation, 145, 164, 193-197

Presence-and-absence theory, 137

Preyer, 211

Primitive ideas of Cosmos, 75; see also Cosmogony

Prince Henry, the "Navigator," 71

Printing, 74

Probability, theory of, 74

Professional growth, 301

Progression, in geological record, $\mathbf{1 7 6}$

Propaganda, 280-281

Protective resemblance, 172

Protoplasm, 121, 123

Protozoa, 85, 152, 247, 248

Protozoölogy, 218

Providence, visitations of, 100

Psychology, 280

Ptolemaic system, 241

Ptolemy of Alexandria, 35, 39, 82

"Puch der Natur," 85, 86

Pure science, 107-108, 250

Puritans, 305

Pyramid Age, 20

Quarryman, illustration of, 231

Race suicide of Romans, 44

Radium, 97

Rationalism, 65, 74, 75-91, 94, 95, $110,111,114$

Ray, John, 73, 88

Reality, internal and external, 223227

Reality, scientific, 227

Recessive, 139

Red headed man on horse, illustration of, 239

Redi, 73, 85, 100, 188

Reformation, 82, 91, 110

Regeneration, 198-200

Regulation, 198, 200

Reid, Archdall, 316 
Relativity, theory of, 315

Religion, and evolution, 310-311; and Philosophy in Greece, 30-31; and science, 7-8, 24-25, 30, 4349, 310; natural, of Deists, 110 ; past and future, $7-8$

Renaissance, 5, 55, 59, 66, 264308 ; and establishment of modern science, 66,82 ; cultural antecedents, 67-69, 70-75; earlier and later periods of, 70, 77; extent as a scientific period, 66 ; science of in contrast to modern, 70; scientific discoveries of, 112; significance for science, $66,69,95$; summary of its accomplishments, 90-93

Research laboratories, 249

Revelation, 7, 310

Revival of Learning, see Renaissance Revolution, French, 91; Industrial, 95; spiritual induced by science, 4; see also Science and Scientific Revolutions, religious and political, 92

Rheims, 54

Riddle, Oscar, 209

Rockefeller Institute, 249

Roman culture, 38-39; notation, 58 ; science, 40, 43-44

Romanes, G. J., 180, 184, 211

Romans, $37-38$

Rome, decline of, 43-45

Royal Society of London, 89

Russian Revolution, 278

Sahara, 12

Salerno, medical college of, 57

Saltness of sea, 79

Satan, 54, 62, 63

Savery's steam engine, 105

Schleiden, 121

Scholastic vs. seientifie system, 112, 113

Scholasticism, 64-65, 68, 77, 88, 90

Schoolmen; see Scholasticism

Schools, among Arabs, 56; of Charlemagne, 90

Schultze, 123

Schwann, 121, 123

Science, as advanced by the philosopher, 111; beginnings of modern, 32,82 ; broader influences of, 114; characterizations of, 3 , 78, 114, 230, 263; during Modern Period, 4, 9, 101, 109, 115; implications and extensions of, 114-115, 166 ; influence upon government,
282-289; intentions of, 319 ; its influence upon frame of mind, 312-313; position of modern, 114115; practical values of, 314 ; pure and applied, 243-244, see also Theory and Practice; vs. scholasticism, 112, 113; spirit of, vs. conservatism, 272; in education, 273-274; vs. supernaturalism, 267268; the ideal of, with reference to state of mind, 301

Science in relation to, aristocracy, 283-289; advancement of civilization, 263-264; commerce, 102104; common sense, 230-237; cosmogony, 3, 75, 155-162; democracy, 283-289; emancipation, 308-313; esthetic appreciation, 295-298; fair judgment, 298-299; future of mankind, 319; good citizenship, 270; human reason, 3, 319 ; imagination, 291-295; industrialism, 278-279; industry, 102-109; material foundations of society, 264; modern philosophy of life, 9; modern thought, 4; persecution, 109; philosophy, 97, 111, 113, 223; religion, see Religion; social problems, 298-299; social progress, 269; superstition, 74 ; toleration, 109

Scientific, awakening, summarized, 90-91; certainty, nature of, 238239 ; facts, 223-229; frame of mind, $268,270,273,282 ; v s$. the legalistic, 275-282; generalizations, 238-240; hypotheses, illustrated by celltheory, 153; knowledge, 223-229; laws, 3, 238-240; method, 82, 230238 , 268; spirit, $3,42,299,314$; truth, 240-241

Scientist, in government, 280; $v 8$. the inventor, 107-108

Scientists, their appreciation of meanings, 166-167

Scott, W. B., 174, 183, 184

Scriptures, 5, 8, 7, 47, 51-53, 63, 68, 309-311

Secretion, 146-148

Secularization, 67

Sedgwick, W. T., 23, 31, 32

Segregation in Mendelian heredity, 134-136, 139, 140-144

Sellars, R. W., 230

Sense-impressions, in relation to reality, 224-227

Sequence, in relation to causation, 240 
Sex, chromosome, 205; control, 209; determination, 204-210; in lower organisms, 254

Sex-linked heredity, 208

Ships, 20

Shull, A. F., 209

Signatures, Doctrine of, 50

Skepticism, 74, 113, 302-308; and indecision, 302, 304; and toleration, 303, 304; and persecution, 303; during Renaissance, 76-77; growth of, 90 ; in politico-economic field, 303

Skin gland of frog, 147

Slavery, 45

Slocum, S. E., 23

Smallpox, 101, 151

Smith, Adam, 165

Smith, Elliott, 18

Smith, E. A., 171

Smith, Wm., 174

Social, phenomena in light of evolution, 311-312; progress as influenced by science, 269 ; reorganization ineident to Industrial Revolution, 105; sciences, 94, 96

Soil exhaustion, 45

Solutions, 97

Sorbonne, 163

Spallanzani, 100, 123, 189, 191

Sparta, 28

Species, 88, 98

Spectacles, 62

Spencer, Herbert, 177, 178, 263

Spermatists, 189

Spermatozoön, 122, 127, 129, 247

Spinoza, 74

Spinning jenny, Hargreave's, 105

Spiritual values of science, $4,9,114$ 115,290 ; see also Science and Scientific

Split-wheat, 22

Spontaneous generation, 33, 85, 100 , $123-124,151,160,248,249$

St. Ambrose, 46

St. Hilaire, 172

Stahl, 72, 97

St. Augustine, 53

Stahl, 72, 97

Standard measures, 23

Steam engine, $35,62,105$

Steam locomotive, 105

Steamboat, 105

Steamship, 62

Stephen, Leslie, 111, 292

Stevinus of Bruges, 72

Stimulus to development, 192

Struggle for existence, 40,181
Subjective reality, 224, 237

Sumerians, 22

Superman, 206, 317

Supernaturalism, and naturalism 91 , $110,267,312$

Superstition, 40, 75; see also Tradition

Surgery, 151, 152

Surveying instruments, 57

Survival of Fittest, 33, 160, 181

Suspension bridge, 62

Swammerdam, 73, 85

Sylvester Giraldus, 61

Symonds, J. A., 53, 77, 92

Synesius, 48

Taxonomy, see Classification

Taylor, H. O., 21, 24, 38, 43, 52, 63, 64

Telescope, 62

Temptation of Eve, 25

Theology, and religion, present status, 8 ; in light of evolution, $310-311$; in relation to philosophy, 74; see also Religion

"Theoria Generationis," 164

Theory and practice, 231, 236, 242$243,248-250,256,258,261-262$

Thing-in-itself, 225

Thinker 2 's, demagogue, 272

Thomas Aquinas, 64, 76, 110

Thomas of Cantimpré, 85, 86

"Thought-fossils," 159

Tickner, F. W., 105

Tiryns, 26

Toleration, 56, 74, 94, 103, 114, $303-305,307$

Toleration Act, 305

Torricelli, 89

Toscanelli, 71

Towns, 26

Tradition, $74,270-275,280,282$, 299-302; see also Authority and Scriptures

Transmutation, 99

Transmutationists, 162-167

Trinity, 46

Truth, in science, 240-241; and human freedom, 308

Turks, 59

Tyler, H. W., 23, 31, 32

Tyndall, 248

Uhlhorn, G., 43, 44, 47

Unconformity, 176

Uniformitarians, 176

Unit-characters, 140, 197

Universe, see Cosmos 
Universities, $35,55,68,88,89$

Urban life, 45

Use and disuse, 169

Utopia, 264

Vaccination, 101, 151

Vaccines, 150

Valla, 82

Variation, 181; and heredity, as cell problems, 145; inheritance of, 164

Veblen, T., 295

Verworn, M., 148

Vesalius, 73,84

Vespucci, 71

Vested rights, 278

"Vestiges of Creation," 177

da Vinci, see Leonardo

Virchow, 189

Vitalism, 211-213

Voltaire, 113, 114

Voyages of discovery, 39

"Voyage of the Beagle," Darwin, 173,178

Wallace, A. R., 178, 179

Wallace's chart, 180-181

Water frame, Arkwright's, 105

Watson, J. A. S., 185

Watt's steam engine, 105

Weaving industry, 105

Weismann, A., 145, 197
Wells, H. G., 265, 292

Western culture, controlling idea of, 288

Whetham, W. C. D., and C. D., 23, $29,64,79,296$

White, A. D., 48, 61, 63, 161

Whitney, D. D., 209

William of Occam, 64

Wilson, E. B., 120, 195, 203

von Winiwater, H., 207

Wireless message, 295

Wolff, K., 164

"Wonderful Century," 20

Wordsworth, 293.

Worker, modern industrial, his outlook, 5

Wright, J., 159

"X"-chromosome, see Sex-chromosome

Xenophanes, 159

Zoölogical, gardens, 36, 85-87; science, recent developments of, 187

Zoölogy, and experimentation, 187, $195,197,208,214$; and the social sciences, 219 ; in relation to other sciences, 217

"Zoönomia," 166 






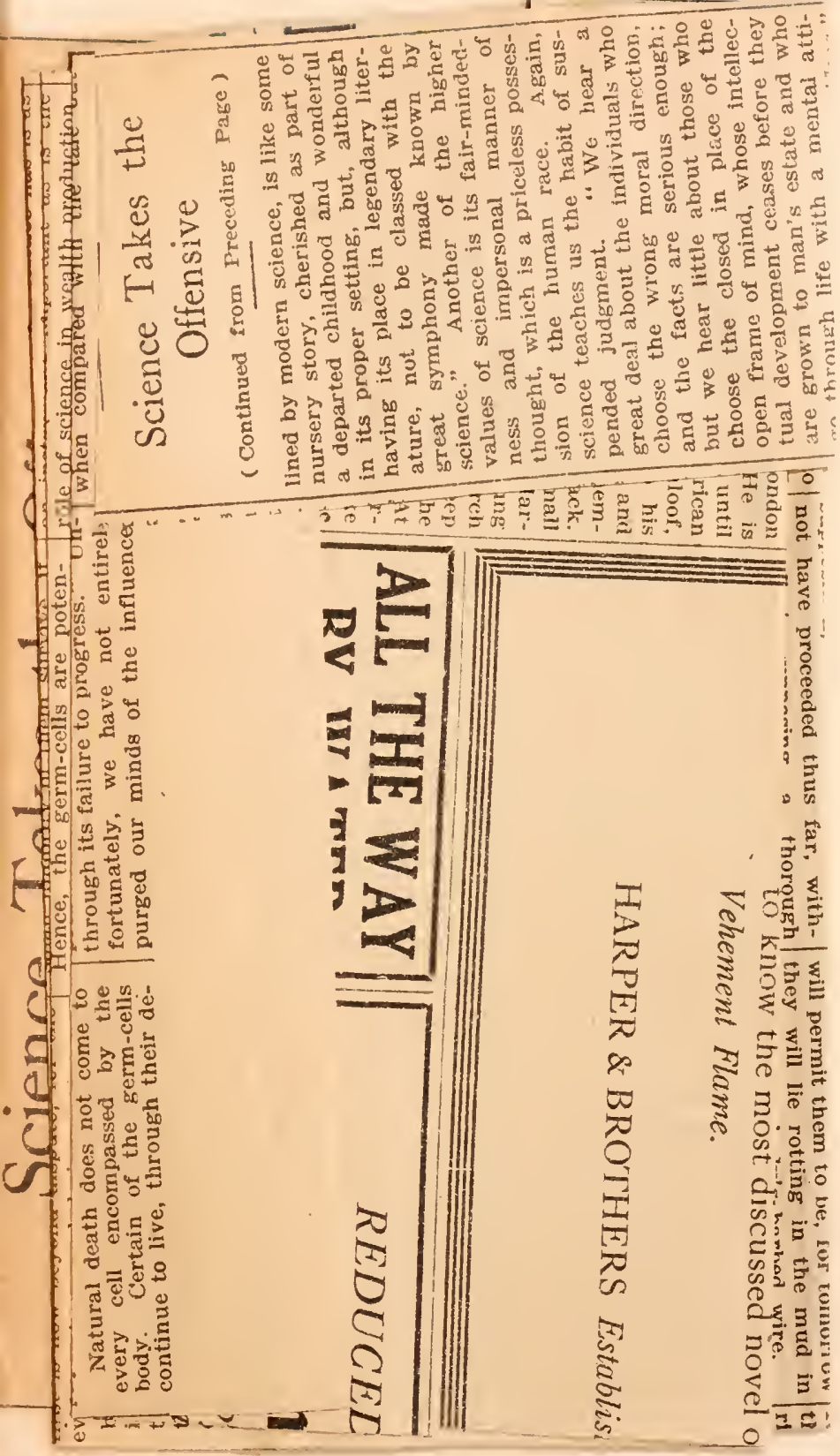


